\title{
Abstracted Publications \\ Related to the Hanford \\ Environment, 1980 to 1988
}

\author{
C. D. Becker \\ R. H. Gray
}

May 1989

Prepared for thie U.S. Department of Energy under Contract DE-AC06-76RLO 1830

Pacific Northwest Laboratory Operated for the U.S. Department of Energy

by Battelle Memorial Institute

\section{Battelle}




\title{
DISCLAIMER
}

This program was prepared as an account of work sponsored by an agency of the United States Government. Neither the United States Government nor any agency thereof, nor Battelle Memorial Institute, nor any of their employees, makes any warranty, express or implied, or assumes any legal liability or responsibility for the accuracy, completeness, or usefulness of any information, apparatus, product, or process disclosed, or represents that its use would not infringe privately owned rights. Reference herein to any specific commerical product, process, or service by trade name, trademark, manufacturer, or otherwise, does not necessarily constitute or imply its endorsement, recommendation, or favoring by the United States Government or any agency thereof, or BattelleMemorial Institute. The views and opinions of authors expressed herein do not necessarily state or reflect those of the United States Government or any agency thereof.

\section{PACIFIC NORTHWEST LABORATORY operated by BATTELLE MEMORIAL INSTITUTE for the UNITED STATES DEPARTMENT OF ENERGY under Contract DE-ACO6-76RLO 1830}

\author{
Printed in the United States of America \\ Available from \\ National Technical Information Service \\ United States Department of Commerce \\ 5285 Port Royal Road \\ Springfield, Virginia 22161 \\ NTIS Price Codes \\ Microfiche A01 \\ Printed Copy
}

$\begin{array}{cc}\text { Pages } & \begin{array}{c}\text { Price } \\ \text { Codes }\end{array} \\ 001-025 & \text { A02 } \\ 026-050 & \text { A03 } \\ 051-075 & \text { A04 } \\ 076100 & \text { A05 } \\ 101-125 & \text { A06 } \\ 126-150 & \text { A07 } \\ 151-175 & \text { A08 } \\ 176200 & \text { A09 } \\ 201-225 & \text { A10 } \\ 226-250 & \text { A1I } \\ 251-275 & \text { A12 } \\ 276300 & \text { A13 }\end{array}$


PNL-6905

UC-11

ABSTRACTED PUBLICATIONS

RELATED TO THE HANFORD ENVIRONMENT, 1980 TO 1988

C. D. Becker

R. H. Gray

May 1989

Prepared for the

U.S. Department of Energy under Contract DE-AC06-76RLO 1830

Pacific Northwest Laboratory

Richland, Washington 99352 


\section{ABSTRACT}

This abstracted bibliography provides a reference to the diverse environmental activities conducted on the Hanford Site from 1980 through 1988. It includes 500 reports and articles that were prepared largely by onsite contractors and the Department of Energy. Documents contained herein were separated into eight subject areas: air and atmosphere, aquatic ecology, effluents and wastes, geology and hydrology, Hanford Site, radioactivity, terrestrial ecology, and socioeconomics. These areas form the basis of a key word index, which is intended to help the reader locate subjects of interest. An author index is also included. 


\section{SUMMARY}

The purpose of this document is to provide the U. S. Department of Energy (DOE), federal and state officials, onsite research staff, and the offsite public with a convenient source of reference to the environmental studies conducted on the Hanford Site from 1980 to 1988 . Compilation of this bibliography was supported by the DOE through the Office of the Hanford Environment, Pacific Northwest Laboratory.

Perhaps nowhere else in the world has an area been environmentally characterized as intensively as the Hanford Site. Characterization studies result directly from Hanford's long-standing role (the "original") as a national center for defense material production and for energy research and development. Over the years, many studies have been conducted at Hanford in response to regulations designed to promote environmental protection and mitigation. Environmental studies intensified during the 1980's, a period over which significant changes in policy and direction took place at Hanford.

F:om 1980 to 1988 , activities sponsored by the DOE at Hanford shifted primarily from production of defense materials to the inventory, treatment, and disposal of accumulated radioactive wastes. Environmental investigations under way before 1980 led to more in-depth studies for the Basalt Waste Isolation Project (BWIP). Work on BWIP terminated in mid-1987 after Hanford was removed from further consideration as a possible site for the Nation's first geological repository for radioactive wastes.

Many studies from 1980 to 1988 focused on developing methods to isolate and treat accumulated radioactive and nonradioactive wastes. Included were new processes to reduce contaminants in liquid effluents, construction of barriers over inactive waste sites, in situ vitrification of near-surface waste, encapsulation of waste as cementous grout material, and resolution of problems related to underground storage tanks. These efforts were accompanied by continued environmentdl monitoring, ecological characterization of onsite plants and animals, new inventories of accumulated wastes, studies of radionuclide fixation and movement in onsite soils, geohydrologic characterization of water movement, and other studies related to the long-term management of wastes at Hanford. In addition, numerous studies were conducted to evaluate the environmental effects of onsite operations, either those under way or those under consideration.

About 500 reports and articles on the Hanford environment were abstracted for this bibliography. The word "environment" covers many interrelated features of the 
biosphere. Thus, the scope of coverage is large. To aid the reader in search of specific topics, eight subject areas were selected as the basis for a key word index:

air and atmosphere

aquatic ecology

effluents and wastes

geology and hydrology
Hanford Site

radioactivity

terrestrial ecology

socioeconomics.

This bibliography represents a comprehensive coverage of information related to the Hanford environment. Generally, monthly and quarterly progress reports were omitted, as were presentations published only as abstracts and lacking detail. Articles submitted for publication in journals and symposia, which may take a year or more to be printed, were omitted if still unpublished at the end of 1988. In addition, some published articles or reports could not be located, and so were not included.

\section{BACKGROUND INFORMATION}

Publications.related to the Hanford environment should be evaluated in relation to the times and sociopolitical events affecting operations on the Hanford Site. Helpful information includes a brief description of the site, a summary of past waste-disposal practices, a listing of significant recent events, and a review of the roles and contributions of onsite contractors.

\section{Hanford Site Environment}

The Hanford Site is located in a rural region of southeastern Washington and occupies 560 square miles. It lies about 320 km northeast of Portland, Oregon, 270 $\mathrm{km}$ southeast of Seattle, Washington, and $200 \mathrm{~km}$ southwest of Spokane, Washington. The Columbia River flows through the northern end of the Hanford Site and forms part of the eastern boundary. The southern boundary of the Site includes the Rattlesnake Hills, which exceed $1100 \mathrm{~m}$ in elevation. Both confined and unconfined aquifers are present beneath the Hanford Site. The main geologic units are the Columbia River Basalt Group, the Ringold Formation, and a series of glaciofluvial sediments. The site is semiarid, and inhabited by desert-steppe plants and animals.

Operations on the Hanford Site are concerned primarily with national defense, and public access to the Site has been restricted since 1943. For management purposes, the site is divided into several operational areas. Several 100 Areas are distributed along the northern margin of the Site adjacent to the Columbia River; they 
contain the widely separated, single-purpose reactors (now shut down) and the dualpurpose N Reactor (now on cold standby). The 200 Areas (Separations Area) are on a low plateau near the center of the site; they contain the fuel reprocessing facilities and the main disposal and storage areas for radioactive and hazardous wastes. The 300 Area lies just north of Richland; it contains metal testing, nuclear fuel fabrication (now on standby), and research and engineering facilities. The 400 Area, between the 200 and 300 areas, is the location of the Fast Flux Test Facility (FFTF). The 3000 Area north of Richland contains facilities owned and operated by Pacific Northwest Laboratory. The 700 Area, north of Richland, contains federal administrative offices.

Portions of the Hanford Site are leased. The Washington Nuclear Project No. 1, 2, and 4 sites, adjacent to the Columbia River in the 400 Area, are controlled by the Washington Public Power Supply System (Supply System). A commercial, low-level radioactive waste disposal site is operated by US Ecology on 100 acres near the center of the Hanford Site under lease from the State of Washington. Land north of the Columbia River on the Hanford Site forms the Saddle Mountain National Wildlife Refuge and the Washington State Department of Wildlife's Wahluke Slope Wildlife Recreation Area.

Parts of the Hanford Site not involved in the production of defense materials serve as a National Environmental Research Park (NERP). More than $193 \mathrm{~km}^{2}$ of the NERP on the northeastern slope of Rattlesnake Mountain is in the Arid Lands Ecology (ALE) Reserve. The ALE Reserve, under restricted public access as part of the Hanford Site, has been protected from all human activity for the past 20 years to allow the conduct of ecological studies on lands remaining in a near-natural state. The Hanford Reach, the last flowing stretch of the mainstem Columbia River below the Canadian border, remains in a relatively pristine condition and is now under consideration as a Wild and Scenic River.

\section{Waste Disposal Practices}

Many environmental studies on the Hanford Site are related to past waste disposal practices. For more than 40 years, nuclear activities at Hanford have resulted in the production of large volumes of liquid and solid wastes. Considerable amounts of waste water containing radioactive materials have been discharged to the ground through cribs, ditches, and ponds. Discharge of waste water began at Hanford in the mid-1940's and peaked in 1955. After 1955, discharges to cribs declined as the treatment of waste streams improved and various facilities involved in producing 
plutonium were upgraded or shut down. The last single-purpose reactor at Hanford was closed in January 1971. The dual-purpose N Reactor, in operation since 1963, was directed in early 1988 to be placed in cold standby.

Generally, subsurface structures on the Hanford Site, such as cribs and tanks, were used for disposal of liquids containing radioactive wastes, while surface ponds and ditches were used to dispose of cooling water and low levels of radioactive wastes. Sanitary wastes were discharged to the ground via tile fields. The majority of liquid waste disposal in the 1980's occurred in the 200 East and 200 West areas. Smaller amounts of waste water have been disposed at the $100 \mathrm{~N}$ Area, and some waste has been placed in a trench in the 300 Area. Discharges of waste water in the 400 Area, where the FFTF and WNP-2 are located, has been minimal.

When large amounts of contaminated liquids are discharged to the ground, they percolate through the unsaturated soil of the vadose zone toward the water table. Annual precipitation in the arid climate at Hanford is generally insufficient to affect this movement. As the liquids pass downward, adsorption to soil particles, chemical precipitation, and ion exchange delay the movement of uncomplexed radionuclides, such as ${ }^{90} \mathrm{Sr},{ }^{137} \mathrm{Cs}$, and $239,240 \mathrm{Pu}$. A few ions, such as nitrate $\left(\mathrm{NO}_{3}\right)$, and a few radionuclides, such as tritium, ${ }^{129}$, and ${ }^{99} \mathrm{Tc}$, are not retained as readily by soil and move through the vadose zone at varying rates. If the mobile contaminants reach the water table, they generally move with the ground water but are attenuated by spreading (dispersion) and radioactive decay.

Today, the defense facilities expected to continue operation until the mid-1990's include the Plutonium Uranium Extraction (PUREX) Plant, where spent fuel from $\mathrm{N}$ Reactor is separated into plutonium, uranium and waste; the Uranium Oxide $\left(\mathrm{UO}_{3}\right)$ Plant, which processes the uranium into $\mathrm{UO}_{3}$ powder; and the Plutonium Finishing Plant, where plutonium is prepared for shipment offsite. The WNP-2, a commercial power reactor, and the FFTF, a facility for advanced reactor development and testing, are also expected to continue operating.

Waste disposal activities at Hanford have been accompanied by extensive environmental surveillance programs. From 1946 to 1957, results of surveillance activities were recorded in quarterly reports; since 1958, these results have been made publicly available as annual reports, with ground-water monitoring reports beginning in 1956. Results in recent years (through 1984) were published as separate reports under the following titles: 
1. Environmental Surveillance at Hanford for the Calendar Year (results of monitoring for offsite areas)

2. Environmental Status of the Hanford Site for Calender Year (results of monitoring for onsite areas, discontinued in 1984)

3. Ground-Water Monitoring at the Hanford Site for Calender Year (results of monitoring for onsite surface areas; discontinued in 1984).

Beginning in 1985, these three reports were combined into one document that summarized all monitoring data collected each calendar year. Most recently, the title, format, and scope of the 1988 environmental monitoring report (Hanford Site Environmental Report for Calendar Year 1988) was changed to reflect new guidance contained in DOE Order 5400.1.

\section{SIGNIFICANT RECENT EVENTS}

From 1980 to 1987, eight companies operated under contract to the DOE-RL on the Hanford Site. These companies and their primary responsibilities were Battelle Memorial Institute, management of DOE's Pacific Northwest Laboratory (PNL); Boeing Computer Services, Richland, Inc. (BCSR), automatic data processing services; Hanford Environmental Health Foundation (HEHF), health services; J. A. Jones Construction Services (JAJ), onsite construction services; Kaiser Engineers Hanford (KEH), onsite architect and engineering services; Rockwell Hanford Operations (Rockwell), chemical processing, waste management, and support services; UNC Nuclear Industries (UNC), management of $\mathrm{N}$ Reactor and its fuel fabrication; and Westinghouse Hanford Company (WHC), management of Hanford Engineering Development Laboratory, and the Fast Flux Test Facility and its fuel fabrication.

In early 1987, the work force at Hanford was consolidated under four contractors. Kaiser Engineers began work in February as DOE's consolidated Architect/Engineer contractor. Westinghouse Hanford Company assumed responsibility in June as the consolidated Operations-Engineering contractor. Battelle Memorial Institute remained as the Research and Development contractor. The Hanford Environmental Health Foundation remained as Health-Care Services contractor. 
The Basalt Waste Isolation Project (BWIP), which developed over the early 1980 's and terminated at the end of 1987, involved characterization of a site in the 200 Areas to see if Hanford would be an acceptable place to permanently store commercial nuclear waste. A draft Environmental Assessment for the Hanford Site as a Reference Repository Location was issued in December 1984. However, Congress amended the Nuclear Waste Policy Act in 1987 so that only one site, in Nevada, would be studied as a possible location for the repository. Virtually all studies involving BWIP ended by 1988.

An accelerated effort to upgrade safety systems at the $\mathrm{N}$ Reactor began in early 1987. However, the defense mission at Hanford was curtailed in early 1988, when DOE placed the $\mathrm{N}$ Reactor on cold standby. A scaled-down defense mission is expected to continue for several years while the $\mathrm{N}$ Reactor is defueled and existing plutonium and uranium are further refined and prepared for shipment.

A final EIS on Hanford's defense wastes was issued in December 1987. This EIS presented a preferred alternative for the safe, permanent disposal of wastes that were generated and stored on the Hanford Site since the 1940's. The states of Washington and Oregon and the DOE reached agreement to form a consensus disposal plan.

The preferred alternative in the EIS for onsite defense wastes recommended two disposal technologies originally developed at Hanford. High-level radioactive wastes, now stored in double-shell tanks, will be processed into glass at the planned Hanford Waste Vitrification Plant (HWVP), then placed in a deep underground repository. Low-level tank waste will be processed into a cement-like grout and allowed to harden in environmentally safe vaults. The vaults will be covered with a protective barrier to prevent intrusion by water, plants, animals, or humans.

\section{CONTRIBUTIONS OF HANFORD SITE CONTRACTORS}

Most publications related to the Hanford Site environment from 1980 to 1988 were produced by the DOE and its onsite contractors. Contributions of the DOE, the specific contractors (including some former contractors), and their involvement in environmental activities on the Hanford Site are identified below. 


\section{U.S. Department of Enerav (DOE)}

The DOE Richland Operations Office is responsible for managing Hanford Site activities. Hanford is a continuing, multiprogram operation in which direction and emphasis change with time. In the 1980's, onsite activities included defense programs, advanced reactor research, radioactive and hazardous waste management, energy conservation, and research in biomedical, environmental, energy, molecular, and life sciences. The DOE currently employs four contractors to manage various parts of this work.

The DOE publishes documents concerning the Hanford Site environment, supports the development of environmental impact statements for new projects as required by law, and actively participates in the development of planning documents.

The DOE and its predecessors, the Atomic Energy Commission (1946 to 1974) and the Energy Research and Development Administration (1975 to 1977) strongly support monitoring and other environmental studies at Hanford. Results of environmental monitoring were recorded in quarterly reports since 1946. Reports on ground-water monitoring began in 1956. The results of all environmental monitoring efforts have been available to the public as annual reports since 1958. Today, monitoring data provide the basis to assess onsite and offsite environmental effects, to determine compliance with pertinent regulations, and to evaluate the near-term adequacy of onsite waste management practices.

\section{Pacific Northwest Laboratorv (PNL)}

Environmental monitoring on the Hanford Site and some offsite areas has been conducted since 1965 by Battelle Memorial Institute as part of its contract to operate PNL for the DOE. The extent of chemical wastes on the Hanford Site, in ground water, and reaching the Columbia River are included in today's monitoring effort.

PNL produces and issues an annual environmental monitoring report for the DOE. PNL staff members also publish studies relating to ecological research on the ALE Reserve, the NERP, and the Hanford Reach of the Columbia River. They contribute to assessment and environmental characterization efforts on the Hanford Site for ongoing and planned programs. PNL also conducts climatological, meteorological, and geohydrological studies on the Hanford Site. 
Rockwell Hanford Operations (Rockwell)

Environmental surveillance in the 200 Areas at Hanford was conducted by Rockwell from 1978 to 1987 . Surveillance involved sampling and analyzing ambient air, surface water, ground water, sediments, soil, and biota. External radiation was measured, and radioactivity was surveyed at waste disposal sites, radiological control areas, and roads. Rockwell also monitored the retired radioactive dry waste disposal sites in the 600 Area.

As part of its surveillance program, Rockwell established environmental protection guides and used administrative control limits to restrict radionuclide emissions. These limits were lower than applicable regulatory limits, and were based on the DOE requirement of keeping radiation exposures to workers (and thereby the public) As Low As Reasonably Achievable (ALARA). With the consolidation of contractors at Hanford in early 1987, surveillance in the 200 Areas was assigned to Westinghouse Hanford Company (WHC).

Rockwell issued annual surveillance reports of the 200 Areas. Rockwell scientists and engineers also contributed to assessment and site characterization studies in the 200 Areas.

\section{UNC Nuclear Industries. Inc. (UNC)}

UNC conducted the environmental surveillance program in the 100 Areas until 1987, when WHC assumed responsibility. UNC evaluated the environmental impact of the $100 \mathrm{~N}$ Reactor, the shutdown single-purpose reactors, burial grounds in the retired 100 Areas, and related facilities. The main objectives of this effort were to monitor radionuclide concentrations in release and transfer pathways, maintain a data base for trend analysis, and demonstrate compliance with applicable regulations.

Ambient air, ground water, vegetation, soil, and sediment were analyzed from the $100 \mathrm{~N}$ Area. Direct radiation was measured around the $1301 \mathrm{~N}$ trench and along the river shoreline. Soil and vegetation were also analyzed from the retired 100 Areas.

UNC produced annual surveillance reports on the 100 Areas, and special reports providing environmental data at waste disposal sites in the 100 Areas.

Westinahouse Hanford Companv (WHC)

As Operations and Engineering contractor since 1987, WHC now conducts the environmental monitoring programs in the $100,200,300$, and 400 areas dealing with 
contamination of air, soil, vegetation, surface water, and ground water from onsite activities, and with levels of external radiation. Radionuclide concentrations are compared with WHC operating limits and with DOE guidelines. WHC has been a contractor at Hanford since 1970, but its role expanded greatly in 1987 when it assumed the Operations and Engineering contract, which consolidated activities previously done by four contractors.

Today, WHC manages activities at two nuclear reactors, the N Reactor and the FFTF. WHC is also responsible for management and cleanup of toxic and radioactive wastes from over 40 years of reactor operations. Support activities managed by WHC include fuel fabrication, chemical processing and decontamination, and decommissioning of old facilities. WHC also manages onsite services such as security, fire protection, transportation, and purchasing.

The annual environmental surveillance reports for the 100, 200, and 300 areas are now issued by WHC. Westinghouse also issues reports on conditions at waste storage sites and plans for future remedial actions or cleanup.

\section{Washinaton Public Power Supply Svstem (Supply System)}

The Supply System was formed to enable state public utilities to cooperatively finance, build, and operate power generating facilities. It leases land on the Hanford Site to operate WNP-2, a 1,100-megawatt boiling water reactor, and the HGP, an 860megawatt facility that produced electricity for over 20 years with steam from $\mathrm{N}$ Reactor. A second nuclear reactor near WNP-2, the 63\% complete WNP-1, is in extended construction delay while another nuclear reactor construction project, near the same location, was terminated in 1982 . The Supply System issues annual environmental operating reports for WNP-2, and supports specific environmental studies in the Hanford Reach near WNP-1 and HGP.

\section{Hanford Environmental Health Foundation (HEHF)}

The HEHF provides personal protection services for the DOE and its contractors in occupational medicine, psychology, and environmental health. It monitors the quality of sanitary water on the Hanford Site, focusing on chemical and microbiological quality; PNL assists by assessing radiological quality. The primary purpose of this monitoring is to protect the health of people consuming ground water and river water. HEHF also conducts nonradiological air monitoring. HEHF issues annual reports on drinking water quality for the Hanford Site. 


\section{DOCUMENT SOURCES}

Publications abstracted in this report include: 1 ) articles written and published in peer reviewed, scientific journals; 2) articles published in symposia proceedings after presentation and peer review; 3 ) technical reports prepared by onsite contractors for the DOE; 4) technical reports prepared for other onsite contractors, and for state and federal agencies; and 5) reports prepared by the DOE. Articles appear in the "open literature" under unlimited distribution, while reports appear in the "gray literature" under limited distribution.

Procedures for obtaining copies of publications in the open literature and gray literature differ according to their source and availability:

\section{Open Literature Documents}

Reprints of articles published in scientific journals or in scientific symposia proceedings are usually available from the senior authors. The name and address of the author or coauthors appear with most articles. Only a card, letter, or phoned request for a reprint is needed. However, considerable time often passes between presentation at a meeting and publication of the peer-reviewed article. In many cases, only abstracts are published and not the entire presentation. Supplies of reprints available to the author may soon be exhausted.

Journals and symposia proceedings are available at most offsite university or college libraries. Some journals are available onsite in the Hanford Technical Library, 3760 Building, and the Life Sciences Library, 331 Building, in the 300 Area at Hanford. Onsite workers can make copies on photocopy machines (subject to copyright restrictions), but work order numbers may be required to cover page costs.

\section{Grav Literature Documents}

Generally, technical reports prepared by Hanford Site scientists and engineers are printed only in limited quantities and have specific but limited distribution. Copies of most documents published by the DOE are available in the Public Reading Room, Federal Building, DOE Richland Operations Office. Here, documents can be reviewed or copied at cost. Some DOE publications related to Hanford are printed by the U.S. Government Printing Office, Washington, D.C. and may be obtained directly from the GPO. 
Nearly all technical reports prepared by Pacific Northwest Laboratory (PNL) under government sponsorship are available to the public at cost from the National Technical Information Service (NTIS, 5285 Port Royal Road, Springfield, Virginia 22161). Technical reports prepared by PNL for private clients are the property of the client; depending on the client's policy, these reports may not be available for public distribution. Documents known to be unavailable to the public were not included in this bibliography.

Copies of technical reports produced on the Hanford Site by operating contractors are also archived and placed on permanent file at the Hanford Technical Library. Copies can be requested from "Technical Files" at a standard fee for each photocopied page. Written requests, along with full identification of the publication needed, must be sent to Technical Files, Hanford Technical Library (3760 Building, 300 Area, Pacific Northwest Laboratory, Richland, Washington 99352). Staff of onsite contractors can request specific publications by completing a standard form (Request for Technical Information Services and/or Materials) and sending it via plant mail to Technical Files. Staff and other individuals (U.S. citizens) can also visit the Technical Library or Technical Files from 8 am to $\mathbf{4} \mathrm{pm}$, Monday through Friday, and locate or request a copy. (Non-staff must obtain a Visitor's Library Pass from the 3790 Security Building, 300 Area.) Archived reports, particularly the older documents, may only be available on microfiche.

Reports by organizations or individuals offsite are usually published only in limited numbers. Most of these reports are not peer reviewed. They are seldom deposited in libraries and may not be publicly available; those known to be unavailable to the public were not included here. 


\section{ACRONYMS AND ABBREVIATIONS}

$\begin{array}{ll}\text { ALARA } & \text { as low as reasonably achievable } \\ \text { BAT } & \text { best available technology } \\ \text { BWIP } & \text { Basalt Waste Isolation Project } \\ \text { CAA } & \text { Clean Air Act } \\ \text { CERCLA } & \text { Comprehensive Environmental Response, } \\ \text { CWA } & \text { Compensation, and Liability Act } \\ \text { DOE } & \text { Clean Water Act } \\ \text { DOE-RL } & \text { U.S. Department of Energy } \\ \text { EIS } & \text { environmental impact statement } \\ \text { EPA } & \text { U.S. Environmental Protection Agency } \\ \text { FFTF } & \text { Fast Flux Test Facility } \\ \text { HDW } & \text { Hanford Defense Waste } \\ \text { HEHF } & \text { Hanford Environmental Health Foundation } \\ \text { HEMP } & \text { Hanford Environmental Management Program Plan } \\ \text { HLW } & \text { high-level wasie } \\ \text { HWMP } & \text { Hanford Waste Management Plan } \\ \text { HWMTP } & \text { Hanford Waste Management Technology Plan } \\ \text { HWVP } & \text { Hanford Waste Vitrification Plant } \\ \text { LLW } & \text { low-level waste } \\ \text { LWDF } & \text { Liquid Waste Disposal Facility } \\ \text { NEPA } & \text { National Environmental Policy Act of 1969 } \\ \text { NPDES } & \text { National Pollutant Discharge Elimination System } \\ \text { PNL } & \text { Pacific Northwest Laboratory } \\ \text { PUREX } & \text { Plutonium Uranium Extraction (process) } \\ \text { QA } & \text { quality assurance } \\ \text { RACT } & \text { Reasonably Available Control Technology } \\ \text { RCRA } & \text { Resource Conservation and Recovery Act } \\ \text { Rockwell } & \text { Rockwell Hanford Operations } \\ \text { SST } & \text { single-shell tank } \\ \text { TRU } & \text { transuranic (waste) } \\ \text { TSCA } & \text { Toxic Substance Control Act } \\ \text { UNC } & \text { UNC Nuclear Industries } \\ \text { UNI } & \text { United Nuclear Industries } \\ \text { WHC } & \text { Westinghouse Hanford Company } \\ & \end{array}$




\section{CONTENTS}

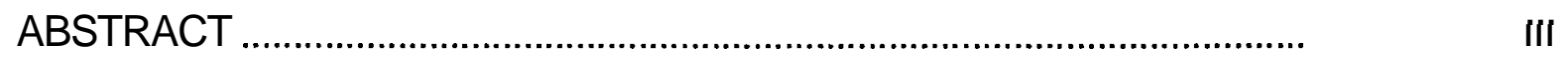

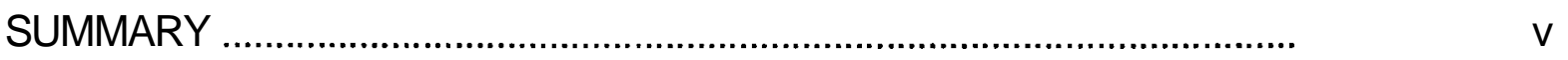

ACRONYMS AND ABBREVIATIONS ....................................................

ABSTRACTED PUBLICATIONS ......................................................

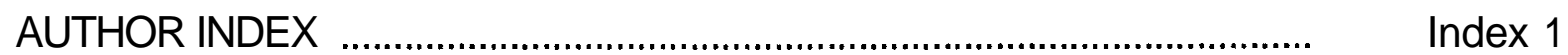

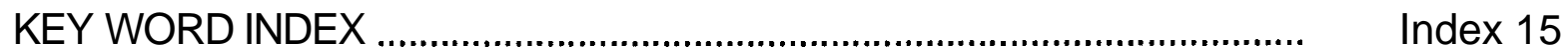




\section{ABSTRACTED PUBLICATIONS}

\section{A-1}

Aaberg, R. L., and B. A. Napier. 1985. Hanford Dose Overview Program: Comparison of AIRDOSEPA and Hanford Site Dose Codes. PNL-5633, Pacific Northwest Laboratory, Richland, Washington. 19 p., App. A and B.

Abstract: Radiation doses for persons in the Hanford area calculated with AIRDOS-EPA were compared with those calculated from several models in use at Hanford: FOOD, PABLM, DACRIN, and KRONIC. Dose commitments to the population and to the maximally exposed individual (MI), based on annual releases of eight radionuclides from the $\mathrm{N}$ Reactor, were calculated by these codes, as were dose commitments via each pathway to the lung, thyroid, lower large intestine, and whole body. In some cases, computed dose estimates disagreed, primarily because of differences in required input data. In general, the Hanford codes produced results that were equivalent to, or more conservative than, AIRDOS.

Key Words: RADIOACTIVITY - AIRDOS model, DACRIN model, FOOD model, KRONIC model, PABLM model, exposure pathways, radiation dose estimates

\section{A-2}

Adams, M. R., R. A. Carlson, and P. K. Brockman. 1981. Long-Term In Situ Disposal Engineering Study. RHO-CD-1142, Rockwell Hanford Operations, Richland, Washington. Irregular pages, App. A through D.

Abstract: This study devised methods, produced conceptual designs, selected alternatives, and estimated costs for long-term (300 years) in situ disposal of an existing waste site. This site was the 216-A-24 crib near the 200 East Area, which contains fission products and has experienced plant, animal, and inadvertent human intrusion. Ground-water flows were modeled to help select a barrier system that will minimize water infiltration and contact time of water with waste. The lifetime and cost of 20 barriers were evaluated, including single component surface barriers, multicomponent barriers, and massive barriers of injected grout.

Five barriers with estimated long effective lifetimes and relatively low costs were evaluated: basalt riprap barriers, massive soil barriers, salt basin barriers, multicomponent fine/coarse barriers, and cemented basalt barriers. A barrier scheme was selected by decision analysis for full-scale demonstration. The basalt riprap barrier at the 216-A-24 crib should be demonstrated as soon as possible. Preliminary designs and costs for applying the five selected barrier schemes to other sites were presented.

Kev Words: EFFLUENTS AND WASTES - barrier systems, radioactive wastes, remedial studies, waste disposal, 200 Areas, 216-A-24 crib

\section{A-3}

Adams, M. R., and M. F. Kaplan. 1986. "Marker Development for Hanford Waste Site Disposal." In Waste Management '86. Proceedings of the Symposium on Waste Management, Vol. 1 General Interest, ed. R. G. Post, pp. 425-431. University of Arizona Press, Tucson, Arizona.

Abstract: An impact statement is being prepared to assess options for disposal of radioactive wastes on the Hanford Site, including in-place stabilization and disposal. Barrier and marker systems are being designed to place over the wastes after site preparation. Archaeological analogues have been examined for guidance in designing markers intended to provide warnings for up to 10,000 years. Materials, dimensions, and messages have been specified for both surface and subsurface markers. A prototype surface marker has been designed and its procurement is pending. Plans for placement of markers are completed.

Kev Words: EFFLUENTS AND WASTES - barrier systems, markers, radioactive wastes, remedial plans, waste disposal 
Albaugh, J. F., J. D. Anderson, and D. R. Groth. 1985.-"Management and Disposal of Hanford Solid Transuranic Waste." In Waste Management '85, Proceedings of the Svmposium on Waste Management, Vol. 1, High-Level Wastes, d. R. G. Post, pp. 199-203. University of Arizona Press, Tucson, Arizona.

Abstract: Solid radioactive waste has been generated at the Hanford Site since 1944. Prior to 1970, this waste was placed in shallow land burial sites. Thereafter, solid waste suspected of being contaminated with transuranic (TRU) materials has been stored so that it is readily retrievable for future processing and/or shipment to a geologic repository. Past, present, and future solid TRU waste activities at Hanford are briefly described.

Kev Words: EFFLUENTS AND WASTES - radioactive waste management, transuranic wastes, waste disposal/treatment

\section{A-5}

Aldrich, R.C. 1984. Liauid Waste Dischareed to Ground in the 200 Areas Through 4th Ouarter 1983 Nonradioloeical Parameters. RHO-HS-SR-83-104Q P, Rockwell Hanford Operations, Richland, Washington. $20 \mathrm{p}$.

Abstract: Nonradiological constituents were examined in 17 effluents from eight facilities in the 200 Areas in 1983. All effluents were in compliance with dangerous waste regulations, except for PUREX process condensate, which was outside $\mathrm{pH}$ limits. Lead has been consistently below the lower level of detection (LLD), even though the method of detection was changed in 4th quarter 1983. Levels of specified heavy metals have been consistently below LLD, and generally less than $25 \%$ of dangerous waste regulations. Total organic carbon was generally below LLD for 12 of 14 liquid effluents. All data were tabulated.

Kev Words: EFFLUENTS AND WASTES - environmental monitoring, hazardous materials, heavy metals, liquid effluents, PUREX Plant, UO, Plant, waste disposal, 200 Areas
Aldrich, R.C. 1984. Radioactive Liauid Wastes Discharged to Ground in the 200 Areas During 1983. RHO-HS-SR-83-3 4QLIQP, Rockwell Hanford Operations, Richland, Washington. 220 p.

Abstract: In 1983, the 200 Areas had 26 liquid discharges, 22 of which were normally or potentially contaminated with radioactive materials. Of these 22 streams, two discharged radioactive material above Table I concentration guides (in DOE Order 5484.1A), and four others discharged material above Table II concentration guides. Effluents exceeding Table I guidelines were B Plant process condensate (plans were made to bring the effluent into compliance) and $\mathrm{AY}$-AZ steam coil condensate, which was shut down after discharging for 3 days. Effluents exceeding Table II guidelines were PUREX process condensate, PUREX ammonia scrubber discharge, $\mathrm{B}$ Plant steam condensate, and $\mathrm{UO}_{3}$ Plant process condensate. The materials involved were ${ }^{90} \mathrm{Sr},{ }^{137} \mathrm{Cs}$, ${ }^{139} \mathrm{Pu}$, and ${ }^{241} \mathrm{Am}$. All six effluents discharged to waste disposal cribs, not to the Hanford environment.

Kev Words: EFFLUENTS AND WASTES - environmental monitoring, liquid effluents,PUREX Plant radioactive materials, $\mathrm{UO}_{3}$ Plant, waste disposal, 200 Areas

\section{A-7}

Aldrich, R. C. 1984. Radioactivitvin Gaseous Waste Discharged from the Separations Facilities During 1983. RHO-HS-SR-83-24Q GAS P, Rockwell Hanford Operations, Richland, Washington. $46 \mathrm{p}$.

Abstract: In 1983, 72 stacks in the 200 Areas discharged gases that were normally or potentially contaminated with radioactive material. The yearly average concentration of two stacks exceeded Table II concentration guide for alpha radiation. All stacks were below the Table II concentration guide for beta radiation, and were below the Table I concentration guide for both alpha and beta. Three stacks released 97\% of the total alpha activity: 291-A-1 (55\%), 291Z-1 (38\%), and 291-T-1 (4\%). The 291-B-1 stack released $69 \%$ of the total beta activity. 
Key Words: EFFLUENTS AND WASTES - environmental monitoring, gaseous emissions, PUREX Plant, radioactivity, waste disposal, 200 Areas

\section{A-8}

Aldrich, R. C. 1985. Liauid Waste Discharged to Ground in the 200 Areas Durine 1984 - Nonradiolegical Parameters. RHO-HS-SR-84-10 4QP, Rockwell Hanford Operations, Richland, Washington. $26 \mathrm{p}$.

Abstract: Nonradiologicalconstituents were examined in 19 liquid effluents from nine facilities in the 200 Areas in 1984. The $\mathrm{pH}$ was below 2.0 in the PUREX process condensate for 3 months, and in the $\mathrm{UO}_{3}$ process condensate for at least 7 months. No specified heavy metal was detected in any process stream. All data were tabulated.

Kev Words: EFFLUENTS AND WASTES - environmental monitoring, hazardous materials, heavy metals, liquid effluents, PUREX Plant, $\mathrm{UO}_{3}$ Plant, waste disposal, 200 Areas

\section{A-9}

Aldrich, R. C. 1985. Radioactive Liauid Wastes Discharged to Ground in the 200 Areas During 1984. RHO-HS-SR-84-34Q LIQ P, Rockwell Hanford Operations, Richland, Washington. 116 p.

Abstract: In 1984, the 200 Areas had 28 liquid discharge streams, two of which were not used. Of these, 22 streams were normally or potentially contaminated with radioactive material. One stream, the PUREX process condensate, exceeded the regulation in DOE (Richland) Order 5820.2 for TRU by 1.9 Limes on an annual average, even though the source was corrected in May. No other streams exceeded any DOE regulations or Rockwell administrative controls. The main sources of alpha-emitting radionuclides were the PUREX process condensate (69\% of total) and the Z Plant waste water (25\%). The main sources of beta-emitting radionuclides were the B Plant process condensate (61\% of total), the PUREX ammonia scrubber (24\%), and the PUREX process condensate $(9 \%)$. The main source of tritium was the PUREX process condensate (93\% of total).
Two new disposal sites were activated in 1984: the 216-S-26 crib and the 216-U-16 crib.

Key Words: EFFLUENTS AND WASTES - environmental monitoring, ground water, liquid effluents, PUREX Plant, radioactivity, waste disposal, 200 Areas

\section{A-10}

Aldrich, R. C. 1986. Radioactive Liauid Wastes Discharged to Ground in the 200 Areas Durine 1985. RHO-HS-SR-85-3-4QLIQ P, Rockwell Hanford Operations, Richland, Washington. $168 \mathrm{p}$.

Abstract: In 1985, the 200 Areas had 28 liquid discharges, other than sanitary sewers, of which 25 were normally or potentially contaminated with radioactive material. Discharge of radioactive liquids to the ground, regulated by DOE Order 5820.2, requires that releases be reduced so radioactivity will not exceed EPA drinking water standards at the point of discharge. In the interim, Rockwell established administrative controls (based on the ALARA concept) that regulate radioactivity to environmentally harmless levels.

Two effluents exceeded Rockwell administrative control values in 1985, the PUREX process condensate and the PUREX ammonia scrubber discharges. In addition, uranium was encountered in ground water below the 216-U-1 and 2 cribs in excess of Rockwell limits. About 30 million liters of ground water containing 0.65 curies of uranium was pumped from the site and cleaned, resulting in a net discharge of negative 0.55 curies of uranium from the 200 Areas in 1985. Most alpha-emitting radionuclides came from PUREX process condensate (56\%) and Z Plant waste water (21\%). Beta-emitting radionuclides came from the PUREX ammonia scrubber (73\%) and B Plant process condensate (9\%). Most tritium (92\%) came from PUREX process condensate.

Kev Words: EFFLUENTS AND WASTES - environmental monitoring, ground water, liquid effluents, PUREX Plant radioactivity, waste disposal, 200 Areas 
Aldrich, R. C. 1987. Radioactive Liquid Wastes Discharged to the Ground in the 200 Areas During 1986. RHO-HS-SR-86-34Q LIQ P, Rockwell Hanford Operations, Richland, Washington. 151 p.

Abstract: Other than sanitary sewers, there were 26 liquid discharges in the 200 Areas during 1986, of which 21 normally or potentially contained radioactive material. Three discharges, the 242-S evaporator cooling water, the $242-S$ process condensate, and the AY-AZ steam coil condensate. The 216-A-25 pond is being decommissioned, with most of its flow diverted to the 216-B-3 pond.

All but two discharges, the PUREX process condensate and the PUREX ammonia scrubber, were in compliance with restrictive Rockwell administrative control values (based on ALARA) in 1986. Most alpha-emitting radionuclides came from PUREX process condensate (59\%) and Z Plant waste water (20\%). Most beta emitting radionuclides came from the PUREX ammonia scrubber (74\%) and the B Plant process condensate $(13 \%)$. Most tritium came from the PUREX process condensate (86\%).

Key Words: EFFLUENTS AND WASTES - environmental monitoring, ground water, liquid effluents, PUREX Plant, radioactivity, waste disposal, 200 Areas

\section{A-12}

Aldrich, R. C., and G. J. Sliger. 1981. Radioactivity in Gaseous Waste Discharged from the Separations Facilities During 1980. RHO-CD-80-354Q, Rockwell Hanford Operations, Richland, Washington. 46 P.

Contents: This report summarizes discharges of radioactive gaseous wastes during 1980 from facilities operated by Rockwell in the 200 Areas. Data on alpha and beta emissions were presented where relevant to the gaseous effluent. Data on emission of gaseous wastes in the 200 Areas by other Hanford contractors were omitted. Total alpha activity consisted largely of ${ }^{239} \mathrm{Pu}$, and total beta activity consisted largely of ${ }^{90} \mathrm{Sr}$, in stack emissions. A summary table lists radioactivity in emissions for 1980, from startup, and decayed from startup.
Kev Words: EFFLUENTS AND WASTES - environmental monitoring, gaseous emissions, hazardous materials, PUREX Plant, radioactivity, 200 Areas

\section{A-13}

Aldrich, R. C., and L. J. Stanfield. 1985. Radioactivity in Gaseous Waste Discharged from the Separalions Facilities During 1984. RHO-HS-SR-84-2-4Q GAS P, Rockwell Hanford Operations, Richland, Washington. $50 \mathrm{p}$.

Abstract: During CY 1984, 77 stacks in the 200 Areas discharged gases that were normally contaminated or potentially contaminated with radioactive material. No emissions were above or even near requirements in DOE Order 5480.1A, Chapter XI. All emissions were below Rockwell administrative controls based on ALARA philosophy.

All of the total alpha activity was discharged by three stacks: 291-A-1 (98\%), 291-Z-1 (1\%), and 291T-1 (1\%). Nearly all of the total particulate beta activity (99\%) was discharged by two stacks: $291-\mathrm{A}$ 1 (98\%) and 291-B-1 (1\%). Results compared releases from the PUREX main stack with Rockwell administrative controls: $1{ }^{95} \mathrm{Kr}$ emissions were $10 \%$ of the control value, 2$)^{239} \mathrm{Pu}$ emissions were $1 \%$ of the control, 3) the sum of releases of all particulate, longlived beta emitters was $0.6 \%$ of the control, and 4 ) the sum of releases of ${ }^{3} \mathrm{H},{ }^{14} \mathrm{C}$, and ${ }^{129} \mathrm{~T}$ was $7 \%$ of the control. Emissions of ${ }^{239} \mathrm{Pu}$ from the T-Plant main stack were $35 \%$ of the control value. All other stack emissions were well below control values.

Kev Words: EFFLUENTS AND WASTES - environmental monitoring, gaseous emissions, hazardous materials, PUREX Plant, radioactivity, 200 Areas

\section{A-14}

Aldrich, R.C., and L. J. Stanfield. 1986. Radioactivitv in Gaseous Waste Discharged from the Separations Facilities During 1985. RHO-HS-SR-85-24Q GAS P, Rockwell Hanford Operations, Richland, Washington. $50 \mathrm{p}$.

Abstract: During CY 1985, 74 stacks discharged gases that were normally contaminated or potentially contaminated with radioactive material. Emissions 
were well below DOE guidelines (DOE Order 5480.1A, Chapter XI) for personal and public exposures (tabulated data). Also, all stacks, except for the PUREX ammonia scrubber discharge (296-A24), were below Rockwell administrative controls based on ALARA philosophy. All of the total alpha activity was discharged by the 291-A-1 (98\%), 291-Z$1(1 \%)$, and 291-T-1 (1\%) stacks. Nearly all of all total particulate beta activity (99\%) was discharged by the 291-A-1 stack. The PUREX ammonia scrubber discharge stack (296-A-24) exceeded the Rockwell administrativecontrol value for ${ }^{106} \mathrm{Ru}$ by $17 \%$. Emission of ${ }^{239} \mathrm{Pu}$ from the T Plant main stack was $5 \%$ of the control value.

DOE-Richland Office Order 5820.2 set a long-term objective of reducing stack emissions to below radioactive concentrationguides for uncontrolled areas unless it is economically impractical to do so. Discharges were below this long-term objective from all but 3 of the 74 stacks: the PUREX main stack (291-A-1), the PUREX ammonia scrubber discharge (296-A-24), and the T Plant main stack (291-T-1).

Kev Words: EFFLUENTS AND WASTES - environmental monitoring, gaseous emissions, hazardous materials, PUREX Plant, radioactivity,200 Areas

\section{A-15}

Allen, R. P., and R. F. Hazelton. 1985. Conversion of Transuranic Waste to Low Level Waste Bv Decontamination - A Site Specific Uddate. PNL-5570, Pacific NorthwestLaboratory,Richland, Washington. 21 p., App. A.

Abstract: Effort was made in 1985 to transfer to DOE sites in the United States (including Hanford) the information and technology for the direct conversion of TRU waste to low-level waste by decontamination. The volume of TRU waste in storage at Hanford as of Dec. 31, 1983 was estimated to be $12,808 \mathrm{~m}^{3}$. The composition of retrievable stored TRU waste at Hanford was reported as 48.7 vol\% metals, 23.3 vol\% combustibles, and the rest as miscellaneous materials.

Kev Words: EFFLUENTS AND WASTES Hanford Site, radioactive waste, transuranic waste
Allison, J. M., and T. B. Bergman. 1988. "The Hanford Grout Treatment Facility - Environmental Assurance in Low-LevelWaste Disposal." In Spectrum ' 88. Proceedings of the International Meeting on Nuclear and Hazardous Waste Management. pp. 130-132. American Nuclear Society, Inc., La Grange Park, Illinois.

Abstract: The grout disposal program at Hanford will develop the technology and facilities to process about $170,000 \mathrm{~m}^{3}$ of low-level liquid radioactive wastes. Its goal is the long-term protection of the public and environment. The final disposal system will provide sufficient isolation to not exceed 1) an annual wholebody dose of $0.25 \mathrm{mSv} / \mathrm{yr}$ to the maximally exposed individual, and 2) primary drinking water standards in ground water at a 5-km well for more than 10,000 years. Waste disposal will meet requirements of the Federal ResourceConservation and Recovery Act (RCRA) and Washington State's Dangerous-Waste Regulations. Preliminary tests show significant mitigation of the hazardous and toxic nature of the waste by immobilization in grout. In addition a unique disposal system is being developed, which includes a reinforced concrete vault, covers, and leaching system; a multilayered protective barrier; and a gravel hydraulic barrier/diffusion break to retard release of radionuclidesand hazardous materials. Disposal of a low-level waste will begin in June 1988. Disposal of higher activity hazardous wastes is scheduled for 1990.

Kev Words: EFFLUENTS AND WASTES - lowlevel wastes, grout treatment facility, radioactive materials, remedial plans, waste disposal

\section{A-17}

Ames, L. L. 1980. Hanford Basalt Flow Mineral= PNL-2847, Pacific Northwest Laboratory, Richland, Washington. $469 \mathrm{p}$.

Abstract: Mineralogy of cores from five wells was examined. The main study included 1) optical examination of polished mounts, photomicrographs, chemical analyses of feldspars, pyroxenes, metallic oxides, and microcrystallinegroundmasses, and 2) determination from chemical analyses of the varieties 
of feldspars, pyroxenes, and metallic oxides. The average primary feldspar was a laboradorite, the average pyroxene was an augite, and the average metallic oxide was a solid solution of ilmenite and magnetite. Secondary mineralization consisted of vug filling and joint coating, chiefly with a nontronite-beidelliteclay, several zeolites, quartz, calcite, and opal.

Specific flow units included the Pomona, the Umatilla, and a high chromium flow just below the Huntzinger. The range of compositional variation of the feldspars was unique in the Umatilla flow. The pyroxenes in the Pomona were relatively highly zoned and accumulated chromium. The high chromium flow contained chromium spinels that graded in content into simple magnetites very low in chromium. Statistically, flow unit constituents were roughly correlated between wells. The probable cause was ongoing physicochemicalchanges in the source magma.

Key Words: GEOLOGY AND HYDROLOGY basalt formations, mineralogy, subsurface characteristics

\section{A-18}

Ames, L. L., and J. E. McGarrah. 1980. High-Temperature Determination of Radionuclide Distribution Coefficientsfor Columbia River Basalts. RHO-BWIC-111, PNL-3250, Rockwell Hanford Operations, Richland, Washington. $24 \mathrm{p}$.

Abstract: Methods are under development to evaluate the effects of temperature and pressure on distribution coefficients $(\mathrm{Kd})$ for radionuclides in basalt. Initial work involved reactions of cesium with basalt at $150^{\circ} \mathrm{C}$ and $300^{\circ} \mathrm{C}$. Cesium $\mathrm{Kd}$ values in basalt decreased with increasing temperature from $23^{\prime \prime}$ to $150^{\circ} \mathrm{C}$, but increased from $150^{\prime \prime}$ to $300^{\circ} \mathrm{C}$. Other radionuclides under investigation include ${ }^{75} \mathrm{Se}$, ${ }^{85} \mathrm{Sr},{ }^{95 \mathrm{~m}} \mathrm{Tc},{ }^{125} \mathrm{I},{ }^{226} \mathrm{Ra},{ }^{235} \mathrm{~Np},{ }^{241} \mathrm{Am}$, and ${ }^{237} \mathrm{Pu}$. Pressure vessels with $300-\mathrm{mL}$ capacity were used for solidliquid containment in the high-temperature experiments. Initial results showed that Kd was reproducible and little affected by increases in pressure from 6.9 to $27.6 \mathrm{MPa}\left(1,000\right.$ to $\left.4,000 \mathrm{lb} / \mathrm{in}^{2}{ }^{2}\right)$.

Kev Words: RADIOACTIVITY - behavior in basalt, cesium-137, distribution coefficients (Kd), effects of pressure, effects of temperature
Ames, L. L., J. A. McGarrah, B. A. Walker, and P. F. Salter. 1982. "Sorption of Uranium and Cesium by Hanford Basalts and Associated Secondary Smectite." Chem. Geol, 35:205-225.

Abstract: Sorption of uranium and cesium was compared in three basalts and an associated secondary smectite. Tests with two synthetic basalt ground waters at $23^{\circ} \mathrm{C}$ and $60^{\circ} \mathrm{C}$ allowed the effects of increased temperature and carbonate concentration on sorption to be compared. Sorption data were fitted to the D-R isotherm, and loading maxima and energetics were derived.

An increase in temperature caused the sorption maxima to decrease for cesium and to increase for uranium on all basalts in all ground waters studied, especially from ground water with the higher carbonate content. Sorption energies were characteristic of ion exchange for both uranium and cesium sorption processes. Basalt uranium sorption maxima were relatively insignificant, but smectite uranium sorption maximum surpassed cesium sorption maxima in both ground waters at $60^{\circ} \mathrm{C}$. Thus, the uranyl carbonate complexes may be relatively sensitive to temperature. When excess Fe-oxides were removed from the srnectite, uranium sorption decreased and the D-R isotherm reverted to a normal Freundlich sorption isotherm. Removal of excess Feoxides from the basalts and smectite would probably result in Freundlich sorption isotherms for both cesium and uranium.

Kev Words: RADIOACTIVITY - adsorption, behavior in basalt, cesium-137, effect of temperature, uranium

\section{A-20}

Ames, L. L., P. F. Salter, J. E. McGarrah, and B. A. Walker. 1984. "Selenate-Selenium Sorption on a Columbia River Basalt (Umtanum Basalt, Washington, U.S.A.)" Chem. Geol. 43:287-302.

Abstract: This study examined selenate-selenium sorption reactions with Umtanum flow basalt, and was a step in assessing the migration potential of selenate-selenium through the basalt geohydrologic system. Sodium selenate and a radioactive tracer, ${ }^{75} \mathrm{Se}$ with a 120-day half-life (present as sodium 
selenate), were used along with a synthetic ground water and crushed Umtanum basalt between $40^{\circ} \mathrm{C}$ and $60^{\circ} \mathrm{C}$. Equations were derived for: a) selenium sorption kinetics under both oxidizing and reducing solutions, and b) selenium desorption kinetics in $60^{\circ}$ Coxidizing systems. Equilibrium results conformed to a Freundlich sorption isotherm. The enthalpy change was independent of temperature. Chemisorption was indicated by the magnitude of enthalpy change. Desorption kinetics at $60^{\circ} \mathrm{C}$ were only modestly less rapid than sorption kinetics, suggesting a relatively small sorption activation energy. Reduced (Eh $=-150$ to $-200 \mathrm{mV}$ ) selenium did not desorb. Results indicate that a proposed highlevel waste repository in basalt at about $1000 \mathrm{~m}$ in depth and a $55^{\prime}$ to $60^{\circ} \mathrm{C}$ temperature would have a greatly retarded potential migration rate for selenateselenium under both oxidizing and reducing conditions.

Kev Words: RADIOACTIVITY - behavior in basalt, ground-water transport, selenium, sorption/desorption

\section{A-21}

Andrews, G. L. 1988. The Hanford Meteorological Data Collection Svstem and Data Base. PNL-6509, Pacific NorthwestLaboratory, Richland, Washington. 17 p., App. A and B.

\begin{abstract}
The current data base includes wind telemetry stations, doppler acoustic sounders (SODAR), 200-ft towers, a 410-ft tower, at the HMS, and surface weather observations at the HMS. Data from the wind telemetry station, 410-ft tower, and surface weather observations are archived into yearly ACSII files, and the others are archived in binary form on magnetic tape. In the future, all data will be permanently archived into yearly ASCII files. Quality assurancecomputer programs will be written to validate the current data base, and a data archival program will be written to improve the archival method now used.
\end{abstract}

Kev Words: AIR AND ATMOSPHERE- archives (records), data base, equipment/facilities, Hanford Site, Hanford Meteorological Station
Andrews, G. L., and J. W. Buck. 1987. Hanford Meteorological Station Computer Codes. Vol. 2 - The PROD ComputerCode. PNL-6279 Vol. 2, Pacific Northwest Laboratory, Richland, Washington. 15 p., App. A and B.

Abstract: At the end of each work shift (day, swing, and graveyard), the HMS issues a "production forecast" of wind speed and direction at the 200-ftlevel, and of current weather conditions for use at B Plant and PUREX. The PROD computer code is used to archive these forecasts and enable quality assurance checks. The code accesses an input file containing the previous forecast's date and shift number, and an output file containing the production forecasts for the current month. A data entry form consisting of 20 fields must be filled in by the user. The information entered is appended to the current production monthly forecast file.

Kev Words: AIR AND ATMOSPHERE - computer program, PROD model, Hanford Meteorological Station, weather observations, wind speed and direction

\section{A-23}

Andrews, G. L., and J. W. Buck. 1987. Hanford Meteorological Station Computer Codes. Vol. 4 - The SUM Computer Code. PNL-6279 Vol. 4, Pacific Northwest Laboratory, Richland, Washington. 15 p., App. A and B.

Abstract: At the end of each swing shift, a set of daily weather observationsis archived at the HMS. The data include a summary of the maximum and minimum temperature, total precipitation, maximum and minimum relative humidity, total snowfall, total snow depth at 1200 Greenwich Mean Time, and maximum wind speed plus wind direction and time of occurrence. The summary also records rain, snow, and other weather phenomena. The SUM computer code is used to archive the summary and enable quality assurance checks. The code accesses an input file containing a daily weather summary for the current month. A data entry form must be filled in by the user. Information entered is appended to the monthly file. 
Kev Words: AIR AND ATMOSPHERE - computer program, Hanford Meteorological Station, SUM model, weather observations

\section{A-24}

Andrews, G. L., and J. W. Buck. 1987. Hanford MeteorologicalStation Computer Codes. Vol. 6 - The SFC Computer Code. PNL-6259 Vol. 6, Pacific Northwest Laboratory, Richland, Washington. 21 p., App. A and B.

Abstract: Weather observations are recorded and archived each hour at the HMS. Observations include weather phenomena such as cloud type and coverage; dry bulb, wet bulb, and dew point temperatures; relative humidity; atmospheric pressure; and wind speed and direction. The SFC computer code is used to archive these weather observations and enable quality assurance checks. The code accesses an input file containing the previous archive's date and hour, and an output file containing surface observations for the current day. A data entry form consisting of 24 fields must be filled in by the user. Information entered is appended to the daily file, which provides an archive for the hourly surface observations.

Key Words: AIR AND ATMOSPHERE- computer program, Hanford Meteorological Station, SFC model, weather observations

\section{A-25}

Andrews, G. L., and J. W. Buck. 1988. Hanford Meteorological Station Computer Codes. Vol. 7 - The RIVER Computer Code. PNL-6279 Vol. 7, Pacific

Northwest Laboratory, Richland, Washington. 11 p., App. A and B.

Abstract: The RIVER computer code is used to archive Columbia River data measured at the $100 \mathrm{~N}$ Reactor. The data are recorded every other hour starting at 0100 Pacific Standard Time (12 per day), and consist of river elevation (feet), temperature $\left({ }^{\circ} \mathrm{C}\right)$, and flow rate (cfs). The program prompts the user for river data by using a data entry form. After data have been entered and verified, the program appends each hour of river data to the end of each corresponding surface observation record for the current day. The appended data are then stored in the current month's surface observation file.
Kev Words: AIR AND ATMOSPHERE- computer program, river flow data, Hanford Meteorological Station, RIVER model, river temperature

A-26

Andrews, G. L.. and J. W. Buck. 1988. Hanford MeteorologicalStation Computer Codes. Volume 8 The REVIEW Computer Code. PNL-6279 Vol. 8, Pacific Northwest Laboratory, Richland, Washington. 18 p., App. A through C.

Abstract: Meteorological data are collected from sources on and off the Hanford Site by the HMS. The data are averaged over both 15 and 60 minutes, and are maintained in separate data bases at the HMS on a VAX 11/750 computer. The databases are transferred to the Emergency Management System (EMS) DEC VAX 11/750 computer. The EMS is part of the Unified Dose Assessment Center in the Federal Building, and operated by PNL. The computer program REVIEW is used to display meteorological data in graphical and alphanumeric form from either the 15-min or hourly data base. The code is available on the HMS and EMS computer. REVIEW helps maintain high-level quality assurance on instruments that collect data, and provides a convenient way to analyze meteorologicaldata and respond to emergency response situations.

Key Words: AIR AND ATMOSPHERE- computer program, Emergency Management System (EMS), Hanford Meteorological Station, REVIEW model, weather observations

\section{A-27}

Arnett, R.C., R.G. Baca, J.A. Caggiano, S.M. Price, R.E. Gephart, and S.E. Logan. 1980. Preliminary Hvdrolovic Release Scenarios for a Candidate Repositorv Site in the Columbia River Basalts. RHOBWI-ST-12, Rockwell Hanford Operations, Richland, Washington. $8 \mathrm{p}$.

Abstract: The National Waste Terminal Storage program is examining a number of rock types for possible use as a repository for radioactive wastes. A feasibility study by Rockwell of basalt under the Hanford Site is under way (BWIP). An initial step was a scenario analysis to select and rank some potentially disruptiveevents or processes. In 
addition to a no-disruptive base case, four disruptive scenarios were selected based on expert opinion and on expected or perceived risk. Ranked in order of decreasing significance, the four scenarios were: 1) a fault near or through the repository,2) a shaft seal degradation or failure, 3) a microearthquake swarm near the repository, and 4) magmatic intrusion.

Kev Words: HANFORD SITE - BWIP site, environmental assessment, planning document, disruptive events

\section{A-28}

Athey, G. F., K. J. Allwine, and J. V. Ramsdell. 1981. User's Guide to the MESOI Diffusion Model and to the Utility Programs Undate and LOGRVU. PNL-3999, Pacific Northwest Laboratory, Richland, Washington. 37 p, App. A.

Contents: MESOI is an interactive, Lagrangian puff trajectory diffusion model used to examine dispersion of gaseous releases. This guide provides users with the information necessary-toconduct model simulations. The first part deals with MESOI, the second with UPDATE and LOGRW. Examples are given for the operation of all three programs, and an appendix documents UPDATE and LUGRVU.

Kev Words: AIR AND ATMOSPHERE- atmospheric dispersion, computer program, LOGRVU model, MESOI model, UPDATE model

\section{B-1}

Backman, G. E., J. T. Denovan, N. P. Nisick, and J. A. Piatt. 1986. A Hazard Classification Method for Facilities Containing Toxic Chemicals at the Pacific Northwest Laboratory. PNL-5764, Pacific Northwest Laboratory, Richland, Washington.

Abstract: Guidelines were provided to determine if the quantity of nonradioactive toxic materials in any PNL or PNL-managed facility constitutes a potential threat to the public or to employees outside the facility. The "Immediately Dangerous to Life or Health" concept developed by the Department of Health, Institute of Occupational Safety and Health, the Occupational Safety and Health Administration, and contractors who work with these organizations were used as a measure to determine potential effects.
The three hazard classes of Low, Moderate, and High defined in DOE Order 5481.1A were used to determine seriousness of potential effects. Management requirements related to hazard classification were included.

Kev Words: EFFLUENTS AND WASTES hazardous materials, hazardous wastes, hazard ranking, hazardous waste management

\section{B-2}

Barnes, J. R., J. V. McArthur, and C. E. Cushing. 1986. "Effect of Excluding Shredders on Leaf Litter Decomposition in Two Streams." Great Basin Nat. 46:204-207.

Abstract: Shredders (aquatic invertebrates) were excluded from leaf processing activities in a Rocky Mt. stream in Utah and a cold desert stream in Washington (RattlesnakeSprings, Hanford Site). Exclusion of shredders significantly decreased the rates at which leaves were converted to fine particulate organic matter in both streams. Processing rates (k) were higher in the desert stream, presumably because microbial activity was increased by the higher water temperatures.

Key Words: AQUATIC ECOLOGY - allochthonous detritus, ecological relations, leaf decomposition

\section{B-3}

Barney, G.S. 1981. "Radionuclide Reactions with Groundwater and Basalts from Columbia River Basalts." RHO-SA-217, Rockwell Hanford Operations, Richland, Washington. $31 \mathrm{p}$.

Abstract: Reactions of radionuclides with geological materials in Columbia River basalt formations were studied to determine how these formations retard movement of radioactivity. Reactions that can influence movement are precipitation,ion-exchange, complexation, and oxidation-reduction. They were studied by measuring the effect of ground-water composition and redox potential (Eh) on radionuclide sorption on fresh basalt surfaces, a naturally altered basalt, and a sample of secondary minerals. In addition,radionuclidesorption and desorption isotherms were measured and reaction kinetics were determined. 
The radionuclides studied were ${ }^{137} \mathrm{Cs}$, ${ }^{\text {sr } 85},{ }^{75} \mathrm{Se}$, ${ }^{95 \mathrm{~m}} \mathrm{Tc},{ }^{\mathrm{N}} 237,{ }^{241} \mathrm{Am},{ }^{226} \mathrm{Ra}$, and ${ }^{237} \mathrm{Pu}$. The Freundlich equation accurately describes the isotherms when radionuclidesdo not precipitate. Sorption and desorption isotherms show a pronounced hysteresis effect for sorption of most radionuclides. In general, sorption increased in ascending order: basalt, altered basalt, and secondary minerals, corresponding to increasing surface area and cation exchange capacity. The Eh of the system had a large effect on sorption of technetium, plutonium, and neptunium. Tc(VII), $\mathrm{Pu}(\mathrm{VI})$, and $\mathrm{Np}(\mathrm{V})$ were reduced to $\mathrm{Tc}(\mathrm{IV}), \mathrm{Pu}(\mathrm{IV})$, and $\mathrm{Np}$ (IV), respectively, under Eh conditions expected in deep basalt formations.

The kinetics of radionuclide sorption and basaltground-water reactions were observed over 18 weeks. Most sorption reactions stabilized after about 4 weeks. Ground-water composition changed the least in contact with altered basalt. Contact with secondary minerals greatly increased concentrationsof calcium, potassium, and magnesium in ground water.

Kev Words: RADIOACTIVITY - behavior in ground water, ion-exchange, physicochemical properties, radionuclides, redox potential(Eh), sorption/desorption

\section{B-4}

Barney, G.S. 1984. "Radionuclide Sorption and Desorption Reactions with Interbed Materials from the Columbia River Basalt Formation." In Geochemical Behavior of Disposed Radioactive Waste, eds. G.S. Barney, J.D. Navratil, and W.W. Schultz, pp. 323. ACS Symposium Series 246, American Chemical Society, Washington,D.C.

Abstract: Radionuclidesof concern in assessing the safety of a high-level waste (HLW) repository were exposed to sandstone and tuff materials from between basalt flows in ground-water interbed systems. Effects of ground-water composition and redox potential (Eh) on radionuclidesorption and desorption of the geologic solids were studied. Sodium, potassium, and calcium in ground water decreased sorption of cesium, strontium, and radium by ion exchange reactions. Ground-water Eh strongly affected sorption of technetium, neptunium, plutonium, and uranium since chemical species of these elements containing lower oxidation states were taken up more extensively by chemisorption than those containing higher oxidation states. No effect of complexation by ground-waterions on sorption was observed, except for neptunium carbonate (or bicarbonate) complexes and plutonium complexes.

The Freundlich equation accurately described most sorption and desorption isotherms under oxidizing and reducing conditions in this study. Most radionuclides are apparently irreversibly sorbed on each of the geologic solids since the slopes of sorption and desorption isotherms for a given radionuclide were different. This hysteresis effect was very large, and will cause a significant delay in ground-water transport of radionuclides.

Kev Words: RADIOACTIVITY - behavior in ground water,ion-exchange,physicochemical properties,radionuclides, redox potential (Eh), sorption/desorption

\section{B-5}

Barney, G. S., and B. J. Wood. 1980. Identification of Kev Radionuclidesin A Nuclear Waste Repository in Basalt. RHO-BWI-ST-9, Rockwell Hanford Operations, Richland, Washington. 29 p.

Abstract: Key radionuclides were identified that potentially pose the greatest hazard during long-term storage of nuclear waste in a repository placed in Columbia River basalt. Criteria used in selection were: 1) quantity of radionuclides in stored waste, 2) biological toxicity, 3) leach rate of wastes into ground water, and 4) transport rate via ground-water flow. Waste forms were assumed to be either unreprocessed spent fuel or borosilicate glass containing reprocessed high-level waste, of a composition created by a light water reactor. The radionuclides were ranked in order of quantity, toxicity, and release rate from the repository. The ten most important, in order of decreasing hazard, were: ${ }^{99} \mathrm{Tc},{ }^{129} \mathrm{I},{ }^{237} \mathrm{~Np},{ }^{226} \mathrm{Ra},{ }^{107} \mathrm{Pd},{ }^{230} \mathrm{Th},{ }^{210} \mathrm{~Pb},{ }^{126} \mathrm{Sn},{ }^{79} \mathrm{Se}$, and ${ }^{242} \mathrm{Pu}$.

Kev Words: HANFORD SITE - BWIP program, geologic repository, radionuclidesfrom BWIP, planning document 
Beak Consultants,Inc. 1980. Preoperational Environmental Monitoring Studies Near WNP-1.2. and 4. August 1978 Throueh March 1980. WPPSS Columbia River Ecological Studies Vol. 7. Report to Washington Public Power Supply System, Richland, Washington. Irregular pages, App. A through J.

Contents: Studies were conducted in the Hanford Reach at the sites of Washington Nuclear Projects (WNP) 1, 2, and 4 to obtain ecological "baseline" data before these three power plants began operation (note: only WNP-2 was completed). This report provides data on phytoplankton, zooplankton, ichthyoplankton (larval fish), benthic macrofauna and microflora, and fish. No apparent interactions were found between fish and the intake structure or the discharge plume of WNP-2. Values for turbidity and suspended solids remained within temporary water quality standards when the intake and discharge lines of WNP-1 and 4 were actually installed.

Kev Words: AQUATIC ECOLOGY - anadromous fish, aquatic organisms, benthic organisms, community structure, Hanford Reach, phytoplankton, WNP2, resident fish, zooplankton

\section{B-7}

Becker, C. D. 1980. "Haematozoa from Resident and AnadromousFishes of the Central Columbia River." Can. J. Zool. 58:356-362.

Abstract: Blood parasites were surveyed in 840 fish from the Hanford Reach, representing 12 families and 34 species. Nine species of fish were parasitized by one or two species of haematozoa. Most infections occurred in suckers (Catostomidae) and sculpins (Cottidae). Intensities of all parasitemias were low, indicating no symptomatic damage to infected hosts. Two piscicolid leeches found attached to fish might transmit the blood parasites.

Kev Words: AQUATIC ECOLOGY - anadromous fish, resident fish, Hanford Reach, fish parasites
Becker, C. D. 1985. Anadromous Salmonids of the Hanford Reach. Columbia River: 1984 Status. PNL5371, Pacific Northwest Laboratory, Richland, Washington. Irregular pages.

Abstract: The flowing Hanford Reach supports spawning populations of anadromous fall chinook salmon and steelhead. It also serves as a migration route for upriver runs of chinook, coho, and sockeye salmon, and of steelhead. Chinook salmon spawners increased dramatically after 1960, when Priest Rapids Dam was completed, then remained relatively stable since 1969. Numbers of adult salmon that traverse the Hanford Reach have varied in recent decades. Generally, upriver runs of spring, summer, and fall chinook salmon are depressed, but the fall run has increased since 1980. Runs of coho salmon fell since 1976, when hatchery production was cut back. Runs of sockeye salmon declined to about 40,000 fish annually after 1968, but surged upward in 1983 and 1984. Upriver runs of steelhead, which also surged upward in 1983 and 1984, resulted from increased hatchery releases.

Habitat modification represents the greatest threat to sustained production of fall chinook salmon in the Hanford Reach. Operations on and near the Hanford Site have negligible effects on salmonids and other aquatic resources. Some offsite activities that might affect fisheries habitat and water quality in the future are identified.

Kev Words: AQUATICECOLOGY - abundance, anadromous fish, chinook salmon, effect of Hanford operation, Hanford Reach

\section{B-9}

Becker, C. D.. D. H. Fickeisen, and J. C. Montgomery. 1981. Assessment of Impacts from Water Level Fluctuations on Fish in the Hanford Reach. Columbia River. PNL-3813, Pacific Northwest Laboratory, Richland, Washington. $53 \mathrm{p}$.

Abstract: Effects of water level fluctuations in the Hanford Reach at three sloughs were examined under high water conditions in 1976 and low water conditions in 1977. Fish were lost primarily by stranding, entrapment (with or without complete dewatering), 
and predation. Juvenile fish were more susceptible than adult fish. Losses could not be estimated quantitatively.

The most valuable species affected were anadromous fall chinook salmon and resident smallmouth bass. Winter, when incubating eggs were in gravel, and spring, when fry were migrating seaward, were crucial times for chinook salmon. Spring and early summer, when adults were spawning in warmed sloughs and shoreline areas, were crucial times for smallmouth bass. Small bass fry were vulnerable to stranding and entrapment, and bass nests were susceptible to exposure and temperature changes. Other species of fish in the Hanford Reach were affected less because they depended less on shoreline areas for spawning and rearing young. Losses in shoreline areas did not appear to affect ecosystem dynamics.

Kev Words: AQUATIC ECOLOGY - anadroinous fish, benthic organisms, Hanford Reach, residentfish, effect of water level fluctuations

\section{B-10}

Bihl, D. E., R. C. Aldrich, and L. J. Stanfield. 1985. Rockwell Hanford Operations Effluents and Solid Waste Burials During Calender Year 1984. RHOHS-SR-84 1 P, Rockwell Hanford Operations, Richland, Washington. 157 p., App. A through C.

Abstract: In 1984, no effluents exceeded applicable DOE limits at the site boundary. One effluent, the PUREX Plant process condensate, exceeded the DOE-Richland limit at the point of discharge for TRUs in liquids by a factor of 1.9; this was corrected in May. Radionuclides in two effluents exceeded Rockwell administrative controls, but not DOE or DOE-Richland limits: the main stack at PUREX plant (for ${ }^{239,240} \mathrm{Pu}$ ) and the B Plant process condensate (for ${ }^{89,90} \mathrm{Sr}$ ); the long-term environmentalimpacts were determined to be negligible. Opacity limits were exceeded 4 days at the 200 West Area powerhouse when the panel controlling operation of the soot filters failed. Instantaneousconcentration limits for $\mathrm{NO}_{x}$ were exceeded three times at the PUREX Plant very briefly; $\mathrm{NO}_{x}$ emissions also exceeded the daily limit once by a factor of 1.1. Instantaneousconcentrations at the UO, plant were briefly exceeded once, and daily limit was exceeded once. Regulatory agents were notified and correctiveactions taken.
Kev Words: EFFLUENTS AND WASTES - environmental monitoring, hazardous materials, PUREX Plant, radioactivity, regulatory compliance, UO, Plant, 200 Areas

\section{B-11}

Blair, S. C., L. S. Law, and J. W. Lindberg. 1981. A Catalog of Borehole Geophysics on the Hanford Site. 1958 to 1980 . PNL-3504, Pacific Northwest Laboratory, Richland, Washington. 104 p., App. A.

Contents: Borehole geophysicsis an important tool for determining subsurface characteristics. This report provides a catalog of physical data from nearly 800 well boreholes on and around the Hanford Site. The cata are placed in a format that can be easily adapted to computerized data management, and wells are identified by maps. Each well is classified according to the amount of geophysical logging data available.

\section{Kev Words: GEOLOGY AND HYDROLOGY -} borehole data (wells), Hanford Site wells, subsurface characteristics

\section{B-12}

Blumer, P. J., M. J. Sula, P. A. Eddy, and R. L. Dirkes. 1982. Master Schedule for CY- 1983 Hanford Environmental Surveillance Routine Sampling Program. PNL-4565, Pacific Northwest Laboratory, Richland, Washington. 49 p., App. A and $\mathrm{B}$.

Contents: This report gives the 1983 schedule for collecting data under the routine environmental surveillance and ground-watermonitoring programs at the Hanford Site. The programs detect, evaluate, and report the levels of radioactive and nonradioactive releases, as required in DOE Order 5484.1. This schedule does not include samples collected to support special studies or provide quality control, and it may be modified when conditions require.

Kev Words: HANFORD SITE - environmental monitoring, sampling schedule 
Bolton, P. A. 1987. Interim Housing Conditions Profile - Benton and Franklin Counties, Washington. BWIP Repository Project, Working Draft. PNL6390 (BHARC-800/87/026), Pacific Northwest Laboratory, Richland, Washington. 29 p.

Contents: This is one of five socioeconomic profile reports produced by BWIP before the effort ended in late 1987. The report provides a general background of housing conditions in the Benton-Franklin metropolitan statistical area (MSA). It compares total housing in 1970 and 1980, changes in housing stock 1980-1986, identifies the demand for housing on the basis of vacancy rates, and summarizes outstanding technical issues and data requirements. A working bibliography is provided.

Key Words: SOCIOECONOMICS - BentonFranklin MSA, effect of BWIP, demography, housing, information needs.

\section{B-14}

Bolton, P. A. 1987. Community Interviews Task Report. BWIP Repository Project. Working Draft. PNL-6383(BHARC-800/87/025), Pacific Northwest Laboratory, Richland, Washington. $11 \mathrm{p}$.

Contents: Community interviewsenable the collection and analysis of data on socioeconomic and sociocultural conditions in Benton and Franklin Counties, Washington. This report gives the objectives of community interviewing, which supports the possible BWIP Reference Repository at Hanford, and identifies the general methods to be used in conducting the interviews. A preliminary list of organizations and agencies from which people could be selected for interviews is given in an appendix. Less than 200 persons will probably be interviewed, with about 45 becoming the mainstay of a socioeconomic monitoring and assessment program.

Kev Words: SOCIOECONOMICS - effect of BWIP, community interviews, data sources, monitoring

\section{B-15}

Booth, G. F., R. C. Aldrich, R. S. Shay, and L. J. Stanfield. 1986. Rockwell Hanford Operations
Effluentsand Solid Waste Burials During Calender Year 1985. RHO-HS-SR-85 1 P, Rockwell Hanford Operations, Richland, Washington. 162 p., App. A throughE.

Abstract: In CY 1985, all liquid and airborne discharges of radioactive materials complied with DOE requirements. The ammonia scrubber stack (296-A24) at the PUREX Plant exceeded Rockwell administrative controls by a factor of 1.17 for ${ }^{106} \mathrm{Ru}$. All other radioactive discharges to the atmosphere were below control values. Two liquid streams exceeded Rockwell con-trols: the PUREX process condensate exceeded the value for ${ }^{239,240} \mathrm{Pu}$ by a factor of 2.7 , and the value for ${ }^{241} \mathrm{Pu}$ by a factor of 1.6. The PUREX ammonia scrubber stream exceeded the ${ }^{89,90} \mathrm{Sr}$ control value by a factor of 3.2. Power plants in the $\mathbf{2 0 0}$ Areas complied with requirements of the BentonFranklin-Walla Walla County Air Pollution Control Authority, and no opacity violations occurred. $\mathrm{NO}_{x}$ emissions from PUREX and the UO, plants were below annual limits.

Kev Words: EFFLUENTS AND WASTES - environmental monitoring, gaseous emissions, liquid effluents, PUREX Plant, radioactivity,UO, Plant, 200 Areas

\section{B-16}

Brooks, G. G. 1985. "Avian Interactions with MidColumbia River Water Level Fluctuations." Northwest Sci. 59:304-312.

Abstract: Fluctuating water levels in the midColumbia River (Hanford Reach), primarily from power generation at hydroelectric dams, create environmental benefits for birds. Ground feeders and water gleaners feed on aquatic organisms stranded on shore and on terrestrial organisms swept into the water. Riparian plants, particularly willows, are slowly invading gently sloping shorelines because daily water level fluctuations frequently moisten soils that were historically dry during summer. These riparian plants provide new nesting and perching sites for passerine birds.

There are also negative features. Daily fluctuations in water levels and erratic spring surges in the Yakima River Delta area inhibit reproduction of birds that nest on the ground along the shoreline, especially waterfowl. Fifty-eight species of birds were listed 
from the Hanford Reach and in the Yakima River Delta between June 1982 and June 1983. These birds were cataloged into six guilds on the basis of feeding behavior.

Key Words: TERRESTRIAL ECOLOGY - animal documentation, birds, behavior, habitat use, Hanford Reach, Yakima River Delta, effect of water-level fluctuations

\section{B-17}

Buck, J. W., and G. L. Andrews. 1987. Hanford Meteorological Station Computer Codes. Vol. 1. The GEN Computer Code. PNL-6279 Vol. 1, Pacific Northwest Laboratory, Richland. Washington. 15 p., App. A and B.

Abstract: General weather forecasts are issued twice a day by the HMS. The GEN computer code archives the 24-hr forecasts, and enables quality assurance checks. The code accesses an input file that contains the date and hour of the previous forecast, and an output file that contains 24-hr forecasts for the current month. The user must fill in a data entry form of 14 fields that describe various weather conditions. This information is appended to the current 24-hr monthly forecast file, which provides an archive for the 24-hr weather forecasts. This report is the first of seven that document computer codes used at the HMS.

Key Words: AIR AND ATMOSPHERE - archives (records), GEN computer code, Hanford Meteorological Station (I-IMS), weather forecasts

\section{B-18}

Buck, J. W., and G. L. Andrews. 1987. Hanford Meteorological Station Computer Codes. Vol. 3. The TANK Computer Code. PNL-6279 Vol. 3, Pacific NorthwestLaboratory, Richland, Washington. 13 p., App. A and B.

Abstract: At the end of each graveyard shift, the HMS issues a forecast of average wind speeds (eight hourly) and wind gusts at the 50-ft level. This "tank farm forecast" is used by the waste management crew at Hanford to schedule daily work loads. The forecast covers $8 \mathrm{hr}$ (0800-1600 during Pacific Standard Time or 0700-1500during Pacific Daylight
Time). The day-shift forecaster may modify the tank farm forecast to reflect changing wind conditions. The TANK computer code archives the forecasts and enables quality assurance checks. The code accesses an input file that contains the previous forecast data, and an output file that contains tank farm forecasts for the current month. The user must complete a data entry form of 12 fields, which is appended to the monthly forecast and records the tank farm forecasts.

Kev Words: AIR AND ATMOSPHERE-archives (records), Hanford Meteorological Station (HMS), TANK computer code, wind forecasts

\section{B-19}

Buck, J. W., and G. L. Andrews. 1987. Hanford Meteorological Station Computer Codes. Vol. 5. The TOWER Comnuter Code. PNL-6279 Vol. 5, Pacific NorthwestLaboratory, Richland, Washington. 15 p., App. A and B.

Abstract: The HMS archives data on wind, dry bulb temperature, and soil temperature gathered each hour from a 410-ft tower. These data include measurements of wind speed and direction at seven heights, eight dry bulb temperatures, and three soil temperatures. The TOWER computer code records these measurements and enables quality assurance checks. The code accesses an input file, which contains the hour and date of the previous archive, and an output file, which contains tower weather observations for the current month. A user must complete a data entry form consisting of 25 fields, which is appended to the monthly file and records the tower data gathered hourly.

Key Words: AIR AND ATMOSPHERE- archives (records), Hanford MeteorologicalStation (HMS), TOWER computer code, weather observations

\section{B-20}

Buelt, J. L., W. Conbere, M. D. Freshly, R. J. Hicks, W. L. Kuhn, D. A. Lamar, R. J. Serne, and J. L. Smoot. 1988. The Predicted Impacts to the Groundwater and Columbia River from Ammoniated Water Discharges to the 216-A-36B Crib. PNL-6463, Pacific NorthwestLaboratory, Richland, Washington. Irregular pages, App. A through C. 
Abstract: Until August 1987, the 316-A-36B crib in the 200-E Area on the Hanford Site accepted ammoniated water discharges. This report addresses known hazardous chemicals associated with the discharges, but is primarily concerned with $\mathrm{NH}_{4} \mathrm{OH}$. While flow to the crib is relatively constant, the estimated discharge of $\mathrm{NH}_{4} \mathrm{OH}$ varies from negligible to a maximum of $10,000 \mathrm{~g}-\mathrm{mol} / \mathrm{hr}$. Discharges are intermittent, and the amount delivered to ground water is a function of soil sorption, microbiological conversion rates of $\mathrm{NH}_{4}$ to $\mathrm{NO}$, and $\mathrm{NO}$, and ground-water dispersion.

Conversion of $\mathrm{NH}_{4}$ to $\mathrm{NO}$, and $\mathrm{NO}$, is rapid and complete, and predicted concentrationsof $\mathrm{NO}$, in ground water are noticeable. The concentration calculated to be in ground water beneath the 316-A$36 \mathrm{~B}$ crib is $430 \mathrm{mg} / \mathrm{L} \mathrm{NO}$, under maximum yearly average operations, and $320 \mathrm{mg} / \mathrm{L}$ under operating conditionsfor FYs 1984 through 1987. (Drinking water standards of $45 \mathrm{mg} / \mathrm{L}$ do not apply because the Hanford Site has no community water systems.) Therefore, ammoniated water applied to the crib has a significant effect on observed NO, concentrations in nearby ground water. However, assuming maximum discharge and complete microbiological conversion, predicted levels of $\mathrm{NO}$, in the river $(3 \mathrm{x}$ $10^{-4} \mathrm{mg} / \mathrm{L}$ ) are more than 5 times less than drinking water standards.

The effect of leaching the soil column with clean water delivered at the same discharge rate to the 316A-36B crib was modeled. NO, in the aquifer at the crib boundary began to drop in about 75 days. Concentrations at a future control-zone boundary started to drop in about 650 days, and neared zero in about 730 days.

Kev Words: EFFLUENTS AND WASTES - ammonium hydroxide, conversion of ammonia, liquid effluents, hazardous materials, nitrate, waste disposal, 100 Areas, 316-A-36B crib

\section{C-1}

Cadwell, L. L., and P. A. Beedlow. 1984. Evaluation of Surface Covers for Decommissioninn the 100 Areas Ground Disposal Sites at Hanford. UNI2945, Prepared by Pacific Northwest Laboratory for UNC Nuclear Industries, Richland, Washington. 11 p., App. A.
Abstract: Treatments were evaluated for stabilizing the surface of ground disposal sites in the 100 Areas at Hanford. Options included continued use of soil sterilants, seeded grass cover, natural vegetation, vegetation combined with rock mulch, and "do nothing." Contaminants were lost at the sites primarily by physical transportby plants and animals, and leaching to ground water. The evaluations assumed the surface covers alone might not be sufficient for complete decommissioning, but that a properly selected surface cover would reduce the risk that contaminants would escape by biotic intrusion and leaching.

The preferred cover was vegetation with a thin $(<6$ in) surface layer of rock mulch. Plants for seeding the cover should be selected from those adapted to the Hanford climate. The plant species should be selected from test plots, because repeated use of soil sterilants and thick rock covers have created unnatural conditions at the 100 Areas burial sites. Although vegetation alone does not ensure complete or longterm isolation of wastes, they offer advantages over the current practice of annual herbicide application. Vegetation intercepts precipitation before it enters the waste and returns much of it to the atmosphere by evapotranspiration. Vegetation provides an aesthetically pleasing appearance while reducing erosion. More extensive site characterization may show that biotic and/or moisture barriers are needed for waste containment. Therefore, vegetation should be considered as a temporary cover until more information on the sites is available.

Kev Words: EFFLUENTS AND WASTES - barrier systems, remedial assessment, shallow land burial, waste disposal/treatment, vegetative cover, 100 Areas

\section{C-2}

Cadwell,L. L., and R. E. Fitzner. 1984. "Nuclear Fuel-Cycle Radionuclidesin Raptor Castings: Implications for Environmental Monitoring." Health Phvs, 47:723-728.

Abstract: Regurgitated material containing the nondigestible remains of prey (raptor castings) may accurately reflect the composition of known environmental y-emitting radionuclides. Raptor castings can be easily obtained and used to monitor the presence 
of biologicallyavailable radionuclides. Castings also provide a useful adjunct to monitoring programs at sites where small mammals may burrow into buried waste.

Kev Words: TERRESTRIALECOLOGY - biomonitoring, methods, radioecology, raptors.

\section{C-3}

Cass, A., G. S. Campbell, and T. L. Jones. 1981. Hvdraulic and Thermal Properties of Soil Samples From the Buried Waste Test Facilitv. PNL-4015, Pacific Northwest Laboratory, Richland, Washington. Irregular pages, App. A.

Abstract: The Buried Waste Test Facility (BWTF) was constructed at Hanford to study contaminant transport in unsaturated soil, as applicable to shallow land burial techniques. Data were collected to help explain water movement at shallow depths and evaporation from bare soil. The theory of heat and water flow is briefly discussed to show the importance of the coefficients and properties measured including soil characteristics, hydraulic conductivity, thermal conductivity, bulk density, and particle size distribution.

The soil characteristicsfunction shows that BWTF soil can be drained to a saturation ratio of 0.4 at a water potential of only $-3.0 \mathrm{~J} / \mathrm{kg}$, which is consistent with particle size distribution. Conductivity data to date were consistent with other data for similar soils on the Hanford Site. Thermal conductivity data were consistent with predicted trends, showing increasing values with increasing data content; the range of values were indicative of sandy soils. An analytic expression pro-vided an empirical but accurate way to describe thermal conductivity and to calculate thermal diffusivity.

Kev Words: GEOLOGY AND HYDROLOGY BWIP site, evaporation, hydraulic conductivity, particle size distribution, soil characteristics, thermal conductivity

\section{C-4}

Catlin, R. J. 1980. Assessment of the Surveillance Program of the High-Level Waste Storage Tanks at
Hanford. Report to U.S. Department of Energy, Assistant Secretary for Environment, Washington, D.C. $231 \mathrm{p}$.

Abstract An independentassessment of radioactive waste storage tanks at Hanford was conducted by the Office of Environmental Complianceand Overview. Early site design philosophy, which relied on the soil and site hydrology for secondary containment, led to the construction of single-shell tanks. Leaks to date from these tanks have caused no significant radiation hazard to public health and safety. Present design philosophy, which considers contact of radioactive waste with the soil as undesirable, has led to construction of double-shell tanks. After the first tank leak in 1958, transfer of the contents of leaking tanks to sound tanks, and concentration of waste in tanks by evaporation, was initiated.

Fourteen major conclusions were reached about the technical adequacy of waste tank surveillance at Hanford, and several recommendations were given. The report agreed with a technical review by the National Academy of Science in 1978 that there has been no significant radiation hazard from wastemanagement operations at Hanford, and that most portions of the surveillance program were adequate. However, an additional 10 to 15 tanks were projected to become unsound in the next several years, and formal criteria to establish tank soundness was recommended. Development of in-tank monitoring for measuring interstitial liquids has not kept up with waste solidification. Frequency of monitoring in dry wells and horizontal lateral wells should be determined on the basis of each tank. Various reports and documents relating to operations and surveillance of the waste tanks lacked consistency and held erroneous information. Future planning must consider the feasibility, relative risks, and benefits of alternative actions.

Kev Words: EFFUENTS AND WASTES - environmental assessment, Hanford Site, high-level wastes, radioactive waste, tanks surveillance, 200 Areas

\section{C-5}

Chapman, D. W., D. E. Weitkamp, T. L. Welsh, and T. H. Schadt. 1983. Effects of Minimum Flow Regimes on Fall Chinook Spawning at Vernita Bar 1978-82. Prepared for Grant County Public Utility 
District,Ephrata, Washington by Don Chapman Consultants, Inc. and Parametrix, Inc. 158 p., App. A and $\mathrm{B}$.

Abstract: The effects of flow fluctuationsfrom power generation at Priest Rapids Dam on the spawning of fall chinook salmon and egg incubation were studied for 5 years at Vernita Bar (above the Hanford Reach). Depth of deposited eggs (7.5 inches average) allowed coverage by intergravel water after flows receded. Redds were dug within $24 \mathrm{hr}$, and spawning female salmon usually returned to their redds after displacement by low flows. Periodic minimum flows for up to $8 \mathrm{hr}$ each day did not influence redd distribution. With high numbers of spawners, redds constructed early (Oct. 25-30) were vulnerable to overlap by mid-November because females spawning first had died and could not defend their redds.

Water velocitiesfaced by spawning chinook salmon at Vemita Bar were 36 to $120 \mathrm{kcfs}$, exceeding known criteria. Water depth apparently had little importance in selection of a redd site or spawning by fish. When flow was reduced to $36 \mathrm{kcfs}$ (minimum regulated flow) or to $50 \mathrm{kcfs}$, the main effect was to lower the surface of intergravel water over several hours to the minimum depth of egg deposition. In general, reduction of daily flows to $36 \mathrm{kcfs}$ below Priest Rapids Dam during spawning and incubation did not reduce survival of intergravel embryos at the $70 \mathrm{kcfs}$ level on Vernita Bar. Laboratory tests showed that 8-hr daily dewatering of eggs, a worsecase situation at Vemita Bar, had no effect on eggs. However, any dewatering beyond 1 or $2 \mathrm{hr}$ significantly reduced survival of alevin phases unless bank-stored water flooded the redds. Hatchery fish (primarily from Priest Rapids releases) made up 33,18 , and $24 \%$ of the carcasses near Vernita Bar in 1980,1981, and 1982.

Key Words: AQUATICECOLOGY - chinook salmon, environmental assessment (general), Hanford Reach, intergravel development, fish spawning, Vernita Bar, effects of water-level fluctuations

\section{C-6}

Chockie, A. D., C. J. Hostick, and C. Winter. 1986. Performance Assessment of the Proposed Monitored Retrievable Storage Facility. PNL-5765, Pacific
Northwest Laboratory, Richland, Washington. Irregular pages, App. A and B.

Abstract: A performance evaluation was conducted by PNL to determine if the conceptual monitored retrievable storage (MRS) facility could process spent reactor fuel at the specified design rate of 3600 metric tons of uranium (MTU) per yea.. Performance was assessed with the computer model COMPACT (Computer Optimization of Processing and Cask Transport) to simulate facility operation. The model addressed three operational aspects - MRS/ waste transportation interface, cask handling capability, and disassembly/consolidation (hot cell) operations. Conclusions were that: 1) The facilities and equipment had a capacity beyond the design rate, which provided a reserve to compensatefor unexpected events. 2) The facility's maximum maintainable capacity for processing was about 4800 MTU per year.

Key Words: EFFLUENTS AND WASTES - radioactive waste management, COMPACT model, monitored and retrievablestorage facility (conceptual), waste disposal

\section{C-7}

Clark, D. C. 1987. Interim Economic and Demographic Profile - Benton and Franklin Counties, Washington. Working Draft, BWIP Repository Project. PNL-6387 (BHARC-800/87/024), Pacific NorthwestLaboratory, Richland, Washington. 48 p.

Contents: This is one of five Socioeconomic Profile Reports produced by BWIP before the effort ended in late 1987. The reports provide community information associated with Hanford, a possible site for the nation's first geologic repository for radioactive wastes. This report gives a general background for economic and demographic conditions in Benton and Franklin Counties. Profile data include information on employment and income; population size, distribution, and composition; and population characteristics. Outstanding technical issues and data requirements are identified, and a working bibliography is provided.

Key Words: SOCIOECONOMICS - Benton/ Franklin counties, effect of BWIP, demography, economy, employment,income, population distribution, information needs 
Cline, J. F., K. A. Gano, and L. E. Rogers. 1980. "Loose Rock as Biobarriers in Shallow Land Burial." Health Phvs. 39:497-504.

Abstract: A layer of loose rock between buried waste and topsoil successfully prevented plant roots, burrowing mammals, and ants from moving wastes to the biosphere on the arid Hanford Site. Air spaces between the rocks had to be maintained with stones measuring between 3.8 and $7.6 \mathrm{~cm}$ in diameter. Small rocks and asphalt emulsion prevented the topsoil from sifting between rocks and making a pathway for plant roots to the waste material.

Kev Words: EFFLUENTS AND WASTES - radioactive waste, remedial studies, rock barriers, waste disposal

C-9

Cline, C. S., J. T. Rieger, and J. R. Raymond. 1985. Ground-Water Monitoring at the Hanford Site, January-December1984. PNL-5408, Pacific Northwest Laboratory, Richland, Washington. 54 p., App. A through D.

Abstract: Samples collected and analyzed by PNL from a network of wells were used to identify radioactive and nonradioactivematerials in ground water beneath Hanford, and to evaluate possible effects on people and the environment. Sampling in 1984 showed that tritium and nitrates continued to move generally eastward toward the Columbia River. The tritium plume was similar in shape to previous years. Startup of the PUREX plant in December 1983 had no effect on ground water. The calculated, annual whole-body dose received from drinking ground water at the Fast Flux Test Facility (FFTF) was $0.46 \mathrm{mrem}$, based on an occupational ingestion rate of $250 \mathrm{~L} / \mathrm{yr}$ and a dose commitment of 50 years. This figure was less than $15 \%$ of the Washington State dose standard of 4 mrem per year. Radioactivity was less at three other locations where ground water was used for drinking.

Some constituents in ground water entered the Columbia River via springs and subsurface flow, primarily in the $100-\mathrm{N}$ and 300 areas and along the shoreline near the Hanford townsite. Dilution reduced this inflow by several orders of magnitude. In 1984, tritium contributed by ground water was 5 $\mathrm{pCi} / \mathrm{L}$ compared to $130+/-15 \mathrm{pCi} / \mathrm{L}$ background in river water. Strontium-90concentration in the Columbia River from springs in the 100-N Area was $0.07 \mathrm{pCi} / \mathrm{L}$, a negligible amount compared to the state and federal standard for drinking water of $8 \mathrm{pCi} /$ L.

Key Words: HANFORD SITE - environmental monitoring, FFTF, ground water, drinking water, monitoring wells, nitrate, radioactivity, river water, shoreline springs, tritium, unconfined aquifer

\section{C-10}

Cluett, C., P. A. Bolton, S. Malhotra, J. R. McStay, and J. A. Slingby. 1984. Nuclear Waste Repository in Basalt: Preliminary Socioeconomic Assessment. RHO-BW-CR-142P/BHARC-400/83/023, Rockwell Hanford Operations, Richland, Washington. Irregular pages.

Contents: This report assesses the social and economic impacts that could be caused by the construction and operation of the proposed BWIP at Hanford. Historical socioeconomic trends and current conditions in the area are described. Future conditions without the BWIP and potential impacts from BWIP under two regional development scenarios are projected and assessed. An overall mitigation management and strategy plan is suggested. The report examinesemployment, labor supply, population change, housing, local transportation, revenues, and expendituresfor public services. It documents the marked demographic and economic decline that occurred since 1981, and concludes that future growth will resume at a slower pace after about 1985 . Recommendations are made for frequent updating of the data base and for improving analyses of socioeconomic impacts.

Kev Words: SOCIOECONOMICS - current conditions, effects of BWIP, employment, expenditures, housing, local transportation, mitigation strategies, potential socioeconomic effects, revenues, trends, work force 
Collins, E., and H. Gaines. 1987. 'The Design of the TransportableGroutEquipment Facility at Hanford." In Waste Management '87. Proceedings of the Symposium on Waste Management. Vol, 3 Low-Level Wastes, ed. R. G. Post, pp. 47-53. University of Arizona Press, Tucson, Arizona.

Abstract: The DOE and Rockwell have developed a grouting process for immobilization of various lowlevel radioactive wastes at the Hanford Site. This process has been demonstrated in a pilot facility, and a production-basisprogram is under way. Associated Technologies, Incorporated, has been selected to design, fabricate, and install part of the facility to standards and performance criteria set by the DOE and Rockwell. SGN of France will provide the benefit of remote maintenance experience. Design of a transportable grout facility is described.

Kev Words: EFFLUENTS AND WASTES - grout technology, grout treatment facility, radioactive waste, waste disposal/treatment

\section{C-12}

Conklin, A. W. 1985. "Waste ManagementPractices to Control Biological Transport of Radioactivity at the Hanford Site." In Waste Management ' 85 , Proceedings of the Svmposium on Waste Management. Vol, 2 Waste Policies and Programs. LowLevel Waste, ed. R. G. Post, pp. 319-323. University of Arizona Press, Tucson, Arizona.

Abstract: One goal of waste management on the Hanford Site is to prevent biological intrusion. Practices to reach this goal include elimination of deeprooted vegetation to prevent root contact with radioactive materials, selective herbicide application to prevent regrowth of these plants, planting of shallowrooted plants to compete with deep-rooted plants for moisture, surface stabilization, and environmental surveillance. Past biological incidents include transport by Russian thistle, access by birds to exposed contamination, and burrowing of animals into waste disposal sites. Rockwell, through mitigative actions and continued surveillance, has eliminated or reduced most source terms, thus preventing or inhibiting biological problems. About $60 \%$ of the source term acreage needing work has been stabilized or decontaminated.
Key Words: EFFLUENTS AND WASTES biological intrusion, biomonitoring, radioactive wastes, remedial action, waste disposal sites

\section{C-13}

Conklin, A. W., R. E. Elder, V. G. Johnson, W. L. Osborne, and A. G. Law. 1984. RockwellHanford Operations Environmental Surveillance Annual Report-Calender Year 1983. RHO-HS-SR-83-13REV 1P, Rockwell Hanford Operations, Richland, Washington. $118 \mathrm{p}$.

Abstract: Environmental sampling and survey results during CY 1983 indicated overall compliance with all applicable DOE guidelines and standards. Specifically: 1) Annual average ambient air concentrations of radionuclides were below concentration guides at all monitoring locations in the 200 Areas. Most concentrations of radionuclidesdid not differ significantly from background levels. 2) Radionuclidesin water, vegetation, and sedimentsamples from open ponds and ditches showed no significant increase from 1982. 3) Ground-water samples from 112 monitoring wells near liquid waste storage and disposal facilities were below concentration guides, except for ${ }^{90} \mathrm{Sr}$ at two inactive sites and tritium in one well near an active PUREX crib. A trend of low but increasing ${ }^{90} \mathrm{Sr}$ was noted in one well near Gable Mt. Pond. As in previous years, nitrate concentrations were elevated near several wells but had not increased. 4) All samples from 200 Area grid sites (soil, vegetation,feces) were below Rockwell surface contamination standards. 5) External radiation levels at grid sites were not significantlyincreased by 200 Area operations. 6) As in previous years, some biological transport of radioactive material was noted. Biological transport by vegetation has decreased through soil stabilization and herbicide application. 7) Several radiologicalstatus changes resulted from these radiation surveys.

Kev Words: EFFLUENTS AND WASTES airborneemissions, environmental monitoring, biotransport,radioactivity, 200 Areas

\section{C-14}

Conklin, A. W., R. E. Elder, and W. L. Osborne. 1982. Rockwell Hanford Operations Environmental 
Surveillance Annual Report - Calender Year 1982. RHO-HS-SR-82-13P, Rockwell Hanford Operations, Richland, Washington. $91 \mathrm{p}$.

Abstract: Environmental monitoring indicated overall compliance with applicable DOE and Rockwell guidelines and standards during CY 1982. There was no indication of any radiological health hazard in the Separations Area. Specifically: 1) Annual average ambient air concentrations were below DOE concentration guides (Table II); also, airborne radionuclides did not differ significantly from background levels. 2) Water and vegetation from open ponds and ditches showed no significant increase in radionuclides from 1982; sediment concentrationsat the same locations were generally lower than in 1981. 3) All samples from 200 Area grid sites (soil, vegetation, and feces) were below surface soil contaminationstandards. 4) External radiation at grid sites indicated no significant contribution to ionizing radiation levels from 200 Area operations. 5) Transport of radioactive material by birds and tumbleweeds contaminated several sites, but these were either decontaminatedor posted as radiologically controlled areas. 6) Surveys resulted in several changes in radiological status within the 200 Areas.

Key Words: EFFLUENTS AND WASTES airborne emissions, environmental monitoring, biotransport,radioactivity, 200 Areas

\section{C-15}

Conklin, A. W., R. E. Elder, W. L. Osborne, and J. M. Pisarcik. 1982. Rockwell Hanford Operations Environmental Surveillance Annual Report - Calender Year 1981. RHO-HS-SR-824 P, Rockwell Hanford Operations, Richland, Washington. 105 p.

Abstract: Environmentalmonitoring indicated overall compliance with applicable DOE and Rockwell guide-linesand standards during CY 1981. Surface contamination levels exceeded radiological control requirements in several areas, and corrective actions were taken. There was no indication of any radiological health hazard in the Separations Area. Specifically: 1) Annual average annual air concentrations of radionuclidesindicate compliance with DOE guidelines (Table II). Airborne radionuclide levels were not significantly greater than background. Concentrations of ${ }^{239} \mathrm{Pu}$ in the air near the 216-2-19 Ditch were about $30 \%$ of guidelines because of plutonium resuspension at the head of the ditch (the site was stabilized in fall 1981). 2) Levels of radionuclides in open ponds and ditches did not increase significantly. Total beta concentrationsin 216-U-14 Ditch and 216N-8 Pond (West Lake) exceeded Table II guidelines. Measurements of radionuclidesin sediments were slightly higher in 1981 due to an improved sampling procedure. 3) All samples from 200 Area grid sites (soil, vegetation, feces) were well below applicable standards. 4) Operations in the 200 Areas did not contribute to external radiation at grid sites. 5) Biological transport of radionuclides by pigeons and wind-blown tumbleweeds, detected in 1981, were controlled. 6) Several radiological status changes resulted from these surveys.

Kev Words: EFFLUENTS AND WASTES airborne emissions, environmental monitoring, biotransport, radioactivity,200 Areas

\section{C-16}

Coony, F. M., D. B. Howe, and L. J. Voigt. 1988. Westinehouse Hanford Company Effluent Releases and Solid Waste Management Report for 1987: 200/ 600/1100 Areas. WHC-EP-0141, Westinghouse Hanford Company, Richland, Washington. Irregular pages, App. A through G.

Abstract: Radioactive airborne releases were below WHC administrative control limits (ACL) in CY 1987; they were lower in 1987 than in 1986, primarily because operating levels were lower at the PUREX Plant. Emissions of nitrogen oxides from PUREX Plant and $\mathrm{UO}_{3}$ Plant complied with the EPA permit. All other nonradioactiveairborne emission complied with local regulations.

Values for annual average concentrations of radionuclides in liquid effluents were below ACLs in 1987, and total releases of specific radionuclides were less than in 1986. Amounts of radioactive, lowlevel solid wastes from Hanford Site generators increased 3,040 $\mathrm{m}^{3}$ between 1986 and 1987, primarily from delivery of contaminated soil from Albany, Oregon. One submarine reactor was received. Offsite shipments of dangerous wastes decreased in 1987, while offsite shipments of extremely hazardous wastes to recycling or an approved disposal facility increased. 
Three airborne hazardous releases and nine liquid hazardous releases were reported in 1987. Corrective action was taken in each case. All airborne releases and three of the liquid releases were related to emission of ammonia and ammonium hydroxide during normal plant operations. All sanitary wastewater was discharged to approved septic tank or sewage treatment facilities.

\section{Key Words: EFFLUENTS AND WASTES -} airborneemissions, environmental monitoring, hazardous materials, liquid effluents, radioactivity, sanitary effluents, waste disposal

\section{C-17}

Corley, J. P., D. H. Denham, R. E. Jaquish, D. E. Michels, A. R. Olsen, and D. A. White. 1981. A Guide for Environmental Radiological Surveiliance at U.S. Department of Energy Installations. DOE/ EP-0023, U.S. Department of Energy, Washington, D.C. 215 p., App. A through D.

Contents: Routine environmental surveillance programs for radioactivity have been conducted at government installations since the early days of the atomic energy program. Goals were to determine if: 1) facility operations, waste treatment, and control systems were functioning as designed to contain radioactivity, and 2) applicable radiation and radioactivity standards and effluent control requirements were being met. Programs were tailored, for each location, to site-specific needs.

This guide was developed for the Energy Research and Development Administration and its successor, the DOE, to aid in planning radiological surveillance programs. It is not a manual of detailed mandatory procedures. After the Introduction, chapters discuss Standards and Criteria, Environmental Surveillance Program Planning, Sampling and Measurement Techniques, Quality Assurance, Data Analysis and Statistical Treatment, Dose Estimation — Individual and Public, and Reporting.

Kev Words: RADIOACTIVITY - assessment, data analysis, radiation dose estimates, environmental monitoring, quality assurance, surveillance program

\section{C-18}

Coutant, C. C. 1982. "Evidence for Upstream Dispersion of Adult Caddis Flies (Trichoptera: Hydropsychidae) in the Columbia River." Aquat. Insects 4:61-66.

Abstract Larval stages of caddis flies in the Hanford Reach below the single-purposeproduction reactors accumulate the radioisotope ${ }^{65} \mathrm{Zn}$. Radiozinc was found in levels above background in swarms of adult caddis flies as far as $16 \mathrm{~km}$ above the uppermost reactor. Whether the insects moved only upstream and the distances they flew remain unclear.

Key Words: AQUATIC ECOLOGY - aquatic insects, biotransfer, caddis fly adults, Hanford Reach, radioecology

\section{C-19}

Crass, D. W., and R. H. Gray. 1982. "Snout Dimorphism in White Sturgeon, Accipenser transmontanus, from the Columbia River at Hanford, Washington." Fish. Bull, 80:159-160.

Abstract: White sturgeon in the Hanford Reach, Columbia River, have both long and short snouts.

Key Words: AQUATIC ECOLOGY - snout dimorphism, white sturgeon, Hanford Reach

\section{C-20}

Cushing, C. E. 1988. "Allochthonous Detritus Input to a Small, Cold Desert Spring-Stream." Verh. Internat. Verein.Limnol, 23:1107-1112.

Abstract: Input of allochthonous detritus as an energy source was measured at Snively Springs, foothills of Rattlesnake Mountain, Hanford Site. Several kinds of seeds, especially those modified for transport by wind, represented the main detritus input to three reaches: the Headwaters, Upper Flats, and Lower Flats. Larger leaf and plant parts from riparian plants were the main input in two reaches, Canyon and Transition. The annual input of the area and the total amount of detrital input to Snively Creek was estimated at $2788 \mathrm{~kg} / \mathrm{yr}$. The Headwaters reach had the second lowest total input on an areal basis, but its 
total contribution was the greatest $(820 \mathrm{~kg} / \mathrm{yr})$

because of its relative length.

Kev Words: AQUATIC ECOLOGY - allochthonous detritus, ecological relations, primary production, Snively Creek (Springs)

\section{C-21}

Cushing, C. E. (ed.). 1988. Hanford Site National Environmental Policv Act (NEPA) Characterization. PNL-6415, Rev. 1. Pacific Northwest Laboratory, Richland, Washington.

Contents: This document is an environmental description of the U.S. Department of Energy's Hanford Site, and was prepared to aid compliance with requirements of the NEPA. The description covers, in subsections: Climate and Meteorology; Geoiogy and Hydrology; Ecology; Historical, Archaeological, and Cultural Resources; Socioeconomics; Noise; Models Used to Estimate Environmental Impacts; and Statutory and Regulatory Requirements. Each subsection is referenced. Distribution of the document is controlled to allow for revision and additions (updating).

Kev Words: HANFORD SITE - data summary, generic information, impact models, NEPA characterization, regulatory requirements, site characterization

\section{C-22}

Cushing, C. E., and R. T. Rader. 1982. "A Note on the Food of Callibaetis (Ephemeroptera: Baetidae)." Great Basin Nat. 41:431-432.

Abstract: Callibaetis nymphs (mayflies) in Rattlesnake Springs, Hanford Site, fed almost exclusively on fine particulate organic matter from the stream bed.

Kev Words: AQUATICECOLOGY - leaf decomposition, mayfly nymphs, RattlesnakeSprings, secondary production
Cushing, C. E., W. H. Rickard, and D. G. Watson. 1988. Radionuclide Accumulation by Aauatic Biota Exposed to Contaminated Water in Artificial Ecosystems Before and After Its Passage Through the Ground. NUREG/GR-5047, U.S. Nuclear Regulatory Commission, Washington, D.C. 19 p.

Abstract: Aquatic biota (fish, clams, algae) and an aquaticemergent plant were experimentally exposed to mixtures of radionuclidesin three artificial streams for periods up to 86 days. The streams consisted of industrial water discharged directly into a leaching trench (at Hanford), the same water after it passed $260 \mathrm{~m}$ through the ground, and untreated water from the Hanford Reach.

After passage through the ground, water from the leaching trench still contained measurableamounts of ${ }^{60} \mathrm{Co}$ and ${ }^{90} \mathrm{Sr}$, which were accumulated by all classes of aquatic biota and by tomatoplants grown in a quasi-hydroponic system. These two radionuclides were transported by ground-water flow and remained availablefor uptake by aquatic biota.

Kev Words: RADIOACTIVITY - aquatic biota, bioaccumulation, cobalt-60, ground-watertransport, strontium-90

\section{C-24}

Cushing, C. E., and J. M. Thomas. 1980. "Cu and Zn Kinetics in Myriophyllumheterophyllum Michx. and Potamogeton richardsonii (ar. Benn.) Rydb." Ecology 61:1321-1326.

Abstract: Two species of aquatic macrophytes were transplanted to different sites to examine uptake and retention of copper and zinc. One site was Gable Mt. Pond (at Hanford), which contained high levels of metals in its sediments, one was an offsite pond (Quarry Pond), and one was artificial ponds containing Quarry Pond sediment and Columbia River water. The trace metals passed from water to sediment slowly over this 100-day study. For the plants, half times averaged 3.7 days for uptake and 6.7 days for retention. There was little difference between plant species or trace metals. The main site of uptake was apparently roots (from sediment) rather than shoots (from water). 
Kev Words: AQUATIC ECOLOGY - aquatic plants, Gable Mt. Pond, trace metals (uptake and retention)

\section{C-25}

Cushing, C. E., D. G. Watson, A. J. Scott, and J. M. Gurtisen. 1981. "Decrease of Radionuclides in Columbia River Biota Following Closure of Hanford Reactors." Health Phvs, 41:59-67.

Abstract In January 1971, the last plutonium production reactor using direct discharge of oncethrough cooling water into the Columbia River was closed. Sampling was conducted at three stations in the Hanford Reach to document the decline of radionuclides in biota. The data showed that, in a riverreservoircomplex, measurable concentrationsof fission-producedradionuclides decreased to extremely low or unmeasurable levels 18 to 24 months after the discharges ceased.

Concentrations of ${ }^{60} \mathrm{Co}$ in seston, periphyton, and invertebrates did not decrease as much as other radionuclides, in part because the isotope still seeped into the Hanford Reach from a disposal trench near the $\mathrm{N}$ Reactor. Levels of ${ }^{60} \mathrm{Co}$ in fish showed some decreases, but there was no obvious trend. Biota contained ${ }^{65} \mathrm{Zn}$ in highest concentrations. Amounts of ${ }^{65} \mathrm{Zn}$ in seston and periphyton decreased rapidly and could be measured only until spring 1973. Zinc-65 in caddis fly larvae was no longer measured by February 1973; however, ${ }^{65} \mathrm{Zn}$ in chironomid larvae from McNary Reservoir fluctuated from unmeasurable to $24 \mathrm{pCi} / \mathrm{gm}$ dry weight (DW) because they still ingested contaminated sediment. Zinc- 65 in suckers and squawfish decreased to fairly low, consistent levels of 1 and $3 \mathrm{pCi} / \mathrm{g} \mathrm{DW}$, respectively.

Kev Words: AQUATICECOLOGY - ecological relations, effect of cooling water discharge, Hanford Reach, radioactivity in biota, effect of reactor shutdown

\section{C-26}

Cushing, C. E., and E. G. Wolf. 1982. "Organic Energy Budget of Rattlesnake Springs, Washington." Am. Midl. Nat. 107:404-407.

Abstract: An annual organic energy budget, measured by a "production to respiration ratio" ( $\mathrm{P} / \mathrm{R}$ ratio) where $P / R=1.20$, showed that RattlesnakeSprings was autotrophic. In terms of detrital processing, however, the system was a net importer on an annual basis despite one major export (remissive) event. Suggestions are made to improve the expression and comparison of annual stream energy budgets.

Kev Words: AQUATIC ECOLOGY - organic energy budget, primary production, Rattlesnake Springs

\section{C-27}

Cushing, C. E., and E. G. Wolf. 1984. "Primary Production in RattlesnakeSprings, a Cold Desert Spring Stream." Hydrobiologia 114:229-236.

Abstract: Primary production and respiration were measured in RattlesnakeSprings on the HanfordSite by means of the upstream-downstream diel $\mathrm{pH}-\mathrm{CO}_{2}$ curve and harvest methods. Daily gross primary production $(\mathrm{Pg})$ and net primary production $(\mathrm{Pn})$ rates averaged 8.7 and $0.9 \mathrm{~g} \mathrm{C} / \mathrm{m}^{2} /$ day for periphyton, 0.6 and $0.3 \mathrm{~g} \mathrm{C} / \mathrm{m}^{2} /$ day for watercress, and 9.3 and $1.2 \mathrm{~g}$ $\mathrm{C} / \mathrm{m}^{2} /$ day for total community. Average photosynthetic efficiencies were about 0.22 for periphyton and 0.07 for watercress. Annual community Pg was $2,700 \mathrm{~g} \mathrm{C} / \mathrm{m}^{2} / \mathrm{year}$, and was highest for periphyton. Periphyton Pn (356 g C/m²/year) exceeded that of watercress $\left(87 \mathrm{~g} \mathrm{C} / \mathrm{m}^{2} /\right.$ year $)$. Community respiration was $2,257 \mathrm{~g} \mathrm{C} / \mathrm{m}^{2} /$ year, and was highest for periphyton $\left(2,170 \mathrm{~g} \mathrm{C}^{2} \mathrm{~m}^{2} /\right.$ year $)$.

Desert streams appear to be enigmas in terms of their relationship between autotrophy and heterotrophy, and their ability to be either net importers or exporters of organic matter. That they can be autotrophic and net importers is probably related to their characteristicflash-flood features.

Kev Words: AQUATIC ECOLOGY - periphyton, primary production,respiration, Rattlesnake Springs, watercress

\section{D-1}

Dahlke, H. J., and C. DeFigh-Price. 1983. Tank Assessment Studies for Continued In-Tank Storage of Hanford Defense Waste. RHO-RE-ST-10P, Rockwell Hanford Operations, Richland, Washington. $18 \mathrm{p}$. 
Abstract: Technical information is given after a 7year study that evaluated the underground, singleshell tanks on the Hanford Site for storage of highlevel waste (HLW). Status reports on waste tank assessment were issued in September 1978, October 1980, and October 1982. This effort determined: 1) the time that salt cake, sludge, and terminal liquor could be safely stored in the tanks, and 2) the engineered changes that might extend the safe storage period.

The single-shell tanks can apparently support all loads specified under presently proposed operating conditions. Further, the proposed conditions provide greater soil and equipment loads, higher specific gravity, and higher temperatures than allowed earlier. The tank structure should remain intact if operating conditions do not change. Under present conditions, dome support methods are not warranted with respect to continued structural integrity.

Key Words: EFFLUENTS AND WASTES - highlevel waste, radioactive waste storage, remedial assessment, single-shell tanks, tank integrity

\section{D-2}

Daniel, J. I., D. C. Clark, and P. H. Kaar. 1982. Lona-Term Effects of Waste Solutions on Concrete and Reinforcing Steel. RHO-RE-CR-8 P, Prepared by Construction Technologies Laboratoriesof the Portland Cement Association for Rockwell Hanford Operations, Richland, Washington. 25 p.

Abstract: A 4-year study on concrete degradation helped determine how well the storage tanks containing high-level, radioactive defense waste at Hanford performed over the long term. This effort was part of the DOE Waste Tank Evaluation Program. Concrete and reinforcing steel were exposed, under load and at $180^{\circ} \mathrm{F}$, to simulated double-shell slurry, simulated salt cake solution, and a control solution. Exposure length varied from 3 to 36 months. In all cases, the concrete and reinforcing steel showed no evidence of rusting, cracking, disruption of mill scale or loss of strength.

Kev Words: EFFLUENTS AND WASTES - highlevel waste, radioactive liquids, radioactive waste storage, storage tank integrity
Dauble, D. D. 1986. "Life History and Ecology of the LargescaleSucker (Castostomus macrocheilus) in the Columbia River." Am. Mid. Nat. 16:356-367.

Abstract: All life stages of the large scale sucker occur in the Hanford Reach. Populations were estimated to fall between 12,000 and 15,000 in June and July 1981. Growth rates, determined from scales, was highest during the first 4 years of life, and ranged from 37 to $73 \mathrm{~mm}$ per year until maturity. Fish lived 15 years or more. Both sexes matured when about $400 \mathrm{~mm}$ long (fork length) at 6 to 9 years of age. Spawning peaked in late May and June when water temperatures were $12^{\prime \prime}$ to $15^{\circ} \mathrm{C}$. Their food consisted largely of periphyton and insect larvae.

Key Words: AQUATIC ECOLOGY - food/feeding, fish growth, Hanford Reach, largescale sucker, life history data, population estimate, fish spawning

\section{D-4}

Dauble, D. D., and R. L. Buschbom. 1981. "Estimates of Hybridization Between Two Species of Catostomids in the Columbia River." Copeia 1981:802-810.

Abstract: The largescale sucker and bridge lip sucker hybridize in the Hanford Reach. Estimated portions of hybrids, based on analysis of intermediate meristic characters, ranged from 12.4 to $14.6 \%$ of the total population. Discriminate function analysis reduced subjective variability and lowered estimates of hybridization to 3.0 to $7.1 \%$. Isolating mechanisms leading to artificial crosses may include overlap in spawning time and incomplete habitat segregation. Morphological and color differences at spawning time may help the species recognize each other, thus providing some degree of ethological isolation.

Kev Words: AQUATICECOLOGY - bridge lip sucker, Hanford Reach, hybrids, largescale sucker, life history data, meristic characters

\section{D-5}

Dauble, D. D., R. M. Ecker, L. W. Vail, and D. A. Neitzel. 1987. Downstream Extent of the N Reactor 
Plume. PNL-6310, Prepared for Westinghouse Hanford Company by Pacific Northwest Laboratory, Richland, Washington. 13 p., App. A.

Abstract: The downstream extent of the thermal plume from $\mathrm{N}$ Reactor was described in response to requests from the Washington State Department of Game and the U.S. EPA, Region X. The thermal plume, as defined by the $0.5^{\circ} \mathrm{F}$ isotherm, will extend less than 10 miles downstream at river flows greater than or equal to annual average flows $(120,000 \mathrm{cfs})$. Incremental temperature increases at the OregonWashington border will be less than $0.5^{\circ} \mathrm{F}$ during all Columbia River flows greater than the regulated minimum flow $(36,000 \mathrm{cfs})$. Solar radiation is the major factor affecting temperatures in the Hanford Reach. Because the estimated temperature increase from $\mathrm{N}$ Reactor operations is less than $0.3^{\circ} \mathrm{F}$ under all flow scenarios, fish in the Columbia River will probably not be impacted.

Key Words: HANFORD SITE - environmental assessment, Hanford Reach, N Reactor operation, thermal plume mixing, thermal plume temperature

\section{D-6}

Dauble, D. D., R. H. Gray, and T. L. Page. 1980. "Importance of Insects and Zooplankton in the Diet of 0-age Chinook Salmon (Oncorhynchus tshawytscha) in the Central Columbia River." Northwest Sci. 54:253-258.

Abstract: Feeding of 0-age chinook salmon was evaluated in the Hanford Reach from March through July 1976, and their stomach contents were compared to available food organisms. Aquatic insects formed the bulk of the diet. Midge fly larvae and pupae (Chironomidae) accounted for $78 \%$ by number and $59 \%$ by volume of total ingested items. Consumption of immature aquatic insects was greatest in MarchJune, whereas caddis fly adults (Trichoptera) were important in June and July. The cladocerian Daphnia schodleri became numerically and volumetrically important late in the study. Midge fly larvae dominated benthic samples in April and June, with caddis fly larvae in lesser abundance. Midstream zooplankton tows captured primarily Copepoda.

Key Words: AQUATICECOLOGY - aquatic insects, benthic organisms, cladoceria, food/feeding, juvenile chinook salmon, zooplankton
Dauble, D. D., and T. L. Page. 1984. Fish Distribution Studies Near NReactor. Summer 1983. WHCEP-0178, Prepared by Pacific Northwest Laboratory for UNC Nuclear Industries, Inc., Richland, Washington. 54 p., App. A.

Abstract: Fish were collected from the Hanford Reach near N Reactor by fyke nets lowered from anchored barges, electroshockinggear, and gill nets. Study objectives were to estimate the vertical and horizontal dismbution of juvenile salmon during their late summer outmigration, and to collect information on relative distribution of juvenile resident fish, in order to assess the effects of the discharge plume at $\mathrm{N}$ Reactor.

Most juvenile chinook salmon passing down river in late summer (late season outmigrants) were near the bottom near the mid-channel. Most movement of both salmon smolts and juvenile resident fish took place during darkness. Total numbers of salmon smolts in 1983 were much lower than historical levels and may have influenced catch totals. Juvenile resident fish occurred only inshore and to depths less than $5 \mathrm{~m}$. Largescale sucker (larvae) was the dominant resident fish in the river drift.

Kev Words: AQUATIC ECOLOGY - abundance, distribution, Hanford Reach, juvenile salmonids, juvenile resident fish, outmigration

\section{D-8}

Dauble, D. D., T. L. Page, and R. W. Hanf, Jr. 1984. Distribution of Juvenile Salmonids in the Columbia River near N Reactor, Soring 1984. WHC-EP-0175, Prepared by Pacific Northwest Laboratory for UNC Nuclear Industries, Inc., Richland, Washington. 81 p., App. A.

Abstract: Studies begun in the summer of 1983 in the Hanford Reach were continued. In the spring of 1984, distribution of juvenile chinook salmon during spring outmigration (earlier in the migration season) and the relative dismbution of juvenile resident fish were examined.

Yearling-sized sockeye salmon, chinook salmon, and steelhead migrated mainly near the mid-channel during spring. Larger salmonids were collected 
mostly near the river bottom. Smaller, 0 -age chinook salmon from upstream spawning areas and releases at Priest Rapids hatchery occurred throughout the river cross-section, but preferred near-shore areas, particularly along the Grant County (north) margin. Most downstream movement of all fish took place at night. Resident fish collected by fyke net were mainly adult sculpin, juvenile yellow perch, and juvenile northern squawfish. Along the shoreline, estimates based on fyke net catches were increased with catches from electroshockersand seines.

Kev Words: AQUATICECOLOGY - abundance, distribution, Hanford Reach, juvenile chinook salmon, outmigration, juvenile resident fish

\section{D-9}

Dauble, D. D., T. M. Poston, and R. L. Newell. 1988. Assessment of Aauatic Organisms as Bioindicators of Historical Radionuclide Release to the Columbia River. PNL-6795, Pacific Northwest Laboratory, Richland, Washington. $30 \mathrm{p}$.

Abstract: The types of samples needed to further understand previous releases of radionuclides to the Hanford Reach was examined. Information was first collected to determine relative abundance and persistence of radionuclides historically released at Hanford (e.g., from single-purposereactors, 1944 to 1971). The potential for long-lived radionuclides to bioaccumulate in aquatic organisms was then assessed, and the life history of several common aquatic species was evaluated for this purpose. On basis of this review, strontium appears the only radionuclide suitable for further study. White sturgeon and the common mussel are suitable candidatesfor developing dose reconstruction scenarios. Considerations for tissue analysis of radionuclides in these species include potential for biological turnover and tissue mass.

Kev Words: RADIOACTIVITY - aquatic biota, biomonitoring, Hanford Reach, historical review, radioecology

\section{D-10}

Dauble, D. D., L. W. Vail, and D. A. Neitzel. 1987. Evaluation of the Potential for Fish Passage Through the N Reactor and the Hanford Generating Project Discharges. PNL-6309, Pacific Northwest Laboratory, Richland, Washington. $11 \mathrm{p}$

Abstract: Existing laboratory and field data were used to evaluate the potential for juvenile salmonids migrating downstream to encounter cooling water discharges at both N Reactor and the HGP. Three scenarios were assessed: 1) passage through the HGP plume centerline followed by passage through the $\mathrm{N}$ Reactor plume centerline, 2) passage through the HGP plume centerline plus intersection with the $\mathrm{N}$ Reactor plume, and 3) passage along the plume edge of first the HGP and then the NReactor. It is highly unlikely that a fish would pass through the centerline of both plumes because the two discharges are at different locations and because mixing is rapid in the river water. For the conditions evaluated, exposure to elevated plume temperatures would be too brief to cause mortalities among fish that might encounter both plumes.

Kev Words: HANFORD SITE - environmentalassessment,fish entrainment (plume), Hanford Reach, HGPoperation, N Reactor operation, thermal plume

\section{D-11}

DeFigh-Price, C. 1982. Status of Tank Assessment Studies for Continued In-Tank Storaee of Hanford Defense Waste. RHO-RE-ST4 P, Rockwell Hanford Operations, Richland, Washington. $63 \mathrm{p}$.

Contents: This status report evaluates the reinforcedconcrete, underground tanks for continued storage of high-level, radioactive waste at Hanford. It provides a summary of work completed the past 2 years. Included are: 1) laboratory tests to determine concrete durability when exposed to various forms of wastes, 2) properties of concrete removed from the haunch and wall of a single-shell tank, 3) computer analyses on tank sensitivities to various loads, and 4) analyses of thermal heat transfer for long-term disposal options.

Elevated temperatures continue as the main factor affecting concrete strength, but initial condition of the concrete appears to be most important to determining its present or future condition. Some tanks were exposed to higher temperatures than specified, and concrete samples from a single-shell tank exposed to average temperatures were in better condition than 
predicted. The new data gave no reason to change the conclusion reached in the initial report (September 1978) of the Waste Tank Evaluation program, that: "the single-shell tanks will be serviceablefor the storage of salt-cake waste for decades under currently establishedoperating temperature and load limits."

Key Words: EFFLUENTS AND WASTES - highlevel waste, radioactive waste storage, remedial assessment, waste storage tanks, storage tank integrity

\section{D-12}

Delegard, C. H., and G. S. Barney. 1983. Effects of Hanford High-Level Waste Components on Sorption of Cobalt. Strontium. Neptunium.Plutonium, and Americium on Hanford Sediments. RHO-RE-ST-1 P, Rockwell Hanford Operations, Richland, Washington. 37 p., App. A through C.

Abstract: To judge the feasibility of continued storage of HLW solutions in existing tanks at Hanford, effects of several waste components on the sorption of hazardous radioelements were determined. Experiments identified the effects of 12 HLW solution componentson the sorption of cobalt, strontium, neptunium, plutonium, and americium on three sediments in the 200 Areas. The degree of sorption of strontium, neptunium, plutonium and americium was then quantified with two sediments in terms of concentrations of waste components. Preliminary information was gathered on how waste components influenced solubility of the radioelements.

Of the 12 components studied, $\mathrm{NaOH}, \mathrm{NaAlO}_{2}$, HEDTA, and EDTA influenced sorption of radioelements the most. The chelating complexants HEDTA and EDTA generally decreased sorption by complexing the radioelement metal ions; $\mathrm{NaOH}$ and $\mathrm{NaAlO}_{2}$ decreased sorption of neptunium and plutonium, and increased sorption of cobalt. Sorption of americium was increased by $\mathrm{NaOH}$. Sorption behaviors of radioelements were similar in the three 200 Areas sediments, implying that that soil sorption reactions were similar. Sorption prediction equationsfor reactions of strontium, neptunium, plutonium and americium in 200 Area sediments yielded values of the distribution coefficient, $\mathrm{Kd}$ ', as quadratic functions of waste component concentrations. The equations showed that postulated radioelement migration rates through Hanford sedimentscould change by factors of 13 to 40 by changes in waste composition.

Key Words: RADIOACTIVITY - adsorption, behavior in soil, complexation, high-level wastes, radionuclides, 200 Areas

\section{D-13}

Delegard, C. H., G. S. Barney, and S. A. Gallagher. 1984. "Effects of Hanford High-Level Waste Components on the Solubility and Sorption of Cobalt, Strontium, Neptunium, Plutonium, and Americium." In Geochemical Behavior of Disposed Radioactive Waste, eds. G. S. Barney, J. D. Navratil, and W. W. Schultz,pp. 95-112. ACS Symposium Series 246, American Chemical Society, Washington,D.C.

Abstract: Solutions of HLW, originating from plutonium recovery and waste processing at the Hanford Site for the nation's defense program, are stored in steel-linedconcrete tanks placed in thick sedimentary beds of sand and gravel. Statistically designed experimentswere used to identify the effects of 12 major chemical components of these wastes on solubility and sorption of radionuclides.

The chemical components with the most effects on solubility and sorption of radioelements were $\mathrm{NaOH}$, $\mathrm{NaAlO}_{2}$, EDTA, and HEDTA. The EDTA and HEDTA increased solubility of cobalt, strontium, and americium, and decreased sorption for almost all radioelements studied. Sodium hydroxide and $\mathrm{NaAlO}_{2}$ increased plutonium solubility and decreased neptunium and plutonium sorption. Sodium nitrate decreased neptunium solubility, while $\mathrm{Na}_{2} \mathrm{CO}_{3}$ and HEDTA increased it. These observations support the formation of radioelementcomplexes that are soluble and not strongly sorbed by the sediments near the storage tanks.

Key Words: RADIOACTIVITY - adsorption, behavior in soil, complexation, effects of complexants, high-level wastes, radionuclides, solubility, 200 Areas 
Delegard,C. H., and S. A. Gallagher. 1983. Effects gf Hanford High-Level Waste Components on the Solubilitv of Cobalt. Strontium. Neptunium. Plutonium. and Americium. RHO-RE-ST-3 P, Rockwell Hanford Operations, Richland, Washington. 28 p., App. A and B.

Abstract: Experiments were performed to identify components in HLW at Hanford that significantly affected the solubility of cobalt, strontium, neptunium, plutonium, and americium. Further tests quantified the effects of the significant components on solubility of strontium, plutonium, and americium. The compounds controlling solubility of the radioelements were not identified.

Twelve components of Hanford's HLW were studied. The components HEDTA and EDTA (complexing agents) increased solubility of cobalt, strontium, and americium by complexing the metal ions. Solubility of americium also increased, apparently from complexation by hydroxyacetate and citrate. Sodium nitrate decreased solubility of neptunium by reducing it from (VI) to the less soluble (V) oxidation state. Sodium carbonate and HEDTA increased solubility of neptunium through complexation but, unexpectedly,EDTA decreased its solubility. The components $\mathrm{NaNO}_{3}, \mathrm{NaOH}$, and $\mathrm{NaAlO}_{2}$ increased solubility of plutonium by forming solublecomplexes.

Key Words: RADIOACTIVITY - behavior in soil, high-level wastes, soil sorption, solubility, radionuclides, 200 Areas

\section{D-15}

Delegard, C. H., S. A. Gallagher, and R. B. Kasper. 1981. "Saturated Column Leach Studies: Hanford 216-Z-IA Sediment." RHO-SA-210,Rockwell Hanford Operations, Richland, Washington. 6 p.

Abstract: The leachability of plutonium and americium in sediment obtained from a retired underground liquid waste disposal facility in the 200 Areas was studied under saturated column and batch leaching conditions in the laboratory. Batch leaching studies confirmed that americium concentrations were a function of the dissolution of an americium compound having $\mathrm{pH}$-dependentsolubility. Batch studies also showed that plutonium was not present as $\mathrm{PuO}_{2}$. The concentration of americium and plutonium in the leachate can be enhanced when conditionsfavor increased concentrations of complexing agents at the wetting front. Waste-sediment interactionsat Hanford apparently have altered the high-level waste, so that almost all of the plutonium and most of the americium was retained on the sediment tested. Plutonium was retained because of ion exchange desorption. Plausible environmental leaching conditions might mobilize less than $1 \%$ of the plutonium in the sediment and about $30 \%$ of the americium.

Key Words: RADIOACTIVITY - americium, behavior in soil, high-level wastes, leachability, plutonium, physicochemical properties, 200 Areas

\section{D-16}

Delegard, C. H., R. L. Weiss, R. T. Kimura, A. G. Law, and R. C. Routson. 1986. "Characterization and Anion Exchange Removal of Uranium from Hanford Ground Water." In Waste Management '86. Proceedings of the Symposium on Waste Management. Vol. 1 General Interest, ed. R. G. Post, pp. 545550. University of Arizona Press, Tucson, Arizona. (RHO-RE-SA-116P)

Abstract: In February 1985, uranium concentrations increased abruptly to $0.1 \mathrm{~kg} / \mathrm{m}^{3}$ in ground water beneath a retired liquid waste disposal facility at Hanford. Uranium was present as an anionic carbonate complex that was not sorbable by sediments. The uranium was mobilized by flow from a perched zone of water, caused by recent discharge of cooling water above an impermeable sediment layer nearby. In a unique application of the ALARA concept, an anion exchange-based uranium removal process was developed to minimize spread of the contaminated water and reduce the amounts of uranium present. The process has operated 6 months and treated over $30,000 \mathrm{~m}^{3}$ of ground water, removing about $94 \%$ of the uranium. The treated effluent meets criteria for discharge to the soil.

Kev Words: EFFLUENTS AND WASTES - ground water, Hanford Site, radioactiveliquids, remedial actions, uranium, waste treatment 
Diediker, L. D., and R. K. Ledgerwood. 1980. Drilling:Historv of Core Hole DB-15. RHO-BWILD-29, Rockwell Hanford Operations, Richland, Washington. $42 \mathrm{p}$.

Abstract: Drilling of core hole DB-15, located about 1 mile east of the NW comer of the 200 East Area, was complete in November 1979. The hole was drilled to obtain hydrologic and chemical data on the permeable zones of the Saddle Mountains and Wanapum formations. Zones penetrated during drilling were tested. The testing-as-drilledtechnique, although taking longer and costing more, is recommended when future core holes are drilled.

Kev Words: GEOLOGY AND HYDROLOGY Saddle Mountains basalt, drilling technique, Wanapum basalt, 200 Areas

\section{D-18}

Dong, F. B., M. K. Dugan, and D. C. Clark. 1988. Interim Fiscal Profile Benton and Franklin Counties, Washington. BWIP, Working Draft. PNL-6499 (BHARC-800/87/028), Pacific NorthwestLaboratory, Richland, Washington. $65 \mathrm{p}$.

Abstract: This is a fiscal profile of Benton and Franklin counties, and of the cities of Richland, Kennewick, and Pasco, prepared to support the BWIP before program closure in late 1987. Overall, changes in operating revenues and expenditures corresponded with changes in the local economy. Combinedoperating expenditures of the two counties and the three cities, expressed in current dollars, tripled between 1975 and 1985 from $\$ 18.1$ to $\$ 55.0$ million, an annual average increase of $11.8 \%$. During this time, the population of the Benton-Franklin MSA increased from 100,000 to 140,900 , and the national all-items price index for urban consumers doubled. Adjusted for inflation, per capita expendituresby local governments increased only slightly from \$361.8 in 1975 to \$390.3 in 1985 .

Employment in the Benton-Franklin MSA rose from 40,080 workers in 1970 to a peak of 75,900 in 1981 before declining to 61,100 in 1985 . The decline was largely due to loss of 9,928 jobs at the Washington Public Power Supply System. The population in the
MSA had a similar trend, with a slight lag. Total population was 93,356 in 1970 , growing to 147,900 in 1982, then falling to 139,300 in 1986 . As a result, governmental jurisdictions were faced with rapidly changing demand for services, which affected their responsibilitiesand finances. Adjustments are ongoing, and have affected current fiscal conditions.

Kev Words: SOCIOECONOMICS - effect of BWIP, Benton-Franklin MSA, demography, economy, employment, population

\section{D-19}

Dunigan, P. F. X., Jr., W. Lei, and W. F. Rickard. 1980. "Pocket Mouse Population Response to Winter Precipitation and Drought." Northwest Sci. 54:289-295.

Abstract: Pocket mice were live-trapped on parts of the Arid Land Ecology (ALE) Reserve, Hanford Site, to examine relationships between precipitation in fall and winter and mouse abundance in the spring. The study begin in April 1977, after one of the driest winters on record in eastern Washington, and concluded in June 1978, after a winter of average precipitation. Production of plants (phytomass) was greatest in spring 1978, and was accompanied by higher numbers of pocket mice. The strong correlation was probably mediated by availability of quality food items such as fresh seeds.

Key Words: TERRESTRIALECOLOGY - ALE, behavior, effect of precipitation, Great Basin pocket mouse, reproduction

\section{E-1}

Early, T. O., G. K. Jacobs, and D. R. Drewes. 1984. "GeochemicalControls on RadionuclideReleases from a Nuclear Waste Repository in Basalt. Estimated Solubilities for Selected Elements." In Geochemical Behavior of Disposed Radioactive Waste, eds. G. S. Barney, J. D. Navratil, and W. W. Schulz, pp. 147-166. ACS Symposium Series 246, American Chemical Society, Washington,D.C.

Abstract: Two basalt flows in the Grande Ronde Formation beneath the Hanford Site are candidates for BWIP, a repository for high level wastes containing radioactivity. Solubility controls are needed to 
predict the rate of release and migration of key radionuclidesfrom the repository. Thermodynamic data for a variety of actinides and fission products were determined, and ground water from the Grande Ronde Formation was analyzed.

Solids predicted to control solubility for selected radionuclidesinclude hydroxides and hydrous oxides (palladium, antimony, samarium, europium, lead, and americium); oxides (nickel, tin, thorium, neptunium, and plutonium); elements (selenium and palladium); and silicates (zirconium and uranium). Dominant soluble species include hydroxy complexes (zirconium, palladium, tin, antimony, samarium, europium, thorium, uranium, neptunium, and plutonium) and carbonatespecies (nickel, samarium, europium, lead, uranium, neptunium, plutonium, and americium). In addition to limitations in thermodynamic data, solubility estimates of radionuclides are sensitive to 1) Eh and the degree of redox equilibrium, 2) temperature,3) formation of metastable solid phases, and 4) coprecipitation. The effects of Eh are significant for selenium, palladium, and tin, and possibly uranium and neptunium. Solubility estimates were made for ambient temperatures (about $55^{\circ}+/-5^{\circ} \mathrm{C}$ ) for Grande Ronde basalts. The effects of metastability and coprecipitationcannot be stated quantitatively.

Kev Words: RADIOACTIVITY - high-level wastes, physicochemicalproperties, radionuclides, redox potential (Eh), solubility, soil sorption

\section{E-2}

Eberhardt,L. E. 1987. Ecology of Great Basin Canada Goose Broods in Southcentral Washington. Ph.D. Thesis, Oregon State University, Corvallis, Oregon.

$93 \mathrm{p}$.

Abstract: Adult female Canada geese used an average of $8.8 \mathrm{~km}$ of the Columbia River when raising broods to fledging. Movement of broods was not significantly influenced by age of goslings or weather. Broods were most active during late morning and relatively inactive at night. During the prefledging period, feeding was the main activity of broods and adult females, involving about 54\% and $45 \%$ of daylight hours, respectively. At fledging, time spent inactive and preening increased while time spent active and feeding decreased.
Broods preferred land within $5 \mathrm{~m}$ of the Columbia River shoreline. Shoreline pastures fertilized and grazed by cattle were used for foraging by local broods of geese, but did not attract broods from surrounding areas. Broods appeared most susceptible to human disturbanceduring the first few weeks after hatching, but older broods were relatively tolerant. Fifteen (55.6\%) of 27 adult females fledged at least one gosling. Daily survival rates of goslings were significantly lower during the first 14 days (0.971) compared to the rest of the 70-day rearing season (0.995). The overall estimated survival rate for goslingsduring rearing was 0.491 , considerably lower than previously recorded for this species.

Kev Words: TERRESTRIALECOLOGY - behavior, Canada goose, habitat use, hatching success, nesting, survival

\section{E-3}

Eberhardt,L. E., I. E. Ball, Jr., and R. G. Anthony. 1986. Method for Live-Capturing Adult Canada Geese on Their Nests. Information Bulletin No. 8633, U.S. Fish and Wildlife Service, Washington, D.C. $2 \mathrm{p}$.

Abstract: Adrop-net was developed and tested at Hanford to capture adult female geese on their nests. The capture unit was a weighted monofilament gill net suspended about $1.5 \mathrm{~m}$ above the nest and dropped by remote release of a trigger mechanism. Comer posts supported the net.

Key Words: TERRESTRIAL ECOLOGY - capture technique, Canada goose,

\section{E-4}

Eberhardt,L. E., and L. L. Cadwell. 1985. "RadioTelemetry as an Aid to Environmental Contaminant Evaluation of Mobile Wildlife Species." Environ. Monit. Assess. 5:283-289.

Abstract: Radio transmittersare useful in determining the use and movement from contaminated sites by highly mobile wildlife. Programs that monitor wildlife for environmental contaminants from local sourcescan maximize the amount of information obtained from an animal by using radiotelemetry 
data. The method is applied to two mobile species, mule deer and mallard ducks, to document their use of waste ponds contaminated with low-level radioactive wastes on the Hanford Site and their subsequent movement.

Key Words: TERRESTRIAL ECOLOGY - biomonitoring, mallard duck, mule deer, radiotelemetry

\section{E-5}

Eberhardt,L. E., L. L. Cadwell, and E. E. Hanson. 1984. "Radionuclide Concentrations in Mule Deer with Reference to Waste-ManagementPonds on the Hanford Site." Health Phvs, 47:753-759.

Abstract: The amount of time mule deer spent near ponds receiving low-level radioactive wastes on the Hanford Site and the levels of radionuclides they contained was compared. All deer contained low, but detectable, amounts of ${ }^{137} \mathrm{Cs}$ in their muscle, liver, and rumen contents and ${ }^{90} \mathrm{Sr}$ in their bone. Several other radionuclides were detected in rumen samples, but were not incorporatedintomuscle and liver tissue. The amount of ${ }^{137} \mathrm{Cs}$ and ${ }^{90} \mathrm{Sr}$ and the amount of time that deer spent near the ponds showed a positive, significantcorrelation. The variability of ${ }^{137} \mathrm{Cs}$ in muscle was higher in deer living near the ponds than in deer residing at a distance. Levels of radionuclides in deer at Hanford appear to be reduced from levels observed in the 1960's.

Kev Words: RADIOACTIVITY - terrestrial animals, biomonitoring, cesium-137, strontium-90, waste disposal ponds, 200 Areas

\section{E-6}

Eberhardt,L. E., E. E. Hanson, and L. L. Cadwell. 1982. Analvsis of Radionuclide Concentrations and Movement Patterns of Hanford Site Mule Deer. PNL4420, Pacific Northwest Laboratory, Richland, Washington. 30 p., App. A and B.

Abstract: Mule deer with radio collars were monitored at Hanford from 1980 through 1982 to: a) compare radionuclide concentrations near the 200Areas waste sites with those at other locations, and b) document movement patterns, particularly offsite. Cesium-137 in muscle and liver tissues, and ${ }^{90} \mathrm{Sr}$ in bone were statistically higher in deer near the 200
Areas than in control animals. However, radionuclide levels were lower in deer at both locations than levels observed before in deer on the Hanford Site. Cesium-137 and ${ }^{90} \mathrm{Sr}$ levels were more variable in deer near the 200 Areas waste sites than in control animals exposed only to background levels (fallout). Home ranges of deer averaged $39 \mathbf{k m}^{2}$, and 10 deer made offsite movements. Radiotelemetry indicated that only about $8 \%$ of the Hanford deer herd was harvested each year. As a result, the herd appeared to have a disproportionate number of older animals.

Kev Words: TERRESTRIALECOLOGY - behavior, biomonitoring, habitat use, mule deer, offsite movement, onsite ponds (200 Areas), radioecology, 200 Areas

\section{E-7}

Eberhardt,L. E., E. E. Hanson, and L. L. Cadwell. 1984. "Movement and Activity Patterns of Mule Deer in the Sagebrush-SteppeRegions." J. Mammal. 65:404-409.

Abstract: The movement and activity patterns of radio-collared mule deer were studied on the Hanford Site from 1980 to 1982. The home range for adult deer averaged $39.3 \mathbf{~ k m}^{2}$, and home range size did not differ significantly between male and female deer. Intensity of use was not uniform and physical features within the home range, such as trees and large water bodies, influenced deer movement. The Columbia River was not a barrier to movement. During almost 25 deer-years of monitoring, 3 of 37 monitored deer left their original home ranges. Seven deer made sporadic, temporary wandering movements up to $15 \mathrm{~km}$ beyond their normal home range boundaries.

Kev Words: TERRESTRIALECOLOGY - behavior, biomonitoring, home range, mule deer, habitat use

\section{E-8}

Eddy, P. A., C. S. Cline, and L. S. Prater. 1982. Radioloeical Status of the Ground Water Beneath the Hanford Site. January-December 1981. PNL-4237, Pacific Northwest Laboratory, Richland, Washington. 48 p., App. A through C. 
Abstract: Monitoring wells (299) were sampled at various times during CY 1981 for radioactiveand chemical constituents. Tritium and nonradioactive nitrate, easily transportedin ground water, were used to trace movement of contamination. Gross beta activity $\left({ }^{106} \mathrm{Ru}\right)$ had become so low it was no longer a major radionuclidecontaminant.

The tritium plume showed much the same shape in 1981 as in the last four years, but concentrations were increasing near the Columbia River. The size of the nitrate plume appeared stable, and concentrations remained high near the $100 \mathrm{H}$ Area because of previous leaks from an evaporation facility. The overall quality of ground water under the Hanford Site was generally comparable to that of other ground waters in eastern Washington. Two studies were started to determine the contribution of ground-water contaminants to the Columbia River. Data were presented from all surveillance efforts during CY 1981.

Kev Words: HANFORD SITE - environmental monitoring, ground water, nitrate, contaminated plume, radioactivity, tritium, unconfined aquifer, 100 Areas, 200 Areas

\section{E-9}

Eddy, P. A., L. S. Prater, and J. T. Rieger. 1983. Ground-WaterSurveillance at the Hanford Site for CY-1982. PNL-4659, Pacific Northwest Laboratory, Richland, Washington. 39 p., App. A through C.

Abstract: Monitoring wells (324) were sampled at various times during CY 1982 for radioactiveand chemical constituents. Tritium and nitrate, readily transported in ground water, were extensively monitored. Differentamounts of waste water have been discharged to the ground at Hanford Site since 1944. The underground plumes change in response to ground-water flow, ionic dispersion, and radioactive decay.

The tritium plume is shaped much the same in 1982 as in the past four years, but concentrations continued to increase near the Columbia River. The contribution of tritium from ground water at Hanford to the river cannot be separated from additions by other sources. The size of the nitrate plume appeared to be stable. Nitrate concentrationsremained high near the $100 \mathrm{H}$ Area. Concentrations and distribution of gross beta radioactivity in ground water have decreased for several years, and were now at insignificant levels over most of the aquifer. Data were presented from all surveillance efforts during CY 1982.

Key Words: HANFORD SITE - environmental monitoring, ground water, nitrate, contaminated plume, radioactivity, tritium, unconfined aquifer, 100 Areas, 200 Areas

\section{E-10}

Eddy, P. A., S. S. Teel, J. R. Raymond, and W. H. Bierschenk. 1988. Water Quality: Historic Values and Impact of Drilling Activities During FY 1988 at th $\mathrm{R}$ Washington. PNL-6497, Pacific NorthwestLaboratory, Richland, Washington. 38 p., App. A and B.

Abstract: This is one of seven environmental topical reports produced by BWIP before project termination in late 1987. The reports provide environmental information on the Hanford Site, a possible location for the nation's first geologic repository to hold radioactive wastes. This report provides chemical and radiological data from springs (generally on ridges and mountains) and wells (generally on low-lying areas) throughout the Hanford Site. Water from springs is calcium-sodium-bicarbonatein nature and low in total dissolved solids. Spring water is similar to unconfined aquifer water, and probably results from recharge by precipitation at higher elevations. Water in some wells is contaminated from past and present operations at Hanford, primarily from nitrate (chemical) and tritium (radioactive). Water from wells into basalt indicate that chemical features in confined aquifers beneath the RRL and beneath surrounding areas is similar, except for chlorine and fluorine.

The water table near the Reference Repository Location (RRL) has risen under past discharges of liquid effluent, and natural hydraulic gradients have been distorted. Heads in wells that tap the basalt aquifer (confined) vary because of irrigation west of the RRL, but there has been little change in head beneath the RRL. Ground water in the confined and unconfined aquifers can be contaminated by drilling fluids and by interaquiferexchanges caused by drilling. Drilling requires extreme care to prevent ground-water contamination. In addition, disposal of 
some ground water that contains chemicals exceeding drinking water standards must be controlled.

Kev Words: HANFORD SITE - BWIP site, confined aquifer, environmental assessment,fluoride, ground water, nitrate, radioactivity, RRL, shoreline springs, tritium, unconfined aquifer

\section{E-11}

Eddy, P. A., and J. S. Wilbur. 1981. Radiological Status of the Ground Water Beneath the Hanford Site. Januarv-December. 1980. PNL-3768, Pacific Northwest Laboratory, Richland, Washington. 49 p., App. A through C.

Abstract: Monitoring wells (317) were sampled at various times during CY 1980 for radiologicaland chemical constituents. Data describe the movenent of tritium, ${ }^{106} \mathrm{Ru}$, and nonradioactive nitrate as well as their response to ground-water flow, ionic dispersion, and radioactive decay.

The shape of the tritium plume was similar in 1980 to the previous three years, and was mapped as having reached the Columbia River. The size of the nitrate plume appeared to be stable, but concentrations remained high in the $100 \mathrm{H}$ Area as a result of past leaks from an evaporation facility. Gross beta activity (as ${ }^{106} \mathrm{Ru}$ ) continued to recede except for a beta source in the 300 Area. Iodine-129 occurred largely in the upper part of the unconfined aquifer and some was approaching the Columbia River. The impact to the public of ground-water discharges has been evaluated and reported annually in "Environmental Surveillance" reports. The maximum dose, from drinking water at the FFTF, was 0.5 mrem annually.

Kev Words: HANFORD SITE - environmental monitoring, FFTF, ground water, nitrate, contaminated plume, radioactivity, tritium, unconfined aquifer, 100 Areas, 200 Areas, 300 Area

\section{E-12}

Elder, R. E. 1985. "Remedial Waste Management Practices Resulting in the Decline of Airborne Plutonium Adjacent to a Liquid Waste Disposal Ditch at the Hanford Site." In Waste Management '85,
Proceedings of the Symposium on Waste Management, Vol. 2 Waste Policies and Programs,LowLevel Wastes, ed. R. G. Post, pp. 325-328. University of Arizona Press, Tucson, Arizona.

Abstract: Sampling of air at the 216-2-19ditch at Hanford identified the need for interim stabilization, which required covering with soil and planting of vegetation. This ditch, in the 200 West Area, received multigram quantities of ${ }^{239} 240 \mathrm{Pu}$ for 10 years (1971 to 1981). Since 1977, an air sampler at the head of the ditch consistently measured elevated levels of plutonium $\left(0.003\right.$ to $\left.0.044 \mathrm{pCi} / \mathrm{m}^{3}\right)$, apparently from resuspension of the radionuclide in ditch soil. After interim stabilization, levels of ${ }^{239240} \mathrm{Pu}$ in air declined to less than $1 \%$ of their former levels, and are now at Hanford background levels $(0.00008$ $\left.\mathrm{pCi} / \mathrm{m}^{3}\right)$.

Key Words: RADIOACTIVITY - airborne radioactivity, plutonium, remedial action, waste stabilization, 216-2-19 ditch, 200 Areas

\section{E-13}

Elder, R. E., A. W. Conklin, G. W. Egert, D. D. Brekke, and W. L. Osborne. 1986. Rockwell Hanford Operations Environmental Surveillance Annual Report - Calender Year 1985. RHO-HS-SR85-13 P, Rockwell Hanford Operations, Richland, Washington. Irregularpages, App. A through I.

Abstract: Concentrations of airborne radionuclides in the Separations Area were many times less than Rockwell's administrativecontrols (based on ALARA concepts). Concentrationsof airborne ${ }^{137} \mathrm{Cs}$ and ${ }^{239} \mathrm{Pu}$ continued to decline. Levels of ${ }^{90} \mathrm{Sr}$ were slightly elevated, apparently from an inadvertent release in January from a diversion box. On an annual average basis, radioactivityat six of 106 currently active and inactive waste disposal sites monitored in 1986 exceed control values, but no projected offsite dose exceeded DOE limits.

Average concentrationsof radionuclidesin surface soils were only: 1) $\mathbf{0 . 2 5}, 1.4$, and $0.07 \%$ of Rockwell's soil standards for ${ }^{90} \mathrm{Sr},{ }^{137} \mathrm{Cs}$, and ${ }^{239} \mathrm{Pu}$, respectively, in the 200East Area; and 0.28, 2.21, and $0.41 \%$ of the standards for ${ }^{90} \mathrm{Sr},{ }^{137} \mathrm{Cs}$, and ${ }^{239} \mathrm{Pu}$, respectively, in the $200 \mathrm{West}$ Area. The only gamma-emitting radionuclide in vegetation from grid sites to slightly exceed background levels was ${ }^{137} \mathrm{Cs}$. 
Exposure rates from penetrating radiations (primarily gamma rays) in the 200 Areas were consistent with levels of background radiation. As expected, some levels were slightly elevated in radiological control areas and waste management areas. Specific radionuclides in all ponds and ditches associated with the Separations Area were bclow Rockwell control values, remaining similar to 1984 levels.

Kev Words: HANFORD SITE - effluents and emissions, environmental monitoring, radioactivity,radionuclides, radiation dose assessment, regulatory compliance, 200 Areas

\section{E-14}

Elder, R. E., G. W. Egert, A. R. Johnson, and W. L. Osborne. 1986. Rockwell Hanford Operations Environmental Surveillance Annual Revort - Calendcr Year 1986. RHO-HS-SR-86-13P, Rockwell Hanford Operations, Richland, Washington. Irregular pages, App. A through J.

Abstract: Concentrations of airborne radionuclides in the Separations Area at Hanford were many times less than Rockwell's Derived Concentration Guides (DCGs). Data since 1979 showed a continued decline in airborne ${ }^{137} \mathrm{Cs},{ }^{90} \mathrm{Sr}$, and ${ }^{239} \mathrm{Pu}$. The major event to affect ambient air concentrations was the partial meltdown of the Chernobyl NuclearStation on April 26,1986, which was first detected on May 13 and lasted 4 weeks. Ground water beneath four waste sites in the 200 Areas, two in use and two inactive, exceeded DCGs on an annual average basis for 1986. Projected offsite doses for none of the four sites exceeded DOE limits. However, Administrative Controls established by Rockwell (based on ALARA concepts) were exceeded at 11 sites on an annual average.

Radionuclidelevels in surface soils throughout the Separations Area were well below all Rockwell soil standards (set to ensure compliance with DOE standards) in 1986. No increase in soil concentrations since 1978 was evident. The only gamma-emitter in vegetation samples to exceed background levels was ${ }^{137} \mathrm{Cs}$, detected at slightly higher levels at 18 of 53 sites.

Exposure rates from penetrating radiation (primarily gamma rays) in the 200 Areas were consistent with background levels. As expected, external radiation levels were elevated in some controlled areas and near certain facilities, reflecting waste management and chemical processing activities. No significantchange in exposure rates was indicated by trend analysis since monitoring began in 1978 . Radionuclides in all surface waters associated with operations in the 200 Areas were below DCGs. Trends from special sampling for radionuclides indicated that operational control over much of the area has improved, particularly for vegetation.

Kev Words: HANFORD SITE - effluents and emissions, environmental monitoring, radioactivity, radionuclides, radiation dose assessment, regulatory compliance, 200 Areas

\section{E-15}

Emery, R. M., and M. C. McShane. 1980. "Nuclear Waste Ponds and Streams on the Hanford Site: An EcologicalSearch for Radiation Effects." Health Phys, 38:787-809.

Abstract: Ponds and streams at Hanford were examined to detect limnologicaland radiological relationships. Maximum dose from sediments and nuclide concentrationsin water provided radiological differentiation of systems. While onsite ponds and streams could be grouped into three categories based on radionuclides, only one system (100 N trench) had dose rates exceeding $1 \mathrm{R} / \mathrm{wk}$. However, maximum alpha concentrationsin Z-19 ditch water and maximum beta-gamma concentrations in $100 \mathrm{~N}$ trench water exceeded $10^{-4} \mathrm{pCi} / \mathrm{L}$.

The aquatic systems supported algae, macrophytes, invertebrates, and somelimes fish. Algae in the 100 $\mathrm{N}$ trench and Z-19 ditch contained less variety in species, but variety among other biota was apparently not associated with the amount of radioactivity. Community structure was as diverse as in Columbia River communities, but less diverse than in some offsite streams. Production of plant life, invertebrates, and fish in Hanford's pond and streams did not appear to vary with nuclear waste contamination, but resembled production in systems uncontaminated with radioactivity. This survey provided no evidence that nuclear wastes at Hanford affected colonization, diversity, or activity of aquatic biota. 
Kev Words: AQUATIC ECOLOGY - community structure, community production, effect of radioactivity, radioactive ponds/streams

\section{E-16}

Evans, J. C., P. J. Mitchell, and D. I. Dennison. 1988. Hanford Site Ground-Water Monitoring for April through June 1987. PNL-6315-1, Pacific NorthwestLaboratory, Richland, Washington. 83 p., App. A and B.

Abstract: Results of ground-water monitoring conducted by PNL and WHC at Hanford from April through June 1987 revealed the presence of certain regulated hazardous materials and radionuclides. Sources included onsite operations and, for some constituents, natural origin. The major contamination problems were: 1) carbon tetrachloride in the 200 West Area; 2) cyanide in and north of the 200 East Area; 3) hexavalent chromium in the $100 \mathrm{~B}, 100 \mathrm{D}$, $100 \mathrm{~K}$, and $100 \mathrm{H}$ areas; 4) chlorinated hydrocarbons near the Central Landfill; 5) uranium at the 216-U-1 and 216-U-2 cribs in the 200 West Area; and 6) tritium and nitrate across the Hanford Site.

Kev Words: HANFORD SITE - environmental monitoring, ground water, hazardous materials (carbon tetrachloride, chlorinated hydrocarbons, cyanide, hexavalent chromium, nitrate), radioactivity, radioactive materials (tritium, uranium)

\section{F-1}

Farnsworth, R. K., M. E. Peterson, and R. N. Wagner. 1987. "Effects of Feed Process Variables on Hanford Vitrification Plant Performance." Trans, Am. Nucl. Soc. 54:94-95.

Abstract: A Hanford waste vimfication plant (HWVP) has been proposed to immobilize highlevel, radioactive liquid wastes on the Hanford Site. Rockwell is responsible for overall design, engineering, and construction. PNL is responsiblefor development of the waste form and the vitrification technology. A multivariate study was conducted to identify feed process variables that significantly affect rheology during waste processing. Addition of sufficient formic acid to reduce the $\mathrm{pH}$ of the slurry below 8 significantly decreased yield stress and apparent viscosities of simulated feed for the vi cation plant. The degree of shear significantly affected melter feed rheology only after the glassforming frit had been blended with waste slurry. Increased shearing of the feed increased yield strength $>100 \%$. Increased yield stress was possibly caused by a reduction of the frit particle size. With a decrease in particle size, the attractive forces bethifeen particle increases, causing yield stress to increase.

Kev Words: EFFLUENTS AND WASTES - highlevel wastes, HWVP, radioactive waste management, remedial plans, vitrification technology

\section{F-2}

Fayer, M. J. 1987. Model Assessment of Protective Barrier Designs: Part II. PNL-6297, Pacific Northwest Laboratory, Richland, Washington. Irregular pages.

Abstract: A one-dimensional flow code UNSAT-H was used to study drainage of waste through a protective barrier at the Hanford Site. Model variables included soil thickness, an intermediate sand layer, reduced plant activity, revised soil hydraulic properties, and historical weather data. The two-dimensional flow code UNSAT2 was used to study subbarrier flow. Model variables included soil type, recharge rate, distance between waste and barrier edge, and soil layering.

UNSAT-H simulations showed that: 1) the thickness of soil (with no plants) required to minimize drainage depended on soil texture, and that coarse-texturedsoils minimized drainage at thicknesses less than $1.5 \mathrm{~m}, 2$ ) a sand layer between the gravel and fine soil increased drainage by about 0.1 $\mathrm{cm} / \mathrm{yr}, 3)$ reduced cheatgrass cover led to a drainage of $0.4 \mathrm{~cm} / \mathrm{yr}$ when annual precipitation was $30.1 \mathrm{~cm} /$ $\mathrm{yr}, 4)$ drainage was sensitive to hydraulic properties of the fine soil layer, and 5) use of historical yearly precipitation data increased simulated drainage 50 to $100 \%$ above predicted drainage based on average yearly precipitation.

UNSAT2 simulations showed that: 1) the finer the soil, further the waste should be from the edge; 2) fluxes past waste surrounded by sandy soil were less than $0.1 \mathrm{~cm} / \mathrm{yr}$ after only 50 years, assuming no drainage through the barrier; and 3) natural soil 
layering beyond the barrier had little effect on flow past the waste when it was surrounded by AP1 soil material.

Kev Words: EFFLUENTS AND WASTES - soil barriers, UNSAT-H model, UNSAT2 model, radioactive waste management

\section{F-3}

Fayer, M. J., W. Conbere, P. R. Heller, and G. W. Gee. 1985. Model Assessment of Protective Barrier Designs. PNL-5604, Pacific Northwest Laboratory, Richland, Washington. 59 p., App. A and B.

Abstract: A protective barrier is being considered for use at Hanford to help isolate radioactive waste from infiltration of water and from plant and animal intrusion. Computer simulations analyzed different designs of a barrier in which the top layer consisted of a fine-textured soil (composite), a finer-textured Ritzville silt loam, or a slightly coarser soil (coarse). Design variables included two rainfall rates (16.0 and $30.1 \mathrm{~cm} / \mathrm{yr}$ ) representing a dry and wet year, plant cover, gravel mixed in the surface topsoil, an impermeable boundary under the topsoil, and moving the waste form from 10 to $20 \mathrm{~m}$ from the barrier edge.

One-dimensionalsimulation indicated that each of the three soils, when used as the top layer of a barrier, could prevent drainage if plants were present. Without plants, the composite soil drained 0.4 and $3.7 \mathrm{~cm} / \mathrm{yr}$ in the dry and wet years, respectively. The Ritzville soil allowed no drainage in either year, while the coarse soil had $3.1 \mathrm{~cm}$ of drainage in the wet year. Small differences in soil hydraulic properties had large effects on drainage. Gravel in the upper $30 \mathrm{~cm}$ of soil (without plants) reduced evaporation and allowed more drainage. Varying the thickness of the soil/gravel mix from 7.5 to $30.0 \mathrm{~cm}$ had little effect on the amount of water drained. When an impermeable barrier was added under composite soil with gravel and no plants, a water table formed above the barrier. A waste form located $20 \mathrm{~m}$ from the barrier edge would not be in the path of major water flow after 500 years.

Key Words: EFFLUENTS AND WASTES computer simulation, remedial assessment, soil barriers, radioactive waste management
Fayer, M. J., G. W. Gee, and T. L. Jones. 1986. UNSAT-H Version 1.0: Unsaturated Flow Code Documentationand Applications for the Hanford Site. PNL-5899, Pacific Northwest Laboratory, Richland, Washington. Irregular pages, App. A and B.

\begin{abstract}
Waste management at Hanford has relied heavily on near-surface burial. Predicting future migration of contaminants in ground water requires a model to simulate water flow in unsaturated soils above buried wastes. UNSAT-H, developed by PNL for assessing water dynamics of near-surface waste disposal sites at Hanford, was adapted to meet this need. It will primarily predict deep drainage (i.e., recharge) as a function of environmental conditions such as climate, soil type, and vegetation. It also simulates effects of waste management practices such as use of surface barriers. UNSAT-H is a one-dimensional model using the dynamic processes of filtration, drainage, redistribution, surface evaporation, and uptake of water from soil by plants. This report describes the UNSAT-H model and includes three examples of code use.
\end{abstract}

Kev Words: EFFLUENTS AND WASTES - soil bar-riers, UNSAT-H model, radioactive waste management

\section{F-5}

Fickeisen, D. H., D. D. Dauble, D. A. Neitzel, W. H. Rickard, R. L. Skaggs, and J. L. Warren. 1980. Aquatic and Riparian Resource Study of the Hanford Reach. Columbia River. Washington. Prepared for U.S. Army Corps of Engineers, Seattle District, by Pacific Northwest Laboratory, Richland, Washington. Irregular pages.

Abstract: Construction of the proposed Ben Franklin Lock, Dam, and Reservoir, followed by impoundment, would severely affect aquatic resources in the Hanford Reach. Physical changes in critical habitat would virtually eliminate production of fall chinook salmon, steelhead trout, and mountain whitefish. Additional effects include reduced survival of salmon and steelhead produced above Hanford, and reduced production of smallmouth bass and white sturgeon in the Hanford Reach. Riparian cobble communities unique to the Hanford Reach would be lost. Most 
river islands and virtually all riparian vegetation would be inundated, and different plants would grow on the new islands and shorelines.

Kev Words: AQUATIC ECOLOGY - anadromous fish, Ben Franklin Dam (proposed), effect of darn construction, Hanford Reach, resident fish, riparian zone

\section{F-6}

Fickeisen,D. H., R. E. Fitzner, R. H. Sauer, and J. L. Warren. 1980. Wildlife Usaee. Threatened and Endangered Species and Habitat Studies of the Hanford Reach. Columbia River. Washington. Prepared for U.S. Army Corps of Engineers, Seattle District, by Pacific Northwest Laboratory, Richland, Washington. Irregularpages.

Abstract: Construction of the proposed Ben Franklin Dam on the Hanford Reach would significantly impact several plant and animals species of special concern and on a threatened species, the bald eagle. The impoundment might cause the extinction of two species (giant Columbia River limpet and great Columbia River spire snail) and the upriver run of fall chinook salmon. Nesting sites would be eliminated for many buds, including the Swainson's hawk, great blue heron, burrowing owl, and Forster's tern. Habitat and food resourcesfor several other species would be reduced, including roosting sites and a major food (salmon carcasses) of the bald eagle. Two communities of plants dependent on cobble substrate would be eliminated. Newly created riparian habitat would differ from that now present, and would enhance the production of weeds, emergent plants and willows, shorebirds, waterbirds, and songbirds as well as their predators.

Kev Words: HANFORD SITE - Ben Franklin Dam (proposed), effect of dam construction, endangered/ threatened species, Hanford Reach, riparian zone

\section{F-7}

Filby, R. H., and J. S. Stohr. 1987. "Environmental and Health Studies of Potential Impacts from Early Hanford Operations." In Waste Management '87,
Proceedines of the Symposium on Waste Management. Vol. 1 General Interest, ed. R. G. Post, pp. 347349. University of Arizona Press, Tucson, Arizona.

Contents: During 1985, Washington's Nuclear Waste Board initiated a study of potential health effects associated with past operations at Hanford. Independently, on February 27,1986, the DOE released 19,000 pages of text and data describing planned and inadvertentradionuclide releases on the Hanford Site. In response, Governor Booth Gardner of Washington, Governor Victor Atiyeh of Oregon, and the affected Indian tribes formed the "Hanford Historical Documents Review Committee." The committee was to review this material and make recommendations as to its environmental significance. This paper summarizes the results of these reviews and describesfollow-up activities now underway.

Kev Words: RADIOACTIVITY - Hanford Site releases, historical review, potential health effects, radiation data

\section{F-8}

Fitzner, R. E. 1980. Behavioral Ecology of Swainson's Hawk (Buteo swainsoni) in Washington. PNL2754, Pacific Northwest Laboratory, Richland, Washington. $64 \mathrm{p}$.

Abstract: From 1973 to 1977, the ecology of the Swainson's hawk was examined in southeastern Washington, primarily on the Hanford Site. During courtship, the male performed acrobatic aerial displays to a flying or perching female. These raptors usually built nests in trees, primarily in black locusts and Chinese elm, situated in grasslands or cultivated lands. The clutch usually had 2 eggs (range, 1 to 4 ), incubation averaged 34.5 days, and fledging averaged 43 days. Young seldom returned to nests 5 days after fledging, but depended on adults for food until migration. Home ranges averaged $9.1 \mathrm{~km}^{2}$ for males and $3.4 \mathrm{~km}^{2}$ for females, and some hawks used the same nesting site year after year. Snakes were a food staple, and insects were important after fledging. Swainson's hawks fed on smaller and more diverse prey than sympatric buteos, thereby reducing competition. Organochlorinepesticides in prey were concentrated by the hawks. 
Kev Words: TERRESTRIALECOLOGY - behavior, food and feeding, habitat use, nesting, raptors, reproduction,Swainson's hawk

\section{F-9}

Fitzner, R. E. 1980. "Impacts of a NuclearEnergy Facility on Raptorial Birds." In Workshop on Rantors and Enerev Development, eds. R. P. Howard and J. F. Gore, pp. 9-33. Idaho Chapter, The Wildlife Society, Boise, Idaho.

Abstract: Ecological studies of birds of prey on the Hanford Site reveal that: 1) several raptorial birds and the raven nest on the site, primarily because of notrespass policies and buffer zone requirements; 2) several raptors and the raven have adapted to nesting on or in manmade structures, particularly transmission towers; 3 ) artificial nest sites apparently are preferred only by a few species and allow their increase, while having no effect or negative affects on other species; 4 ) the negative effects could result when species that prefer artificial structures move into an area used by species that do not favor them; 5 ) management at energy facilities should consider the makeup of the raptor community and the use of artificial nests on manmade structures.

Kev Words: TERRESTRIAL ECOLOGY - behavior, habitat use, Hanford Site, effect of human activity, nesting, raptors, raven, relative abundance

\section{F-10}

Fitzner,R. E. 1985. "Responses of Birds of Prey to Large-ScaleEnergy Development in Southcentral Washington." In Issues and Technology in the Management of Impacted Western Wildlife, 2nd Biennial Symposium, pp. 287-294. ThorneEcological Institute, Glenwood Springs, Colorado.

Abstract: Results are presented from a 9-year study on the nesting ecology of birds of prey and the common raven at the DOE's Hanford Site. Impacts of human activity, including construction of facilities, are also discussed. Transmission poles and towers provide nesting sites for red-tailed hawks and the raven in areas previously devoid of nesting structures. Swainson's hawk were totally dependent on trees for nesting, and their nesting densities might be increased by planting trees. Construction projects are believed to have caused the Swainson's hawk to desert nests within 1 to $1.5 \mathrm{~km}$ of the activity. Overall, the Swainson's hawk, red-tailed hawk, and raven appear to have benefited from activities on the Hanford Site.

Kev Words: TERRESTRIALECOLOGY - behavior, Hanford Site, effect of human activity, nesting, raven, red-tailed hawk, Swainson's hawk

\section{F-11}

Fitzner, R. E. 1988. Cold-Blooded Vertebrates at the Pronosed Reference Repository Location in Southeastern Washington. PNL-6440, Pacific Northwest Laboratory, Richland, Washington. $15 \mathrm{p}$.

Abstract: This is one of seven environmental topical reports produced by BWIP before the project ended in late 1987. The reports provide environmental information on Hanford, a possible site for the nation's first geologic repository for radioactive wastes. This report examines cold-blooded vertebrates at five sites near the RRL. Four sites were dominated by shrubs and one lacked shrubs because of a 1984 range fire. The only lizard species, trapped at four of five sites, was the side-blotchedlizard. While this lizard was not trapped in the site dominated by spiny hopsage, it may have been missed during the relatively short study. Two species of snakes were captured, gopher snakes and green racers. The study was too brief to detect any distribution patterns.

Kev Words: TERRESTRIALECOLOGY- BWIP site, animal documentation, habitat use, reptiles, 200 Areas

\section{F-12}

Fitzner, R. E., R. A. Miller, C. A. Pierce, and S. E. Rowe. 1985. "Avian Pox in a Red-Tailed Hawk (Buteojamaicensis)." J. Wildl. Dis. 21:298-301.

Abstract: An adult male red-tailed hawk was found on the Hanford Site in May 1981. The bird could not fly and was extremely thin. Nodular proliferations occurred on both feet and cutaneous scab-like lesions were around the beak and eyes. Diagnosis indicated the bird was infected with avian poxvirus, with secondary infections of Staphyllococcus aureus and fungi. 
Kev Words: TERRESTRIALECOLOGY - disease, red-tailed hawk

\section{F-13}

Fitzner, R. E., and W. H. Rickard. 1983. "Canada Goose Nesting Performance Along the Hanford Reach of the Columbia River, 1971-1981." Northwest Sci. 57:267-272.

Abstract: Clutch size after hatching averaged 5.6, based on 1215 nests of Great Basin Canada goose along the Hanford Reach of the Columbia River from 1971 to 1981 . Successfully hatched nests averaged $82 \%$. The mean of 135 nests per year since 1971 was lower than the 215 nests per year recorded from 1953 to 1970 . The decline in nesting attempts was due to a combination of factors, with predation by coyotes being most important. The effects of coyote predation on nesting were dramatic at Lock Island.

Kev Words: TERRESTRIALECOLOGY - Canada goose, effect of predation, Hanford Reach, nesting, predation,reproduction .

\section{F-14}

Fitzner, R. E., W. H. Rickard,L. L. Cadwell, and L. E. Rogers. 1981. Raptors of the Hanford Site and Nearbv Areas of Southcentral Washington. PNL3212, Pacific Northwest Laboratory, Richland, Washington. $61 \mathrm{p}$.

Contents: Ecological features are described for five nesting owls (great homed, long-eared, short-eared, bam, and burrowing) and five nesting hawks (marsh, red-tailed, Swainson's, prairie falcon, and American kestrel) on the Hanford Site. Informationon raptors that do not nest at Hanford is given. Factors that control raptor densities and population dynamics over all seasons are discussed, and relationships of raptors at Hanford with those at other areas in southcentral Washington are evaluated.

Key Words: TERRESTRIALECOLOGY - animal documentation, habitat use, Hanford Site, hawks, nesting, owls, raptors
Fitzner, R. E., W. H. Rickard, and W. T. Hinds. 1982. "Excrement from Heron Colonies for Environmental Assessment of Toxic Elements." Environ. Monit. Assess, 1:383-386.

Abstract: Excrement cast from nests of great blue herons was collected from four colonies in Washington and Idaho. Analysis was conductedfor lead, mercury, and cadmium. The most abundant trace element was lead. Lead from samples under nests averaged $46 \mathrm{ppm}$ at Lake Chatcolet, Idaho (6 ppm in control samples), and 28 ppm near Tacoma, Washington (20 ppm in controls). Two colonies in interior Washington (one on the Hanford Reach) had substantially lower levels of lead. The associations involved a polluted watershed (Chatcolet), an interstate highway (Tacoma), and two largely agricultural areas (inland Washington).

Kev Words: TERRESTRIALECOLOGY - environmental effects, great blue heron, Hanford Reach, trace metals

\section{F-16}

Fitzner, R. E., E. T. Sipco, and R. G. Schreckhise. 1980. "American Coot Nesting and Feeding Habits in Southeastern Washington." NorthwestSci, 54: 244-252.

Abstract: Nesting and feeding habits of American coots were examined at two ponds, one at Hanford that was contaminated with low-level radioactivity and one offsite that was uncontaminated. The ponds were similar in having a stable water level, a moderate to shallow water depth, and emergent communities of cattail and bullrush. Nests from April through mid-June averaged 6.7 eggs. Hatching success was similar. Differencesin food habits were probably related to availability of food items in each pond.

Kev Words: TERRESTRIALECOLOGY - American coot, food habits, hatching success, nesting, radioactivity,reproduction, 200 Areas 
Fix, J. J., G. W. R. Endres, F. M. Cummings, J. M. Aldrich, M. R. Thorson, and R. L. Kathren. 1981. Hanford PersonnelDosimeter Supportine Studies FY-1980. PNL-3536, Pacific Northwest Laboratory, Richland, Washington. Irregular pages.

Contents: Eight studies were conducted during FY 1980 to better characterize the response of the fourchip and five-chip multipurpose dosimeters to current and future field conditions. The studies describe fundamental characteristics of the dosimeter, and provide technical documentation for Hanford's Personnel Dosimetry Program.

Topic chapters cover 1) neutron response, 2) high energy photon response, 3 ) beta and low energy photon response, 4) existing radiation field evaluations, 5) phantom positive dependence, 6) environmental factors, 7) extremity dosimeter, and 8) statistical and low dose response.

Key Words: RADIOACTIVITY - dosimeter technology, onsite workers, radiation protection

\section{F-18}

Fix, J. J., J. M. Hobbs, P. L. Roberson, D. L. Haggard, K. L. Holbrook, M. R. Thorson and F. M. Cunningham. 1982. Hanford Personnel Dosimeter Supporting Studies FY-1981. PNL-3736, Pacific NorthwestLaboratory, Richland, Washington. Irregular pages.

Contents: Eight studies were conducted during FY 1981 to enhance the current multipurpose dosimeter used at Hanford, or possibly a redesigned system. The Personnel Dosimetry Program determines nonpenetrating, penetrating,fast neutron, and slow neutron dose components. Interpretation of doses requires an understanding of dosimeter design, readout, dose algorithm, and calibration methods.

Topic chapters cover 1) dependence of dose calculations on reader characteristics, 2) assessment of existing and proposed dosimetry calibration techniques, 3) Hanford field measurements and field dosimeter response, 4) dose calculation algorithm upgrade analysis, 5) dosimeterenergy response measurements, 6) dosimeter modification and testing, and 7) dosimeter annealing. Significantobservations from the studies, including possible modifications to the dosimeter system, are given.

Kev Words: RADIOACTIVITY - dosimeter technology, onsite workers, radiation protection

\section{F-19}

Fix, J. J., K. L. Holbrook, and K. L. Soldat. 1983. Hanford Beta-Gamma Personnel DosimeterPrototypes and Evaluation. PNL-4481, Pacific Northwest Laboratory, Richland, Washington. 54 p., App. A.

Abstract: Upgraded and modified dosimeter prototypes were evaluated for possible use at Hanford as a primary beta-gamma dosimeter. In general, the current dosimeter can be upgraded by using individual chip sensitivity factors to improve precision and an improved algorithm to minimize bias. The existing neutron capability of the dosimeter could be retained. Better performance to beta-gammaradiation can be achieved by modification so that four of five chip positions are devoted to calculating doses instead of the currently used two chip positions. Low energy beta response can be improved in the current dosimeter and all prototypes by eliminating the security credential. Further improvement can be obtained by incorporating the 15-mil thick TLD-700 chips. Most personnel exposures at Hanford are from beta-gammaradiation.

Kev Words: RADIOACTIVITY - dosimeter technology, onsite workers, radiation protection

\section{F-20}

Fogel, P. A. 1983. UNC Nuclear Industries Reactor and Fuels Production Facilities 1982 Effluent Release Report. UNI-2358, UNC Nuclear Industries, Richland, Washington. 24 p.

Abstract: All significant discharges from UNC facilities in CY 1982 were reported. Results indicated that: 1) no technical specification limit was exceeded; 2) total curies of ${ }^{41} \mathrm{Ar}$ from the $116 \mathrm{~N}$ stack was $75 \%$ higher than in 1981, but averaged the same per operating hour; 3) total curies of ${ }^{131}$ I released from the $\mathrm{N}$ Springs were slightly less than in 1981; 4) releases of other "indicator" radionuclides remained consis- 
tent with recent releases. Nonradioactive releases from N Reactor during CY 1982 were consistent with recent release levels.

Kev Words: HANFORD SITE - effluents and emissions, environmental monitoring, nonradioactive releases, $\mathrm{N}$ Reactor, radioactivity, 100 Areas

\section{F-21}

Forrester, H. A., K. A. Gasper, R. E. Isaacson, A. H. Lu, S. J. Phillips, R. C. Routson, and W. W. Schultz. 1982. The DN Well Freauencv ResponseEquation: A Critical Review of its Basis and Derivation. RHORE-EV-11, Rockwell Hanford Operations, Richland, Washington. $30 \mathrm{p}$, App. A and B.

Abstract: Dry wells have been drilled around each of the 149 single-shell, underground waste tanks oin the Hanford Site. The recent "Dry Well Radioactivity Response Equation" (DWRRE) (RHO-ST-34) is a scientifically valid and technically correct basis for establishing the frequency of monitoring radiation levels in these dry wells. This is the main conclusion of a special review committee commissioned from Rockwell for an independent, critical, and comprehensive technical analysis of the scientific and mathematical logic and methods underlying the equation. As part of the deliberations, an analytical model (diffusion model) of plume movement from a leaking single-shell tank was derived by solving the partial differentialequations governing the motion of fluids through soils. Of significance, the diffusion model yielded results essentially the same as those produced by the DWRRE.

Kev Words: EFFLUENTS AND WASTES - assessment, DWRRE model, single-shell tanks, tank leak detection, 200 Areas

\section{F-22}

Freshley, M. D., and M. J. Graham. 1988. Estimation of Ground-Water Travel Time at the Hanford Site: Description. Past Work, and Future Needs. PNL-6328, Pacific Northwest Laboratory, Richland, Washington. $57 \mathrm{p}$.

Abstract: For this report, contaminant arrival time (or travel time) was defined as the average time for ground water or contaminants to move from point $\mathrm{A}$ to point $\mathrm{B}$ along a particular flow path. Various estimates of travel time for the unconfined aquifer beneath the Hanford Site were reviewed on the basis of ground-water monitoring data, local measurements of velocity, and modeling. Published estimates varied widely. Rather than a single travel time, estimates depended on starting location, conditionsin the aquifer, and whether the estimate was for ground water or a specific contaminant. More characterization and modeling is necessary to avoid future confusion about ground-water travel times at Hanford.

\section{Kev Words: GEOLOGY AND HYDROLOGY -} geohydrologic assessment,flow rates, travel times, unconfinedaquifer

\section{F-23}

Friedli,E. A. 1987. Interim Facilities and Services Profile. Benton and Franklin Counties, Working Draft. BWIP Repository Proiect. PNL-6384 (BHARC-800/87/027), Pacific NorthwestLaboratory, Richland, Washington. $33 \mathrm{p}$.

Contents: This is one of five Socioeconomic Profile Reports produced by BWIP before the project ended in late 1987. The reports provide community information associated with Hanford, a possible site for the nation's first repository for radioactive wastes. This report provides a general background of interim facilities and services available in Benron and Franklin counties. It discusses quality assurance; the collection, analysis, and control of data; the database system; and profile data. Profile data include information on school districts, libraries, police and sheriff departments, courts, fire departments, health facilities, United Way assistance programs, streets and roads, waste and waste treatment, and parks and recreation. Technical issues and data requirements are identified.

Kev Words: SOCIOECONOMICS - Benton/ Franklin counties, BWIP, current conditions, information needs, services and facilities

\section{F-24}

Friedli,E. A., D. I. Herborn, C. D. Taylor, and K. M. Tomlinson. 1988. ProjectCharacteristics Monitoring Report. BWIP Repository Project. PNL-6505 
(BHARC-800/88/004), Pacific NorthwestLaboratory, Richland, Washington. Irregular pages.

Abstract: This report complies with provisions of the Nuclear Waste Policy Act of 1982 (NWPA), and provides local and state agencies with information on the BWIP at Hanford. The report covers May 26, 1986 to February 1988, and includes data on employment, salaries, purchases, taxes and fees paid, worker survey results, and a summary of interviews on project closedown. Amendments to the NWPA in 1987 required all work on BWIP other than site reclamation to stop as of March 22,1988. Abrupt termination surprised the DOE, state and local officials, and the BWIP work force.

Site characterization began in May 1986 with 578 workers already involved. The work force expanded to 789 direct BWIP workers in September 1987, and decreased to 694 as of December 1987. When both direct and indirect workers were included, the work force changed from 798 to 1,240 to 1,145 , respectively. About 1,145 jobs, encompassing monthly salaries of about \$3.1 million, would be eliminated with closure of $\mathrm{B} \mathrm{W}$. The taxes and fees paid by contractors averaged about $\$ 45,000$ per month. The "average BWIP worker" had been with the same employer about 5 years and worked on BWIP activities about 1 year. Most workers realized they would have to move from the Tri-Cities, but preferred to stay. They considered economic diversion a false hope (too late to help), retraining as unrealistic (they were already highly trained), and loss of home equity as their major concern (a large economic loss).

Kev Words: SOCIOECONOMICS - effect of BWIP closure, socioeconomicimpacts, employment, NWPA amendments, taxes and fees, work force

\section{F-25}

Friedli, E. A., and P. R. Yost. 1987. Summary Report: Worker Survev August 1987. Working Draft. BWIP Repository Project. PNL-6431 (BHARC-800/ 87/034), Pacific NorthwestLaboratory, Richland, Washington. $38 \mathrm{p}$.

Abstract: A survey of workers in the Hanford area during August 1987 enabled better understanding of the potential effects of BWIP on the state and local area. Report topics include employment, migration status, place of residence, transportation to work, housing type, household structure, and basic demographic data. Generally, the average B W worker had been with the same employer about 5 years, and had worked on BWIP activities about 1 year. This worker owns his (her) home in Richland because it is close to work, and lives with his (her) family of two to four people. The "average worker" (a statistical entity) is a white male between 30 and 39 years old.

Key Words: SOCIOECONOMICS - BWIP, demography, socioeconomicimpacts, employment, work force

\section{F-26}

FritzPatrik, V. F., D. R. Brown, J. L. Buelt, S. E. King, B. A Napier, K. H. Oma, D. J. Silviera, and C. L. Timmerman. 1984. "In-Situ Vitrification of Transuranic Wastes: Systems Evaluation and Application Assessment." In Waste Management '84. Proceedings of the Sumnosium on Waste Management. Vol. 1 Waste Policies and Promams, High-Level Wastes, ed. R. G. Post, pp. 665-671. University of Arizona Press, Tucson, Arizona.

Abstract: In situ vitrification(ISV) is an emerging technology suitable for stabilization of radioactive wastes. In just under three years, ISV moved from a laboratory concept to an achievable reality. A radioactive make-up site of TRU wastes and mixed fission products has been stabilized by the pilot-scale system. In this test, about $25 \mathrm{~kg}$ of contaminated soil containing about $600 \mathrm{nCi} / \mathrm{g}$ of ${ }^{239} \mathrm{Pu} /{ }^{241} \mathrm{Am}$ was successfully vitrified with no release of radionuclides. The ISV tests were supplemented with calculations of public and occupational exposure that showed releases fall below limits set by the federal government for both routine and accident conditions. Performance analysis has verified that the process was effective in terms of preventing movement of radionuclides into the biospherein the distant future (1000 and 10,000 years) under several intrusion scenarios. Cost analyses showed that, for both Hanford and a generic site, processing costs were less than disposal costs for low-level wastes at DOE disposal sites.

Kev Words: EFFLUENTS AND WASTES - in-situ vitrification, radioactive wastes, remedial studies, vitrification technology, waste disposal 
Fruchter, J. S., C. E. Cowan, D. E. Robertson, D. C. Girvin, E. A. Jenne, A. P. Toste, and K. H. Abel. 1985. RadionuclideMigration in Groundwater, Annual Report for FY 1983. NUREG/CR-3712 (PNL-5040), U.S. Nuclear Regulatory Commission, Washington, D.C. 122 p., App. A through C.

Abstract: Data on migration of radionuclides in ground water were collected for several years at a low-level disposal site (at Hanford). Most radionuclides in the influent water were removed in the disposal basin and trench, probably by sorption onto the soil. Only trace amounts of several radionuclides migrated to seepage springs. The most mobile forms included the isotopes of cobalt, technetium, iodine, ruthenium, antimony, iron, and nickel, and they were anionic and nonionic charges. Typically, radionuclides entering in particulateform concentrated near the upper end of the trench, while those in soluble form spread more widely. In situ Kd values and the velocity of the radionuclide front were estimated from well samples. Low molecular weight hydrophilic organic compounds in the influent and ground waters consisted of carboxylic acids, generally at ppb levels and representing bioorganic and microbial diagnoses products. Organic acids in the trench water appear to arise from the rich biological activity in the trench mud.

A potentially important mechanism for retarding or removing radionuclides from ground water was adsorption onto amorphous manganese and iron oxides and onto organic compounds with high affinity for cationic and anionic forms of the radionuclides. Studies with neptunium supported the hypothesis that amorphous iron oxide fractions in the soil determined the adsorption behavior of the neptunyl oxy cation $\mathrm{NpO}_{2}^{+}$. Geochemical modeling showed that the mobile species of radionuclides are the anionic and nonionic oxy- and hydroxy complexes, although organic complexes may be important mobile species for iron, zinc, and cobalt. Radionuclides that occur in ground water primarily as the uncomplexed cation (such as cesium, cerium, and manganese) appear to be the most greatly retarded.

Kev Words: RADIOACTIVITY - behavior in soil, ground-water transport, physicochemical properties, radionuclides, 100 Areas
Fruchter, J. S., C. E. Cowan, D. E. Robertson, D. C. Girvin, E. A. Jenne, A. P. Toste, and K. H. Abel. 1985. RadionuclideMigration in Ground Water, Final Report. NUREG/CR-4030 (PNL-5299), U.S. Nuclear Regulatory Commission, Washington, D.C. $41 \mathrm{p}$.

Abstract: Data on migration of radionuclides in ground water were collected for several years at a low-level disposal site (at Hanford). Most radionuclides were removed in the disposal basin and trench by either precipitation or adsorption mechanisms. However, ${ }^{60} \mathrm{Co},{ }^{106} \mathrm{Ru}$, and ${ }^{125} \mathrm{Sb}$ showed greater than expected mobility. The elements of these three isotopes were in either anionic or nonionic chargeforms. Complexes with both natural and manmade organics were implicated in the increased mobility, particularly with ${ }^{60} \mathrm{Co}$. Ruthenium- $103,{ }^{60} \mathrm{Co}$, and ${ }^{125} \mathrm{Sb}$ were associated with organics of higher molecular weights, particularly humic and fumic acids with molecular weights higher than 1000 . Studies also proved the hypothesis that the adsorption behavior of ${ }^{235} \mathrm{~Np}$ on soils of the site was dominated by adsorption on iron hydroxide. Geochemical modeling of data on chemical and charge form showed the ground water to be in equilibrium with several solids that could be important in controlling concentrations of trace elements and radionuclides.

Key Words: RADIOACTIVITY - behavior in soil, ground-water transport, physiochemical properties, radionuclides, 100 Areas

\section{F-29}

Fuchs, M. R., and G. R. Cox. 1983. Eactors Affecting Choice of Plant Species for Revegetation on the Hanford Site. RHO-LD-155, Informal Report, Rockwell Hanford Operations, Richland, Washington. 20 p., App. A through D.

Abstract: In the 100 Areas, three sites were evaluated with perennial grass stands composed largely of Siberian wheatgrass-thickspikewheatgrass, Indian ricegrass, and Sandberg's bluegrass, respectively. Objectives were to determine: 1) if soil conditions influenced establishmentof these stands, 2) the extent of these perennial grasses on the Hanford Site 
before human influences, and 3) whether these perennials could be established on other sites to be stabilized.

The depth of the soil to coarse sediments, the soil texture, and the percentage of gravel appeared to affect vegetation communities. Siberian, thickspike, and crested wheatgrass should be used for revegetation on deep, fine-textured soils low in gravel. Indian rice-grass, needle and thread grass, Sandberg's bluegrass, and sand dropseed should be used for revegetation on shallow, coarse-textured soils or gravelly soils. Success in stabilization/revegetation programs will be greater if deep, fine-texture soils are planted.

Kev Words: TERRESTRIALECOLOGY - Hanford Site, revegetation, Indian ricegrass, reclamation, Sandberg's bluegrass, Siberian wheatgrass, thickspike wheatgrass.

\section{G-1}

Gaines, W. E. 1987. Secondary Production of Benthic Insects in Three Cold-Desert Streams. PNL6286, Pacific Northwest Laboratory, Richland, Washington. 39 p., App. A.

Abstract: Production of aquatic insects was studied in an offsite stream, Snively Springs, and Rattlesnake Springs (both at Hanford). Baetis sp. (mayflies) accounted for $42 \%$ of all insects and $25 \%$ of biomass in Snively Creek. Simulum sp. (blackflies) and Baetis sp. made up $74 \%$ of all insects and $55 \%$ of biomass in RattlesnakeSprings. In Snively and Rattlesnake springs, collectors were the most abundant functional group while herbivores and detritivores were the most abundant trophic level. Dipterans (midges and blackflies) were the taxa accounting for 40 to $70 \%$ of total community production. Insects that developed rapidly and produced multiple cohorts were very important in cold-desert streams, and much production was due to insectsfeeding on detritus.

Key Words: AQUATIC ECOLOGY, aquatic insects, insect production, secondary production, Snively Springs (Creek), Rattlesnake Springs
Gano, K. A. 1980. "Mortality of the Harvester Ant (Pogonomyrmex owyheei) After Exposure to ${ }^{137} \mathrm{Cs}$ Gamma Radiation." Environ. Entomol, 10:39-44.

Abstract: Harvester ants were irradiated with $3.5 \mathrm{kR}$ to $268 \mathrm{kR}$ of gamma radiation from ${ }^{137} \mathrm{Cs}$ and maintained at simulated summer $\left(27^{\circ} \mathrm{C}\right)$ and winter $\left(7^{\circ} \mathrm{C}\right)$. After 30 days, the cool series was warmed to $27^{\circ} \mathrm{C}$ and observed for mortality along with the warmed series. Though mortality was delayed in the cool series, each series reached $50 \%$ mortality at similarrates.

Because the harvester ant is extremely tolerant of experimental irradiation, it is unlikely that ant colonies dwelling among low-level waste sites at Hanford will be deleteriously affected by onsite radiation. This species is able to tunnel to a depth well within the range of some buried wastes. These harvester ants are potential transportersof buried wastes, and should be considered in waste management practices.

Kev Words: TERRESTRIALECOLOGY - biotransfer, burrowing, harvester ant, radioecology, waste burial sites

\section{G-3}

Gano, K. A. 1983. Colonv Densitv and Activity Pattems of the Ant Camponotus semiterstaceous (Hymenoptera: Formicidae) in a Shrub Stepoe Community. M.S. Thesis, Washington State University, Pullman, Washington. $39 \mathrm{p}$.

Abstract: Data were obtained on colony densities and aboveground activity of an ant at the ALE Reserve, Hanford Site. Three 25.5-ha sites were studied, two with sagebrush and bluebunch wheatgrass as the dominant vegetation, and one lacking sagebrush but with understory after a past wildfire. Colonies averaged 0.088 and 0.048 per $\mathrm{m}^{2}$ on unburned sites, and 0.028 on the burned site. Most nest entrances (75\%) were near sagebrush stems. Aboveground activity commenced just after sunset when light intensity decreased to 2.5-1.0 foot-candles, and ended just before sunrise. Aboveground activity ceased when seasonal temperatures dropped to between $1.7^{\mathrm{N}}$ and $3.9^{\circ} \mathrm{C}$ in surface soil. 
Kev Words: TERRESTRIALECOLOGY - ants, behavior, population density, habitat use

\section{G-4}

Gano, K. A., and W. H. Rickard. 1982. "Small Mammals of a Bitterbrush-CheatgrassCommunity." Northwest Sci, 56:1-7.

Abstract: Small mammals were live-trapped in burned and unburned areas of a bitterbrush-cheatgrass community from 1974 to 1979 . The shrubdominated, unburned area supported about three times as many small mammals as the cheatgrassdominated, burned area. Species composition was similar in both areas, with the exception of Townsend's ground squirrels captured on the unburned area. Other species captured were the Great Basin pocket mouse, deer mouse, northern grasshopper mouse, and the western harvest mouse.

Kev Words: TERRESTRIALECOLOGY - animal documentation, habitat use, rodents/small mammals

\section{G-5}

Gano, K. A., and L. E. Rogers. 1983. "Colony Density and Activity Times of the Ant Camponotus semitestaceus (Hymenoptera: Formicidae) in a Shrub Steppe Community." Ann. Entomol. Soc. Am. 76:958-963.

Abstract: Colony densities and aboveground activities of ant colonies were examined on the Hanford Site. Colony densities averaged 0.088 and $0.048 / \mathrm{m}^{2}$ on two sagebrush-bunchgrasssites, and $0.028 / \mathrm{m}^{2}$ on a burned site. Most $(75 \%)$ of the nest entrances were along the stems of sagebrush. Activity above the ground commenced shortly after sunset, when light intensities dropped to 2.5 to 1.0 foot-candlesand ended just before sunrise. When temperatures at the soil surface dropped to $1.7^{\prime \prime}$ to $3.9^{\circ} \mathrm{C}$, all activity above the ground stopped, irrespective of light intensity.

Key Words: TERRESTRIAL ECOLOGY - ants, behavior, population density, habitat use
Gano, K. A., J. R. Skalski, J. L. Badden, and L. E. Rogers. 1983. TheEffects of Habitat on Recapture Probabilities of Small Mammals. PNL-10159, Pacific Northwest Laboratory, Richland, Washington. $19 \mathrm{p}$.

Abstract: Populations of small mammals occupying old-field (cheatgrass) and undisturbed sagebrushbunchgrass communities on the Hanford Site were compared during 1979 and 1980. Seven species were captured. The Great Basin pocket mice was the dominant species in both habitats, and the only species with enough captures to validate abundance estimates. Overall, pocket mice were captured most frequently in sagebrush/bunchgrass communities.

Key Words: TERRESTRIAL ECOLOGY - Great Basin pocket mouse, habitat use, relative abundance, rodents/small mammals

\section{G-7}

Gano, K. A., and J. B. States. 1982. Habitat Requirements and Burrowinn Depths of Rodents in Relation to Shallow Waste Burial Sites. PNL-4140, Pacific Northwest Laboratory, Richland, Washington. $23 \mathrm{p}$.

Contents: This report reviews the literature and summarizes information on factors affecting habitat selection and maximum burrowing depths of small mammals likely to inhabit waste burial sites in arid and semi-arid regions of the western United States. Waste repositories could be designed to exclude deep-burrowing rodents by creating unattractive habitat over the site. Habitat requirements of each group of small mammals are summarized, along with general site modifications that might deter inhabitalion.

Kev Words: TERRESTRIALECOLOGY - burrowing, habitat use, rodents/small mammals, waste burial sites 
Gee, G. W. 1987. Recharge at the Hanford Site:

Status Report. PNL-6403, Pacific Northwest Laboratory, Richland, Washington. Irregular pages, App. A.

Abstract: Data from field programs to evaluate recharge and other water balance components on the Hanford Site since 1970 indicate that there is a wide range of recharge rates dependenton specific site conditions. Minimum recharge apparently occurs where soils are fine-textured and surfaces are covered with deep-rooted plants. Maximum recharge occurs where coarse soils or gravels exist at the surface and soils are kept bare. Recharge can occur where shallow-rooted plants predominate, particularly where soils are coarse. Data from lysimeters located in the 200 Areas and 300 Area are presented to support these conclusions.

Rechargeestimates have been made with simulation models. A U.S. Geological Survey model has calculated recharge rates from near zero to an average of about $1 \mathrm{~cm} / \mathrm{yr}$ for the Hanford Site. Other models also predict very low recharge rates, but do not account for site-specific soils and plant covers. UNSAT-H, a deterministic model developed for the Hanford Site, appears to be the best available code for estimating recharge on a site-specific basis. Calibration of UNSAT-H is under way, with compilation of field data from soil and plant covers under variableclimatic conditions. No waste storage sites at Hanford have been directly monitored for recharge.

\section{Key Words: GEOLOGY AND HYDROLOGY -} lysimeter data, lysimeter performance, ground-water recharge, unsaturated (vadose) zone, UNSAT-H model, water balance

\section{G-9}

Gee, G. W., and A. C. Campbell. 1980. Monitoring and Phvsical Characterization of Unsaturated Zone Transport. Laboratorv Analysis. PNL-3304, Pacific Northwest Laboratory, Richland, Washington.

Abstract: Sorption near-surface sediments at Hanford were examined in unsaturated soil columns. The sorption of mobile nuclides such as tritium, cobaltEDTA, and technetium could be measured with greater precision in unsaturated column tests than with batch methods. While the two methods were in general agreement, adsorption coefficient $(\mathrm{Kd})$ values for tritium, cobalt-EDTA, technetium, and iodine were less variable and better defined with unsaturated column tests. Kd values for strontium from unsaturated column tests agreed well with results from batch tests. Flow rates within the range of 2 to $50 \mathrm{~cm} /$ day had little effect on sorption of nuclides. Changes in soil saturation from 56 to $31 \%$ also had little effect on nuclide sorption. For layered sediments, the effective sorption was effectively controlled by sorption features of the most sorbing layer.

Kev Words: RADIOACTIVITY - adsorption, behavior in soil, distribution coefficients, Kd values, physicochemical properties, radionuclides, surface soil

\section{G-10}

Gee, G. W., A. C. Campbell, P. J. Wierenga, and T. L. Jones. 1981. Unsaturated Moisture and Radionuclide Transport: Laboratory Analvsis and Modeling. PNL-3616, Pacific Northwest Laboratory, Richland, Washington. Irregularpages.

Abstract: Transport of radionuclides through unsaturated media (simulating Hanford soil) was studied in a two-parameter,convection-dispersive model and a four-parameter,mobile-immobilewater model. Both models adequately described the movement of tritium and strontium through small $(5-$ by $27.5-\mathrm{cm})$ columns, and the movement of tritium through a large $(0.5-$ by $1.7-\mathrm{m})$ column. The dispersion coefficients were sensitive to changes in both velocity and water column. The convectiondispersion model was most sensitive to changes in experimentalscales. These models were relatively successful in describing the rapid flush of ${ }^{85} \mathrm{Sr}$ from a column initially leached with a low salt solution, followed by a high salt solution (the "snowplow effect"). The mobile-immobile water model predicted the initial release of strontium most accurately. Both models confirm enhanced mobility of ${ }^{85} \mathrm{Sr}$ with increased salt in leaching solutions.

Key Words: RADIOACTIVITY - leachability, computer modeling, strontium, tritium, radionuclide movement 
Gee, G. W., and P. R. Heller. 1985. Unsaturated Water Flow at the Hanford Site: A Review of Literature and Annotated Bibliography. PNL-5428, Pacific Northwest Laboratory, Richland, Washington. 42 p., App. A

Abstract: Onsite reports were reviewed for information to help determine if the unconfined aquifer at Hanford was recharged by natural precipitation. Moisture at depth in Hanford sediments is generally low, ranging from 2 to $7 \mathrm{wt} \%$ in coarse- and mediumtextured sands, and 7 to $15 \mathrm{wt} \%$ in silts. Water in deep sediments may slowly drain to the water table at a rate depending on the hydraulic conductivity of unsaturated sediments. Lysimeter studies in the 200 Areas, 1971 through 1977, indicated that recharge can be estimated with precision of only $+/-2.6 \mathrm{~cm} /$ year for a given set of readings, and that water did not move deeper than 5 m over the 6-year test. Studies in the 300 Area 1979 thorough 1984 indicated that water moves below the root zone, and recharge rates from bare soil exceeded $5 \mathrm{~cm} / \mathrm{yr}$ for the past 2 years. Tritium sampling of unsaturated sediments indicated that infiltration water had moved to depths of $5 \mathrm{~m}$ by 1969. Soil hydraulic and evapotranspiration values have not been measured with sufficient accuracy to be used in models to predict rechargerates.

\section{Key Words: GEOLOGY AND HYDROLOGY -} geohydrologic assessment, evapotranspiration, surfacerecharge, unsaturated (vadose) zone, soil moisture

\section{G-12}

Gee, G. W., and T. L. Jones. 1985. Lvsimeters at the Hanford Site: Present Use and Future Needs. PNL5578, Pacific Northwest Laboratory, Richland, Washington. $44 \mathrm{p}$.

Contents: To evaluate onsite characteristicsfor disposal of radioactive waste at Hanford, unsaturated flow must be modeled and data on water movement in the unsaturated (vadose) zone must be compiled. Lysimeters enable direct measurement or estimation of water balance features such as soil-waterstorage changes, evapotranspiration, and drainage at given sites. This report describes six major lysimeter facilities at Hanford: 1) 200 East Area Rockwell lysimeters, 2) biointrusion lysimeters, 3) buriedwaste test facility lysimeters,4) commercial-waste test facility lysimeters,5) grout waste test facility lysimeters, and 6) ALE Reserve lysimeters. Weighing lysimeters in the 300 Area and at ALE Reserve now provide the only evapotranspiration data available on the Hanford Site. Needs for continued lysimeter studies at Hanford are identified.

\section{Key Words: GEOLOGY AND HYDROLOGY -} Hanford Site, lysimeter facilities, unsaturated (vadose) zone, water balance

\section{G-13}

Gee, G. W., and R. R. Kirkham. 1984. Arid Site Water Balance: EvapotranspirationModeling and Measurement. PNL-5177,Pacific Northwest Laboratory, Richland, Washington. 38 p., App. A.

Abstract: Management of low-level waste requires modeling to predict the transport of water and radionuclides through unsaturated sediment. Such transport is likely the dominant pathway for migration of contaminants from most shallow burial sites. Field measurements on the Hanford Site during 1983 and 1984 (two "wet years") confirmed that water moves below the root zone and is lost to deep drainage during periods of low evapotranspiration (i.e., winter). Over $10 \mathrm{~cm}$ of drainage occurred from bare sandy soil and $5 \mathrm{~cm}$ from a grass-coveredfield in one year.

Water balance was estimated with UNSAT-1D, a model that describes transient unsaturated flow in soils. Plant evapotranspiration was simulated with a time-dependent transpiration function for cheatgrass. Grass roots were not found below $1 \mathrm{~m}$. Hence, moisture changes below $1 \mathrm{~m}$ were due primarily to drainage. Upward capillary flow was negligible because the soil was coarse sand and the water table was below $10 \mathrm{~m}$. Waste management at arid sites in the western United States will require special attention to soil characteristics, precipitation distribution, and plant cover to adequately predict sitespecific recharge rates.

\section{Key Words: GEOLOGY AND HYDROLOGY -} drainage, evapotranspiration, precipitation effects, surface recharge, unsaturated (vadose) zone 
Gephart, R. E., and S. M. Price. 1983. "Geohydrologic Characterizationand Qualification of a HighLevel Waste Site in Basalts." In Waste Management '83, Proceedings of a Svmposium on Waste Management. Vol, II. ed. R. G. Post, pp. 151-158. University of Arizona Press, Tucson, Arizona.

Abstract: Geohydrologicstudies are under way on the Hanford Site to characterize Columbia River

Basalt for possible disposal of nuclear wastes. Findings indicate that the Pasco Basin, including the site of the RRL, has deformed slowly (averaging $<0.1$ $\mathrm{mm} / \mathrm{yr}$ ) and will continue to deform slowly along existing geologic structures. Most ground water in deep basalts moves laterally through parts of the basalt flow tops under low (about $10^{4} \mathrm{~m} / \mathrm{m}^{2}$ ) hydraulic gradients. The flow tops are separated by basalt flow interiors having hydraulic conductivitiesin the range of 10 to 11 to 10 to $13 \mathrm{~m} / \mathrm{s}$. Using site-specific data, modeling indicates that travel times for ground water to the accessible environment are $>10,000$ years. Because the major radionuclides have limited solubilities, and the basalt has sorption capacity, most radionuclides are effectively immobilized in the basalt.

Kev Words: GEOLOGY AND HYDROLOGY basalt formations, ground-water movement, hydraulic conductivity,Pasco Basin, subsurfacecharacteristics

\section{G-15}

Gephart, R. E., S. M. Price, R. L. Jackson, and C. W. Myers. 1984. "Geohydrologic Factors and Current ConceptsRelevant to Characterizationof a Potential Nuclear Waste Repository Site in Columbia River Basalt, Hanford Site, Washington." In Scientific Basis for Nuclear Waste Management VII, Materials Research Society Symposia Proceedings Vol. 26, ed. G. L. McVay, pp. 85-94. North-Holland, New York.

Abstract: Geologic features may affect movement of ground water in basalt at the Hanford Site. These features include pathway flow interiors, flow contacts, and bedrock structural discontinuities. Four concepts describe movement of ground water in basalt. Differences between concepts generally focus on the degree of vertical leakage through basalt flow interiors. The existing geohydrologic data base is insufficient to conclusively support one groundwater-flow concept over another. However, available data indicate the existence of distinct ground-waterflow systems having relatively low vertical leakage under low hydraulic heads, except where structures are discontinuous.Characterizationactivities are now under way to reduce uncertainties.

\section{Key Words: GEOLOGY AND HYDROLOGY -} basalt formations, BWIP site, geohydrologic assessment, ground-waterdata base, ground-water movement,

\section{G-16}

Gibson, M. W., D. M. Gerboth, and B. B. Peters. 1987. "Pretreatment of Hanford PUREX Plant FirstCycle Waste." In Waste Management' 87. Proceedings of the Symposium on Waste Management. Vol, 1 General Interest, ed. R. G. Post, pp. 603-608. University of Arizona Press, Tucson, Arizona.

Abstract: A process was developed to pretreat neutralized, first-cycle, high-level waste from the PUREX plant at Hanford. The process separates solids from supernate liquid, which contains soluble salts. The solids, including most of the fission products and transuranic elements, may then be vitrified for disposal while the low-level supernate stream may be processed into a less expensive grout waste form. The process includes ion exchange treatment of the separated supernate stream to remove radiocesium. A flow sheet based on these operations was completed to support a planned demonstration at the B Plant canyon facility at Hanford.

Key Words: EFFLUENTS AND WASTES - B plant, high-level wastes, PUREX Plant, radioactive liquids, technology change

\section{G-17}

Gilbert,E. S. 1980. "Mortality of Hanford Radiation Workers," pp. 119-127. In Health Implications of New Energy Technologies, eds. W.N. Rom and V.E. Archer, pp. 119-127. Ann Arbor Science Publishers, Ann Arbor, Michigan. 
Abstract: Mortality from all causes of white males employed at Hanford for at least two years was $75 \%$ of that expected on the basis of U.S. statistics. Mortality from cancer was $85 \%$ of that expected. Myeloid leukemia, the disease most strongly associated with exposure to radiation, was not correlated with external radiation exposure of Hanford workers. These results were consistent with current estimates of radiation effects.

Two specific cancers, multiple myeloma and to a lesser extent cancer of the pancreas, were positively correlated with radiation exposure. 'These associations warrant continued attention, but one or both may be false positive results from among the 15 cancer sites tested. Other occasional exposures may have a confounding role, and death-certificate diagnosis of cancer of the pancreas is not very reliable. The correlations were based on a small number of deaths (three each for multiple myeloma and cancer of the pancreas) with cumulativeexposure greater than $15 \mathrm{rem}$. Observation and analysis will continue.

Kev Words: RADIOACTIVITY - cancer incidence, onsitc (Hanford) workers, potential health effects, statisticalanalyses

\section{G-18}

Gilbert,E. S. 1985. "The Hanford Study - A Review of Its Limitations and Controversial Conclusions." In Proceedines of the 1984 Statistical Svmposium on National Energy Issues, pp. 96-110. PNL-SA-13085. Pacific Northwest Laboratory, Richland, Washington.

Abstract: The Hanford data set (on radiation effects) has attracted attention, primarily of the analyses conducted by Mancuso, Stewart, and Kneale (MSK). These investigators claimed that the Hanford data provide evidence that our current estimates of cancer mortality from exposure to radiation were too low. Thus, they advocated replacing estimates based on populations exposed at relatively high levels (such as the Japanese survivors of the atom bomb) with estimates based on the Hanford data. This paper shows that the only evidence of association of radiation data and mortality provided'by the Hanford data is a small excess of multiple myeloma, and that this data set is not adequate for reliable risk estimation. Confidence limits for risk estimates are very wide, and the data are not adequate to differentiate among models. This paper provides a critique of the more recent MSK analyses, which claim to provide adequate models and risk estimates.

Kev Words: RADIOACTIVITY - onsite (Hanford) workers, potential health effects, risk assessment, statisticalanalyses

\section{G-19}

Gilbert,E. S., and G. R. Petersen. 1985. "A Note on Job Related Mortality Risks of Hanford Workers and Their Relation to Cancer Effects of Measured Doses of External Radiation." Brit___Ind_Med. 42:137139.

Abstract Some results of recent, onsite analyses of data relating to exposure of Hanford workers to external radiation were given. Comparisons were made with techniques and conclusions reached in a paper by G.W. Kneale, T.F.Mancuso, and A.M. Stewart (1984. "Job-Related Mortality Risks of Hanford Workers and Their Relation to Cancer Effects of Measured Doses of External Radiation." Br. J. Ind. Med, 41:9-14.) Based on the authors' analyses and on scrutiny of the Kneale et al. paper, there seemed to be no compelling reason to believe that Hanford data were inconsistent with current estimates of radiation risks.

Kev Words: RADIOACTIVITY - onsite (Hanford) workers, potential health effects, risk assessment, statistical analyses

\section{G-20}

Gilbert,E. S., G. R. Petersen, and J. A. Buchanan. 1989. "Mortality of Workers at the Hanford Site: 1945-1981." Health Phvs, 56:11-25.

Abstract: Analyses of mortality of workers at the Hanford Site were updated to include an additional 3 years of data (1979 to 1981). Deaths in the State of Washington from 1982 to 1985 were also evaluated. Hanford workers continued to exhibit the "healthy worker effect" strongly, with death rates substantially below those of the general U.S. population. Comparisons by level of radiation exposure within the Hanford worker population provided no evidence of a 
positive correlation of radiation exposure and mortality from all cancers combined or of mortality from leukemia. Estimates of cancer risk from radiation were negative. Confidenceintervals were wide, indicating that the data were consistent with no risk and with risks several times larger than estimates provided by major groups concerned with risk assessment(radiation exposure). Of 18 categories of cancer analyzed, a correlation of borderline statistical significance was identified for female genital cancers $(p=0.05)$, but was interpreted as probably spurious. The previously identified correlation for multiple myeloma persisted $(\mathrm{p}=0.002)$.

Kev Words: RADIOACTIVITY - onsite (Hanford) workers, potential health effects, risk assessment, statistical analysis

\section{G-21}

Gilmore,R. D. 1983. "Emergency Preparedness for Nonradiological Incidents at Hanford." In Fourth Departmentof Energy Emereency Preparedness Meeting pp. 519-525. PNL-SA-11445,Pacific NorthwestLaboratory, Richland, Washington.

Abstract: Contractors at Hanford are committed to a common mission for the safe, secure, environmentally sound, and cost-effective work under assigned energy and defense programs. Onsite service groups help by providing many essential emergency, security, and technical skills. These groups support all contractors at Hanford to avoid duplication of resources. Because Hanford's contractors use common facilities, there are special coordination and communication requirements. The Uniform Dose Assessment Center provides coordination of resources and consultation for dealing with nonradiological emergencies.

Key Words: HANFORD SITE - nonradiological emergency response, response coordination, Uniform Dose Assessment Center

\section{G-22}

Glantz,C. S., and M. M. Islam. 1988. The Data Collection Component of the Hanford Meteorological Monitoring:Program. PNL-6684, Pacific Northwest Laboratory, Richland, Washington. 116 p., App. A through $\mathrm{C}$.
Contents: Meteorological monitoring is intensive at the DOE's Hanford Site. The program involves the measurement, observation, and storage of various meteorological data; continuous monitoring of regional weather conditions by staff meteorologists; and around-the-clockforecasting of site weather conditions. This report documents data collection under the program. Each meteorological monitoring site is discussed in detail, including the HMS, 200-ft instrumented tower sites, 40 -ft instrumented tower sites, 30-ft instrumented tower sites with AC power, 30-ft instrumented tower sites with battery power, and sites with special characteristics. Methods for processing and communicating data to the HMS are also discussed. Procedures followed to maintain and calibrate these instruments are presented.

Kev Words: AIR AND ATMOSPHERE- data collection/processing, equipment/facilities, Hanford Meteorological Station, monitoring programs, monitoring sites

\section{G-23}

Glantz, C. S., and J. V. Ramsdell. 1986. Preliminary Examination of the Imnacts of Repository Site Characterization Activities and Facilitv Construction and Operation Activities on Hanford Air Ouality. PNL5687, Pacific Northwest Laboratory, Richland, Washington. 31 p., App. A and B.

Abstract: Air quality impacts that would result from development of a high-level nuclear waste repository on the Hanford Site are estimated with two simple atmosphericdispersion models, HANCI-II and CHISHORT. Results indicate that pollutant concentrations would not exceed ambient air quality standards at any point outside the Hanford boundary or at any publicly accessible location onsite. The increase in pollutant levels in nearby communities from development activities would be minimal. HANCHI and CHISORT are documented in the appendices of the document. Further study of the repository's impact on air quality is needed when more detailed project plans and work schedules are available.

Kev Words: AIR AND ATMOSPHERE- air quality, CHISHORT model, HANCI model, impact assessment 
Graham, D. L. 1983. Stable Isotope composition of Precipitation from the Rattlesnake Hills Area of South-Central Washington State. RHO-BW-ST44 $\mathrm{P}$, Rockwell Hanford Operations, Richland, Washington. $25 \mathrm{p}$.

Abstract: This work supported hydrologic studies in Columbia River basalts beneath the Hanford Site. From December 1981 through May 1982, 62 samples were collected during two snow and seven rain events, and analyzed for delta oxygen-18 and deuterium. Parts of the data fell below the established global meteoric waterline, apparently because of kinetic effects from wind-driven evaporation and the "amount effect." A similar isotopic shift appeared in shallow ground-water data because of multistage evaporation. The first stage occurred during precipitation and the second before or during infiltration. The shallow basaltic ground waters were most similar isotopically to local precipitationfalling during winter months. The similarity suggested that precipitation recharging the shallow ground-water system in the past was similar to precipitation now falling during winter in the RattlesnakeHills area.

Kev Words: GEOLOGY AND HYDROLOGY basalt bedrock, ground-waterrecharge, precipitation effects, surface recharge

\section{G-25}

Graham, M. J. 1981. "The RadionuclideGroundWater Monitoring Program for the Separations Area, Hanford Site, Washington State." Ground Water Monit. Rev. 1:52-56.

Contents: Rockwell is prime contractor to the DOE for waste management at Hanford. The Separations Area (200 Areas), near the center of the Hanford Site, contains major radioactive waste storage and liquid waste disposal facilities. PNL runs the ground-water monitoring program for the entire Hanford Site. This article reviews the current hydrogeology and radionuclide ground-water monitoring program, relating this program to historical use of the site, and describes existing facilities, geology, climate, and specifics of the program.
Kev Words: EFFLUENTS AND WASTES - ground water, Hanford Site, monitoring program, radioactive waste management

\section{G-26}

Graham, M. J., and W. R. Brown. 1981. Results of the Senarations Area Ground-Water Monitoring Network for 1980. RHO-LD-165, Informal Report, Rockwell Hanford Operations, Richland, Washington. 34 p., App. A through D.

Abstract: The Separations Area network has 107 wells to monitor water quality, 10 more than in 1979. Water levels in the unconfined and confined aquifers are also monitored. Maps on water-table and depthto-water table are produced semiannually for the 200 East and 200 West areas. A map on the water-table over the Hanford Site is produced annually. Water samples are collected at intervals (monthly to semiannually)and analyzed for total alpha, total beta, ${ }^{60} \mathrm{Co},{ }^{106} \mathrm{Ru},{ }^{137} \mathrm{Cs},{ }^{90} \mathrm{Sr}$, tritium, uranium, and nitrate.

Results for 1980 are similar to 1979 results. The guideline of $3,000 \mathrm{pCi} / \mathrm{mL}$ for tritium was exceeded in only one sample, from the well monitoring the active 216-S-25 crib. Except for tritium, all contamination above $10 \%$ of guidelines was caused by past disposal to sites no longer active. The only samples with contamination in excess of guidelines were from the 299-W22-1 well, which monitors the inactive 216S-1 and 216-S-2 cribs, but the contamination zone is localized. Contamination in ground water moving from the Separations Area is below guidelines.

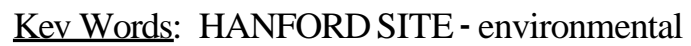
monitoring, ground water, monitoring wells, radioactivity, regulatory compliance, 200 Areas

\section{G-27}

Graham, M. J., M. D. Hall, S. R. Strait, and W. R. Brown. 1981. Hydrology of the Separations Area. RHO-ST-42, Rockwell Hanford Operations, Richland, Washington. Irregular pages, App. A through D.

Abstract: The unconfined aquifer beneath the Separations Area is contained in the Ringold and Hanford 
formations. Hydraulic conductivity ranges from 3 to $3,000 \mathrm{~m} /$ day ( 9 to $10,000 \mathrm{ft} /$ day), and storage coefficients range from 0.0002 to 0.07 . The higher values associate with the Hanford Formation, lower values with the Ringold Formation. A textural unit near the bottom of the aquifer acts as a separate confined aquifer. Anisotrophy values range from 13 to 16 .

Artificial recharge from liquid waste disposal is estimated to be 10 times the natural recharge to the Separations Area. It has created two large groundwater mounds under $\mathrm{U}$ and $\mathrm{B}$ ponds, and induced two artificial flow systems. Horizontal gradients resulting from the mounds are up to $10 \mathrm{~m} / \mathrm{km}$ (50 ft/mile), while downward vertical gradients are as high as $10 \%$. Estimates of travel time from 200 West Area to the Columbia River range from 80 to 120 years. The prevalent chemical feature of the aquifer is calcium bicarbonate. Sodium bicarbonateand calcium sulfate waters are also present. Contamination plumes indicate a flow to the east and southeast.

\section{Kev Words: GEOLOGY AND HYDROLOGY -}

flow rates, ground water, ground-water mounds, hydraulic conductivity, travel times, unconfined aquifer, water quality, 200 Areas

\section{G-28}

Graham, M. J., G. V. Last, and K. R. Fecht. 1984. An Assessment of Aquifer Intercommunication in the B Pond-Gable Mountain Pond Area of the Hanford Site. RHO-RE-ST-12 P, Rockwell Hanford Operations, Richland, Washington. 98 p., App. A and B.

Abstract: Aquifer communication refers to the migration of ground water from the unconfined aquifer to the underlying confined aquifer through areas where rock barriers do not block flow. Historical discharges of effluent from chemical process plants to surface facilities have raised hydraulic head values in the unconfined aquifer to exceed those in the Rattlesnake Ridge (RR) aquifer, the upper confined aquifer. Thus, a driving force has been created for carrying contamination in the unconfined aquifer to the RR aquifer. This report describes hydrogeologic conditions related to aquifer intercommunication near B pond and Gable Mountain pond, encompassing the 200 East Area where subsurface liquid-waste disposal facilities are located. An increase in waste disposal activities is planned for this area.
Erosional "windows" through the confining bed (Elephant Mt. basalt) provide direct interconnections between the unconfined and RR aquifers. Two completely eroded areas were identified in the confining bed, and two other eroded areas were inferred from geological and hydrological evidence. Downward gradients from the unconfined aquifer to the RR aquifer were identified near Gable Mt. Pond and B Pond, but they do not now extend to known or suspected areas of erosion in the confining bed.

From ground-water chemical data, an area of aquifer communication was identified south and east of Gable Mt. Pond and extending to the 200 East Area. The connection was probably made in the late 1960 's and early 1970's, when the water table was higher. As a result, low levels of tritium and ${ }^{129} \mathrm{I}$ (below drinking water standards) were identified in the RR aquifer. Contamination of the RR aquifer also resulted from the migration of wastes by density flow down an existing borehole, which had been open to the two aquifers for several years. Contamination in the RR aquifer will eventually discharge back to the unconfined aquifer near West Lake. Surveillance of the RR aquifer will continue.

Kev Words: GEOLOGY AND HYDROLOGY aquifer communication, confined aquifer, contamination areas, subsurface characteristics, Rattlesnake Ridge aquifer, unconfined aquifer, 200 Areas

\section{G-29}

Gray, R. H. 1980. "Fish Behavior: Biological and Engineering Considerations." North. Engin. 12:4-12.

Contents: Several studies during the 1970's with fish species common in the Hanford Reach were reviewed. The work was varied, but included the responses of adult and juvenile salmonids to warmed water, gas supersaturated water, and chlorinated effluents. The way that fish behave can modify the effects of changed water quality, thus influencing assessment of environmentalimpacts from power generation.

Kev Words: AQUATIC ECOLOGY - environmental assessment (general), fish behavior, Hanford Reach, power generation, salmonids 
Gray, R. H. 1987. "Behavior: Studies of Fish Migration and Their Application to Environmental Assessment." In Environmental Risk: Recognition. Assessment. and Management, p. 137. (Abstract) Eighth Annual Meeting, Society of Environmental Toxicology and Chemistry, Pensacola, Florida.

Abstract Fish migration is essential to population survival. Migratory species generally travel the same route and return to specific locations at predictable times. Man-induced stressors may impede migratory routes and, thus, alter migratory behavior. Examples include dams, intake structures, and discharge systems. Various techniques have been used to study fish migration, including visual observationsand counting, netting and trapping, tagging and biotelemetry, sonic or echo location, and laboratory behavioral chambers. Examples of laboratory and field studies designed to evaluate the influence of water quality changes on fish movement and migration are reviewed, and their association with environmental assessments is discussed.

Kev Words: AQUATIC ECOLOGY - environmental assessment (general), fish behavior, fish migration

\section{G-31}

Gray, R. H. 1988. "Energy Production: Applied Environmental Evaluation and Assessment." Int. J. Environ. Stud. 32:269-284.

Abstract: Solutions to complex environmental issues require a multidisciplinary approach. Historically, such problems were studied after they were identified. For example, the intake of a power plant (at PNL) was retrofit to minimize losses of fish from the Columbia River. Currently, $\mathbf{9 3 \%}$ of the young salmon impinged on the screens survive. More recently, studies attempt to identify potential environmental problems before they appear and develop ways to avoid them. Combined toxicological, chemical, and engineering evaluations have identified acceptable options to minimize toxicity of coal liquefaction products. Once an industry or activity is in place, monitoring and assessment as conducted at the DOE's Hanford Site must continue to ensure protection of the environmentand human health.
Radiation doses from Hanford have been well below applicable standards, and are much less than doses received from natural sources or radiation from medical diagnoses.

Key Words: HANFORD SITE - environmental monitoring, Hanford Reach, hazardous materials, overview, radioactivematerials

\section{G-32}

Gray, R. H. 1988. "Environmental Monitoring at the U.S. Department of Energy's Hanford Site, Washington." In Abstracts. DOE Model Conference, p. 49. Oak Ridge National Laboratory, Oak Ridge, Tennessee.

Abstract: Environmental monitoring has been conducted at the Hanford Site for over $\mathbf{4 0}$ years. Monitoring objectives are to detect and assess potential impacts of site operations on air, surface and ground water, foodstuffs, fish, wildlife, soil, and vegetation. Data from monitoring efforts are used to calculate the radiologicalimpact to humans working onsite or residing in nearby communities, and to assess the affects on key fish and wildlife populations. In 1986, average concentrations of airborne radionuclides at the Site perimeter were below applicable DOE and EPA guidelines. Concentrations of radionuclides were below drinking water standards at municipal river water intakes. Radionuclidesin foodstuffs were similar in control and irrigated areas. Low levels of ${ }^{90} \mathrm{Sr}$ and ${ }^{137} \mathrm{Cs}$, and of fallout radionuclides, occurred in onsite wildlife and in soils and vegetation from onsite and offsite. Low-levels of radionuclidesfrom passage of the Chemobyl plume occurred in air, surface water, milk, and vegetation. The calculated effective dose potential received by a maximally exposed individual during 1986 was about $0.1 \mathrm{mrem}$. Measured exposure to penetrating radiation and calculated radiation doses to the public for $\mathbf{1 9 8 6}$ were well below applicable regulatory standards.

Kev Words: HANFORD SITE - environmental monitoring, monitoring program, overview, radioactivity 
Gray, R. H. 1988. "Fisheries Science: One Component of the MultidisciplinaryEnvironmental Monitoring Program at Hanford, Washington." In Fisheries Management: A Transdisciplinary Science, Abstracts of 118th Annual Meeting, pp. 95. American Fisheries Society, Bethesda, Maryland.

Abstract: Fisheries is one concern of the environmental monitoring program at the Hanford Site, southeastern Washington. Each year, radioactivity is measured in fish, redds of chinook salmon are counted, and samples of air, surfaceand ground water, foodstuffs, wildlife, soil, and vegetation are analyzed. In 1986, average amounts of radionuclides in air samples at the Hanford periphery and in water at the municipal intake were within applicable guidelines. No other samples indicated significant offsite movement of radioactivity. Further, measured exposure to penetrating radiation and calculated radiation doses to the public were below applicable regulatory limits.

Kev Words: HANFORD SITE - environmental monitoring,Hanford Reach, monitoring program, radioactivity

\section{G-34}

Gray, R.H. 1988. "Overview of a Comprehensive EnvironmentalMonitoring and SurveillanceProgram: The Role of Fish and Wildlife." In Western Proceedings, 67th Annual Conference Western Association of Fish and Wildlife Agencies. (Abstract) American Fisheries Society, Bethesda, Maryland.

Abstract: Concern about potential releases from nuclear and non-nuclearactivities on the Hanford Site has evolved over 4 decades into a comprehensive environmental sampling and surveillance program. Monitoring includes field sampling, and chemical and physical analyses of air, surfaceand ground water, fish and wildlife, soil, foodstuffs, and vegetation. In addition to monitoring radioactivity in fish and wildlife, populations of key species are assessed, usually during the breeding season. Chinook salmon spawning and bald eagle nesting has increased in recent years. An elk herd, established in 1972, is also increasing. Canada geese, great blue herons, mule deer, coyotes, and other animals are common. Measured exposures to penetrating radiation and calculated radiation doses to the public are well below applicable regulatory standards.

Key Words: HANFORD SITE - environmental monitoring,Hanford Reach, monitoring program, overview, radioactivity, wildlife

\section{G-35}

Gray, R. H. 1988. "Water Quality: A Component of Environmental Monitoring at Hanford, Washington." In Abstracts, 24th Annual American Water Resources Association Conference. Milwaukee. Wisconsin. American Water Resources Association, Bethesda, Maryland.

Abstract: Water quality is a key issue in environmental monitoring and surveillance at the DOE's Hanford Site. In addition to radioactivity and chemicals in surface and ground water, air, foodstuffs, wildlife, soil, and natural vegetation are monitored. Data are used to evaluated the environmental affect of onsite operations, and to calculate radiological exposure of humans working onsite or living nearby. In 1986, none of the average concentrations of radionuclides measured in air at the Hanford Site perimeter exceeded applicable guidelines. Radionuclidesat a municipal water intake on the Columbia River were below concentration limits for drinking water. Chinook salmon occur in the Hanford Reach, and bald eagles, Canada goose, great blue heron, elk, mule deer, coyotes occur onsite. Concentrations of radionuclidesin irrigated and nonirrigated foodstuffs were similar. Low levels of ${ }^{90} \mathrm{Sr}$ and ${ }^{137} \mathrm{Cs}$ were found in some onsite wildlife, as were radionuclidesfrom worldwidefallout. Low levels of radionuclides occurred in soil and vegetation from onsite and offsite. Measured exposure to penetrating radiation and calculated radiation doses to the public were below applicable regulatory guidelines.

Kev Words: HANFORD SITE - environmental monitoring,overview, radioactivity, wildlife

\section{G-36}

Gray, R. H., T. L. Page, D. A. Neitzel, and D. D. Dauble. 1986. "Assessing Population Effects from Entrainment of Fish at a Large Volume Water Intake." Environ. Sci. Health A21:191-209. 
Abstract: A method is described to quantify population effects from entrainment of juvenile chinook salmon at the intake of the Hanford Generating Project on the Hanford Reach. The program sampled wild fish in the river, entrained fish (released marked and natural unmarked) within the intake, and estimated: 1) the number of fish entrained,2) the size of the natural population, and 3) percent of natural population affected.

Kev Words: AQUATICECOLOGY - effect of entrainment,HGP, juvenile chinook salmon, effect of powergeneration

\section{G-37}

Greager,E. M. 1980. Radiological Surveillance Report for the 100-N Area Environment- 1980. UNI-1581, UNC Nuclear Industries, Richland, Washington. 37 p., App. A.

Abstract: Samples of air, ground water, vegetation, soil, and sediment from the $100 \mathrm{~N}$ Area were analyzed for radioactivity. Radiation was measured directly around the $1301 \mathrm{~N}$ facility and along the river shoreline. Special samples were taken to monitor biotransport. Facilities in the $100 \mathrm{~N}$ Area were in compliance with applicable regulations during FY 1980, and there were no significant environmental impacts from reactor operations.

Kev Words: HANFORD SITE - environmental monitoring, N Reactor, radioactivity, $100 \mathrm{~N}$ shoreline, deactivated reactors, 100 Areas

\section{G-38}

Greager, E. M. 1981. UNCEnvironmental Surveillance Report for the 100 Areas - FY 1981. UNI1849, UNC Nuclear Industries, Richland, Washington. 37 p., App. A.

Abstract: Samples of air, ground water, vegetation, soil, and sediment from the $100 \mathrm{~N}$ Area were analyzed for radioactivity. Radiation was measured directly around the $1301 \mathrm{~N}$ facility and along the river shoreline. Soil and vegetation samples were analyzed from retired 100 Areas. Special samples to monitor biotransport were included. Facilities in the $100 \mathrm{~N}$ Area were in compliance with applicable regulations during FY 1981, and there were no significant environmental impacts from past or present reactoroperations.

Kev Words: HANFORD SITE - environmental monitoring, N Reactor, radioactivity, $100 \mathrm{~N}$ shoreline, deactivated reactors, 100 Areas

\section{G-39}

Greager,E. M. 1982. UNC Environmental Surveillance Report for the 100 Areas - FY 1982. UNI2226, UNC Nuclear Industries, Richland, Washington. 37 p., App. A.

Abstract: Samples of air, ground water, vegetation, soil, and sediment from the $100 \mathrm{~N}$ Area were analyzed for radioactivity. Radiation was measured directly around the $1301 \mathrm{~N}$ facility and along the river shoreline. Soil and vegetation samples from the retired 100 Areas were analyzed. Ground-water samples were analyzed from monitoring wells in the $100 \mathrm{~K}$ Area. Special samples to monitor biotransport were included. Facilities in the 100 Areas were in compliance with applicableregulations during FY 1982 , and there were no significantenvironmental impacts from past or present operations.

Key Words: HANFORD SITE - environmental monitoring, N Reactor, radioactivity, $100 \mathrm{~N}$ shoreline, deactivated reactors, 100 Areas

\section{G-40}

Greager, E. H. 1983. UNC Environmental Surveillance Report for the 100 Areas - FY 1985 UNI2640, UNC Nuclear Industries, Richland, Washington. 38 p., App. A.

Abstract: Samples of air, ground water, vegetation, soil, and sediment from the $100 \mathrm{~N}$ Area were analyzed, and radiation was directly measured around the $1301 \mathrm{~N}$ facility and along the river shoreline in FY 1983. Samples of soil and vegetation were analyzed from retired 100 Areas. Ground water was analyzed from wells in the $100 \mathrm{~K}$ Area. Special samples were used to monitor biotransport of radionuclides. Facilities in the 100 Areas were in compliance with applicable regulations in 1983, and there were no significant environmental impacts from past or present reactoroperations. 
Kev Words: HANFORD SITE - environmental monitoring, NReactor, radioactivity, $100 \mathrm{~N}$ shoreline, deactivated reactors, 100 Areas

\section{G-41}

Greager,E. H. 1984. UNCEnvironmental Surveillance Report for the 100 Areas - FY 1983. UNI3069, UNC Nuclear Industries, Richland, Washington. 37 p., App. A.

Abstract: Samples of air, ground water, vegetation, soil, and sediment from the $100 \mathrm{~N}$ Area were analyzed, and radiation was directly measured around the $1301 \mathrm{~N}$ facility and along the river shoreline in FY 1984. Samples of soil and vegetation were analyzed from retired 100 Areas. Ground water was analyzed from wells in the $100 \mathrm{~K}$ Area. Special samples were used to monitor biotransport of radionuclides. Facilities in the 100 Areas were in compliance with applicable regulations in 1984, and there were no significant environmental impacts from past or present reactor operations.

Kev Words: HANFORD SITE - environmental monitoring, N Reactor, radioactivity, $100 \mathrm{~N}$ shoreline, deactivated reactors, 100 Areas

\section{G-42}

Gurley, R. N., K. M. LaRue, R. J. Thompson, K. R. Shah, J. E. Minor, and D. H. Siemens. 1986. "Design Aspects of the Hanford Waste Vitrification Plant." In Waste Management '86, Proceedings of the Svmposium on Waste Management. Vol. 2 HighLevel Waste, ed. R. G. Post, pp. 455-460. University of Arizona Press, Tucson, Arizona.

Abstract: Rockwell has the lead responsibility for development, design, construction, and operation of the Hanford Waste VitrificationPlant. The facility will vitrify existing and future liquid high-level and TRU wastes produced by defense activities on the Hanford Site. PNL is responsible for providing technology for the waste form and the vitrification system to be used in the HWVP. At present, the HWVP is proceeding with reference conceptual design. Definitive design is planned to start in FY 1988.
Kev Words: EFFLUENTS AND WASTES -highlevel waste, waste vitrification plant, in situ vitrification, transuranic waste, waste treatment

\section{G-43}

Gutknecht, P. J., W. A. Rice, C. R. Cole, and M. D. Freshley. 1980. Pasco Basin Hvdrometeorological Study. PNL-3855, prepared for Rockwell Hanford Operations (RHO-BWI-C-98) by Pacific Northwest Laboratory, Richland, Washington. 93 p., App. A through $\mathrm{F}$.

Contents: Precipitation and evapotranspiration distributions over the Pasco Basin are detailed for use in ground-water recharge calculations. This work supports initial efforts of the DOE to examine the feasibility of a deep geologic repository for radioactive wastes in the Columbia River Basalt group beneath Hanford. Study results are shown on precipitation and evaporation distribution maps. The parameters,calculation methods, sensitivity determinations, and fitting methods used in map development are also discussed.

Kev Words: GEOLOGY AND HYDROLOGY evapotranspiration, ground water, ground-water recharge, Pasco Basin, precipitation effects, surface recharge

\section{$\mathrm{H}-1$}

Hadley, R. T. 1985. RL Nonradiological Hazardous Materials Emergency Plan. HEHF-53, Hanford Environmental Health Foundation, Richland, Washington.

Contents: This report contains emergency response plans to protect onsite personnel, public health and safety, and the environment should an accident occur that involves hazardous materials (nonradioactive)on the Hanford Site. Each contractor is responsible for developing and implementing emergency response plans in accordance with DOE Order 5500. This report outlines areas that need to be addressed by the contractors and provides appropriate guidance.

Key Words: HANFORD SITE - contractor responsibilities, emergency response plan (ERP), emergency preparedness, nonradiologicalresponse 
Haynes, J. M., and R. H. Gray. 1981. "Diel and Seasonal Movements of White Sturgeon (Accipenser transmontanus) in the Mid-Columbia River." Fish. Bull. 79:367-370.

Abstract: Radiotransmitterswere attached to adult white sturgeon in the Hanford Reach. Fish movement and selected temperatures were monitored. Temperature changes of $2^{\prime}$ to $4^{\circ} \mathrm{C}$ were experienced by fish daily, but diel movements were probably influenced most by light. Sturgeon moved to cool, deeper areas before sunrise and to warm, shallow areas after sunset. Movement declined in fall when temperatures dropped below $13^{\circ} \mathrm{C}$.

Kev Words: AQUATICECOLOGY - fish movement, effect of light, effect of temperature, Hanford Reach, white sturgeon

\section{$\mathrm{H}-3$}

Hayward, W. M., and R. J. Jensen. 1980. Environmental Aspects of Lone-Term Management Alternatives for High-Level Defense Waste at the Hanford Site. RHO-LD-140, Rockwell Hanford Operations, Richland, Washington. 220 p., App. A and B.

Contents: Alternatives for long-term disposal of HLW on the Hanford Site were again evaluated to form a basis for comparing environmental aspects of implementing technical options. Four general alternatives, each providing for both in-tank and encapsulated wastes, were selected for further consideration: 1) near-term geologic disposal of stored waste, 2) defer geologic disposal of in-tank waste, 3) in situ disposal of in-tank waste, and 4) continue present action for stored waste.

\section{Kev Words: EFFLUENTS AND WASTES -} geologic disposal, high-level waste, remedial assessment, radioactive waste management

\section{$\mathrm{H}-4$}

Hedlund, J. D., and L. E. Rogers. 1980. "Great Basin Pocket Mice (Perognathusparvus) in the Vicinity of Radioactive Waste ManagementSites." Northwest Sci. 54:153-159.
Abstract: Population features of Great Basin pocket mice were measured near radioactive waste disposal sites at Hanford and at a nearby protected (control) site. Mice emerged from belowground turpor in March, with males appearing before females. Young-of-yearwere first abundant aboveground during June. The ratio of males to females was about $1: 1$, except during early spring months. Seasonal abundance peaks were estimated to be 47 and 42 mice/ha at disposal and control areas, respectively. Peaks in pocket mouse biomass were estimated to be 541 and $683 \mathrm{~g} / \mathrm{ha}$ at disposal and control sites, respectively. Proportions of reproductively active males and females were equal at both sites.

Kev Words: TERRESTRIALECOLOGY - effect of radioactivity, Great Basin pocket mouse, population density, reproduction, waste burial sites

\section{H-5}

Heller, P. R., G. W. Gee, and D. A. Myers. 1985. Moisture and Textural Variations in Unsaturated Soils/Sediments Near the Hanford Wye Barricade. PNL-5377, Pacific Northwest Laboratory, Richland, Washington. 25 p., App. A through D.

Abstract: During November and December 1983, soil samples were collected from five wells near the Wye barricade for hydrological characterizationof sedimentsin the partially saturated(vadose) zone. Sediment profiles at this location were heterogeneous but, in general, the soils were coarse-textured and drained rapidly. Soil profiles were wet to a depth of over $25 \mathrm{~m}$, suggesting that drainage occurred at this site. Rates of drainage were estimated at between 0.5 and $5.0 \mathrm{~cm} / \mathrm{yr}$. Times for water to move through the unsaturated zone down to the water table would range from less than 100 years to over 800 years for annual water influx rates of 5.0 to $0.5 \mathrm{~cm} / \mathrm{yr}$, respectively. The determined soil properties will be useful in modeling the movement of water and chemicals (e.g. radionuclides) to the ground water at this site.

Kev Words: GEOLOGY AND HYDROLOGY - soil characteristics, soil drainage, soil moisture, unsaturated (vadose) zone, Wye barricade 
Higby, D. P., and J. T. Denovan. 1982. Pacific Northwest Laboratory Plan to Maintain Radiation Exnosure As Low As Reasonablv Achievable (ALARA). PNL-4560, Pacific NorthwestLaboratory, Richland, Washington. 25 p.

Abstract: The radiation safety program at PNL is based on the philosophy that exposure to radiation must be maintained "as low as reasonably achievable (ALARA)." PNL is committed to the concept that personal and environmental radiation exposures shall be kept to the lowest levels commensurate with sound economics and operating practices. This document describes operating practices and the administrative policies supporting them, safety goals and objectives, training and education, and quality assurance. The radiation safety program is updated, revised, and improved to keep exposure to ionicing radiation ALARA among PNL staff.

Kev Words: HANFORD SITE - ALARA, radiation safety program, safety training

\section{H-7}

Horst, T. W., and J. C. Doran. 1982. Simple Nocturnal Slone Flow Data from the Rattlesnake Mountain Site. PNL-4406, Pacific Northwest Laboratory, Richland, Washington. 98 p.

Abstract: Vertical profiles of wind and temperature of nocturnal slope flows were measured at a site that was uniform in cross-slopedirection. The upper part of the slope approximated a simple, tilted plane. The measurements were taken from three towers at different distances from the ridge crest, each of which extended through the local depth of the katabatic flow. This report lists the tower wind and temperature data from the four best cases of slope flow observed in 1980 and 1981. It gives ambient wind and temperature profiles to a height of $300 \mathrm{~m}$ from a tethersondeflown at the experimental site, and surface winds from a network of stations around the site.

Kev Words: AIR AND ATMOSPHERE - Rattlesnake Mt., nocturnal slope flow, temperature, wind
Howe, D. B., R. C. Aldrich, R. S. Shay, and L. J. Voight. 1987. Rockwell Hanford Operations Effluents and Solid Waste Burials During Calender Year 1986. RHO-SH-SR-86-1P, Rockwell Hanford Operations, Richland, Washington. 170 p., App. A through $\mathrm{E}$.

Abstract: All radioactive liquid and gaseous discharges were in compliance with DOE Order 5480.1B, as amended, during 1986. Two gaseous streams exceeded Rockwell administrativecontrol values (ACV), which are more restrictive. Annual averageconcentrations were exceeded for ${ }^{106} \mathrm{Ru}$ by the PUREX plant ammonium scrubber stack (1.13 times the ACV) and for ${ }^{129} \mathrm{I}$ by the 241-AW tank farm stack (1.82 times the ACV). Two liquid streams exceeded ACVs. Annual average concentrations were exceeded for ${ }^{239240} \mathrm{Pu}$ by the PUREX process condensate stream (1.87 times the ACV), and for ${ }^{106} \mathrm{Ru}$ by the PUREX ammonia scrubber stream. No opacity violations were exceeded by the 200 Area power plants, and seven deviations from opacity guidelines (local Air Pollution Control Authority) were reported. Emissions of nitrogen oxides from PUREX and the $\mathrm{UO}_{3}$ plants were below annual limits.

In 1986, after installation of the fourth filter at PUREX in October 1985, the annual average total alpha concentration at the main stack decreased by $99 \%$. The nitrate content in liquid effluents decreased by $99 \%$. The volume of industrial waste burials was twice that of 1985, primarily because more offsite waste was received. Permanent burial of nonradioactive dangerous or hazardous waste chemicals was discontinued, and $549,000 \mathrm{~kg}$ was sent offsite for recycle or disposal.

Key Words: EFFLUENTS AND WASTES - environmental monitoring, nonradioactivereleases, PUREX Plant, radioactivity, solid waste, waste disposal, $\mathrm{UO}_{3}$ Plant, 200 Areas

H-9

Huizenga, D. G., W. T. Farris, R. L. Treat, and A. H. McMakin. 1986. "Sensitivity Analysis of the LongTerm Performanceof the Grout System for the 
Disposal of ALow-Level Radioactive Waste Stream at Hanford." In Waste Management 1986, Vol. 3, ed. R. E. Post, pp. 165-171. University of Arizona Press, Tucson, Arizona.

Abstract: A transportablegrout facility is planned at the Hanford Site. It will combine grout-forming material with radioactiveliquid LLW to produce solidified grout monoliths for near-surfacedisposal. PNL is conducting studies to verify that the process is workable and that the grout form will provide longterm protection. Performance of the grout facility over the years depends on factors that affect release and transport of radionuclides. Several scenarios were examined in a "sensitivity analysis," based on conditions that might affect the grout system. Analysis showed that the 50150 grout disposal system adequately protects the health and safety of the public. Consumption of ground water postulated to contain released radionuclides results in a radiation dose of at least 1000 times below EPA limits. All onsite radiation doses that result from postulated intrusion into the site, with the reference 5-m depth of overburden in place, would result in doses well below the limits in DOE Order 5480.1A.

Key Words: EFFLUENTS AND WASTES - environmental assessment,low-level waste, grout treatment facility, radioactive waste management, remedial actions, waste treatment

\section{H-10}

Huston, J. R., and P. J. Blumer. 1980. Environmental Surveillanceat Hanford for CY 1979. PNL3283, Pacific Northwest Laboratory, Richland, Washington. 46 p., App. A through E.

Contents: Data collected in 1979 by PNL's Environmental Monitoring Program are reviewed. Samples taken on and off the Hanford Site provide data to assess amounts of radioactivity and chemicals from operational and natural sources. Results are given under: Atmospheric Monitoring, Columbia River Monitoring, Foodstuffs, Wildlife, Soil and Vegetation, and External Radiation. In addition, Radiological Impact of Hanford Operations from current effluents and past Hanford operations are discussed. Support data are in Appendices.
In general, offsite levels of radionuclides attributable to Hanford operations during 1979 were indistinguishable from background levels. Elevated, but still insignificant,doses attributed to a few long-lived radionuclides, principally ${ }^{60} \mathrm{Co},{ }^{137} \mathrm{Cs}$, and ${ }^{154} \mathrm{Eu}$ from past reactor discharges remained on islands and shorelines of the Columbia River. Releases of waste water at Hanford were well within NPDES permit limits.

The maximum annual whole-body dose to an individual from 1979 effluents was estimated to be less than $0.1 \mathrm{mrem}$ (compared to a $500 \mathrm{mrem} / \mathrm{yr}$ standard). The annual dose to a single organ from all pathways was less than 0.5 mrem to the thyroid (compared to a $1500 \mathrm{mrem} / \mathrm{yr}$ standard for organs other than gonads and bone marrow). The estimated annual whole-body dose to the population within an 80-km (50-mile) radius of Hanford was about 1.3 person-rem, compared to 25,000 person-rem received annually from natural background radiation.

Kev Words: HANFORD SITE - effluents and emissions, environmental monitoring, public dose estimates, public risk, radioactivity

\section{I-1}

Isaacson, R. E., and K. A. Gasper. 1981. A Scientific Basis for Establishing Dry Well Monitoring Frequencies. RHO-ST-34, Rockwell Hanford Operations, Richland, Washington. $41 \mathrm{p}$.

Abstract: Dry wells are used to detect radioactivity from a leaking, underground storage tank containing high-levelradioactive waste. The frequency of monitoring a dry well depends on the response characteristics of the radiation-detectionsystem used to examine the dry well for encroaching radioactivity. The Dry Well Radioactive ResponseEquation (DWRRE) was developed. The DWRRE is derived from 1) variation in dose rate (roentgen/hr) as a function of source strength; 2 ) variations in dose attenuation by the soil as the radioactive waste front approaches a dry well; 3 ) response of the radiation detector (counts per sec) as dose rate changes;4) distance of the dry well from tank leak source; 5) leak rate; 6) geometry of soil wetted by leaking waste; and 7) hydrologic properties of the soil. These variables are used with the current status of tank contents and 
available liquid-level-monitoringsystem information to generate appropriate monitoring schedules.

Kev Words: EFFLUENTS AND WASTES - Dry Well Radioactive Response Equation, high-level waste, radioactive waste storage, tank surveillance, waste storage tanks, 200 Areas while time spent active and feeding decreased.

Jacques, I. D. 1986. UNCEnvironmental Surveillance Report for the 100 Areas - FY 1985. UNI3760, UNC Nuclear Industries, Richland, Washington. 58 p., App. A and B.

Abstract: UNC's surveillance program monitors several environmental features in the 100 Areas to evaluate the impact of the $\mathrm{N}$ Reactor, the shutdown production reactors, and waste burial grounds in retired areas. Highlights for FY 1985 were: 1) no significant release or biotransport of radionuclides occurred from the $100 \mathrm{~N}$ Area, 2) vegetation near the $\mathrm{N}$ Springs (shoreline seep) contained ${ }^{90} \mathrm{Sr}$ above background levels, 3 ) radionuclides released to the 1301-N LWDF (no longer receiving effluents) occurred in surface soil, vegetation, and deer mice adjacent to the site, 4) sediments from the 1301-N trench and the 1315-N LWDF crib had decaying activation and fission products from the NReactor (discharges to 1301-N LWDF stopped in September, 1985; plans are under way to isolate the facility), 5) no significant release or biotransport of radionuclides occurred from retired 100 Area facilities, 6) some radionuclides, primarily ${ }^{90} \mathrm{Sr}$ and ${ }^{137} \mathrm{Cs}$, were assimilated by vegetation at selected burial grounds in 100 Areas, and 7) air samples near the $183-\mathrm{H}$ facility and within basin \#1 during cleanup indicated no offsite spread.

Key Words: HANFORD SITE - environmental monitoring, deactivated reactors, $\mathrm{N}$ Reactor, radioactivity, 100 N shoreline, 100 Areas, 1301-N trench, 1301-NLWDF
Jacques, I. D. 1987. UNCEnvironmental Surveillance Report for the 100 Areas - FY 1986. UNI4065, UNC Nuclear Indusmes, Richland, Washington. 57 p., App. A and B.

Abstract: UNC's surveillance program monitors several environmental features in the 100 Areas to evaluate the impact of the N Reactor. the shutdown production reactors, and waste burial grounds in retired areas. Highlights for FY 1986 were: 1) no significantrelease or biotransport of radionuclides occurred from the $100 \mathrm{~N}$ Area, 2) vegetation near the $\mathrm{N}$ Springs contained ${ }^{90} \mathrm{Sr}$ above background levels, 3) residual levels of radionuclides released to the closed 1301-N LWDF were in nearby surface soil and vegetation,4) sediments from the closed $1325-\mathrm{N}$ LWDF crib had decaying activation and fission products from NReactor, 5 ) radiation measured directly near the 1301-N LWDF and along the Columbia River shoreline were higher than in previous surveys from residual radionuclides and absence of shielding water, 6) an underground pipe leaked about 1,000 gallons of \#2 diesel oil to the ground near the 184-N Powerhouse, 7) no significant release or biotransport of radionuclides occurred from retired reactorfacilities, and 8) some radionuclides, primarily ${ }^{137} \mathrm{Cs}$, were assimilated by vegetation at burial grounds.

Kev Words: HANFORD SITE - environmental monitoring, deactivated reactors, N Reactor, radioactivity, shoreline, 100 Areas, 1301-N trench, 1301-N LWDF

\section{$\mathrm{J}-3$}

Jamison, J. D. 1982. "Site Description." In Standardized Inout for Hanford Environmental Imoact Statements,Part 2, pp. 9.1-9.16. PNL-3509, Pacific Northwest Laboratory, Richland, Washington. Irregular pages, App. A through E.

Contents: A description of the Hanford Site is given that can be used when evaluating the environmental impacts of new projects. The summary description (Chapter 1.0), when amplified with appropriate material, can serve as the basic site description for 
environmental impact statements that comply with the National EnvironmentalPolicy Act. Chapters are: Summary Description,Location and Physiography, Geology, Seismology, Hydrology, Meteorology, Ecology, Demography and Land Use, and Radiological Condition.

Kev Words: HANFORD SITE - generic information, NEPA characterization

J-4

Jansky, M. T. 1985. "Slurry Growth: The Characterization of a Unique Phenomenon at the Hanford Site." In Waste Management '85. Proceedings of the Symposium on Waste Management, Vol. 2 Waste Policies and Programs, Low-Level Waste, ed. R. G. Post, pp. 593-596. University of Arizona Press, Tucson, Arizona.

Abstract: Slurry growth occurs in certain storage tanks containing HLW at Hanford even if new waste is not added. Growth results from entrapment of gas within the waste slurry, which causes it to expand. Gases causing slurry growth are produced by decomposition of organic materials present in HLW (e.g., HEDTA, EDTA, GLY). Prominent gases are $\mathrm{H}_{2}, \mathrm{~N}_{2}, \mathrm{~N}_{2} \mathrm{O}, \mathrm{NO}_{\mathrm{x}}$, and $\mathrm{CO}$. More gas is generated, and at a fasterrate, as the temperatureincreases. Waste of high viscosity entraps more gas. Slurry growth in storage tanks is under control but not completely eliminated.

Kev Words: EFFLUENTS AND WASTES - highlevel wastes, radioactive sludge, slurry growth, waste storage tanks, 200 Areas

\section{$\mathrm{J}-5$}

Jaquish, R. E. 1988. Environmental Monitoring at Hanford for 1987 - Surface and Columbia River Data. PNL-6634, Pacific Northwest Laboratory, Richland, Washington. $291 \mathrm{p}$.

Contents: This report is a tabulation of data used to prepare PNL's annual environmental report summaries, titled "Environmental Monitoring at Hanford for (calender year)." Data on air, surface water, TLD samples, foodstuffs, wildlife, soil, vegetation, and nonradioactive air materials are given as they were recorded.
Kev Words: HANFORDSITE - effluents and emissions, environmental monitoring, nonradioactive releases, radioactivity

\section{J-6}

Jaquish, R. E., and L. E. Bisping. 1988. Environmental Monitoring Master Schedule JanuarvDecember 1988. PNL-6550 (EMP-MS-88), Pacific Northwest Laboratory, Richland, Washington. 52 p.

Contents: The planned schedule is given for routine collection of environmental samples during CY 1988, as undertaken by the Surface and Groundwater Environmental Monitoring Projects at PNL. The schedule may be modified during the year in response to changes in onsite operations, program requirements, the nature of observed results, and operational limitations (such as weather and mechanical failures). The program evaluates levels of radioactive and nonradioactivepollutants at Hanford, as required by DOE Orders 5480.1A and 5484.1.

Kev Words: HANFORD SITE - environmental monitoring, sampling schedule

\section{$\mathrm{J}-7$}

Jaquish, R. E., and P. J. Mitchell (eds.). 1988. Environmental Monitoring at Hanford for 1987. PNL6464, Pacific Northwest Laboratory, Richland, Washington. Irregular pages, App. A through $\boldsymbol{G}$.

Abstract: Data collected in 1987 by PNL's Environmental Monitoring Program are reviewed. Samples taken on and off the Hanford Site provide data to assess the amounts of radioactivity and chemicals from operational and natural sources. Sections are: Air, Ground Water, Surface Water, Food and Farm Products, Wildlife, Soil and Vegetation, Penetrating Radiation, and Comparison of Measured and Calculated Concentrations. In addition, Potential Radiation Dose to the Public and Quality Assurance are discussed. Support data are in Appendices.

Radioactivity in the Hanford vicinity during 1987 was well below applicable DOE and EPA standards. Radioactive materials released at Hanford were generally indistinguishable from background levels in offsite areas. The influence of the 1986 accident at the Chernobyl Nuclear Station, USSR, was no longer 
apparent. Chemical concentrations in air were below applicablestandards. Chemicals detected in ground water beneath Hanford were attributed to both onsite operations and natural background levels. Several chemicals regulated by EPA and the state of Washington occurred in excess of EPA drinking water standards. The calculated effective dose potentially received by a maximally exposed individual was about 0.05 mrem, compared to 0.09 mrem estimated for 1986. The collective effective dose to the population within $80 \mathrm{krn}$ of Hanford was 4 personrem in 1987, compared to 9 person-rem for 1986. These doses were much less than doses received from common sources of radiation, and were well below applicable DOE radiation protection standards.

Kev Words: HANFORD SITE - effluents and emissions, environmental monitoring, nonradioactive releases, public risk, radioactivity, radiation dose assessment

\section{$\mathrm{J}-8$}

Jaquish, R. E., and B. A. Napier. 1987. "A Comparison of Environmental Radionuclide Concentrations Calculated by a Mathematical Model with Measured Concentrations." PNL-SA-14720,Pacific Northwest Laboratory, Richland, Washington. 6 p.

Abstract: An extensive environmental monitoring program is conducted at the Hanford Site by PNL to quantify radioactivity and estimate the offsite population dose. Monitoring involves the collection and analysis of samples that include air particulates, water, soil, food crops, wildlife, and vegetation. Because environmental concentrations of radionuclides are so low and, in most cases, indistinguishable from previously deposited fallout radionuclides, population doses are calculated with computer dose codes. The code used to determine accumulated radiation doses from chronic ingestion of food products is PABLUM. This code estimates the transfer of radionuclides from air and irrigation water to plants, and calculates the resulting concentration in food products. In the present study, concentrations of ${ }^{90} \mathrm{Sr}$ as calculated by PABLUM were compared with measured concentrations obtained through PNL's monitoring program. Both air and water pathways showed reasonable agreement, indicating that PABLUM gives a good estimate of offsite doses.
Kev Words: RADIOACTIVITY - environmental monitoring, Hanford Site, PABLUM model, radiation dose estimates, risk assessment

\section{J-9}

Jensen, E. J. 1987. AnEvaluation of AauiferIntercommunication Between the Unconfined and Rattlesnake Ridge Aquifers on the Hanford Site. PNL-6313, Pacific Northwest Laboratory, Richland, Washington. 27 p., App. A.

Abstract: During 1986, PNL studied the part of the uppermost, regionally extensive confined aquifer, the Rattlesnake Ridge aquifer, beneath the B Pond Gable Mt. Pond area at Hanford. The purpose was to determine the extent of linkage between the unconfined aquifer (above) and the confined aquifer (below) at that location. Hydraulic head data were used to determine the effects caused by water discharged to the ground from B Pond on the water table of the unconfined aquifer and the potentiometric surface of the confined aquifer. Chemical data were used to determine the extent of chemical constituents migrating from the upper aquifer to the lower. Communication between the two aquifers had occurred but, during the study, contaminant levels in the confined Rattlesnake Ridge aquifer were below DOE Derived Concentration Guides.

Kev Words: GEOLOGY AND HYDROLOGY aquifer communication, B Pond, Gable Mt. Pond, ground water, hydraulic gradient, hydrochemical data, Rattlesnake Ridge aquifer, 200 Areas

\section{$\mathrm{J}-10$}

Jensen, E. J. 1987. Summary of Water-Level Measurements Around the 1325-Crib Durinn the Fall of 1985 and the Winter of 1986-1987. PNL-6374, Pacific Northwest Laboratory, Richland, Washington. 19 p., App. A through C.

Abstracl: Water levels were measured in 28 wells around the 1325-crib and connecting trench to monitor the rise and fall of ground water resulting from use of the facility. Water being added to the crib had a direct effect on ground-water movement at the $100 \mathrm{~N}$ Area. When the crib was used, a mound of water formed in the ground beneath it. When the crib 
was shut down, the mound flattened and dissipated outward in all directions.

Kev Words: EFFLUENTS AND WASTES - groundwater mounds, radioactive liquids, waste disposal, $1325 \mathrm{~N}$ crib, $100 \mathrm{~N}$ Area

\section{$\mathrm{J}-11$}

Johnpeer, G. D., D. Miller, and G. Goles. Assessment of Potential Volcanic Hazards Pasco Basin. Washington. RHO-BW-CR-130 P, prepared by Ertec Western, Inc., Long Beach, California, and Center for Volcanology, University of Oregon, for Rockwell Hanford Operations, Richland, Washington. 29 p.

Abstract: A volcanic hazard assessment was performed by considering: 1) the potential for renewed volcanism from three source areas (the Cascade Range, the Columbia Plateau, and the Basin and Range Providences), and 2) the potential effects of future volcanic events on a repository sited $2 \mathrm{~km}$ beneath the surface of the Pasco Basin. The potential for renewed volcanism from each source area is determined from the following estimated eruption rates $(\mathrm{ER})$ :

Cascade Range 7,000 eruptions every $10^{-6}$ yr (ER $=7 \times 10^{-3} / \mathrm{yr}$ )

Flood Basalt 1 eruption every 2 x $10^{-7}$ yr $(E R=5$ x $10^{-7} / \mathrm{yr}$ )

Basin and Range 1 eruption every $3 \times 10^{-6} \mathrm{yr}(\mathrm{ER}=$ $3.3 \times 10^{-7} / \mathrm{yr}$ )

Event networks were used to show the logical sequence of events that would follow if volcanism were to occur. Of all potential events analyzed, only a few might be hazardous to a potential repository (e.g., volcanically induced flooding, ash or lava flows, thick air-fall tephra). Still fewer were of critical concern (e.g., breach of the repository by a dike). The probabilities of occurrence of outcome events were calculated assuming the regional volcanism follows a Poisson distribution.

Kev Words: GEOLOGY AND HYDROLOGY Pasco Basin, seismology, predicted volcanic events
Jones, T. L., G. S. Campbell, and G. W. Gee. 1984. Water Balance at an Arid Site: A Model Validation Study of Bare Soil Evaooration. PNL-4896, Pacific Northwest Laboratory, Richland, Washington. $46 \mathrm{p}$.

Abstract: Transport through unsaturated soil will be the dominant pathway for movement of materials at most shallow land burial sites. Validation studies were conducted with unsaturated water flow models to simulate water balance experiments conducted at the Buried Waste Test Facility (BWTF) at Hanford. Four evaporation models were tested: two empirical models that estimated actual evaporation from potential evaporation, and two mechanistic models that described water vapor diffusion within the soil profile and between the soil and atmosphere. Accuracy of the models was evaluated by simulating water flow in one 7.6-m deep lysimeter at the BWTF from April 6, 1979, to April 30, 1980. Models that included the diffusion-type evaporation submodels performed best overall, primarily because they include water vapor flow that allows better predictions of spring and summer drying of the soil.

Kev Words: GEOLOGY AND HYDROLOGY - arid sites, computer modeling, evaporation, unsaturated flow, water balance

\section{$\mathrm{J}-13$}

Jones, T. L., and G. W. Gee. 1984. Assessment of Unsaturated Zone Transwort for Shallow Land Burial gf Radioactive Waste: Summary Report of Technology Needs. Model Verification and Measurement Effort (FY78-FY83). PNL-4747,Pacific Northwest Laboratory, Richland, Washington. 130 p., App. A and $\mathrm{B}$.

Contents: An arid site has unique features for disposal of radioactive waste, including low precipitation, deep water tables, and generally a remote location. This overview discusses interactions between climate, soil, plants, engineered barriers, and the buried wastes in terms of an arid site. It gives justification for detailed unsaturated flow and transport modeling for long-term assessment of shallow land burial sites. Water balance data, collected since FY 1978 at the Buried Waste Test 
Facility at Hanford, were used to illustrate the influence of climate variables (rainfall distribution and evaporation) on water storage and drainage $t$ an arid site. Significant deep drainage was measured under dry site conditions with no vegetation and coarse soil, and at a grass-covered site after early spring rains. The monitoring technology, water balance, and radionuclide transport at arid sites are discussed; the use of neutron probes, electrical resistance units, tensiometers, and psychrometers are explained. Measurements of water flow and transport coefficients needed to describe the movement of radionuclides in unsaturated soil are documented.

\section{Kev Words: GEOLOGY AND HYDROLOGY •} assessment, arid sites, drainage, precipitation effects, soil water potential, unsaturated flow, unsaturated (vadose) zone

\section{$\mathrm{J}-14$}

Jones, T. L., G. W. Gee, R. R. Kirkham, and D. D. Gibson. 1982. The Measurement of Water Potential in Low-Level Waste Management. PNL-4388, Pacific Northwest Laboratory, Richland, Washington. $52 \mathrm{p}$.

Contents: Measurement of soil water and its movement is important to shallow-land burial of low-level waste. This report focuses on measurement of soil water potential, and evaluates several field instruments available to monitor waste burial sites located in arid-region soils. The theoretical concept of water potential is introduced, and its relation to water content and soil water flow is discussed. Next, four major areas of soils research are presented in terms of their dependence on the water potential concept. The four major types of sensors available to measure soil water potential are discussed. Recommendations are given for use of water potential measurements in burial site characterization, site operation, site closure, and post-closure monitoring.

Key Words: GEOLOGY AND HYDROLOGY - arid sites, soil water potential, unsaturated flow, unsaturated (vadose) zone
Jones, T. L., G. W. Gee, J. L. Swanson, and R. R. Kirkham. 1983. "A Laboratory and Field Evaluation of the Mobility of Cobalt-60/EDTA." In Waste Management 1983, Vol. 2, R. G. Post (ed.), pp. 331333. University of Arizona Press, Tucson, Arizona.

Abstract: The ability of the organic complexant EDTA to keep ${ }^{60} \mathrm{Co}$ in solution depends on time and soil type. In short-term studies with soil from the Hanford Site, low sorption in batch tests and high mobility in column tests occurred. In long-term batch studies, cobalt remaining in solution decreased from $90 \%$ after 7 days to less than $10 \%$ after 500 days. In both laboratory and field column tests where low water flow rates allowed long contact time, virtually no movement of cobalt occurred even though tritium was transported (in field tests) over $4 \mathrm{~m}$. Other tests were conducted with soil from Oak Ridge and Savannah River burial grounds. The ${ }^{60} \mathrm{Co} / \mathrm{EDTA}$ complex appears to dissociate and leaves uncomplexed cobalt, which is readily sorbed. The potential for transport of cobalt by EDTA may not be as serious at burial sites as once thought.

Key Words: RADIOACTIVITY - Cobalt-60, behavior in soil, complexation, EDTA (a complexant), physicochemical properties

\section{$\mathrm{J}-16$}

Jungfleisch,F. 1988. Preliminary Evaluation of Hanford L iouid Discharges to Ground. WHC-EP. 0052, Westinghouse Hanford Company, Richland, Washington. $169 \mathrm{p}$.

Abstract: For evaluation, the 38 waste streams at Hanford were redefined as 52 unique discharges to allow for alternative process configurations of some generating facilities. This preliminary report evaluates the first 25 discharges that were completely sampled by September 30,1987. None of these 25 discharges was a dangerous waste or an extremely hazardous waste, according to dangerous waste regulations, nor were they associated with dangerous waste sources. The largest observed equivalent concentration, used to evaluate chemical toxicity, was 10 times smaller than the regulatory minimum for 
dangerous waste. The largest observed halogenated hydrocarbon level, used to evaluate chemical persistence, was 700 times smaller than the regulatory maximum limit for dangerous waste. The largest observed concentration of any specific carcinogen was 125 times smaller than the regulatory maximum for dangerous waste. The extreme observed values of $\mathrm{pH}$, used to evaluate corrosivity, were two $\mathrm{pH}$ units less acidic and two $\mathrm{pH}$ units less alkaline than the regulatory extremes of $\mathrm{pH} 2.0$ and 12.5. Indicator indexes for ignitability and reactivity show the discharges were nonignitable, nonreactive, dilute, aqueous wastes. Maximum observed concentrations of toxic metals were all less than their regulatory limits. Seven dangerous waste constituents were identified in the 25 discharges. Chloroform was released in the largest amount ( $8 \mathrm{lb}$ monthly) and was the most widely distributed (11 separate discharges).

Kev Words: EFFLUENTS AND WASTES effluents and emissions, effect of liquid effluents, Hanford Site, hazardous wastes, radioactive liquids, waste generation

\section{$\mathrm{K}-1$}

Kaiser Engineers Hanford Company. 1987. Decommissioning:Conceptual Studv. in Situ Decommissioning of Eight 105 Reactor Buildings in the 100 Areas. UNI-2898 REV 0, UNC Nuclear Industries, Richland, Washington. 57 p., App. A through J.

Abstract: Deactivated reactors, used to produce plutonium from 1944 to 1971 on the Hanford Site, will be decommissioned. Work will be done by three parties. UNC will do the radiological characterization, all the decontamination and decommissioning non-explosive destruction, as well as contaminant fixing and void filling. One offsite contractor will destroy concrete walls with explosives, another will construct the burial mound. The earthen mounds will be $16 \mathrm{ft}$ deep over the reactors, and are designed to last at least 500 years. Total estimated cost is $\$ 42,760,00$ and estimated time to complete is 5 years.

Kev Words: HANFORD SITE - deactivated reactors, reactor decommissioning, planning document, 100 Areas
Kalder, R. A., E. W. McDaniel, and R. L. Treat. 1985. "Immobilization of Selected Low-Level Hanford Wastes in Grout." In Waste Management 1985, Vol. I, ed. R. G. Post, pp. 185-191. University of Arizona Press, Tucson, Arizona.

Abstract: The DOE and Rockwell are preparing to construct a transportable grout facility to immobilize selected radioactive liquid waste stored on the Hanford Site. Immobilization is cost effective and environmentally sound. Immobilization solidifies the waste by mixing them with a blend of cementitious dry solids that consists largely of cement, fly ash, and clay. The grout formulation process, the grout facility and near-surface disposal site, and the assessment and verification work is described. Startup is planned for 1986.

Kev Words: EFFLUENTS AND WASTES Hanford Site, grout treatment facility, remedial plans, waste treatment

\section{$\mathrm{K}-3$}

Kasper, R. B. 1981. "Field Study of Plutonium Transport in the Vadose Zone." RHO-SA-224, Rockwell Hanford Operations, Richland, Washington. 20 p.

Abstract: The spatial distribution of plutonium and americium beneath the $216-Z-12$ crib (Z-12 crib) was examined. This crib received "low-salt" aqueous waste from 1959 to 1973, when it was retired from service. During its active life, $2.8 \times 10^{-8} \mathrm{~L}$ of aqueous waste containing $15.1 \mathrm{~kg}$ of plutonium entered the crib. Distribution of plutonium and americium was determined by drilling wells in and around the crib, using special techniques for obtaining samples of contaminated sediment. The highest concentration of plutonium (about $5 \times 10^{6} \mathrm{pCi} / \mathrm{g}$ ) occurred in sediment directly underneath 2-12 crib. Concentrations decreased rapidly with depth. Three meters below the crib, plutonium activity was less than $10-3 \mathrm{pCi} / \mathrm{g}$; at $12 \mathrm{~m}$ below, it was less than $1 \mathrm{pCi} / \mathrm{g}$. An increase in Pu activity occurred from 30 to $36 \mathrm{~m}$ below 2-12 crib when a silt unit appeared. The higher activity was probably related to the greater sorption capacity of the silt. Results indicated no breakthrough of plutonium to ground water. 
Kev Words: EFFLUENTS AND WASTES - americium, plutonium, radioactive waste, remedial assessment, TRU waste, 200 Area, 216-2-12 crib

\section{K-4}

Kasper, R. B. 1981. 216-2-12 Crib Status Report. RHO-LD-166, Rockwell Hanford Operations, Richland, Washington. 43 p., App. A through D.

Abstract: The 216-2-12 crib, an underground disposal facility, received an aqueous mixture classified as a "low-salt" waste (dilute sodium, fluoride, and nitrate) contaminated with plutonium. Prior to discharge, the solution was collected in holding tanks and neutralized to $\mathrm{pH} 8$. From 1959 to 1973 , the crib received an estimated $25.1 \mathrm{~kg}$ of plutonium in $2.8 \times 10^{-8} \mathrm{~L}$ of liquid. The crib was retired from service in 1973 . Laboratory studies indicate that plutonium in a dilute, neutral solution would be strongly sorbed onto sediments within a few meters of the discharge beneath the crib. Preliminary field studies confirmed this prediction.

Kev Words: EFFLUENTS AND WASTES - plutonium, radioactive waste, remedial assessment, TRU waste, 200 Areas, 216-2-12 crib

\section{$\mathrm{K}-5$}

Kasper, R. B. 1982. 216-Z-12 Transuranic Crib Characterization: Operational Historv and Distribution of Plutonium and Americium. RHO-ST-44, Rockwell Hanford Operations, Richland, Washington. $107 \mathrm{p}$.

Abstract: The 216-2-12 crib received "low-salt" aqueous waste from 1959 to 1973, when it was retired. About $2.8 \times 10^{-8} \mathrm{~L}$ of liquid containing 25.1 $\mathrm{kg}$ of plutonium entered the crib. Americium activity was derived from the in situ decay of ${ }^{241} \mathrm{Pu}$. No other TRU elements were discharged to the crib in significant amounts. Plutonium concentrations were highest ( 1 to $5 \times 10^{-6} \mathrm{pCi} / \mathrm{g}$ of sediment) immediately below the crib, and decreased rapidly with distance from the bottom. Activity was less than $1,000 \mathrm{pCi} / \mathrm{g}$ of sediment $3 \mathrm{~m}$ below the crib, and less than $1 \mathrm{pCi} / \mathrm{g}$ at $10 \mathrm{~m}$. However, plutonium activity increased to a few tens of $\mathrm{pCi} / \mathrm{gm}$ at 30 to $36 \mathrm{~m}$, in association with a silt unit at that depth having greater sorption capacity. Measurable concentrations of plutonium did not reach ground water.

Kev Words: EFFLUENTS AND WASTES - americium, plutonium, radioactive waste, remedial assessment, TRU waste, 200 Areas, 216-Z-12 Crib

\section{K-6}

Kennedy, W. E., Jr., and B. A. Napier. 1983. Allowable Residual Contamination Levels for Decommis-

Site. PNL-4704,Pacific Northwest Laboratory, Richland, Washington. 52 p., App. A and B.

Abstract: Data on Allowable Residual Contamination Levels (ARCL) are provided for UNC engineers to compare safety and costs of alternatives for decommissioning $115-\mathrm{F}$ and $117-\mathrm{F}$ facilities in the 100 Areas. Results were based on a scenario/exposurepathway analysis and compliance with an annual dose limit for three future land and facility uses restricted, controlled, and unrestricted. Procedures were presented to modify ARCL values to accommodate changes in radionuclide mixture or concentrations, and to determine responses of instruments for various radionuclide mixtures. Finally, the ARCL values calculated for unrestricted use of the $115-\mathrm{F}$ and 117-F facilities were compared with existing decommissioning guidance. Agreement was good.

Kev Words: HANFORD SITE - Allowable Residual Contamination Levels (ARCL), deactivated reactors, reactor decommissioning, regulatory compliance, 100 Areas

\section{K-7}

Kennedy, W. E., Jr., and B. A. Napier. 1983. Allowable Residual Contamination Levels for Decommissioning Facilities in the 100 Areas of the Hanford Site. PNL-4722, Pacific Northwest Laboratory, Richland, Washington. 78 p., App. A and B.

Abstract: Data on Allowable Residual Contamination Levels (ARCL) are provided for UNC engineers in comparing safety and costs of alternatives for decommissioning 100 Area reactor facilities. The ARCL results were based on scenario/exposure 
pathway analysis and compliance with an annual dose limit for three modes of future land and facility use - restricted, controlled, and unrestricted. Results were presented both for surface contamination remaining in facilities, and for unconfined surface and confined subsurface soil conditions. Worksheets allow for modifying ARCL values to accommodate changes in radionuclide mixture or concentration, to consider effects of radioactivedecay, and to predict instrument responses. Finally, unrestricted ARCL values for the shutdown 100 Area facilities were compared with existing decommissioning and land disposal regulations.

Kev Words: HANFORD SITE - Allowable Residual Contamination Levels (ARCL), deactivated reactors, reactor decommissioning, regulatory compliance, 100 Areas

\section{$\mathrm{K}-8$}

Kincaid, C. T., and P. J. Mitchell. 1986. $\underline{\text { Review of }}$ Multiphase Flow and Pollutant Transbort Models for the Hanford Site. PNL-6048, Pacific Northwest Laboratory, Richland, Washington. Irregular pages.

Abstract: Process models and computer codes for modeling multiphase ground-water flow and solute transport for the Hanford Site were reviewed in support of present onsite characterization and monitoring designs. Four approaches had been used to model transport of solutes in a single-fluid (usually) or multiphase fluid movement. Approaches included: 1) the classical advection-dispersion model, 2) the kinematic pathline model, 3) the mobile-immobile model with the advection-dispersion approach, and 4) stochastically based models. The variety of approaches suggest that unresolved questions remain on transport in single-fluid phase systems.

Several solutions were recommended. First, a geohydrologist with modeling experience should be hired to conduct all site-specific modeling; specifically, to sort through hundreds of available codes and adapt their best features to the Hanford Site. Second, parameters must be identified for field measurements to correspond to input needs of various solute transport models. Third, mechanistic release models should be used when sufficient data exist, because the rate and duration of release can greatly affect transport simulation. Finally, knowledge of processes and reactions of single-phase and multiphase flow and solute transport, and their mathematics, should be advanced to address multiphase transport issues.

Kev Words: GEOLOGY AND HYDROLOGY computer modeling, ground-water movement, information needs, solute transport models

\section{K-9}

Kirkham, R. R., G. W. Gee, and J. L. Downs. 1987. Field Lvsimeter Test Facility for Protective Barriers: Experimental Plan. PNL-6351, Pacific Northwest Laboratory, Richland, Washington. $37 \mathrm{p}$.

Abstract: The ability of barriers over waste disposal sites to minimize water infiltration can be tested with a Field Lysimeter Test Facility (FLTF) located near the HMS, 200 Areas. Eighteen lysimeters (14 drainage-type and 4 weighing-type) are under construction. When the lysimeters are filled with soil and rock materials that can be used as protective barriers, drainage can be measured at an estimated precision of $+/-0.04 \mathrm{~cm} / \mathrm{yr}$. Water storage and evapotranspiration can be monitored with gamma probes, neutron probes, and direct weighing. Additionally, data on soil water potential and soil temperature will be collected. The data sets will be used to calibrate models to assist in predicting long-term (10,000-yr) bamer performance. Precipitation changes will be simulated by evaluating barrier performance at normal, twice normal, and precipitation-to-failure conditions. Impacts of vegetation, bare soil, and gravel admix on evapotranspiration from the barrier site can be evaluated. When completed June 30,1987, the FLTF was the largest lysimeter facility at Hanford constructed with DOE funds.

Kev Words: GEOLOGY AND HYDROLOGY evapotranspiration, Field Lysimeter Test Facility (FLTF), lysimeter performance, 200 Areas

\section{K-10}

Kirkham, R. R., G. W. Gee, and T. L. Jones. 1984. "Weighing Lysimeters for Long-Term Water Balance Investigations at Remote Sites." Soil Sci. Soc. Am. L 48:1203-1205. 
Abstract: Two weighing lysimeters were installed at a remote location on the Hanford Site. Platform-type electronic scales were placed below the surface to measure the weight changes of a large (about $7 \mathrm{mg}$ ) container of soil. The load cells of the scales were exposed to high humidity and periodic contact with drainage water, but operated without failure for over five years. Weight changes are continuously recorded, with hourly averages transmitted by phone line directly to the laboratory. The sensitivity of the scale is $50 \mathrm{~g}$, equivalent to $0.02 \mathrm{~mm}$ of water.

Kev Words: GEOLOGY AND HYDROLOGY lysimeterfacilities, lysimeter performance

\section{K-11}

Kirkham, R. R., G. W. Gee, D. M. Nelson, and M. Curl. 1984. "Measurement of Unsaturated Flow Below the Root Zone at an Arid Site." In EPA Conference on Characterization and Monitoring of the Vadose Zone, pp. 917-935. National Water Well Association, Dublin, Ohio.

Abstract: Changes in moisture content below the root zone were measured in a grass-coveredarea on the semi-arid Hanford Site. Drainage exceeded $5 \mathrm{~cm}$ or $20 \%$ of the total precipitation from November 1982 through October 1983, which was an unusually wet year. Moisture content peaked at all depths and the monthly average potential evapotranspiration reached minimum November through April, when nearly $75 \%$ of the precipitation fell. Grass roots were not found below $1 \mathrm{~m}$, so moisture changes below that level were assumed to be related to drainage. Upward capillary action was considered negligible, since the soil was coarse sand and the water table was below $10 \mathrm{~m}$. Unsaturated flow model simulations predicted about

$5 \mathrm{~cm}$ of drainage from the grass site. Improved comparisons between measured and predicted drainage are expected with field-measured hydraulic properties and more realistic estimates of grass-cover transpiration.

Kev Words: GEOLOGY AND HYDROLOGY evapotranspiration, ground-water recharge, precipitation effects, unsaturated (vadose) zone
Klem, M. J. 1988. Inventory of Chemicals Used at Hanford Production Plants and Supoort Operations (1944-1980). WHC-EP-0172, Westinghouse Hanford Company, Richland, Washington. 58 p.

Abstract: A complete list of chemicals used in the production facilities and support operations of the DOE's Hanford Site was compiled to aid plans for characterizing the radioactive liquid chemical wastes stored in the 149 single-shell tanks. This list was compared to a list provided by regulatory agencies to identify the hazardous chemical constituents in the single-shell tank sampling program. The chemical list was based on chemical process flowsheets, essential material consumption records, letters, reports, and other historical data.

Kev Words: EFFLUENTS AND WASTES hazardous materials, hazardous waste management, radioactive liquids, remedial assessment, single-shell tanks, waste characterization,200 Areas

\section{K-13}

Klepper,E. L., K. A. Gano, and L. L. Cadwell. 1985. Rooting Denth and Distributions of Deep-Rooted Plants in the 200 Area Control Zone of the Hanford Site. PNL-5247, Pacific Northwest Laboratory, Richland, Washington. 12 p., App. A.

Abstract: Rooting depths and root distributions were documented for deep-rooted plants common to the 200 Area plateau. Effort concentrated on excavating plants suspected of having deep root systems, and species reported to contain radionuclides in emergent parts. Fourteen species (58 individual plants) were excavated. Eight of the 14 species had an average rooting depth of at least $150 \mathrm{~cm}$. Average rooting depths were $296 \mathrm{~cm}$ for antelope bitterbrush, $200 \mathrm{~cm}$ for sagebrush, $183 \mathrm{~cm}$ for gray rabbitbrush, $172 \mathrm{~cm}$ for Russian thistle, and $162 \mathrm{~cm}$ for bursage. These data will be useful for modeling radionuclide transport and designing covers and barriers for waste burial sites.

Kev Words: TERRESTRIALECOLOGY - plant community, rooting depth, waste burial sites, 200 Areas 
Landeen, D. S., and R. M. Mitchell. 1981. "Invasion of Radioactive Waste Burial Sites by the Great Basin Pocket Mouse (Perognathusparvus)." In International Symoosium on Migration in the Terrestrial Environment of Long-Lived Radionuclides from the Nuclear Fuel Cvcle, IAEA-SM-2571 58P, International Atomic Energy Agency, Vienna, Austria.

Abstract: The Great Basin pocket mouse has penetrated sites containing buried radioactive wastes at Hanford. Animals dug deeper in a backfilled site, probably because of limited compaction, than in the control site. Correlations were significant at both sites between burrow depth and soil volume, and between mound diameter and soil volume. Therefore, the burrowing depth and soil volume removed can be estimated without excavating. Results can be applied to design of future burial facilities to prevent or mitigate encroachment by burrowing animals.

\section{Kev Words: EFFLUENTS AND WASTES .} biological intrusion, radioactive waste, waste burial sites

\section{L-2}

Landeen, D. S., and R. M. Mitchell. 1982. "The Role of Burrowing Activities of the Great Basin Pocket Mouse (Perognathusparvus) in the Dispersal of Radionuclides on a DecommissionedPond." RHO-HS-SA-10 P, Rockwell Hanford Operations, Richland, Washington.

Abstract: Features associated with burrowing activities of the Great Basin pocket mouse on the Hanford Site were examined. Mice burrowed deeper in a backfilled burial site ( $72 \mathrm{~cm}$ average) than in the control site ( $38 \mathrm{~cm}$ average). The small amounts of ${ }^{137} \mathrm{Cs}$ in the mice were an order of magnitude below what was in the mounds. Burrowing and mound construction by mice may be more important than body tissue contamination in dispersing radionuclides. The ${ }^{137} \mathrm{Cs}$ values in mice and their mounds were below Rockwell surface soil contamination limits. Test plots will be used to develop control methods. Meanwhile, the surface of waste sites is being stabilized to control and deter burrowing animals.
Key Words: EFFLUENTS AND WASTES - cesium, biological intrusion, biotransport, radioactive waste, waste burial sites

\section{L-3}

Larson, J. 1985. Hvdrothermal Field Studv of Cooling Water Diffuser Outfall Hanford Generating Station. Prepared for Washington Public Power Supply System by Alden Research Laboratory, Worchester Polytechnic Institute, Holden, Massachusetts. $19 \mathrm{p}$.

Abstract The effects of a new multiport diffuser on HGP's cooling water discharge line were evaluated to determine if the outfall met existing thermal discharge criteria. Instruments and methods used in a 1984 field survey are described, then data reduction, model evaluation, and results are discussed. The imposed temperature limit apparently could be met at river flows down to the minimum legal low flow of $36,000 \mathrm{cfs}$.

Kev Words: HANFORD SITE - environmental assessment, cooling water discharge, HGP operation, Hanford Reach, outfall diffuser design

\section{$\mathrm{L}-4$}

Larvie, F. C. 1984. "Construction of a Nuclear Waste Repository in Basalt at Hanford, Washington." In Waste Management '84. Proceedings of the Symposium on Waste Management, Vol. 1 Waste Policies and Programs, High-Level Wastes, ed. R. G. Post, pp. 247-249. University of Arizona Press, Tucson, Arizona.

Contents: Drilling of the exploratory shaft in basalt at Hanford was delayed beyond its scheduled start of March 1985 by requirements of the Nuclear Waste Policy Act. This paper reviews plans for completing the exploratory shaft and the underground excavation work planned for site characterization, and ends with an overview of the conceptual design for a nuclear waste repository in basalt.

Kev Words: HANFORD SITE - BWIP site, exploratory shaft, geologic repository, planning document 
Last, G. V. 1983. "Radionuclide Distribution Around a Low-Level Radioactive Waste Disposal Pond and Ditch System at the Hanford Site." In Waste Management'83 Proceedings of the Symposium on Waste Management, Vol. 2, ed. R. G. Post, pp. 323-329. University of Arizona Press, Tucson, Arizona.

Abstract: The 216-U-10 (U) pond and 216-Z-19 (Z19) ditch are used for disposal of large volumes of low-level radioactive liquids on the Hanford Site. They represent a system of ditches, ponds, and ovefflow facilities collectively called the $U$ pond disposal system. This system has been used since 1943, and has received a large variety of radionuclides from several sources.

Long-term use of $U$ pond and Z-19 ditch has localized the accumulation of TRU and fission products through sorption and filtration of particulates in upper sediments. The most widely distributed radionuclide, ${ }^{137} \mathrm{Cs}$, was used as an index radionuclide to define the maximum extent of contamination. The $400 \mathrm{pCi} / \mathrm{g}$ isopleth showed a surface contamination of about 19 ha at $\mathrm{U}$ pond and the 216-U-11ovefflow basin. Contamination was localized in the top $10 \mathrm{~cm}$ of soil and decreased rapidly with depth. The Z-19 ditch and its backfilled predecessors, the 216-Z-11 (Z-11) and 216-Z-1 (Z-1) ditches received discharges of ${ }^{238 / 239 / 240} \mathrm{Pu}$ and ${ }^{241} \mathrm{Am}$ from the 234-5Z and 231-Z facilities, and they retained more than $90 \%$ of the plutonium inventory discharged to the $\mathrm{U}$ pond system.

Kev Words: EFFLUENTS AND WASTES - americium, cesium, plutonium, radioactive waste, remedial studies, soil sorption (in situ), Z-19 ditch, 200 Areas

\section{L-6}

Last, G. V., M. A. Glennon, M. A. Young, and G. W. Gee. 1987. Protective Barrier Materials Analvsis: Fine Soil Site Characterization. PNL-6314, Pacific Northwest Laboratory, Richland, Washington. 33 p., App. A through E.

Abstract: Soil samples at the McGee Ranch, a potential quarry site to provide fine-soils for protective barriers, were collected for physical characterization. Forty borings were made with a hollow-stem auger to a depth of $10 \mathrm{~m}$ or the first main gravel layer, whichever was first reached. Field moisture content and grain-size distribution were determined, and the samples were classified into one of 19 sediment classes. Physicalcharacterizationindicated that about 3.4 $\mathrm{Mm}^{3}$ (million cubic meters) of soil met or exceeded the minimum grain-size criteria for fine soils needed in protective barriers over wastes sites at Hanford.

Kev Words: EFFLUENTS AND WASTES - soil barriers, remedial plans, waste burial sites

\section{L-7}

Last, G. V., and T. L. Liikala. 1987. AField Guide for Well Site Geologists: Cable Tool Drilling. PNL6392, Pacific Northwest Laboratory, Richland, Washington. 25 p., App. A and B.

Abstract: A large number of monitoring wells are being drilled at Hanford to bring hazardous waste sites in compliance with RCRA. This effort requires support from well site geologists to document geohydrologic conditions and well construction. PNL's technical procedure for collection of drilling data defines the data collection and documentation procedures to be followed. This field guide provides detailed information and examples.

\section{Kev Words: GEOLOGY AND HYDROLOGY -} drilling technique, geohydrologic assessment, Hanford Site, monitoring wells, stratigraphy

\section{L-8}

Laul, J. C., M. R. Smith, V. G. Johnson, and R. M. Smith. 1985. "Disequilibrium of Natural Radionuclides in Hanford Site Groundwater." In High-Level Nuclear Waste Disposal, ed. H. C. Burkholder, pp. 401-410. Battelle Press, Richland, Washington.

Abstract: Concentrations of uranium, thorium, radium, lead, and polonium radionuclidesare extremely low in well DC-14 ground water (basalt flowtop aquifer) of the Grande Ronde Formation, 994 to $1017 \mathrm{~m}$ below the surface on the Hanford Site. Uranium, thorium, and radium appear to be highly sorbed. Relative to radon, the retardation factors are: 1200 for uranium, 12,000 for thorium, and 1500 for radium in DC-14 water. The ${ }^{234} \mathrm{U} /{ }^{230} \mathrm{Th}$ ratio is about 10 in DC-14 well water and about 240 in nearby 
Columbia River water, indicating that uranium is largely in the 4+ oxidation state and implying a reducing environs in the well water. Colloids appear to be important for lead and polonium, but not for uranium, thorium, and radium in water from the well.

Kev Words: RADIOACTIVITY - background radiation, ground-water transport, Hanford Site, physicochemical properties, radionuclides

\section{L-9}

Law, A. G., and R. M. Allen. 1984. Results of Separation Area Ground-Water Monitoring:Network for 1983. RHO-RE-SR-84-24P, Rockwell Hanford Operations, Richland, Washington. 53 p., App. A through E.

Abstract: The monitoring network in the 200 Areas contained 112 wells in 1983. New wells drilled during the year were added when completed. Water samples from the wells were collected monthly, quarterly, or semiannually depending on waste disposal site. Samples were analyzed selectively for total alpha, total beta, tritium, ${ }^{90} \mathrm{Sr},{ }^{137} \mathrm{Cs},{ }^{60} \mathrm{Co},{ }^{106} \mathrm{Ru}$, uranium, and nitrate. Average concentrations of radionuclides in ground water were essentially the same as they were in CY 1982. Tritium was higher than guidelines at one active waste site, the 216-A-36 B crib. Strontium-90 levels were greater than guidelines at two inactive disposal sites, the 216-B-5 reverse well and the 216-S-1 and 216-S-2 cribs. Ground-water plume maps for total beta, tritium, and nitrate revealed only minor changes.

Kev Words: HANFORD SITE - environmental monitoring, ground water, radioactivity, waste disposal sites, well-water samples, 200 Areas

\section{L-10}

Law, A. G., and A. L. Schatz. 1986. Results of the Separations Area Ground-Water Monitoring:Network for 1985. RHO-RE-SR-86-24P, Rockwell Hanford Operations, Richland, Washington. 88 p., App. A through $\mathrm{E}$.

Abstract: The monitoring network in the 200 Areas contained 127 wells in 1985 . Water samples were collected and analyzed selectively for important radionuclides: total alpha, total beta, ${ }^{3} \mathrm{H},{ }^{90} \mathrm{Sr},{ }^{137} \mathrm{Cs}$,
${ }^{60} \mathrm{Co},{ }^{100} \mathrm{Ru}$, uranium, and nitrate. Average concentrations of radionuclides in ground water were similar to those in 1984, except for wells at the 216-U-1 and 216-U-2 cribs. Water table maps were prepared for the Hanford Site and Separations Area. Tritium levels, controlled by regulating discharge concentration, did not exceed radioactivity levels specified in RHO-MA-139 (Rockwell guidelines). Guidelines for contaminants were exceeded in some cases at both active and inactive waste disposal sites. Remedial action was taken for uranium in ground water at the 216-U-1 and 216-U-2 cribs. Levels of $238 \mathrm{U}$ beneath the 216-U-10 pond (deactivated in 1984) exceeded guidelines in three wells but had not changed since 1984.

Kev Words: HANFORD SITE - environmental monitoring, ground water, radioactivity, waste disposal sites, well-water samples, 200 Areas

\section{L-11}

Law, A. G., A. L. Schatz, M. R. Fuchs, and K. L. Dillon. 1986. Results of the Separations Area Ground-Water Monitoring:Network for 1984. RHORE-SR-85-24P, Rockwell Hanford Operations, Richland, Washington. 143 p., App. A through D.

Abstract: The monitoring network in the 200 Areas contained 127 wells in 1984 in or adjacent to liquid waste disposal sites. Water samples were collected and analyzed selectively for important radionuclides. Average radionuclide concentrationsin monitoring wells were similar to 1983 . Water level maps were prepared for the Hanford Site and Separations Area. Levels of mtium did not exceed levels specified in RHO-MA-139 (Rockwell guidelines). At active sites, DOE guidelines (DOE Order 5480.1, XI-I) and/ or Rockwell guidelines were exceeded at: 1) three wells at the 216-A-25 pond (average ${ }^{90} \mathrm{Sr}$ concentration), deactivated in 1984; 2) three wells at the 216B-62 crib $\left({ }^{234} \mathrm{U}\right.$ and $\left.{ }^{238} \mathrm{U}\right)$; and 3$)$ three wells at the 216-U-10 pond $\left({ }^{238} \mathrm{U}\right)$, deactivated in 1984 . At inactive sites, DOE and/or Rockwell guidelines were exceeded at: 1) the $216-\mathrm{B}-5$ reverse well $\left({ }^{9} \mathrm{Sr}\right.$ and $\left.\left.{ }^{137} \mathrm{Cs}\right), 2\right)$ one well $\left({ }^{90} \mathrm{Sr}\right)$ at the inactive $216-\mathrm{S}-1$ and 216-S-2 cribs; and 3) the inactive 216-S-1 and 216-S2 cribs, when total alpha concentrationsexceeded guidelines in the last 1984 sample. 
Kev Words: HANFORD SITE - environmental monitoring, ground water, radioactivity, waste disposal sites, well-water samples, 200 Areas

\section{L-12}

Law, A. G., J. A. Serkowski, and A. L. Schatz. 1987. Results of the Separations Area Ground-Water Monitoring Network for 1986. RHO-RE-SR-87-24P, Rockwell Hanford Operations, Richland, Washington. 96 p., App. A through D.

Abstract: The monitoring network in the 200 Areas consisted of 137 wells in 1986. Water samples were collected and analyzed selectively for important radionuclides. contamination levels were compared with DOE's interim derived concentration guides (DCG) and Rockwell's administrative control limits (ACL), derived from the ALARA concept. In addition, the water table and nitrate plume were mapped. Generally, contaminations were localized and would be reduced below guidelines before reaching the Columbia River.

At active disposal sites: 1) tritium levels exceeded DCGs beneath the 216-A-10 and 216-A-36B cribs; 2 ) the average ${ }^{90} \mathrm{Sr}$ concentrationsexceeded ACLs in three wells at the 216-A-25 pond, but remained below DCG limits; 3 ) ${ }^{234} \mathrm{U}$ and ${ }^{238} \mathrm{U}$ levels exceeded ACLs in two wells at the 216-B-62 crib; and 4) uranium levels exceeded ACLs in a well at the 216-U-14 ditch, but were below DCGs, when monitoring was initiated in 1986.

At inactive disposal sites: 1) ${ }^{90} \mathrm{Sr}$ levels exceeded DCGs and ACLs at the 216-B-5 reverse well, while levels of ${ }^{137} \mathrm{Cs}$ and uranium exceeded ACLs but were below DCGs; 2) ${ }^{90} \mathrm{Sr}$ levels exceeded ACLs at one well at the 216-S-1/2 cribs, but were below DCGs; 3) uranium levels remained above the DCGs and ACLs beneath the $216-\mathrm{U}-1 / 2$ cribs, 4$){ }^{129} \mathrm{I}$ levels exceeded ACLs, but was below DCGs, at one well east of the 200 West area; and 5) uranium levels exceeded ACLs, but were below DCGs, at three wells at the 216-U-10 pond (deactivated in 1985) and at a well nearby at the 216-S-21 crib.

Kev Words: HANFORD SITE - environmental monitoring, ground water, radioactivity, waste disposal sites, well-water samples, 200 Areas
Leaming, G. F., and J. D. Davis. 1983. "Mineral Resource Analysis of the Proposed Site for Underground Storage of High-Level Commercial Nuclear Waste, Hanford, Washington." In Waste Management '83, Proceedings of the Svmoosium on Waste Management. Vol. 2, ed. R. G. Post, pp. 235-241. University of Arizona Press, Tucson, Arizona.

Abstract Known and potential mineral resources were examined at the Hanford Site and within 100 $\mathrm{km}$ of Hanford to help evaluation of the candidate site for a geologic repository. Current mining is limited to surface-mined diatomaceousearth, sand and gravel, and stone. Relatively low-unit-value minerals consist of peat, diatomaceous earth, pumicite, quarry rock, and sand and gravel. A small, lowpressure natural gas field, in production from 1929 to 1941, lies at the southern edge of the Hanford Site. No other commercial production of fossil fuels has occurred in the area. Except for small, low-grade gold placers along the Columbia River, no high-unitvalue minerals are present. Economic analysis of the area within $100 \mathrm{~km}$ of the candidate repository indicates the gross value of known mineral resources and potential, undiscovered natural gas within Columbia River basalts is $\$ 470.5$ million. Subtracting development and related costs, the net value of these resources is $\$ 33.3$ million. The projected net value per area and per capita averages $\$ 569 / \mathrm{km}^{2}$ and $\$ 62 /$ person. These are relatively low values. Mineral resources in the area are likely to remain an unimportant part of employment, personal income, and tax revenues.

\section{Kev Words: GEOLOGY AND HYDROLOGY -} Hanford Site, identification, mineralology, socioeconomic value

\section{L-14}

Leopold, E. B. 1987. "Past and Future Climatic and Hydrologic Patterns at Hanford, Washington." Northwest Environ. I. 3:75-96.

Abstract: In the recent past, the Columbia Basin has experienced large, natural changes in precipitation, temperature, evaporation and probable ground-water flow rates, as well as massive floods. A comprehensive scheme upon which to base predictions for future 
hydrologic conditions must include: 1) a valid working model of the current ground-water system, 2) a fairly complete pollen record over the past 30,000 years, and 3) a climatic calibration of fossil sites with modem pollen rain studies. A comprehensive hydrologic model, with input of temperatures and precipitation from the past, can provide a proper basis for calculating ground-water travel times under different worst-case conditions. The DOE's current hydrologic model for the Hanford Site is critically examined.

Kev Words: AIR AND ATMOSPHERE- information needs, climate, Hanford Site, historical review, hydrology, precipitation

\section{L-15}

Liebow, E. B., J. A. Fawcett-Long, and E. S. Terrill. 1987. Understanding Socioeconomic Aspects of Risk Perception, Progress Report FY-1987. Working Draft, BWIP Repository Project. PNL-6382

(BHARC-800/87/023), Pacific Northwest Laboratory, Richland, Washington. $84 \mathrm{p}$.

Contents: This report summarizes progress in understanding risk perception and its implications for the suitability of the Hanford Site as a location for an underground repository for radioactive waste (BWIP). It reviews the professionalliterature and presents some observations about causes, consequences, and processes of risk perception. It also contains an extensive bibliography of references, and compiles abstracts from selected articles relevant to BWIP and its institutional support. Several "lessons learned" are discussed. For example, the term "risk" has different meanings in different research contexts and for different interest groups. Thus, misunderstandings arise when various parties use the same term. Also, differences in perception of "risk" result from differences in knowledge or expertise, differences in values or definition, and disagreements about facts.

Key Words: SOCIOECONOMIC - effect of BWIP, public viewpoints, risk perception

\section{L-16}

Liebow, E. B., C. A. Younger, and J. A. Broyles. 1987. A S ynthesis of Ethnohistorical Materials
Concerning the Administration of Federal Indian Policv Among the Yakima. Umatilla and Nez Perce Indian People. Working Draft, BWIP Reference Repository. PNL-6381 (BHARC-800/87/022), Pacific Northwest Laboratory, Richland, Washington. $45 \mathrm{p}$.

Contents: This historical analysis summarizes information from the reports of field agents to the Commissioner of Indian Affairs (1855-1936), and the dockets of the Indian Claims Commission. These sources help explain the administration of federal Indian policy, which has a major role in shaping economic development of the affected Indian tribes (in relation to the BWIP). As analysis progresses, material will be included from additional sources. When completed, the analyses will give historic and regional perspective to the possible effects of a geological repository at Hanford on various cultural features of the tribes.

The current report gives information on the establishment of reservations in the mid-1850's. the early reservation period, and the allotment period up to the early 1930's. Analysis in the coming fiscal year will initially emphasize the traditional spiritual practices and persistence of traditional secular pursuits. Other features will be examined later.

Kev Words: SOCIOECONOMIC - affected Indian tribes, ethnohistoric data, federal Indian policy, relations to BWIP

\section{L-17}

Liikala, T. L., D. S. Daly, and A. P. Toste. 1988. An Evaluation of the Effects of Well Construction Materials and Ground-Water Sampling Equinment on Concentrations of Volatile Organic Compounds. PNL-6585, Pacific Northwest Laboratory, Richland, Washington. $25 \mathrm{p}$.

Abstract: In 1985, ground-water samples were collected from two monitoring wells in an area of known contamination. Sampling was conducted for 4 weeks with three dedicated sampling devices. Each sample was analyzed for volatile organic content, and the data were statistically analyzed to determine differences in contaminants resulting from well construction materials and ground-water sampling devices. No statistically significant differences appeared as a result of well construction and sampling devices. 
Analyses indicated a correlation between constituent concentration and sample data and, to a lesser degree, water table elevation. The range in concentrations during the study was greater than the differences caused by the two wells and three sampling devices.

Kev Words: HANFORD SITE - environmental monitoring, well sampling evaluation, well water samples

\section{L-18}

Lombardo, N. J., and LL. Eyler. 1982. Three-Dimensional Near-Field Analvsis of the N Reactor Thermal Discharge. FATE-82-111, prepared for UNC Nuclear Industries by Pacific Northwest Laboratory, Richland, Washington. 27 p., App. A and B.

Abstract: The TEMPEST computer code was used to simulate mixing of the thermal discharge from $\mathrm{N}$ Reactor near the plume release point in the center of the Hanford Reach. A buoyant discharge of 390,000 gpm (867 cfs) at the river bottom, $70^{\circ} \mathrm{F}\left(21.1^{\circ} \mathrm{C}\right)$ above ambient river temperature was modeled, corresponding to operation of $\mathrm{N}$ Reactor at 4000 MWt. TEMPEST showed a near-field mixing that started $45 \mathrm{ft}$ above the release point and extended 135 $\mathrm{ft}$ downstream, reaching to $50 \mathrm{ft}$ on either side of the plume centerline. A nominal river flow of $66,000 \mathrm{cfs}$ corresponded to a river depth at the outfall of $28.5 \mathrm{ft}$. Predicted temperaturesand velocities were given for two- and three-dimensional simulationsas a function of downstream, lateral, and depth position. Results showed the effect of three-dimensional mixing near the outfall and the extent of the near-field thermal plume. The effect of computational noding structure on the thermal plume was also examined.

Key Words: HANFORD SIIE - environmental assessment, cooling water discharge, Hanford Reach, TEMPEST model, thermal plume, $\mathrm{N}$ Reactor

\section{M-1}

Macbeth, P. J., and J. R. Allen. 1986. "Radwaste Experienceat WNP-2 - The First Two Years." In Waste Management '86. Proceedings of the Symnosium on Waste Management. Vol. 3 Low-Level Aste, ed. R.G. Post, pp. 307-311. University of Arizona Press, Tucson, Arizona.
Contents: Characteristics of radwastesand generation rates for waste filter sludges, spent resins, and dry active wastes produced at WNP-2 on the Hanford Site during its first 2 years of operation were presented. Factors leading to the initial and subsequent selection of vendors for radwaste processing services were identified. Future plans for handling radwaste generated at WNP-2 were discussed.

Kev Words: EFFLUENTS AND WASTES - lowlevel waste, radioactive waste management, waste characterization, waste generation, WNP-2,400 Area

\section{M-2}

Macbeth, P. J., and K. A. Smith. 1988. "Radwaste Experience at WNP-2 - The First Four Years." In Spectrom '88. Proceedings of the International Tonical Meeting on Nuclear and Hazardous Waste Management, pp. 95-98. American Nuclear Society, Inc., La Grange Park, Illinois.

Abstract: WNP-2 has a standard GE-supplied condensate polishing and liquid radwaste processing system using predominantly powdered resins with no regeneration. Its liquid waste management system is designed to collect, segregate, store, and process potentially radioactive liquids generated during normal plant operations and anticipated operational occurrences. The objective is to obtain maximum recycling and minimum release of radioactive liquids without limiting plant operations or availability. Volumes of filter sludge and spent resins generated at WNP-2 and shipped for disposal each month for the past 4 years are figured. Total activities and concentrations of the main nuclides in the waste have increased, as expected, over the last 4 years. The volumes of dry active waste generated each month average $15 \mathrm{~m}^{3}\left(550 \mathrm{ft}^{3}\right)$. Peaks in waste generation occur to major refueling and maintenance outages. Future plans include increasing the resin flow from about 360 to about $500 \mathrm{gpm}$, which will improve performance and change resin use and loading factors. A wet laundry is planned for the reactor building, which will increase the amount of detergent wastes.

Key Words: EFFLUENTS AND WASTES - lowlevel waste, radioactive liquids, radioactive waste management, waste characterization, waste generation, WNP-2, 400Area 
Mackey, D. B., and J. R. Divine. 1986. User's Guide to Waste Tank Corrosion Data Model Code. PNL-5766, Pacific Northwest Laboratory, Richland, Washington. $14 \mathrm{p}$.

Abstract: Corrosion tests of tank construction material for possible future use at Hanford were conducted. Tested were A-516 alloy steel (used in older single shell tanks) and A-537 alloy steel (used currently on double shell tanks) in three types of simulated wastes - double shell slurry, future PUREX, and Hanford facilities. The raw data on corrosion, gathered between $25^{\circ}$ and $180^{\circ} \mathrm{C}$, were statistically modeled for each waste, and a fourth model was developed for the combined data. Modeling procedures and details were given on how to access this information through a computerized data system.

Kev Words: EFFLUENTS AND WASTES - radioactive waste, remedial studies, steel-corrosion tests, waste storage tanks

\section{M-4}

Makhijani, A., K. M. Tucker, and D. E. White. 1985. Heat. High Water. and Rock Stabilitv at Hanford: A Preliminary Assessment of the Suitabilitv of the Hanford. Washington Site for a Hieh-Level Nuclear Waste Repository. Health and Energy Institute, Washington, D.C. 29 p.

Contents: This independent report by the Health and Energy Institute is a critique on the suitability of the Hanford Site for a nuclear waste repository. The report concludes: "The construction of a radioactive waste repository at Hanford and the subsequent placement of high-level wastes in it is likely to be a dangerous mining operation with possible high costs in lives and money. The geologic and hydrologic characteristics may be so adverse that the site could violate every one of the major performance standards required by the NRC. Moreover, the site may be so complex that it may be difficult to have reasonable confidence that it will contain the wastes, as required, even after long and expensive efforts at site characterization."
Kev Words: HANFORD SITE - BWIP Site, BWIP site critique, geologic repository, geohydrology

\section{M-5}

Marr, N. V., C. A. Brandt, R. E. Fitzner, and L. D. Poole. 1988. HabitatAssociations of Vertebrate Brev Within the Controlled Area Studv Zone. PNL6495, Pacific Northwest Laboratory, Richland, Washington. 22 p.

Abstract: This is one of seven Environmental Topical Reports produced by BWIP before the effort ended in late 1987. The reports provide environmental information on Hanford, then a possible site for the nation's first geologic repository for radioactive wastes.

Eight species of small mammals were captured at 12 locations in nine habitat types near the RRL. The most frequently caught were the Great Basin pocket mouse, followed by deer mice. Catches included the northern pocket gopher, western harvest mouse, grasshopper mouse, montane vole, house mouse, and bushy-tailed wood rat. Pocket mice were caught in all areas; deer mice were caught in all habitats except hopsage and nearly pure cheatgrass stands. Bitterbrush and riparian habitats had the highest capture rates. Data are given on sex ratios and body weights of small mammals.

Six species of reptiles and one species of amphibian were also captured. The side-blotched lizard was by far the most abundant at most sites. The northern sagebrush lizard and short-homed lizard were taken only from bitterbrush habitat. Snakes comprised $25 \%$ of all herptiles, and the yellow-bellied racer and the Great Basin gopher snake predominated. Only two specimens of one amphibian was captured, the Great Basin spadefoot toad at Rattlesnake Springs. Species diversity was low (Shannon-Wiener $=1.03)$.

Kev Words: TERRESTRIALECOLOGY - amphibians, BWIP site, habitat use, small mammals/rodents, relative abundance, reptiles 
Maas, L. J. 1981. Hanford Sanitarv Water Oualitv SurveillanceCY-1980. HEHF-33, Hanford Environmental Health Foundation, Richland, Washington. $21 \mathrm{p}$.

Abstract: The quality of drinking water on the Hanford Site is examined each year by the HEHF to protect human health. In 1980, potable water was supplied by 15 systems, each consisting of a raw water supply, treatment facilities, and distribution piping. Twelve systems used Columbia River water, two used ground water, and one (Richland municipal) used both. Individual systems were identified. Data showed continued compliance with applicable drinking water standardsfor inorganic, organic chemical, microbiological,and radiological materials.

Kev Words: HANFORD SITE - environmental monitoring, drinking water, ground water, river water, water quality

\section{M-7}

Maas, L. J. 1982. Hanford Sanitarv Water Oualitv Surveillance CY-1981. HEHF-36, Hanford Environmental Health Foundation, Richland, Washington. $22 \mathrm{p}$.

Abstract: The quality of drinking water on the Hanford Site is examined each year by the HEHF to protect human health. In 1981, potable water was supplied by 17 systems, each consisting of a raw water supply, treatment facilities, and distribution piping. Thirteen systems used Columbia River water, three systems used ground water, and one system (Richland municipal) used both. Individual systems were identified. Data generally complied with drinking water standards for inorganic, organic chemical, microbiological, and radiological materials. Exceptions were one microbiological sample related to a chlorinator failure at the Central Fire Station, and four samples from various locations that exceeded one or more secondary chemical or physical standards; all were related to piping deterioration and were not health concerns.

Kev Words: HANFORD SITE - drinking water, environmental monitoring, ground water, river water, water quality
Mass, L. J. 1983. Hanford Sanitarv Water Ouality SurveillanceCY-1982. HEHF-39, Hanford Environmental Health Foundation, Richland, Washington. $19 \mathrm{p}$.

Abstract: The quality of drinking water on the Hanford Site is examined each year by the HEHF to protect human health. In 1982, potable water was supplied by 18 systems, each consisting of a raw water supply, treatment facilities, and distribution piping. Thirteen systems used Columbia River water, four used ground water, and one (Richland municipal) used both. Individual systems were identified. Data generally complied with drinking water standards for inorganic, organic chemical, microbiological, and radiological materials. Exceptions were four samples from various locations that equaled or exceeded secondary chemical or physical standards; all were related to piping deterioration and were not a health concern.

Kev Words: HANFORD SITE - drinking water, environmental monitoring, ground water, river water, water quality

\section{M-9}

Maas, L. J. 1984. Hanford Sanitarv Water Oualitv SurveillanceCY-1983. HEHF-42, Hanford Environmental Health Foundation, Hanford, Washington. 16 P.

Abstract: The quality of drinking water on the Hanford Site is examined each year by the HEHF to protect the human health. In 1983, potable water was supplied by 17 systems, each consisting of a raw water supply, treatment facilities, and distribution piping. Twelve systems used Columbia River water, four used ground water, and one (Richland municipal) used both. Individual systems were identified. Inorganic chemicals in drinking water generally complied with health-based limits. Exceptions were for silver in the sample from the 200 Area and selenium in the sample from the 6652-C Building; multiple follow-up samples from both locations showed neither chemical. Coliform bacteria were detected in one sample from the 609 Building (follow-up samples were negative) and two samples from the 1170 Building, where contamination was 
related to extended retention of water in supply and distribution lines. No radiation standards were exceeded in any water supply.

Kev Words: HANFORD SITE - drinking water, environmental monitoring, ground water, river water, water quality

\section{M-10}

Maas, L. J. 1985. Hanford Sanitary Water Quality SurveillanceCY-1984. HEHF-45, Hanford Environmental Health Foundation, Richland, Washington. $20 \mathrm{p}$.

Abstract: The quality of drinking water on the Hanford Site is examined each year by the HEHF to protect human health. In 1984, potable water was supplied by 17 systems, each consisting of a raw water supply, treatment facilities, and distribution piping. Twelve systems used Columbia River water, four systems used ground water, and one system (Richland municipal) used both. Individual systems were identified. Data indicated general compliance with water quality standards for inorganic, organic chemical, microbiological, and radiological materials. Exceptions, all related to piping corrosion, were four samples that exceeded aesthetic limits for iron.

Kev Words: HANFORD SITE - drinking water, environmental monitoring, ground water, river water, water quality

\section{M-11}

McCormack, W. D., and J. M. V. Carlile. 1984. Investigation of Groundwater Seepage from the Hanford Shoreline of the Columbia River. PNL5289, Pacific Northwest Laboratory, Richland, Washington. 20 p., App. A through C.

Abstract: Areas were identified along the Hanford Reach shoreline where materials related to onsite activities were entering the Columbia River via ground water. The physical characteristicsand relative amounts of the seepages (springs) were evaluated. In Phase I, 115 springs were located along 41 miles of shoreline; all were accessibleonly when releases of water at Priest Rapids Dam were low. In Phase 11, water samples from the springs were collected and analyzed for constituents such as tritium and nitrate (as NO,), and for uranium near the 300 Area. Amounts in spring water samples were similar to those in nearby ground water. While some constituents were elevated in river water near the seepages, all concentrations were well below applicable DOE Concentration Guides.

Kev Words: HANFORD SITE - ground water, Hanford Reach, nitrate, radioactivity, shoreline springs, tritium

\section{M-12}

McCormack, W. D., J. M. V. Carlile, R. A. Peloquin, and B. A. Napier. 1983. A Combarison of Environmental Radiation Doses Estimated for Hanford Operations. 1977 Through 1982. PNL-4713, Pacific Northwest Laboratory, Richland, Washington. 16 p., App. A and B.

Abstract: One main objective of the Hanford Environmental SurveillanceProgram is to evaluate offsite environmental radiation dose equivalentseach year based on Hanford Site operations. This report compares calculated dose equivalents for 1977 through 1981 to those calculated for 1982. A downward trend appeared in calculated offsite doses from 1977 to 1982 , primarily a result of reductions in effluent releases, changes in effluent reporting methods, and increased flows in the Columbia River. Calculated doses verify the findings of the surveillance program, namely, that offsite radiation doses from Hanford operations are small, well below detectable levels.

Kev Words: RADIOACTIVITY - assessment, Hanford Site emissions, radiation data, radiation dose estimates

\section{M-13}

McCormack, W. D., J. V. Ramsdell, and B. A. Napier. 1984. Hanford Dose Overview Program:

mental Dose Calculations. PNL-3777 Rev. 1, Pacific Northwest Laboratory, Richland, Washington. 38 p., App. A and B.

Contents: The Hanford Dose Overview Program is administered by PNL for the DOE to ensure internal consistency of dose assessments for the entire Hanford Site. This report is a guide for Hanford 
contractors to perform or obtain dose calculations that are state-of-the-artand continually evolving. The report, therefore, needs to be updated at least annually. The current revision reflects changes made in methods used to calculate atmospheric dispersion of airborne effluents at Hanford. Modified data and models are described in detail, calculation methods are discussed, and calculation results are reviewed.

Kev Words: RADIOACTIVITY - airborne radioactivity, atmospheric dispersion, computer modeling, radiation dose estimates

\section{M-14}

McCorquodale, S. M. 1985. "Archaeological Evidence of Elk in the Columbia Basin." Northwest Sci. 59:192-197.

Abstract Traditionally,elk are considered to have been absent from the Columbia Basin during postglacial time. However, elk remains have been found at or near archaeological sites representing early human cultures in the area. Elk remains associated with remains of mostly steppe fauna suggest that elk were at least seasonal residents of the Columbia Basin during the last 10,000 years.

Kev Words: TERRESTRIAL ECOLOGY • Columbia Basin, elk, historical documentation

\section{M-15}

McCorquodale,S. M. 1985. The Ecoloev of Elk (Ceryus elaphus) in the Shrub-Steppe of Washington. M.S. Thesis, University of Washington, Seattle. 27 p.

Abstract: Elk, absent from the shrub-steppe of Washington during recent history, have lived on the ALE Reserve since 1972. Habitat use by elk on the reserve is determined by distribution and abundance of forage, human disturbance, and water sources for lactating females. Elk appear to tolerate hot climates if energy is sufficient for them to tolerate high thermoregulation. Sagebrush stands provide microclimates for elk to rest and ruminate. Macroclimates such as higher elevations on the ALE reserve are not used because preferred forage, water, and sagebrush are lacking. The animals forage primarily on abundant grasses during spring, early summer, and fall, and nonselectively on forbs during late summer and fall. Elk activity on the ALE Reserve during summer is largely nocturnal, in contrast to their activity in other areas. Overall, nutrient and energy intake by elk in the shrub-steppe is apparently sufficient for maintenance, growth, pregnancy, and lactation because the ALE population has a high reproduction and survival rate.

Kev Words: TERRESTRIALECOLOGY - ALE Reserve, behavior, ecological relations, elk, food and feeding, habitat use, thermoregulation

\section{M-16}

McCorquodale, S. M. 1987. "DesertElk of Washington." Bugle Mag. 4:30-31.

Abstract: Precipitation in the Great Plains peaks during summer when female elk are lactating. In western deserts, water is limited in the summer. Also, plant diversity is generally higher on the Great Plains and sod-forming grasses grow throughout the summer. Despite these differences, elk have increased on the ALE Reserve at Hanford since 1972 to about 70 animals. The ALE elk, in absence of extensive cover, use topographic features such as ravines and gullies, and often bed in sagebrush during the heat of day. The home range of ALE elk is as much as 10 times greater than the home range of elk in a more typical, forested area. Two small streams are the only source of water for ALE elk, and they produce needed forage late in summer when desert grasses are desiccated.

Kev Words: TERRESTRIAL ECOLOGY - ALE Reserve, behavior, ecological relations, elk, habitat use, home range, population increase

\section{M-17}

McCorquodale, S. M. 1987. "Fall-Winter Habitat Use by Elk in the Shrub-Steppe of Washington." Northwest Sci. 61:171-173.

Abstract: Habitat use by elk on the ALE Reserve was studied from October 1985 to March 1986. Elk wearing radiocollars selected habitat according to activity. Sagebrush/Sandberg's bluegrass areas were preferred by bedded (resting or ruminating) elk, while Sandberg's bluegrass and cheatgrass areas without sagebrush were preferred for foraging. Grass 
biomass was about two-thirds less in areas of bluegrass with sagebrush than without. Thus, feeding elk apparently selected areas containing the most available forage.

Kev Words: TERRESTRIAL ECOLOGY - ALE Reserve, ecological relations, elk, food and feeding, habitat use

\section{M-18}

McCorquodale,S. M., L. L. Eberhardt, and L. E. Eberhardt. 1988. "Dynamics of a Colonizing Elk Population." J. Wildl. Manage, 52:309-313.

Abstract: The estimated rate of increase (r) for elk naturally colonizing an area in the shrub-steppe region of eastern Washington (the ALE Reserve) was 0.20 for $1975-86,2$ to 13 years after colonization. From 1982 to 1986, r was 0.30 and survival of all age classes was high. From 1982 to 1986, 0.76 calves were weaned per female, if 2-year-olds were included, or 0.91 calves per female, if 2-year-olds were excluded. Age-specific pregnancy and survival rates were combined in a model to evaluate the effect of various parameters on rates of increase. The observed high rate of increase was probably caused by high survival the first year, and substantial reproduction from 2-year-old female elk.

Key Words: TERRESTRIAL ECOLOGY - ALE Reserve, population density, elk, population increase, reproduction, survival

\section{M-19}

McCorquodale,S. M., L. E. Eberhardt, and S. E. Petron. 1988. "Helicopter Immobilization Of Elk in Southcentral Washington." Northwest Sci, 62:49-52.

Abstract: To evaluate various drugs used to immobilize elk from helicopters, 38 elk were darted on the ALE Reserve from 1983 to 1987 . The primary immobilants were either succinylcholine (most commonly unsuccessful), etorphine hydrochloride, or xylazine hydrochloride. Induction times were similar in elk darted with xylazine and etorphine, and shortest in elk darted with succinylcholine. Use of xylazine and yohimbine (to reverse xylazine immobilization) provided an efficient, cost-effectivealternative to etorphine, diprenorphine immobilization and reversal in elk while increasing handler safety. Etorphine appeared the best immobilant when extended pain-producing procedures (such as telemetry implantation) were planned because it induced the longest and deepest anesthesia. When there is potential to lose contact with an animal, succinylcholine may be preferred because it provides rapid, spontaneous recovery.

Key Words: TERRESTRIAL ECOLOGY - capture technique, elk, immobilization

M-20

McCorquodale,S. M., K. J. Raedeke, and R. D. Tabor. 1986. "Elk Habitat Use Patterns in the Shrub-Steppe of Washington." J. Wildl. Manage. 50:664-669.

Abstract: Habitat use by elk was studied in the shrub-steppe of the ALE Reserve from March through October 1983 and 1984. Four male and four female elk were located through radiocollars 782 times. The animals preferred low elevation topographic zones. Female elk selected low elevation sagebrush areas during spring, late summer, and fall and moved to riparian areas during the calving period and later summer months. Sagebrush stands were important bedding areas, particularly during late summer. Male elk selected sagebrush during spring, summer, and fall. Lactating female elk needed to associate with natural springs, but bull elk were less constrained by the availability of free water. The animals were active nocturnally. In the absence of extensive cover, elk decreased thermoregulation costs by bedding in sagebrush stands and by limiting diurnal foraging. The behavior of the ALE population suggests that elk can survive with limited cover when they are infrequently disturbed and have adequate forage.

Kev Words: TERRESTRIAL ECOLOGY - ALE Reserve, ecological relations, elk, habitat use, reproduction

\section{M-21}

McGhan, V. L., P. J. Mitchell, and R. S. Argo. 1985. Hanford Wells. PNL-5397, Pacific Northwest Laboratory, Richland, Washington. 304 p. 
Contents: A list of over 2,900 wells on or near the Hanford Site was compiled. Further, information on wells that existed before construction of the "Hanford Works" (220 wells, mostly hand-dug) to the present time (mostly cased wells) was updated. Condensed and tabulated information on the location, construction, and completion dates of these wells was listed. Data on lithologic logs and ground-water contamination were not included. The list is incomplete because construction of new wells and modification of existing wells is continually under way. However, this report gives the most complete description of wells at Hanford.

Key Words: HANFORD SITE - monitoring wells, potable wells, wells, well construction

\section{M-22}

McLaughlin, T. J., J. M. V. Carlile, K. H. Cramer, K. A. Hawley, D. A. Lamar, D. R. Sherwood, and P. J. Krupin. 1987. "Preliminary Assessment of Mixed Hazardous and RadioactiveInactive Waste Sites at Hanford." In Waste Manaeement '87. Proceedings of the Svmnosium on Waste Management. Vol3 Low-Level Wastes, ed. R. G. Post, pp. 723-728. University of Arizona Press, Tucson, Arizona.

Abstract: In July 1986, the DOE, Richland Operations Office and PNL completed a preliminary assessment of 337 inactive waste sites used between 1943 and 1980 to dispose liquid and solid wastes to the soil on the Hanford Site. This preliminary study was the first phase of DOE-RL's Comprehensive Environmental Response, Compensation, and Liability Act (CERCLA) program, and will be used to determine sites for further investigation and possible remediation. This report is not yet final, and some results could change. There was little evidence to indicate that any of the 337 engineered wastedisposal structures pose a risk to public health. However, preliminary assessment showed that 62 sites should be characterized, and an additional 158 inactive sites should be investigated.

\section{Kev Words: EFFLUENTS AND WASTES -} Hanford Site, hazardous materials, radioactive waste, radioactive waste management, regulatory compliance, remedial plans, waste disposal sites
McShane, M. C., and R. H. Sauer. 1985. "Comparison of Experimental Fall Burning and Clipping on Bluebunch Wheatgrass." Northwest_Sci. 59:313-318.

Abstract: The effects of autumn burning and clipping of bluebunch wheatgrass on production the next spring was examined on the ALE Reserve, Hanford. Clipping and burning shortened leaf lengths during the first growing season after treatment. Shoot biomass and seedhead formation were both reduced by clipping but not by burning. No measurable differences were detected between plants treated individually and collectively (in a $3.14 \mathrm{~m}^{2}$ study area), suggesting that bluebunch wheatgrass was not greatly influenced by burning or clipping neighboring plants. Differences in productivity between clipping and burning were likely due to differences in microclimate.

Kev Words: TERRESTRIALECOLOGY - bluebunch wheatgrass, effect of burning, effect of clipping, plant production

\section{M-24}

Meinhardt, C. C., D. L. Flyckt, R. M. Wirsing, and J. A. Winterhalder. 1987. "Alternatives to Disposal of Hanford Site Liquid Effluents to the Soil Column." In Waste Management '87, Proceedings of the Svmposium on Waste Management. Vol. 1 General Interest, ed. R. G. Post, pp. 357-363. University of Arizona Press, Tucson, Arizona.

Abstract: A feasibility study was conducted to identify and evaluate different waste disposal systems for liquid effluents now discharged to the soil on the Hanford Site. Alternative systems were selected for 28 effluent streams, based on available technology and its ability to either eliminate the contaminated effluent or reduce contaminant levels to meet specified effluent disposal criteria and standards from DOE orders and environmental statutes. Technically feasible alternatives for disposing of Hanford's waste are available. The main effect from current disposal practices is the accumulation of radioactivity in the soil and unconfined aquifer. The potential for significant nonoccupational dose to humans results only from the assumption that, at some unspecified future time, government control of the Hanford Site ceases and is followed by extensive human habitation. 
Kev Words: EFFLUENTS AND WASTES - alternatives assessment, Hanford Site, radioactive waste, remedial studies, waste disposal/treatment

M-25

Miller, M. L., J. J. Fix, and P. E. Bramson. 1980. "Lognormal Analysis of Naturally Occurring Radionuclides in Soil and Vegetation of the Hanford Area." In Natural Radiation of the Environment III, eds. T. F. Gesell and W.M. Lowder, pp. 826-831 (CONF-780422, Vol. 1). National Technical Information Service, Springfield, Virginia.

Abstract: Concentrations of naturally occurring radionuclides in soil and vegetation of the Hanford area were analyzed by lognormal probability plotting. Such plots are useful for cataloging large amounts of data and providing a first approximation of the variability or similarity of the data. When data from the years 1971 through 1976 were analyzed, the linearity of the plots indicated that the radionuclide concentrationswere lognormally distributed. The plots were used to estimate the range in concentrations of various radionuclides. The absorbing dose rate received at $1 \mathrm{~m}$ above the ground from naturally occurring ${ }^{40} \mathrm{~K},{ }^{232} \mathrm{Th}$ plus daughters, and ${ }^{238} \mathrm{U}$ plus daughters in the underlying soil was calculated to be about $38 \mathrm{mrads} / \mathrm{yr}$.

Key Words: RADIOACTIVITY - background (natural) radiation, dose from natural radiation, radiation data, surface monitoring, surface soil

\section{M-26}

Miller, R. L., and R. K. Wahlen. 1987. Estimates of Solid Waste Buried in 100 Area Burial Grounds. WHC-EP-0087, Westinghouse Hanford Company, Richland, Washington. 42 p., App. A through E.

Abstract: Previous estimates of radionuclide inventory and hazardous materials were based on extrapolations from limited historical burial records. Estimates in this report were based on the review of historical documents, on reconstruction of operating practices, and on the experiences of knowledgeable individuals involved in waste disposal when the reactors were operating. The major radioactive wastes in the burial grounds were 375 tons of aluminum spacers, 1,103 tons of lead-cadmium pieces, boron splines ( 62.5 tons aluminum and 8.5 tons boron), carbon materials (2,300 lb graphite and $13,200 \mathrm{lb}$ desiccant), 266 tons of aluminum process tubes, and 259 tons of lead. Miscellaneous wastes totalled 159.2 tons and included gunbarrels, thimbles, control rods, nozzles, pigtails, and cadmium sheets.

Radionuclide inventories were calculated from the volume of each type of waste. Major radionuclides were tritium $\left({ }^{3} \mathrm{H}\right),{ }^{14} \mathrm{C},{ }^{60} \mathrm{Co},{ }^{63} \mathrm{Ni},{ }^{90} \mathrm{Sr},{ }^{137} \mathrm{Cs}$, and ${ }^{152} \mathrm{Eu}$ and ${ }^{154} \mathrm{Eu}$.

\section{Kev Words: EFFLUENTS AND WASTES -}

hazardous materials, radioactivesolid waste, radioactive waste management, radionuclide inventory, waste disposal/treatment, 100 Area Burial Grounds

\section{M-28}

Mishima, J., S. L. Sutter, K. A. Hawley, C. E. Jenkins, and B. A. Napier. 1986. Potential Radiological Impacts of Unper-Bound Operational Accigents During Prooosed Waste Disnosal Alternatives for Hanford Defense Waste. PNL-5356, Pacific Northwest Laboratory, Richland, Washington. Irregular pages.

Abstract: Three alternativeswere evaluated for disposal of defense wastes at Hanford. The wastes include existing tank waste, future tank waste, cesium and strontium capsules, TRU-contaminated soil, pre1970 buried TRU solids, and retrievably stored and newly generated TRU solid waste. The alternatives were geologic disposal, in-place stabilization and disposal, and reference disposal. In all three alternatives, the postulated event with the greatest radiologic impact was an explosion of a mixture of ferri/cyanide precipitates during the mechanical retrieval or microwave drying of salt cake in single-shell waste tanks. The anticipated downwind (70-year dose commitment) to the maximally exposed individual was $3 \mathrm{rem}$, and the total population dose was 7000 man-rem. The same individual would receive 7 rem from natural background radiation during this period, and the same population would receive $3,000,000$ man-rem. Radiological impacts to the public from all other postulated accidents would be less; furthermore, the radiological impact resulting from the "maximum" postulated accident would be less than half that from natural background radiation dose. Because this was a postulated accident, operational 
accidents in general should not be an important discrimination among alternatives.

Kev Words: HANFORD SITE - alternatives assessment, environmental assessment, high-level radioactive waste, radiation dose assessment, waste disposal alternatives

\section{M-28}

Mitchell, D. E. 1987. Hanford Waste Vitrification Plant Preliminary Descriotion of Waste Form and Canister. WHC-EP-0008, Westinghouse Hanford Company, Richland, Washington. 37 p., App. A through $\mathrm{C}$.

Contents: A waste acceptance process developed by the DOE's Office of Civilian Waste Management enables producers of high-level defense wastes to develop requirements for accepting candidate geologic repositories. The process requires three documents: a Description of Waste Form and Canister, a Waste Compliance Plan, and a Waste Qualification Report. This document focuses on the disposal of neutralized current acid wastes at the Hanford Waste Vitrification Plant. It is limited to a description of the physical and chemical characteristics of the expected high-level waste, covering three major areas: waste form and characteristics, canister characteristics, and canistered waste form characteristics. The information will be used by the candidate geologic repository projects as the basis for preliminary repository design activities and waste form testing. Periodic revisions are expected.

Kev Words: EFFLUENTS AND WASTES - waste vitrification plant, high-level waste, radioactive solid waste, remedial plans, waste disposal/treatment

\section{M-29}

Mitchell, P. J. 1987. "Ground-Water Flow Modeling at a Hazardous Waste Site for Regulatory Compliance." In Proceedings. Solving Ground-Water Problems with Models, pp. 1434-1452. National Water Well Association, Dublin, Ohio.

Abstract: A model was developed for unconfined ground-water flow beneath a hazardous waste facility near the Columbia River on the Hanford Site (no location specified). Characterization was complicated by fluctuations in the water table of several feet per day near the facility caused by discharges upstream at Priest Rapids Dam. The two-dimensional, finite difference model was calibrated with 6 months of continuous measurements from three wells and continuous river stage data. Responses modeled for well locations matched field-recorded groundwater levels and hydraulic gradients near the facility. Simulations of the unconfined aquifer were used to estimate probable paths for any transport from the facility. This flow model and a planned solute transport model will limit the number of monitoring wells required later and assist additional site characterization.

\section{Kev Words: GEOLOGY AND HYDROLOGY -} computer modeling, Hanford Reach, solute transport model, unconfined aquifer

\section{M-30}

Mitchell, P. J., R. S. Argo, S. L. Bradymire, and C. A. Newbill. 1985. Hanford Ground-Water Data Base Management Guide and User's Manual. PNL5486, Pacific Northwest Laboratory, Richland, Washington. 67 p., App. A through C.

Contents: A working document is provided on the computerized Hanford Ground-Water Data Base (GWDB). The GWDB provides rapid access to data that are routinely collected from ground-water monitoring wells on the Hanford Site. Data include water levels, sample analyses, geologic descriptions, and well construction information for over 3000 existing wells. These data are used to monitor water quality and to evaluate ground-water flow and pollution transport. Instructions are given for maintaining the data base on the Digital Equipment Corporation PDP 11/70 Computer using the CIRMIS software developed at PNL. Maintenance activities include inserting, modifying, and deleting data, making backup copies of the data base, and generating tables for annual monitoring reports.

Kev Words: HANFORD SITE - ground water, ground-water data base, ground-water quality, monitoring wells, unconfined aquifer, wells, well construction 
Mitchell, P. J., and M. D. Freshley. 1987. "GroundWater Monitoring and Modeling at the Hanford Site." In Waste Management '87. Proceedings of the Svmoosium on Waste Management 1987. Vol. 1 General Interest, ed. R. G. Post, pp. 351-355. University of Arizona Press, Tucson, Arizona.

Abstract: The ground-water monitoring program at Hanford continually evolves in response to changes in onsite operations, ground-water flow system, movement of constituents in the aquifers, and regulatory requirements. Sampling and analysis of ground water, along with ground-water flow and solute transport modeling, are used to evaluate the movement and distribution of both radionuclides and hazardous chemicals in the unconfined aquifer. Evaluation of modeling results, modeling, and information on waste management practices are combined to continually improve the network of ground-water monitoring wells.

Kev Words: HANFORD SITE - environmental monitoring, ground water, ground water modeling, monitoring program, monitoring wells, waste disposal sites

\section{M-32}

Montgomery,J. C., and C. D. Becker. 1980. "Gas Bubble Disease in Smallmouth Bass and Northern Squawfish from the Snake and Columbia Rivers." Tran. Am. Fish. Soc. 109:734-736.

Abstract: Two species of resident fish were collected by angling from the lower Snake and mid-Columbia rivers during spring freshets of 1975 and 1976. They were inspected for external symptoms of gas bubble disease, which results from supersaturation of river water with dissolved gases at hydroelectric dams. Emboli were found on $72 \%$ of 179 smallmouth bass and $84 \%$ of 85 northern squawfish, in correlation with total gas supersaturations in excess of $115 \%$.

Key Words: AQUATIC ECOLOGY - effects of air supersaturation, Hanford Reach, northern squawfish, smallmouth bass
Montgomery,J. C., D. A. Fickeisen, and C. D. Becker. 1980. "Factors Influencing Smallmouth Bass Production in the Hanford Area, Columbia River." Northwest Sci, 54:296-305.

Abstract: Adult smallmouth bass were monitored in relation to water levels in the Hanford Reach. Movement was influenced by water level fluctuations, water depth, current, and forage organisms. Bass traveled as far as $61 \mathrm{~km}$ with radio transmitters and $63 \mathrm{~km}$ with dart tags. Bass spawned from April through June in warmed sloughs and backwater areas. Spawning in White Bluffs, Hanford, and F Area sloughs was affected by high flows, which flooded nests with cool water and caused other disturbances. Spawning success was poor in 1976, a high-water year, and good in 1977, a low-water year. Juvenile bass were lost by entrapment, predation, thermal and oxygen stress, and desiccation in pools caused by water level fluctuations.

Kev Words: AQUATICECOLOGY - fish behavior, fish movement, fish spawning, habitat use, Hanford Reach, smallmouth bass, effect of water level fluctuations

\section{M-34}

Morgan, L. G., W. W. Schultz, M. R. Adams, and K. W. Owens. 1988. Summary of Single-Shell Tank Waste Characterization: 1985 to 1987 . WHC-EP0075, Westinghouse Hanford Company, Richland, Washington. Irregular pages, App. A through X.

Contents: A multidisciplinary team was assembled in early FY 1985 to address issues and problems associated with characterization of single-shell tank (SST) wastes on the Hanford Site. The team addressed both the requirements of characterizing the wastes and the most effective methods that might be used. Team efforts continued through FY 1985,1986, and 1987, and are expected to continue until characterization is satisfactorily resolved. This document summarizes the initial characterization strategy, describes the team's activities, presents significant results of these activities, and identifies changes in characterization strategy. The team documented statistical needs to estimate the inventory by sampling the contents of 
the SST, evaluated model validity and model predictions of SST contents, defined statistical needs to calibrate and verify models, assessed technical requirements of characterization, defined performance assessment needs to characterize the wastes, and developed a plan to characterize the wastes that requires further information to produce a final strategy.

Kev Words: EFFLUENTS AND WASTES - highlevel waste, remedial assessment, single-shell tanks, waste characterization, 200 Areas

\section{M-35}

Murphy, P. J., and G. D. Johnpeer. 1981. An Assessment of Geothermal Resource Potential Pasco Basin and Vicinitv. Washington. RHO-BW-CR-128 P, Rockwell Hanford Operations, Richland, Washington. $12 \mathrm{p}$.

Abstract: The geothermal resource potential of the Pasco Basin and vicinity was limited to the potential occurrence of low-temperature (less than $90^{\circ} \mathrm{C}$ ) geothermal systems. High and intermediate temperature systems were not believed to exist because a sufficient heat source was apparently lacking. Potential low-temperature systems could be hydrothermal convection systems in which meteoric water circulating in the normal heat flow of the region is heated to about $100^{\circ} \mathrm{C}$ at depths of about $3 \mathrm{~km}$. Faults associated with major anticlines are potential conduits for transporting this fluid back toward the surface. Should zones of high vertical permeability associated with these faults extend to depths of 2 to 3 $\mathrm{km}$, fluid migrating rapidly upward could be stored in interbed and interflow zones within the confined aquifer.

Kev Words: GEOLOGY AND HYDROLOGY confined aquifer, geothermal potential, Pasco Basin, subsurface characteristics

\section{M-36}

Murthy, K. S., L. A. Stout, B. A. Napier, A. E. Reisenauer, and D. K. Landstrom. 1983. Assessment of Single-Shell Tank Residual Liauid Issues at Hanford Site, Washington. PNL-4688, Pacific Northwest Laboratory, Richland, Washington. Irregular pages.
Contents: This report assesses the overall implications of jet pumping interstitial liquids from singleshell storage tanks at Hanford to minimize leaks to the ground. The pumping program currently in process involves removing liquids from 89 of 149 single-shell tanks, reducing their volume by evaporation, and transferring the residue to double-shell tanks. This report estimates radiation doses to the public and workers under four options: 1) terminating pumping immediately, 2) pumping to a 100,000 gal limit per tank, 3) pumping to a 50,000-gal limit per tank, and 4) pumping to the maximum lowest limit of 30,000 gal. The cost effectiveness of various levels of pumping in minimizing health and safety risks is also presented.

Kev Words: EFFLUENTS AND WASTES - highlevel waste, remedial assessment, single-shell tanks, waste disposal/treatment, waste retrieval, 200 Areas

\section{M-37}

Myers, C. W. and S. M. Price, eds. 1981. Subsurface Geology of the Cold Creek Svncline. RHOBWI-ST-14, Rockwell Hanford Operations, Richland, Washington. Irregular pages, App. A through F.

Abstract: Bedrock beneath the Hanford Site is being evaluated by BWIP for possible use as a geological repository for nuclear wastes. Initial studies showed that the central Hanford Site contains basalt flows with thick, dense interiors that have low porosities and permeabilities. Furthermore, within the Cold Creek Valley (CCV) syncline, these flows appear to be nearly flat, and lie across areas in excess of tens of square kilometers. The Umtanum flow, which lies 900 to $1,150 \mathrm{~m}$ below the surface, is currently the leading candidate for the repository. This report gives current knowledge of stratigraphic, lithologic, and structural factors that relate to suitability of the Umtanum flow within the CCV syncline for a repository.

The CCV syncline lies between the Umtanum Ridge-Gable Mt. anticlinal structure on the north and the Yakima Ridge and Rattlesnake Mt. anticlinal structures on the south. Two depressions occur along the troughline: the Cold Creek depression, within the area of the proposed RRL, and the Wye Barricade depression, about $25 \mathrm{~km}$ to the east. The $\mathrm{CCV}$ syncline plunges and dies out to the east near the Wye Barricade depression. 
The western part of the CCV syncline is presently interpreted as consisting of five, large, relatively intact volumes of bedrock with boundaries defined by first-order anticlines or other known or inferred structures. The interior of the RRL lies within one of these large, relatively intact bedrock volumes. The bedrock of the CCV syncline consists of flows belonging to three formations of the Columbia River Basalt group: 1) Grande Ronde Basalt, 2) Wampum Basalt, and 3) Saddle Mt. Basalt. The flows average $35 \mathrm{~m}$ in thickness, and with a range of 4 to $150 \mathrm{~m}$. The basalt is interbedded with sediments of the Ellensburg Formation and is overlain by up to $220 \mathrm{~m}$ of the fluvial-lacustrineMiocene-Pliocene Ringold Flood Formation and catastrophic flood deposits of the Pleistocene Hanford formation.

Overall, the central and eastern parts of the CCV depression within the RRL seem to contain a uniformly thick part of the Umtanum flow and is free of potentially adverse bedrock structures relative to other parts of the area. The structureat top of the basalt and the structure at deeper layers in this area are interpreted as being nearly flat, with gentle dips toward the trough of the CCV syncline and with a slight westward extension of dip toward the deepest part of the CCV depression. Additional drilling and geophysical work will be designed to detect and characterize subtle structures and to test interpretations.

Kev Words: GEOLOGY AND HYDROLOGY basalt formations, Cold Creek Valley syncline, reference repository location (RRL), seismology, stratigraphy, Umtanum flow

\section{N-1}

Napier, B. A. 1981. Standardized Input for Hanford Environmental Impact Statements - Part I. PNL3509, PT1, Pacific Northwest Laboratory, Richland, Washington. 34 p., App. A.

Contents: Current methods in use at Hanford were described for calculating radiation doses to the public from routine and accidental releases of radionuclides to the environment. It is intended as an overview and a starting point for persons preparing EIS's for locations on the Hanford Site. Less detailed information is given on calculating ground-water transport pathways because such calculationsare highly facility and site specific.
Kev Words: RADIOACTIVITY - exposure pathways, Hanford Site releases, radiation assessment, radiation dose estimates

\section{N-2}

Napier, B. A 1982. AMethod for Determining "Allowable Residual Contamination Levels" of Radionuclide Mixtures in Soils. PNL-3852, Pacific Northwest Laboratory, Richland, Washington. 58 p.

Abstract: The amount of radioactive contamination that may remain at a site is important for planning remedial action. A method was developed at PNL, called the "allowable residual contamination level" (ARCL), to predict an acceptable amount of residual radiation. The ARCL method depends on the imposed radiation dose limit, the physical and environmental characteristics of the site, and the time when exposure to the wastes is expected. Application and modification of the ARCL require appropriate models of transport and fate of radionuclides, and consideration of natural and engineered barriers. The basic steps in generating an ARCL are listed.

Examples are calculated for several waste forms and waste site types to demonstrate the technique.

Kev Words: EFFLUENTS AND WASTE - allowable residual contamination level, Hanford Site, remedial studies, surface soil, radioactive waste management

\section{N-3}

Napier, B. A., W. E. Kennedy, and J. K. Soldat. 1980. PABLM - A Comvuter Program to Calculate Accumulated Radiation Doses from Radionuclides in the Environment. PNL-3209, Pacific Northwest Laboratory, Richland, Washington. 5 p, App. A through G.

Abstract: A computer program, PABLM, was written to aid calculation of accumulated radiation doses to man from radionuclidesin food products (internal doses) and in the environment (external doses). This report describes the mathematical models and calculations needed to run the program. Up to 19 ingestion pathways (or food products) may be selected with corresponding consumption rates, growing periods, and air or water concentrationsand deposition rates. Four external pathways may also be 
selected. For all pathways chosen, radionuclides may be deposited in soil over the life of the emitting facility. After the facility is shut down, radionuclides remain in the soil and are assumed to be removed only by radioactive decay. The type and amount of crops grown nearby determines terrestrial pathways to be considered. Release of liquid effluents determines which, if any, aquatic pathways to use. Dose factors for swimmers are calculated from the concentration of radionuclidesin water, assuming an infinite medium with respect to the range of emitted radiations. Radiation dose for boaters is assumed half that of swimmers. PABLM can be used to calculate accumulated dose to 23 body organs or tissues for any one or combination of radionuclides. Up to five organs and 100 radionuclides may be selected in a mixture. Output consists of radiation dose summaries to all chosen organs listed by exposure pathway and by radionuclide. An option exists to list dose contributions by radionuclide in each pathway.

Kev Words: RADIOACTIVITY - computer modeling, exposure pathways, PABLM model, radiation assessment, radiation dose estimates

\section{N-4}

Napier, B. A., R. A. Peloquin, W. E. Kennedy, Jr., and S. M. Neuder. 1984. Intruder Dose Pathway Analvsis for the Onsite Disposal of Radioactive Wastes: The ONSITE/MAXI Computer Program. (NUREG/CR-3620 (PNL-4054), U.S. Nuclear Regulatory Commission, Washington, D.C. Irregular pages, App. A through D.

Contents: Assessing potential risks from onsite burial of radioactive wastes is uncertain. Therefore, the NRC amended its regulations to reduce potential hazards to the public. Licensees must now apply for approval of proposed procedures to be used for onsite disposal pursuant to 10 CFR 20.302. Requests are reviewed by the NRC on a case-by-case basis. Technical reviews require modeling of potential exposure pathways and radiation doses. This report summarizes efforts at PNL to develop humanintrusion scenarios and to modify a MAXI computer program for potential use in NRC site-specific considerations. The ONSITE/MAXI computer program is written for two audiences, one concerned with mathematical models and computer algorithms, the other with applying the program and its scenarios to specific cases. Five sample programs are presented, summaries of input and output for each sample are included, and verification of correct operation with hand calculations is discussed. Appendices provide information to effectively use the program

Kev Words: RADIOACTIVITY - computer modeling, NRC nuclear waste sites, ONSITE/MAXI model, radiation assessment, radiation dose estimates

\section{N-5}

Napier, B. A., R. A. Peloquin, and D. L. Strenge. 1986. DITTY - A Comouter Program for Calculating Pooulation Dose Integrated Over Ten Thousand Years. PNL-4456, Pacific Northwest Laboratory, Richland. Washington. 25 p., App. A through $\mathrm{H}$.

Contents: The computer program DITTY (Dose Integrated Over Ten Thousand Years) was developed to estimate the collective dose from ground-water pathways that might result at long-term, nuclear waste disposal sites. DITTY estimates the time interval for collective dose from time-variant releases of radionuclides to surface water, wells, or the atmosphere. This document describes the mathematical models, program designs, data file requirements, input preparation, output interpretations, sample problems, and program-generated diagnostic messages associated with DITTY.

Kev Words: RADIOACTIVITY - computer modeling, DITTY model, exposure pathways, offsite dose estimates, radiation assessment, radiation dose estimates

\section{N-6}

Napier, B. A., R. L. Roswell, W. E. Kennedy, Jr., and D. L. Strenge. 1980. ARRRG and FOOD -

Computer Programs for Calculating:Radiation Dose to Man from Radionuclides in the Environment. PNL-3180, Pacific Northwest Laboratory, Richland, Washington. 6 p., App. A through T.

Contents: The ARRRG and FOOD programs were written to aid calculation of internal and external (respectively) radiation doses to man from environmental sources. The programs are recent versions of 
FORTRAN that are easier to use and follow than older codes. ARRRG addresses aquatic pathways carrying radionuclidesto man, and can compute doses from fish, other aquatic animals or plants, drinking water, swimming, boating, or shorelines. FOOD addresses terrestrial pathways leading to man, and can compute doses from 14 types of food and external radiation. Both programs can calculate 1year doses and dose commitments from any one or combinations of radionuclides. As many as 5 of 24 possible organs or tissues, and mixtures of up to 100 radionuclides may be selected. Computer output consists of radiation dose and dose commitment summaries to all organs listed, by exposure pathway and by radionuclide. Options exist for complete listing of dose contributions from each radionuclide for each pathway.

Kev Words: RADIOACTIVITY - ARRRG model, computer modeling, exposure pathways, FOCD model, radiation assessment, radiation dose estimates

\section{N-7}

Nealy, S. M., and E. B. Liebow (eds.). 1988. Assessing Social and Economic Effects of Perceived Risk: Workshon Summary. BWIP Repository Project, Draft. PNL-6515 (BHARC-800/88/005), Pacific Northwest Laboratory, Richland, Washington. Irregular pages.

Abstract: A workshop was held in Seattle (August 6, 1987) to discuss the social and economic effects of risk perceptions related to permanent underground storage of radioactive wastes. Assembled experts generally agreed that, first, perception of risk from a repository (such as BWIP) would cause socioeconomic impacts and, second, that a meaningful role for those who bear the risk offers the best hope of ameliorating perceived problems.

Risk estimates are subject to disagreement, largely because: 1) there are never enough empirical data to be definite, 2) models used in risk analysis can bias results, 3) estimates are averages and do not necessarily apply to the case at hand, 4) large uncertainties are associated with the estimates, and 5) new technologies lack a base of operating experience. The terms "calculated risk" or "risk based on probability estimates" should be used in place of real risk, because real risk cannot be defined. The role of the public in assessing, managing, and deciding on risk should be reconsidered. Mitigation and compensation are central to resolving conflicts. Experts and laypersons view risk in different ways, leading to higher levels of public concern than most experts feel are justified.

Kev Words: SOCIOECONOMIC - BWIP, risk perception

\section{N-8}

Neitzel, D. A., C. D. Becker, C. S. Abernethy, D. W. Carlile, and E. W. Lusty. 1984. Laboratorv Simulations of Chinook Salmon Redd Dewatering: An Assessment of Potential Impacts at Vernita Bar. Prepared by Pacific Northwest Laboratory for The Public Utility District of Grant County, Ephrata, Washington. 54 p., App. A.

Abstract: Laboratory tests were conducted to simulate dewatering of chinook salmon redds (nests in gravel) at Vernita Bar, a potential consequence of changes in river flow at and above Priest Rapids Dam. Data from these and other dewatering experiments at PNL indicated that: 1) Bank-stored water mitigates effects of daily dewatering on survival of chinook eggs and fry in redds. 2) Weather extremes during exposure to the atmosphere under dewatering conditions at Vernita Bar will not damage chinook eggs or fry in redds. 3) Limited dewatering during daily peaking operation of Priest Rapids Dam will not damage chinook eggs in redds. 4) Extended dewatering of Vernita Bar that exhausts bank-stored water may cause losses of eggs and fry. 5) Use of aboveground watering systems (sprinklers)at Vemita Bar during extended dewatering may need to provide volumes approaching bank-stored flow to provide protection. 6) Assessment of effects must include estimates of varying tolerance to environmental stress resulting from parent stocks, and estimates of natural mortalities from movement of fry within redds.

Kev Words: AQUATICECOLOGY - chinook salmon, effect of redd dewatering, fish reproduction, Vemita Bar

\section{N-9}

Neitzel, D. A., T. L. Page, R. H. Gray, and D. D. Dauble. 1982. "Once-through Cooling on the 
Columbia River - the Best Available Technology?" Environ. Impact Assess. Rev, 3:43-58.

Abstract: The HGP uses once-through passage of Columbia River water to cool its condensers. The water is heated $19^{\prime}$ to $24^{\circ} \mathrm{C}$, depending on pumping mode, and discharged at mid-river through a fourport diffusor. Because of its age, HGP is exempt from changing to closed cycle cooling. However, HGP's thermal discharge does not always comply with state standards, which mean an alternate cooling system must be installed. A 316(a) Demonstration, prepared in accordance with EPA's Technical Guidance Manual, examined potential impacts on six biotic categories: phytoplankton,zoo- and meroplankton, habitat formers, macroinvertebrates and shellfish, fish, and vertebrate wildlife. No significant impact was shown to exist. Once-through cooling at HGP appeared to be environmentally acceptable.

Kev Words: HANFORD SITE - cooling water discharge, environmental assessment, Hanford Reach, HGP, HGP operation, 316(a) Demonstration

\section{$\mathrm{N}-10$}

Neitzel, D. A., T. L. Page, and R. W. Hanf, Jr. 1982. "Mid-Columbia River Microflora." L, Freshwater Ecol, 1:495-506.

Abstract: Studies on microflora in the Hanford Reach from 1973 through 1980 included estimates for relative abundance, density, chlorophyl a, carbon uptake, and organic matter. Microfloral communities consisted largely of diatoms. While species composition changed throughout the year, generally one or two taxa dominated at any one time. Productivity appeared to reach maximum in summer and minimum in winter, but monthly samples showed a fall peak also. Benthic microflora may have been more productive than phytoplanktonic microflora. Estimates of phytoplankton density have apparently been increasing since 1949.

Kev Words: AQUATIC ECOLOGY - Hanford Reach, periphyton, phytoplankton, primary production, species composition

\section{N-11}

Neitzel, D. A., T. L. Page, and R. H. Hanf, Jr. 1982. "Mid-ColumbiaRiver Zooplankton." Northwest Sci. 57:112-118.

Abstract: Zooplankton were collected from two locations (HGP and WNP-2) in the Hanford Reach from June 1973 through March 1980. Crustaceanzooplankton, consisting of 12 species, numerically dominated most samples. Bosmina, Diaptomus, and Cyclops were the dominant genera. Fifty-eight taxa were identified. Zooplankton densities generally followed a trend of winter minimum and late-spring, early summer maximum.

Kev Words: AQUATICECOLOGY - Hanford Reach, relative abundance, species composition, zooplankton

\section{$\mathrm{N}-12$}

Neitzel, D. A., T. M. Poston, C. S. Abemethy, M. T. McLane, T. L. Page, and D. W. Carlile. 1984. Laboratorv Simulated Passage of Four Species of Fish Through the N Reactor Plume in Spring During Single-Purpose Mode of Operation. WHC-EP-0177, Prepared by Pacific Northwest Laboratory for UNC Nuclear Industries, Inc. , Richland, Washington. 59 p., App. A and B.

Abstract: Laboratory tests with four Representative Important Species (RIS) of fish simulated potential exposure to elevated plume temperatures under conditions representing N Reactor in single-purpose operation during spring. The RIS were chinook salmon, coho salmon, steelhead, and northern squawfish. Evaluation was based on direct mortality (lethal temperature) and indirect mortality (predation, disease). Results indicated that: 1) no potentially lethal conditions existed at flows of $54,000 \mathrm{cfs}$ or above, 2) thermal tolerance varied among species and was least for chinook salmon, 3) the maximum width of the plume that might cause mortality was $60 \mathrm{ft}$ and occurred at 36,000 cfs flow, 4) indirect mortalities from disease would not be expected for fish surviving plume passage, and 5) indirect mortality from predation would not be expected at flows above 45,000 cfs. 
Kev Words: HANFORD SITE - cooling water discharge, environmental assessment, $\mathrm{N}$ Reactor, $\mathrm{N}$ Reactoroperation, representative important species, thermal plume

\section{$\mathrm{N}-13$}

Neitzel, D. A., T. M. Poston, C. S. Abernethy, T. L. Page, and D. W. Carlile. 1984. Laboratory Simulation of Late-Summer Juvenile Chinook Salmon Passage Through N Reactor Thermal Plume During, Single-Purnose Mode of Operation. WHC-EP-0176, Prepared by Pacific Northwest Laboratory for UNC Nuclear Industries, Inc., Richland, Washington. 44 p., App. A through D.

Abstract: Laboratory tests were used to simulate potential exposure of juvenile chinook salmon to elevated temperatures that represented conditions in the discharge plume of $\mathrm{N}$ Reactor during late summer when the facility was in single-purposeoperation. Evaluation was based on direct mortality (lethal temperature) and indirect mortality (predation, disease). Test data indicated: 1) potentially lethal temperatures occurred in the discharge plume during late summer, 2) the width of the plume with potentially lethal conditions depended on river flow, 3) lethal conditions were not expected when river flows exceeded $144,000 \mathrm{cfs}, 4)$ the maximum width within the plume that might cause mortality was $120 \mathrm{ft}$ and occurred at 36,000 cfs flow, and 5) indirect mortalities would not be expected for fish surviving plume passage.

Kev Words: HANFORDSITE - cooling water discharge, environmental assessment, $\mathrm{N}$ Reactor, $\mathrm{N}$ Reactor operation, thermal plume

\section{N-14}

Neitzel, D. A., T. M. Poston, T. L. Page, and C. S. Abernethy. 1986. "Laboratory Simulation of Fish Passage Through a Heated Water Discharge," In Aauatic Toxicology and Environmental Fate: Ninth Volume, eds. T.M. Poston and R. Purdy, pp. 122134. ASTM Special Technical Publication No. 921, American Society of Testing and Materials, Philadelphia.
Abstract: Laboratory simulation of Representative Important Species of fish passing through the $\mathrm{N}$ Reactor plume provides better data for assessment of thermal effects than data available in the literature, and is more specific to assessment criteria than data collected from field studies. The test organisms were juvenile chinook salmon, coho salmon, steelhead, and northern squawfish. Simulations were conducted in aquaria plumbed to receive and dischargeheated water. The aquaria simulated exposures of fish entering a thermal plume while passing downstream. Fish that survived passage were exposed to predators and disease organisms to check the possibility of indirect mortality. Fish survived when the initial increase in water temperature was $16^{\circ} \mathrm{C}$ above the ambient river temperature. The highest ambient temperature tested was $18.3^{\circ} \mathrm{C}$, which is the maximum temperature expected near the discharge. Fish surviving high temperature changes were not more susceptible to predation or disease.

Kev Words: HANFORD SITE - cooling water discharge, environmental assessment, N Reactor, N Reactor operation, representative important species, thermal plume

\section{N-15}

Nelson, J. L. 1988. Hanford Waste Vitrification Plant Preliminary Waste Form Oualification Plan EY 1988 Undate. WHC-EP-0045 REV 1, Westinghouse Hanford Company, Richland, Washington. 49 p., App. A through D.

Abstract: This plan identifies the basic steps, activities, interactions, milestones, proposed schedule, and cost estimates needed to ensure that the glass product derived from HWVP high-leveldefense waste will be acceptablefor disposal in a candidate geologic repository. The plan is updated regularly. Where possible, compliance with repository waste acceptance specifications will be achieved by directly measuring process or product variables and administrative control of the HWVP. Data collected during nonradiologic process and product tests are used to develop predictive models, and to evaluate changes in plant operating conditions and feed composition on glass form and quality. 
Kev Words: EFFLUENTS AND WASTES - highlevel waste, radioactive waste management, remedial plans, vitrification technology, waste vitrification plant

\section{$0-1$}

Oma, K. H., R. K. Farnsworth, and C. L. Timmerman. 1984. "Characterization and Treatment of Gaseous Effluents from In Situ Vitrification." Radioact. Waste Manage. Nucl. Fuel Cvcle 4:319341.

Abstract: Because in situ vitrification may be a prime candidate for stabilization of radioactive wastes, gaseous effluents must be well-characterized and efficiently treated to minimize exposures during operation. Volatilization products and entrainment behavior were determined for simulated fission products, simulated TRUs, and heavy metals in the off-gas of three pilot-scale field studies on the Hanford Site. Losses of the rare earth elements cerium, lanthanum, and neodymium used to simulate TRU species and nonvolatile simulated fission products (cobalt, molybdenum, and strontium) were very low. Cesium losses were also low, with decontamination factors from $3 \times 10^{-1}$ to $2 \times 10^{-3}$. Heavy metal losses were highest with decontamination losses ranging from 7 to 30 for lead and from 3 to 4 for cadmium. Losses of elements decreased with increasing burial depth, and increased when the surface cold cap was lost and when gas was released. Off-gasparticulate loads were highest during startup and release of combustible gas, and lowest during normal operation. An off-gas system is needed to remove submicron particles.

Kev Words: EFFLUENTS AND WASTES - highlevel waste, HWVP, impact assessment, radioactive waste management, radionuclides, remedial studies. vitrification technology, waste vitrification plant

\section{$0-2$}

Opitz, B. E., D. R. Sherwood, C. L. Nelson, and W. J. Martin. 1984. Laboratory Evaluation of 1325-N Crib Disposal Basin S e d i m e n t s . . UNI-2999 REV 0, prepared by Pacific Northwest Laboratory for UNC Nuclear Industries, Richland, Washington. 38 p., App. A.
Abstract: This study was initiated because percolation rates were declining in sediments below the $1325-\mathrm{N}$ crib to less than a desirable $3000 \mathrm{gal} / \mathrm{min}$. Experiments were conducted to identify the factors or mechanisms responsible. Based on test data and information supplied by UNC personnel, two mechanisms may be most responsible for the sediment's declining percolation rate: 1) after the rapid change from unsaturated to saturated flow conditions, the fine-grained sediment may shift, creating flowrestricting lenses and decreasing porosity; and 2) continual discharge of very fine-grain solids to the crib, followed by settling, slows percolation by plugging some drainage pathways.

Kev Words: EFFLUENTS AND WASTES - liquid effluents, soil percolation (in situ), waste disposal, $1325-\mathrm{N}$ crib, 100 Areas

\section{P-1}

Pacific Northwest Laboratory (PNL). 1982. Annotated Bibliography of Radioactive Waste Management Publications at Pacific Northwest Laboratory January 1978 through Julv 1982. PNL-4441, Nuclear Waste Technology Program Office, Pacific Northwest Laboratory, Richland, Washington. 155 p., Indexes.

Contents: PNL publications related to radioactive waste management from 1978 to 1982 were abstracted. Abstracts were grouped under three subject categories: nuclear fuels, geosciences, and general. Entries in the subject index facilitate access by specific subjects (e.g., High-Level Radioactive Wastes). There were three indexes: Author, Subject, and Report Number. Material cited include research reports, journal articles, books, patents, theses, and conference papers, but not technical progress reports. This report was the third in a series, preceded by BNWL-2201 (1965-1976) and PNL-4050 (19751978).

Kev Words: EFFLUENTS AND WASTES - bibliography (radioactive waste management), Hanford Site, waste disposal/treatment

\section{P-2}

Pacific Northwest Laboratory (PNL). 1986. GroundWater Monitoring Comoliance Proiects for Hanford 
Site Facilities. Progress Renort for the Period Mav 1 to September 30. 1986. PNL-6466, Pacific Northwest Laboratory, Richland, Washington.

Contents: Ground-water monitoring is described for May through September 1986 at four locations at Hanford: the 300 Area process trenches, the $183-\mathrm{H}$ solar evaporation basins, the 200 Area low-level burial grounds, and the nonradioactive dangerous waste landfill. Work at the first two sites was initiated in June 1985 but new wells are being added. Work at the last two sites is new and wells are being established so that monitoring can begin. This report initiates a planned series of progress reports, each of which includes a chapter for each of the four locations. In general, each chapter has a section on drilling and hydrologic characterization, and a section on routine ground-water sampling and analysis.

Kev Words: EFFLUENTS AND WASTES - environmental monitoring, ground water, hazardous materials, nonradioactive dangerous waste landfill, radioactive materials, 183 -H evaporation basins, 200 Area burial grounds, 300 Area trenches

\section{P-3}

Pacific Northwest Laboratory (PNL). 1986. Revised Ground-Water Monitoring:Compliance Plan for the 183-H Solar Evanoration Basins. PNL-6470, Pacific Northwest Laboratory, Richland, Washington. 125 p., App. A through J.

Contents: The 183-H solar evaporation basins (183H basins) have been used since 1973 by UNC Nuclear Industries for storage of mixed chemicals and radionuclides. This revised plan expands work initiated for regulatory compliance in June 1985 and is based on requirements for interim-status facilities, which do not have final permits but are authorized to operate during the permitting process. The revision is aimed at two main goals: 1) collect more site-specific hydrological data to fully characterize the area and support decisions for a monitoring well network, and 2) expand sampling and analysis to quantify existing contamination and its offsite movement.

Kev Words: HANFORD SITE - environmental monitoring, ground water, planning document, $183-\mathrm{H}$ evaporation basins, 100 Areas
Pacific NorthwestLaboratory (PNL). 1987. Environmental Monitoring at Hanford for 1986. PNL6120, Pacific Northwest Laboratory, Richland, Washington. Irregular pages, App. A through G.

Abstract: Data collected in 1986 by PNL's Environmental Monitoring Program are reviewed. Samples taken on and off the Hanford Site are used to provide data for assessing the amounts of radioactivity and chemicals from operational and natural sources. Results are given for: air, ground water, surface water, food and farm products, wildlife, soil and vegetation, and penetrating radiation. In addition, potential radiation dose to the public and quality assurance are discussed. Support data are in Appendices. Radioactivity near Hanford during 1986 was well below applicable DOE and EPA standards. Radioactive materials released at Hanford were indistinguishable off the site from background levels. Chemicals in the air were below applicablestandards of the DOE and state of Washington. Chemicals in ground water beneath Hanford came from onsite operations and natural sources. Fission products from the April 26 accident at the Chernobyl Nuclear Power Station, USSR, appeared in some samples. The calculated effective dose potentially received by a maximally exposed individual was about 0.09 mrem for 1986. The collective effective dose to the population within $80 \mathrm{~km}$ was 9 man-rem. These doses were much less than those from both common sources of radiation, such as natural background radiation, and recently recommended DOE radiation standards for protection of the public.

Kev Words: HANFORD SITE - air quality, environmental monitoring, food and farm products, ground water, Hanford Reach, penetrating radiation, public dose estimates, radioactivity,regulatory compliance, soil and vegetation, water quality

\section{P-5}

Pacific Northwest Laboratory (PNL). 1987. GroundWater Monitoring Comoliance Proiects for Hanford Site Facilities. Progress Report for the Period January 1 to March 31. 1987, Vols. 1 (58 v.). 2 \& 3 (ADD. A through I). PNL-6467, Pacific Northwest Laboratory, Richland, Washington. 
Contents: Four ground-water monitoring programs at Hanford are reviewed for the first quarter of 1987. All wells in the initial drilling phase were completed near the 300 Area trenches, the 183-H evaporation basins, and the nonradioactive dangerous waste (NRDW) landfill. Contracts are almost ready for drilling in the 200 East and 200 West areas. Results of sampling and analysis indicate that the NRDW landfill has not affected ground-waterquality. Further, fluctuations in measurements under the 300

Aree are due to specific activities, and fluctuations under the $183-\mathrm{H}$ basins are due to water table fluctuations associated with the river levels. Phase III drilling plans were finalized following discussions with the Washington State Department of Ecology.

Kev Words: EFFLUENTS AND WASTES - environmental monitoring, ground water, hazardous materials, nonradioactive dangerous waste landfill, radioactive materials, 183 -H evaporation basin, 200 Area burial grounds, 300 Area trenches

\section{P-6}

Pacific Northwest Laboratory (PNL). 1987. GroundWater Monitoring Compliance Projects for Hanford Site Facilities. Prowess Renort for the Period April 1 to June 30. 1987. PNL-6468, Pacific Northwest Laboratory, Richland, Washington. 204 p., App. A through D.

Contents: Four ground-water monitoring programs at Hanford are reviewed for the second quarter of 1987. Phase III monitoring wells were completed near the 183-H evaporation basins. An interim site characterization report was completed for the $183-\mathrm{H}$ basins, the nonradioactivedangerous waste landfill report is in clearance, and the 300 Area trenches report is under review. A contract was awarded for drilling 19 wells in the 200 West area burial grounds, and drilling began in both the 200 East and 200 West areas. Analysis of samples from the three sites with operating wells shows no deviations from established trends. The NRDW landfill does not appear to affect ground-water quality. Fluctuationsat the 300 Area trenches correspond with specific onsite activities. The distribution of chemicals in ground water beneath the $183-\mathrm{H}$ basins is unchanged.

Kev Words: EFFLUENTS AND WASTES - environmental monitoring, ground water, hazardous materials, nonradioactive dangerous waste landfill, radioactive materials, 183-H evaporation basins, 200 Area burial grounds, 300 Area trenches

\section{P-7}

Pacific Northwest Laboratory (PNL). 1987. GroundWater Monitoring Comoliance Proiects for Hanford Site Facilities. Progress Report for the Period Julv 1 to Sentember 30.1987 PNL-6469, Pacific Northwest Laboratory, Richland, Washington. 84 p., App. $\mathrm{A}$ and $\mathrm{B}$.

Contents: Four ground-water monitoring programs at Hanford are reviewed for the third quarter of 1987. Repairs were completed on five wells at the $183-\mathrm{H}$ evaporation basins. New wells were completed at the 200 Area burial grounds (25), 200 East burial grounds (14), and 200 West burial grounds (11). The Interim Characterization Report for the nonradioactive dangerous waste (NRDW) landfill was submitted to the Washington Department of Ecology and the U.S. EPA. Analysis of well water samples from the 300 Area, $183-\mathrm{H}$ basins, and NRDW landfill showed no change from previous trends. The NRDW Landfill has no apparent effect on ground-water quality, but some coliform bacteria indicate possible contamination from the adjacent solid-wastelandfill.

Kev Words: EFFLUENTS AND WASTES - environmental monitoring, ground water, hazardous materials, nonradioactive dangerous waste landfill, radioactive materials, $183-\mathrm{H}$ evaporation basins, 200 Area low-level burial grounds, 300 Area trenches

\section{P-8}

Pacific Northwest Laboratory (PNL). 1987. Peacetime Radiological Training for Firefighters. Paramedics. and Law Enforcement Personnel. PNL-6204 Rev. 1, Pacific Northwest Laboratory, Richland, Washington. $43 \mathrm{p}$.

Abstract: Good emergency planning requires that fire protection, paramedic, and law enforcement agencies be prepared for incidents involving radioactive materials. The Benton County Department of Emergency Management, with the help of local agencies, prepared this "training" manual to enable efficient response. The manual examines radioactivity and the role of firefighters, paramedics and law enforcement teams during accidents with radioactive 
materials. Brief reviews are provided of nuclear energy, basic radiation safety, instrumentation (to measure radioactivity), decontamination, response actions, and traffic accidents.

Kev Words: HANFORD SITE - emergency preparedness, radiological emergency response

\section{P-9}

Pacific Northwest Laboratory (PNL). 1988. Environmental Monitoring Master Sampling Schedule, January - December 1988. PNL-6550, Pacific Northwest Laboratory, Richland, Washington. 52 p.

Contents: Environmental monitoring on the Hanford Site is conducted by PNL for the DOE. This document contains the planned schedule for routine sample collection for CY 1988 for the surface and ground-water environmental monitoring projects. Monitoring projects evaluate the levels of radioactive and nonradioactivecontaminants in the Hanford evirons, as required by DOE Order 5480.1A and DOE Order 5484.1.

Kev Words: HANFORD SITE - environmental monitoring, ground water, sampling schedule, surface water

P-10

Page, T. L., D. D. Dauble, and D. A. Neitzel. 1982. Columbia River Aauatic Ecoloeical Studies Near the Skagit/Hanford Nuclear Proiect: Final Report. Prepared for Northwest Energy Services Company by Pacific Northwest Laboratories, Richland, Washington. $82 \mathrm{p}$.

Abstract: Data are presented and summarized on fish and benthic organisms collected near the site of the proposed Skagit/Hanford Nuclear Project (river mile 361.5) from March 1981 through April 1982. The organisms were similar to those of other aquatic communitiesin the Hanford Reach. Specifically: 1) all of the 29 species of fish had been taken previously at Hanford; 2) smallmouth bass spawned in Hanford Slough in June and July, and 0-age juveniles dispersed in December; 3) caddis fly and midge fly larvae dominated benthic samples by numbers; and 4) there were no significant inconsistencies with data reported in other aquatic studies at Hanford.
Kev Words: AQUATIC ECOLOGY - aquatic insects, benthic organisms, Hanford Reach, resident fish, Skagit/Hanford Site, smallmouth bass

\section{P-11}

Pavlina, R. S., and J. H. Rasmussen. 1987. PUREX and UO Plant Nitrogen Oxide Monitoring Plan. WHC-EP-0104, Westinghouse Hanford Company, Richland, Washington. $24 \mathrm{p}$.

Abstract: Allowable emission levels of nitrogen oxides $\left(\mathrm{NO}_{\mathrm{x}}\right.$ ) from waste processing facilities at Hanford is set by EPA, Region X. This document outlines WHC's plan to monitor emissions and exhaust from the PUREX and $\mathrm{UO}_{3}$ plants via the 291A-1 and 2\%-U-4 stacks. Five DuPont 461 photometric analyzers continuously monitor $\mathrm{NO}_{\mathrm{x}}$ concentrations in the 291-A-1 stack and at three other points in the process, while another analyzer monitors the 296U-4 stack. A KURZEVA 4000 Electronic Velocity Array continuously monitors airflow through the 291A-1 stack, and an annubar continuously monitors airflow through the 296-U-4 stack.

Kev Words: EFFLUENTS AND WASTES - gaseous effluents $\left(\mathrm{NO}_{\mathrm{x}}\right.$ ), monitoring program, PUREX Plant, $\mathrm{UO}_{3}$ Plant, 200 Areas

\section{$\mathrm{P}-12$}

Perez, J. M., and R. A. Nakaota. 1986. "Vitrification Testing of Simulated High-Level Radioactive Waste from Hanford." In Waste Management '86. Proceedings of the Svmposium on Waste Management. Vol. 2 High-Level Waste. ed. R. G. Post, pp. 495-505. University of Arizona Press, Tucson.

Abstract: The Hanford Waste Vitrification Plant may apply vitrification technology (under developmentat PNL) to solidify selected waste streams at Hanford prior to disposal in a federal repository. A reference glass and two candidate feed slumes were tested in a melter during 1985 in prototype vi cation experiments. The slurry compositions had acceptable processing characteristics in a ceramic melter. A premade glass-former frit was preferred for glass-former addition. Spinel crystal formations and settling occurred in the glass tank because of a high chromium content of the waste. The nature and extent of 
off-gas effluents were consistent with past experiments with processing slurries containing formic acid.

Kev Words: EFFLUENTS AND WASTES Hanford Site, radioactive waste, remedial studies, waste treatment, vitrification technology

\section{P-13}

Perkins, C. J. 1988. Westinghouse Hanford Company Environmental SurveillanceAnnual Renort 100 Areas. Calender Year 1987. WHC-EP-0161, Westinghouse Hanford Company, Richland, Washington. Irregular pages, App. A through $\mathrm{H}$.

Abstract: N Reactor facilities, shutdown reactors, and burial grounds in the 100 Areas were monitored in the surveillance program. Samples were collected of ambient air, vegetation, surface soil, and sediment near Liquid Waste Disposal Facilities (LWDF), and direct radiation levels were measured at several locations including the Columbia River shoreline. This report covers a 15-month span because the reporting period was shifted from the $\mathrm{CY}$ to the $\mathrm{FY}$ when WHC assumed the Operations and Engineering contract for the Hanford Site in mid-1987. N Reactor was placed on a "standdown" mode on January 7 , 1987.

Ambient Air: Levels of radionuclides in the air near $100 \mathrm{~N}$ were less than the Derived Concentration Guide (DCG). In late 1987, structural modifications to the 1301-N LWDF caused an increase in ${ }^{\circ}{ }^{\circ} \mathrm{Co}$ in the air for a short time. Ground water: Radionuclide concentrations in ground water exceeded the DCG for ${ }^{90} \mathrm{Sr}$ and ${ }^{131} \mathrm{I}$ near the 1301-N and 1325-NLWDF . Levels of ${ }^{90} \mathrm{Sr}$ also exceeded the DCG at N Springs. Tritium concentrations in ground water generally increased in the $100 \mathrm{~N}$ and $100 \mathrm{~K}$ areas, but did not exceed the DCG. Soil and Vegetation: Nearbackground levels of radionuclides were found in surface soil and vegetation at the $100 \mathrm{~N}$ Area. Vegetation near N Springs contained elevated levels of ${ }^{90} \mathrm{Sr}$. Residual levels of radionuclides occurred in surface soil and vegetation near the 1301-NLWDF facility, which has received no $100 \mathrm{~N}$ Reactor effluent since September 1985. External Radiation: Five thermoluminescentdosimeter sites were added to the $100 \mathrm{~N}$ Area in October 1986, bringing the total to 41. Dose rates were briefly elevated at TLD sites near the 1310-N RadioactiveChemical Storage facility. Radiation levels were elevated in controlled areas near 1301-N and 1315-N LWDFs. Radiological Surveys: Measurements of direct radiation near 1301-N LWDF, along the Columbia River shoreline, and near the 1325-N LWDF were higher than in years prior to 1986, and were attributed to standdown of N Reactor (absence of shielding water), an increased inventory of radionuclides, and low water levels in the Hanford Reach. Liquid Waste Disposal Facilities: Sediment samples from 1325-N LWDF contained residual activation and fission products from N Reactor. Radioactivity will decline as nuclides decay at both LWDF sites.

Kev Words: EFFLUENTS AND WASTES - environmental monitoring, ground water, high-level wastes, N Reactor, radioactive waste, surface soil/ vegetation, 100 Areas, $100 \mathrm{~N}$ shoreline springs, 301N LWDF, 1315-N LWDF, 1325 N LWDF

\section{P-14}

Petron, S. E. 1987. Thermoregulation in the Hanford. Washington Elk Herd. Ph.D Thesis, Washington State University, Pullman, Washington. 83 p.

Abstract: Body temperature (BT) rhythms in five wild elk were monitored with radiotelemetry in the semiarid, shrub-steppe of southcentral Washington (Hanford Site). Overall mean BT equaled $38.4^{\circ} \mathrm{C}$ during both summer and winter. Average diurnal BT varied $1.1^{\circ} \mathrm{C}$ during summer and $0.6^{\circ} \mathrm{C}$ during the winter. Mean minimum BT occurred 6 hr after sunrise both summer and winter. Mean maximum BT occurred $17 \mathrm{hr}$ after sunrise in summer and $15 \mathrm{hr}$ after sunrise in winter. Water content in forage plants decreased from $70 \%$ in April to $10 \%$ in July. When fed tritiated water, penned elk used an estimated 4.6 $\mathrm{kg}$ of water during spring and $10.6 \mathrm{~kg}$ of water during summer per $100 \mathrm{~kg}$ body weight/day. Based on implanted sensors and radiotelemetry, subcutaneous temperatures in elk during summer showed a linear increase with operative temperatures(OT) up to, but not above, $30^{\circ} \mathrm{C}$. During winter, subcutaneous temperatures were not correlated with OT, and were maintained $1^{\circ} \mathrm{C}$ below BT in nonbreeding bulls and cows. Body temperature was independent of OT both winter and summer. Elk preferred sagebrush as bedding habitat during both winter $(73 \%)$ and summer (69\%), but used shade more often during summer (53\%) than during winter (27\%). 
Kev Words: TERRESTRIAL ECOLOGY - elk, habitat use, body temperature, thermoregulation

\section{P-15}

Petron, S. E., F. G. Gilbert, and W. H. Rickard. 1987. "Portable Automatic Radiotelemetry Recording System." = 15:421-426.

Abstract: A system is described to monitor freeroaming animals with radiotelemetry by means of portable, battery-powered microcomputers. Data can be transferred to a computer without manual transcription. An important feature of this system is the recording of accurately timed pulse rates and real time. It was developed and tested with elk on the Hanford Site.

Kev Words: TERRESTRIAL ECOLOGY - automatic recording,elk, radiotelemetry,

\section{P-16}

Phillips, S. J., M. R. Adams, T. W. Gilbert, C. C. Meinhardt, R. M. Mitchell, and W. J. Waugh. 1985. Engineered Barrier Test Facility Status Report: 1984. RHO-WM-SR-3 P, Rockwell Hanford Operations, Richland, Washington. 32 p., App. A through M.

Abstract: Engineered barrier cover systems are being developed and evaluated as a cost-effective alternative for isolation of burial grounds, cribs, caissons, tanks, etc., at Hanford. This report describes the status of these activities. Comparative cover systems have been built at the Hanford Engineered Barrier Test Facility in the 200 West Area. Designs include 1) mounded (monolithic) soil, 2) mounded (monolithic) rock, 3) impermeable surface layer with offflow of precipitation,4) multilayer (earth materials) infiltration/biotic intrusion, and 5) multilayer (earth materials) biotic intrusion. FY 1985 activities include construction of a refined multilayer (earth material and woven glass) with intrusive markers. The design, specifications, materials, and construction of existing barriers are summarized in the text. Categories of monitoring systems installed at field test facilities include micrometeorologic, soil physics, soil mechanics, plant intrusion, and animal intrusion. Descriptions, placement, and examples of monitoring transducers, modules, and systems are discussed.
Also, the methods to conceptually design and evaluate engineered barriers are outlined, along with cost estimates and examples of hypothetical designs.

Kev Words: EFFLUENTS AND WASTES - barrier systems, Hanford Site, radioactive waste management, remedial studies, shallow land burial, waste disposal/treatment

\section{P-17}

Phillips, S. J., L. L. Ames, R. E. Fitzner, G. W. Gee, G. A. Sandness, and C. S. Simmons. 1980. Characferization of the Hanford 300 Area Burial Grounds. Final Renort. Decontamination and Decommissioning. PNL-2557, Pacific Northwest Laboratory, Richland, Washington. $237 \mathrm{p}$.

Abstract: Unique functional geophysics, geochemical, soil physics, numerical modeling, and biological methods were needed to better characterize and monitor buried radioactive waste disposal sites at Hanford. Four tasks were undertaken to meet these needs: 1) geological surveys to locate and define gross composition of waste materials, 2) analysis of the interaction of disposed radionuclides with geologic media, 3) verification of computer modeling of water movement in partially saturated groundwater systems, and 4) evaluation of biological organisms for potential uptake and transport of radionuclides. Results indicated that the $\mathbf{3 0 0}$ Area burial grounds were adequate in containing radioactive waste. Alternatives for decommissioning were exhumation and translocation, entombment, perpetual care, and abandonment. Perpetual care (now used) now seems to be the best decommissioning alternative for these burial grounds.

Kev Words: EFFLUENTS AND WASTES - alternatives assessment, radioactive waste, remedial studies, 300 Area burial grounds

\section{P-18}

Phillips, S. J., and R. A. Carlson. 1981. Alternatives foControl Subsidence at Low-Level Radioactive Waste Burial Sites. RHO-LD-172, Rockwell Hanford Operations, Richland, Washington. 25 p. 
Abstract: A substantial amount of low-level radioactive and hazardous wastes have been interred in shallow land burial structures throughout the United States. Many of these structures (trenches, pits, and landfills) have geotechnical subsidence problems and may require stabilization. Ground surface manifestations of subsidence include large cracks, basins, and cave-ins. Subsidence is primarily caused by void filling, and by physicochemicaldegradation and solubilization of buried wastes. These surface features represent potential transport to the biosphere. Engineering alternatives to reduce buried waste and mamx material voids were identified, discussed, and evaluated. Falling mass, pile driving, and in situ incineration engineering alternatives were selected for further development.

Kev Words: EFFLUENTS AND WASTES - buried waste, buried waste subsidence, Hanford Site (general), radioactive waste management, waste disposal/treatment

\section{P-19}

Phillips, S. J., and T. W. Gilbert. 1987. "Stabilization and Isolation of Low-Level Liquid Waste Disposal Sites." In Waste Management '87, Proceedings of the Symposium on Waste Management, Vol. 3 Low-Level Waste, ed. R. G. Post, pp. 55-62. University of Arizona Press, Tucson, Arizona.

Abstract: Rockwell is developing equipment to stabilize and isolate low-level radioactive liquid waste disposal sites. This is accomplished by a dynamic consolidation and particulate grout injection system with the following components: 1) a mobile grout plant for transporting, mixing, and pumping particulate grout; 2) a vibratory hammer/extractor for consolidation of waste, backfill, and emplacement of the injector; 3) consolidation/injector probe for introducing grout into fill material; and 4) an openvoid surface injector. The surface injector uses surface or subsurface mechanical or pneumatic packers and displacement gas filtration for introducing grout into access piping of disposal structures. Treatment of a waste disposal site yields a physically stable, cementitious monolith.

Kev Words: EFFLUENTS AND WASTES - grout technology, Hanford Site, injection system, waste treatment
Phillips, S. J., and J. N. Hartly. 1986. "Protective Barrier Systems for Final Disposal of Hanford Waste Sites." In Waste Management'86. Proceedings of the Symnosium on Waste Management. Vol. 1 General Interest, ed. R. G. Post, pp. 433-437. University of Arizona Press, Tucson, Arizona.

Abstract: A protective barrier system is under development for possible application in the final disposal of defense wastes at the Hanford Site. Function requirements for the protective barrier are control of water infiltration, wind erosion, and plant and animal intrusion into the waste zone. The barrier must also function without maintenance for the required time, up to 10,000 years. Progress and plans to design and test protective barriers at Hanford are summarized.

Kev Words: EFFLUENTS AND WASTES - barrier systems, buried waste, Hanford Site, radioactive waste, remedial plans, waste disposal/treatment, radioactive waste management

\section{P-21}

Poole, L. D., N. V. Marr, and S. M. McCorquodale. 1988. Productivitv. Mortality, and Response to Disturbance of Nesting Swainson's Hawks on the Hanford Site. PNL-6496, Pacific Northwest Laboratory, Richland, Washington. 26 p.

Abstract: This is one of seven Environmental Topical Reports produced by BWIP before the effort ended in late 1987. The reports provided environmental information at Hanford, then a possible site for the nation's first geologic repository for radioactive wastes. The number of nesting Swainson's hawks increased from 17 to 36 pairs since 1978. During 1987, 35 occupied nests were in trees and 1 was on a utility pole. An average of 2.0 young were fledged per nest. In 11 nesting territories used to evaluate mortality, 1 of 22 adult hawks and 10 of 30 juvenile hawks died before migration, apparently from starvation or dehydration. Perching and flying were the dominant activities. Home ranges of radiotagged hawks averaged $6.78 \mathrm{~km}^{2}$. The hawks appeared to be disturbed by pedestrians and slowmoving vehicles near nests. Novel events were more likely to evoke response than recurring events. When disturbed, adult hawks usually flew toward the 
disturbance, juvenile hawks flew away. Methods to mitigate against human activity are suggested.

Kev Words: TERRESTRIAL ECOLOGY - behavior, effect of human activity, habitat use, home range, nesting, reproduction, Swainson's hawk

P-22

Prater, L. S., J. T. Rieger, C. S. Cline, E. J. Jensen, T. L. Liikala, K. R. Oster, and P. A. Eddy. 1984. Ground-Water Surveillanceat the Hanford Site for CY-1983. PNL-5041, Pacific Northwest Laboratory, Richland, Washington. 39 p., App. A through C.

Abstract: Sampling of monitoring wells (324) for radioactiveand chemical constituents continued during 1983. The distributions of tritium, nitrate, and gross beta in ground water beneath the Hanford Site was determined. Tritium and nitrate plumes from the 200 Areas continued to move generally eastward toward the Columbia River, with slight changes on the edges. Gross beta activity was low and limited in distribution. Two potential pathways for transfer of radionuclides from ground water were examined consumption by humans from onsite wells and seepage into the Columbia River. In 1983, the annual whole body dose received from drinking water at the FFTF, one of four points using ground water onsite, was calculated to be $0.4 \mathrm{mrem}$ (based on ingestion of $250 \mathrm{ml} /$ year - about $1 / 2$ the average annual consumption of an adult) and a dose commitment of 50 years; this estimate was $10 \%$ of the Washington State drinking water standard. Tritium was detected in riverbank springs, confirming that it entered the Hanford Reach via underground flow. In 1983, dilution soon rendered ground water's contribution of tritium in the river to levels indistinguishable from background. Supporting studies showed that tritium levels in riverbank wells changed seasonally because of bank storage and fluctuations in river flow. Also, a new ground-water mound formed beneath a new crib in the $100 \mathrm{~N}$ Area, while the old mound under the former crib flattened.

Key Words: HANFORD SITE - environmental monitoring, ground water, nitrates, river water, tritium, water quality, 100 Areas, 200 Areas
Price, K. R. 1981. Carbon-14 in Sagebrush on the Hanford Site and Vicinitv. PNL-3766, Pacific Northwest Laboratory, Richland, Washington. 9 p.

Abstract: Levels of ${ }^{14} \mathrm{C}$ were estimated in sagebrush to examine relationships between past and present operations on the Hanford Site. Mature sagebrush were collected at one onsite and two offsite locations - one $60 \mathrm{~km}$ upwind and one $26 \mathrm{~km}$ downwind from fuel processing facilities at Hanford. Results showed no statistically significant increased levels of ${ }^{14} \mathrm{C}$ for any time that the fuel reprocessing facilitiesoperated. However, the ${ }^{14} \mathrm{C}$ content of samples representing the post-nuclear era (after 1944) was $30 \%$ higher than in samples from the prenuclear era. The increase was attributed primarily to worldwide fallout from atmospheric tests.

Sagebrush near the PUREX reprocessing facility contained about a fourfold increase in ${ }^{14} \mathrm{C}$. This implied that, within $0.5 \mathrm{~km}$ of the plant and during the growing seasons when the facility was operating, sagebrush were exposed to average air concentrations at about 4 times normal, or an estimated $4 \mathrm{pCi} / \mathrm{m}^{3}$ of ${ }^{14} \mathrm{C}$. Sagebrush can record historical changes in ${ }^{14} \mathrm{C}$ assimilation.

Kev Words: RADIOACTIVITY - assessment, atmospheric dispersion, biomonitoring, carbon-14, Hanford Site emissions, onsite/offsite data, PUREX Plant, sagebrush

\section{P-24}

Price, K. R. 1986. Environmental Monitoring at Hanford for 1985. PNL-5817, Pacific Northwest Laboratory, Richland, Washington. Irregular pages, App. A through F.

Abstract: Data collected in 1985 by PNL's Environmental Monitoring Program are reviewed. Samples taken on and off the Hanford Site provide data to estimate amounts of radioactivity and chemicals from operational and natural sources. Results are given in the chapters: Air, Columbia River, Ground Water, Surface Water, Foodstuffs, Wildlife, Soil and Vegetation, Penetrating Radiation (all radiological), Air Quality, Ground Water, and Columbia River (all 
nonradiological). In addition, Radiological Impact from 1985 Hanford operations and Quality Assurance are discussed. Support data are in Appendices.

The calculated 50-year, whole-body dose received by a hypothetically maximally exposed individual was about 3 mrem during 1985 . This increase of 1 mrem over 1984 was attributed primarily to increased releases of ${ }^{90} \mathrm{Sr}$ from the N Reactor to the Hanford Reach. The calculated whole-body dose over 50 years to the population within $80 \mathrm{~km}$ of Hanford was 7 man-rem, an increase over the estimated 5 man-rem for 1984. In comparison, about 100 mrem were received annually by an average individual and 34,000 man-rem by the surrounding population from natural radiation and from worldwide fallout. The major sources of radionuclides to the Columbia River were liquid disposal facilities near the $\mathrm{N}$ Reactor and ground water beneath Hanford. In 1985, ground water was analyzed for hazardous materials the first time; many of the detected constituents would occur in natural ground water. Hanford operations had no effect on water quality in the Columbia River.

Key Words: HANFORD SITE - air quality, environmental monitoring, food and farm products, ground water, Hanford Site emissions, public dose estimates, regulatory compliance, soil and vegetation, water quality

\section{P-25}

Price, K. R. 1988. A Review of Historical Data on the Radionuclide Content of Soil Samoles Collected from the Hanford Site and Vicinity. PNL-6734, Pacific Northwest Laboratory, Richland, Washington. 19 p., App. A through C.

Abstract: Radioactivity has been measured in soil samples collected from the Hanford Site and vicinity since 1971 as part of the environmental monitoring program. In addition, soil samples have been collected and analyzed for special purpose studies. This report reviews and summarizes the historical results of soil sampling from the late 1950's through 1987. It also provides previously unpublished data and consolidates results from routine environmental monitoring and special studies into one document. The sources reviewed included the environmental monitoring computerized data base, historical files, annual environmental monitoring reports, and other
Hanford documents. A rigorous evaluation of data from these sources was not conducted. Several observations were made during the review in respect to past Hanford operations and soil sampling: 1) no gross contamination of offsite environs was revealed; 2) some locations near onsite facilities received contamination; 3) no gradual buildup or depletion of contamination at any sampling location was indicated; 4) results varied among aliquots of one sample, or among multiple samples collected at one location; and 5) radionuclides from Hanford have been difficult to identify in the presence of worldwide fallout.

Kev Words: RADIOACTIVITY - assessment, atmospheric dispersion, environmental monitoring, Hanford Site emissions, historical review, radiation data, surface soil, offsite/onsite data

\section{P-26}

Price, K. R. 1988. "Plutonium in Surface Soil from the Environs of the Hanford Site." 33rd Annual Meeting, 54:\$69 (abstract). Health Physics Society, Rochester, Minnesota.

Abstract: Samples of surface soil have been routinely collected and analyzed for plutonium by alpha spectrometry since 1971 . The annual average concentration of ${ }^{239 / 240} \mathrm{Pu}$ in soil samples collected offsite has ranged from 0.010 to $0.008 \mathrm{pCi} / \mathrm{g} \mathrm{(+/-} 2$ standard error of the mean), with no obvious influence of past and present operations at Hanford. Alpha spectrometry is not sensitive enough to identify small amounts of Hanford-derived plutonium in the presence of worldwide fallout. However, the percentage of plutonium originating at Hanford can be calculated by the isotopic ratio of ${ }^{240} \mathrm{Pu}$ to ${ }^{239} \mathrm{Pu}$. The maximum amount of plutonium from Hanford was an estimated $17 \%$ of the total plutonium at locations around the site perimeter. Hanford-derived plutonium was not detected in surface-soil samples collected from upwind or distant locations.

Key Words: RADIOACTIVITY - assessment, atmospheric dispersion, environmental monitoring, Hanford Site emissions, plutonium, offsite/onsite data, surface soil 
Price, K. E., P. J. Blumer, J. M. V. Carlile, R. L. Dirkes, and M. S. Trevathan. 1984. Environmental Status of the Hanford Site for CY-1983. PNL-5039, Pacific Northwest Laboratory, Richland, Washington. $51 \mathrm{p}$.

Abstract: Data are presented from surface samples taken on the Hanford Site in 1982 by PNL's Environmental Monitoring Program. Radiological conditions near operating areas, unusual occurrences at operating areas, and radioactive and nonradioactive discharges are reported and discussed. General levels of airborne particulate radioactivity were lower in 1983 than in 1982, as radionuclides associated with worldwide fallout continued to decline. Airborne ${ }^{90} \mathrm{Sr}$, ${ }^{137} \mathrm{Cs}$, and plutonium concentrations were not significantly different from background levels, and ${ }^{131}$ I was not identified in any air sample. Tritiun concentrations were similar at all sampling locations and reflected only worldwide fallout, as in previous years. Cesium-137 in B Pond continued to decrease from a peak in 1980. Strontium-90levels in B Pond, and radionuclides in other onsite ponds, remained at levels similar to those in 1982. Tissue samples from wildlife showed some Hanford-produced radionuclides. While several onsite soil and vegetation samples contained radionuclides above background levels, concentrations were similar to those reported in recent years. External penetrating dose measurements in 1983 remained unchanged. No significant contamination was found during routine road and railroad surveys. No significant changes were observed in the radiological status of waste burial grounds outside of operating area fences. Seven unusual occurrences related to the environment were reported at Hanford in 1983.

Kev Words: RADIOACTIVITY - assessment, environmental monitoring, Hanford Site emissions, radionuclides

\section{P-28}

Price, K. R., L. L. Cadwell, R. G. Schreckhise, and F. P. Brauer. 1981. Iodine-129 in Forage and Deer on the Hanford Site and Other Pacific Northwest Locations. PNL-3357, Pacific Northwest Laboratory, Richland, Washington. 17 p., App. A and B.
Abstract: This report establishes current (1978) levels of ${ }^{129} \mathrm{I}$ in deer, forage, and soil samples from the Hanford Site and from other locations in the Pacific Northwest. The thyroid glands of deer at Hanford contained about 2,700 times more ${ }^{129}$ than deer at Bend, Oregon or Centralia, Washington. Deer at Bend and Centralia contained about 5 times as much ${ }^{129} \mathrm{I}(15 \mathrm{fCi} / \mathrm{g}$ wet weight) than values reported from deer in the central United States. The average concentration of ${ }^{129} \mathrm{I}$ in deer thyroids at Hanford in 1978 was similar to samples collected 14 years earlier. Concentrations of ${ }^{129} \mathrm{I}$ in soil, litter, forage, and other deer samples generally decreased in the order: Hanford; Wooten Game Range, Washington; Wenatchee, Washington; Centralia/Bend, Washington - a decline corresponding to increasing distance from Hanford. Levels of ${ }^{129} \mathrm{I}$ in surface soil and vegetation in or on the Hanford Site in 1978 were generally lower than levels in 1972 and 1974, concomitant with reductions in ${ }^{129} \mathrm{I}$ releases from onsite operations. Current levels diminish with distance from the 200 Areas. Onsite concentrations of ${ }^{129} \mathrm{I}$ (dry weight basis) ranged from 0.14 to $15 \mathrm{fCi} / \mathrm{g}$ in surface soil; 0.04 to $14 \mathrm{fCi} / \mathrm{g}$ in litter; 0.019 to $2 \mathrm{fCi} / \mathrm{g}$ in grass; and 0.025 to $2.4 \mathrm{fCi} / \mathrm{g}$ in shrubs.

Kev Words: RADIOACTIVITY - assessment, iodine-129, onsite/offsite data, surface soil, vegetation, wildlife (mule deer)

\section{P-29}

Price, K. R., and J. M. V. Carlile. 1985. Environmental Monitoring:at Hanford for 1984. PNL-5407, Pacific Northwest Laboratory, Richland, Washington. Irregular pages, App. A through F.

Abstract: Data collected in 1984 by PNL's Environmental Monitoring Program are reviewed. Samples taken on and off the Hanford Site provide data to assess amounts of radioactivity and chemicals from operational and natural sources. Results are given in the chapters: Airborne Radioactivity, Water Monitoring, Nonradiological Monitoring, Ground Water, Foodstuffs, Wildlife, Soil and Vegetation, and External Radiation. In addition, Radiological Impact (Radiation Dose) attributable to Hanford operations and Quality Assurance are discussed. Support data are in Appendices. 
The calculated 50-year whole body dose that might be received by a maximally exposed individual was about 2 mrem in 1984. This was an increase since 1983 , and was attributed to higher releases of ${ }^{90} \mathrm{Sr}$ from N Reactor to the Hanford Reach. The calculated 50-year whole body dose to the public within 80 $\mathrm{km}$ of the site was about 5 man-rem. These doses were considerably less than doses that might be received from other common sources of radiation, and well within regulatory requirements. Gross beta radioactivity in airborne particulates were lower in 1984 than in 1983 as a result of declining world-wide fallout. Concentrationsof ${ }^{3} \mathrm{H},{ }^{90} \mathrm{Sr},{ }^{129} \mathrm{I}$, and uranium (natural) in the Columbia River were slightly higher downstream from Hanford than above, but still well below applicable concentration guides. Ground water and $\mathrm{N}$ Reactor effluents contributed small amounts of radioactivity to the Columbia River, but water quality was not affected. Emissions of $\mathrm{NO}_{\mathbf{x}}$ to the air did not exceed EPA or local limits.

Kev Words: HANFORD SITE - air quality, environmental monitoring, food and farm products, ground water, Hanford Reach, penetrating radiation, public dose estimates, radioactivity, regulatory compliance, soil and vegetation, water quality

\section{P-30}

Price, K. R., J. M. V. Carlile, R. L. Dirkes, and M. S. Trevathen. 1984. Environmental Surveillance at Hanford for CY-1983. PNL-5038, Pacific Northwest Laboratory, Richland, Washington. 50 p., App. A through E.

Abstract: Data collected in 1983 by PNL's Environmental SurveillanceProgram are reviewed. Samples on and off the Hanford Site provide data to assess the amounts of radioactivity and chemicals from operational and natural sources. Results are given under the chapters: Airborne Radioactivity,Columbia River Radiological, Columbia River Nonradiological, Ground Water, Foodstuffs, Wildlife, Soil and Vegetation, and External Radiation. In addition, Radiological Impact of Hanford operations in 1983 and Quality Assurance are discussed. Support data are in Appendices.

The radiation dose to the pubic in 1983 was similar to 1982 , i.e., well below all applicable regulatory limits and considerably less than potential doses from other common sources of radiation. The 50-year whole body, cumulative dose that might be received by a hypothetical maximally exposed individual was $1 \mathrm{mrem}$. The 50-year whole body cumulative dose to the population within 80-krn of Hanford was an estimated 4 man-rem. Airborne radioactivity at the site perimeter was similar to activity at offsite control locations. Concentrations of ${ }^{3} \mathrm{H},{ }^{90} \mathrm{Sr},{ }^{129} \mathrm{I}$, and uranium (natural) in the Columbia River were slightly higher below Hanford, but still way below DOE concentration guides. Ground water and N Reactor effluents contributed small amounts of radioactivity to the Columbia River, but did not affect its water quality.

Kev Words: HANFORD SITE - air quality, environmental monitoring, food and farm products, ground water, Hanford Reach, penetrating radiation, public dose estimates, radioactivity, regulatory compliance, soil and vegetation, water quality

\section{P-31}

Price, K. R., and R. L. Dirkes. 1981. Plutonium in Surface Soil Near the Southwestern Boundary of the Hanford Proiect. PNL-3647, Pacific Northwest Laboratory, Richland, Washington. 13 p., App. A.

Abstract: Samples of airborne particulates from near the Prosser Barricade in another study showed low ratios of ${ }^{240} \mathrm{Pu}$ to ${ }^{239} \mathrm{Pu}$ indicative of plutonium produced at Hanford. To locate remains of a large, short-term release of plutonium that may have occurred in the past, surface soil samples were collected along the southwestern boundary of the Hanford Site in December 1979. Slightly elevated levels of ${ }^{240 / 239} \mathrm{Pu}(0.016 \mathrm{pCi} / \mathrm{g})$ occurred in the general vicinity of the Arid Land Ecology field lab extending to the junction of Highway 240 and Horn Rapids Road, compared to lower levels $(0.006 \mathrm{pCi} / \mathrm{g})$ to the northwest along the base of Rattlesnake Mountain and the eastern slope of Yakima Ridge. Assuming the worldwideaverage ${ }^{240} \mathrm{Pu}$ to ${ }^{239} \mathrm{Pu}$ ratio of 0.18 for soil in the Pacific Northwest, the plutonium in these soil samples may be slightly less enriched with ${ }^{240} \mathrm{Pu}\left({ }^{240} \mathrm{Pu} /{ }^{39} \mathrm{Pu}=0.16\right)$. No evidence was found that an acute release remained intact and crossed the southwestern boundary of the Hanford Site during the operating history of plutonium facilities in the 200 Areas. Results were as expected, based on previous studies of airborne releases of 
radioactive materials from Hanford, prevailing wind patterns, and distribution of airborne contaminants.

Kev Words: RADIOACTIVITY - assessment, Hanford Site releases, plutonium, plutonium-240/239 ratio, surface soil

\section{$\mathrm{P}-32$}

Price, K. R., R. O. Gilbert, and K. A. Gano. 1981. Americium-241 in Surface Soil Associated with the Hanford Site and Vicinity. PNL-3731, Pacific Northwest Laboratory, Richland, Washington. $15 \mathrm{p}$.

Abstract: Surface soil samples were analyzed for ${ }^{241} \mathrm{Am}$ to evaluate improvements in surveying possible soil contamination on the Hanford Site. Results indicate that changes in procedures would not result in a major improvement. Conclusions were tempered by very low levels of ${ }^{241} \mathrm{Am}(<0.10 \mathrm{pCi} / \mathrm{g}$ dry weight) in surface soil samples, and by the type of tests required to show statistical significance. In general, the average concentration of ${ }^{241} \mathrm{Am}$ in the soil crust ( 0 to $1.0 \mathrm{~cm}$ deep) was higher than in the corresponding subsurface layer (1.0 to $2.5 \mathrm{~cm}$ deep), and the average concentration of ${ }^{241} \mathrm{Am}$ in some samples near the PUREX facility was greater than in comparable samples collected $60 \mathrm{~km}$ upwind (offsite).

Kev Words: RADIOACTIVITY - americium-241, assessment, Hanford Site releases, PUREX Plant, surface soil, 200 Areas

\section{P-33}

Price, K. R., and R. E. Jaquish. 1983. "Quality Control Activities of the Hanford Environmental Surveillance Program." In Proceedings. Fourth DOE Environmental Protection Information Meeting, pp. 135-140. CONF 821215, National Technical Information Service, Springfield, Virginia.

Abstract: A comprehensive approach to quality control (QC) was developed at PNL for environmental surveillance on the Hanford Site. The framework is documented in a QC implementation guide, which specifies $Q C$ requirements and describes specific responsibilities and authorities. Subjects in the guide include the collection, analysis, and reporting of samples, as well as equipment calibration and maintenance, training, audits, and record keeping. A QC file and library is used to store pertinent documents, records, and references for ready access.

Kev Words: HANFORD SITE - environmental monitoring, quality assurance, quality control requirements, overview

\section{P-34}

Price, K. R., and R. R. Kinnison. 1982. Uranium and Other Heavv Metals in Soil and Veeetation from the Hanford Environs. PNL-4466, Pacific Northwest Laboratory, Richland, Washington. $31 \mathrm{p}$.

Abstract: Strong winds that could transport contaminated dust and other materials offsite from the $\mathbf{3 0 0}$ Area at Hanford typically blow from the west or southwest. Samples were collected from a study area across the Columbia River and downwind from the 300 Area to estimate concentrations of uranium and other heavy metals in soils and vegetation. Results were compared to similar measurements collected at control sites, and used to test hypotheses that uranium and other heavy metals had been transported offsite by prevailing winds. Operations in the 300 Area apparently had no detectable impact on the east side of the Columbia River. While the concentration of uranium in soil from the study area was statistically greater than comparable control samples, there was no evidence that other than naturally occurring uranium was present. Concentrations of lead, silver, zinc, or copper in soil samples from the study area were not statistically different from those at control sites. Concentrations of uranium or other heavy metals in vegetation did not differ statistically among sites.

Kev Words: RADIOACTIVITY - assessment, environmental monitoring, heavy metals, onsite/offsite data, surface soil, uranium, vegetation 
Quinn, D. J., P. C. McNamee, R. G. Baca, and D. E. Wood. 1980. An Assessment of the Risks Associated With Continued Storage of High-Level Waste in Single-Shell Tanks at Hanford. RHO-LD-55, Rockwell Hanford Operations, Richland, Washington. $123 \mathrm{p}$.

Abstract: Potential risks with the continued storage of high-level defense waste in single-shell (SS) storage tanks over the next few decades were considered. The first decade (1980-1980) is analyzed in detail to provide a time frame for computation. Decay of radionuclides reduces the risk after 10 years, so results represent an upper limit to the risk during subsequent decades. The risk methods developed and described include identifying the events that may initiate radioactive material to leave SS tanks, tracing possible transport offsite with a quantitative systems model, and calculating population exposure and resulting health effects (fatal cancers and genetic abnormalities).

Analysis indicates about one chance in 80,000 of a fatal cancer $\alpha$ curring among the regional population from a decade of storage. Individual risk is about one in 20 billion of a fatal cancer in the population after a decade, compared to one in four of fatal cancer from other causes. Genetic risk is about one in 50,000 of a defect in the population over several generations, compared to congenital abnormalities from other causes of about $6 \%$ of live births. Assessment of higher consequences indicates about one chance in 40 million of an accident resulting in one or more fatal cancers. Of the accident sequences considered, the event with the highest risk is structural failure leading to dome collapse. The contribution from tank leaks is over $\mathbf{1 0 0 0}$ times smaller.

Key Words: EFFLUENTS AND WASTES - alternatives assessment, radioactive waste, release scenarios, single-shell tanks, tank integrity, radioactive waste management, 200 Areas

\section{R-1}

Raedeke, K. J., E. H. Memll, and S. M. McCorquodale. 1986. "Estimates of Intrinsic Growth Rates in Three Elk Populations in Washington." In
Proceedings 1986 Western States and Provinces Elk Workshon, ed. D. L. Eastman, 11 p. Oregon Department of Fish and Wildlife, Portland, Oregon.

Abstract: Population growth rates during the initial phase of expansion were compared among three elk populations in Washington State. Two populations experienced eruptive growth after introduction into new areas (Rocky Mountain elk), while the third grew exponentially during recolonization of the blast zone at Mt. St. Helens (Roosevelt elk). Elk on the ALE Reserve, in the sagebrush-steppe of central Washington (Hanford Site), most closely approached a maximum "intrinsic growth rate" because emigration and mortality were minimal, and immigration was not a factor.

Kev Words: TERRESTRIAL ECOLOGY - ALE Reserve, elk, population increase

\section{R-2}

Ramsdell, J. V. 1981. Hanford 200 East Area Ambient NOx Concentrations February 1968 through Februarv 1969. PNL-3996, Pacific Northwest Laboratory, Richland, Washington. 20 p.

Abstract: All available data on oxides of nitrogen (NO) emitted when the PUREX Plant at Hanford was operating was analyzed. The national air quality standard for $\mathrm{NO}_{\mathbf{x}}$ today is $50 \mathrm{ppb}$. In addition, $\mathrm{NO}_{\mathbf{x}}$ was measured at three locations near the 200 East Area from late February 1968 through February 1969. Average annual concentrations were estimated to be near or below the $12 \mathrm{ppb}$ detection threshold. However, hourly average concentrations sometimes exceeded $50 \mathrm{ppb}$, and short peaks exceeding $200 \mathrm{ppb}$ were observed. Peak emissions tended to be correlated with PUREX releases, but this was not the only source of $\mathrm{NO}_{\mathbf{x}}$. The 200 East power plant and the 244-AR vault also contributed.

Kev Words: EFFLUENTS AND WASTES airborne emissions, PUREX Plant, oxides of nitrogen $\left(\mathrm{NO}_{\mathbf{x}}\right), 200$ Areas 
R-3

Ramsdell, J. V., and G. F. Athey. 1981. MESOI: An Interactive Lagrangian Traiectorv Puff Diffusion Model. PNL-3998, Pacific Northwest Laboratory, Richland, Washington. 79 p.

Abstract: MESOI is an interactive Lagrangian puff diffusion model, where puff trajectories are determined from spatially and temporally varying wind fields. Diffusion in the puffs is computed as a function of distance traveled and atmospheric stability. Exposures are computed at nodes of a 31 by 31 grid. MESOI also provides for interpolation of short-term exposures at off-grid locations.

This report discusses the theoretical basis of MESOI, the numerical approach used, and its sensitivity and accuracy. The computer program is described, and a listing of the code is provided. A companion report (see A-28) provides a user's guide to MESOI.

Kev Words: AIR AND ATMOSPHERE- atmospheric dispersion, computer program, MESOI model

\section{R-4}

Rarnsdell, J. V., C. S. Glantz, and R. E. Kerns. 1985. "Hanford Atmospheric Dispersion Data: 19591974." Atmosph. Environ. 19:83-86.

Abstract: More than 300 atmospheric dispersion experiments were conducted at the Hanford Site involving surface and elevated releases from 1959 to 1974. In this effort, samples were collected a) near ground level $(1.5 \mathrm{~m})$ at distances from 100 to 25,000 $\mathrm{m}$ and $\mathrm{b}$ ) on towers to distances of $3,200 \mathrm{~m}$. The diffusion grid, the five tracers used (fluorescein, ${ }^{85} \mathrm{Kr}$, rhodamine-B, ${ }^{133} \mathrm{Xe}$, and zinc sulfide), and the experiments are briefly described. Documents containing the experimental data are listed.

Kev Words: AIR AND ATMOSPHERE - atmospheric dispersion, data collection, tracer studies

\section{R-5}

Rasmussen, O. R. 1980. Hanford Radioactive Tank Cleanout and Sludge Processing. RHO-ST-30, Rockwell Hanford Operations, Richland, Washington. 38 P.

Abstract: Sluicing for large-scale removal of radioactive sludges from underground storage tanks has been used successfully at Hanford. Most effort has been to retrieve relatively small amounts of sludge (2,000 to 4,000 gal) for batch dissolution and shipment to uranium or fission product separations plants, but sludge has also been transferred between million-gallon tanks. The Hanford sluicing system uses recirculating water to carry sludge from underground storage tanks to the receiver. For recovering batch sludge, the water/slurry mix is recirculated until concentration reaches the range of 10 to $20 \%$ solids. Solids are then settled, the supernatant decanted to a sluice tank, and the solids remaining in the sludge receiver are shipped to a dissolution tank for further processing. Underground storage tanks $75 \mathrm{ft}$ in diameter have been cleaned out until only 2,000 - to 4,000-gal of sludge heels remains.

Kev Words: EFFLUENTS AND WASTES - highlevel waste, radioactivesludge, waste storage tanks, sludge retrieval, 200 Areas

\section{R-6}

Raymond Kaizer Engineers (RKE). 1982. Qutfall Diffuser Conceptual Design. Hanford Generating Plant. Final Report. Prepared for Washington Public Power Supply System, Richland, Washington. Irregular pages.

Abstract: Three designs of a high-velocity diffuser, to supplant the existing low-velocity diffusers on the HGP outfall line, were mathematically analyzed, physically modeled, and tested for thermal mixing. Any of the new designs would limit the maximum water temperature to $77^{\circ} \mathrm{F}$ at the upper boundary of the bottom third of the river. However, Design 3 would disperse condenser cooling water in the river best, and also minimize torsional forces on the outfall induced by the multiple diffuser jets. Designs 2 and 3 would each cost an estimated $\$ 1,141,000$; design 1 would cost about $7 \%$ more. Design 3 was recommended for further study. 
Kev Words: HANFORD SITE - cooling water discharge, HGP, outfall diffuser design

\section{R-7}

Rice, D. G. 1980. Overview of Cultural Resources on the Hanford Reservation in South Central Washington State. Report to U.S. Department of Energy, Richland Operations Office, Richland, Washington. $130 \mathrm{p}$.

Contents: This report reviews 13 years of archaeological inventory and site evaluation work conducted by the author on the Hanford Site. Results of the effort include: 1) an inventory of 115 archaeological sites, 2) identification of buildings and structures of possible historical significance, 3 ) a list of nine archaeological and historic districts and sites on the National Register of Historic Places (one other district pending), 4) identification of sites of Importance to local Native Americans, 5) the subsurface evaluation of one historic site and two prehistoric sites, and recovery of one site, and 5) recommendations for further archaeological inventory and site evaluation work.

Kev Words: SOCIOECONOMICS - archaeological inventory, archaeological resources, archaeological sites, recommendations

\section{R-8}

Richardson, G. L. 1980. Deferred Processing of Hanford Hieh-Level Wastes. HFEL-TME-80-48, Hanford Engineering DevelopmentLaboratory, Richland, Washington. 160 p., App. A through D.

Abstract: Preliminary costs, resource commitments, and potential health effects were determined for deferred disposal of high-level, in-tank wastes at Hanford. Implementation costs and potential radiological health effects to the public decrease with time for the first 200 years of deferral, but tend to level off after about 200 to 300 years. A deferral of 250 years was selected for detailed examination. At this time, gamma activity will have decreased to a point where the waste can be treated as a low-gamma-level TRU waste. Four general alternatives were examined: 1) near-term geologic disposal of stored waste,
2) deferred geologic disposal of in-tank waste, 3) insitu disposal of in-tank waste, and 4) continue present action for stored waste.

Kev Words: HANFORD SITE - alternativesassessment, high-level radioactive wastes, planning document, waste storage tanks

\section{R-9}

Richmond, W. G. 1987. "Waste Characterization Program Development for Hanford Grout Disposal." In Waste Manaeement '87. Proceedings of the Svmposium on Waste Management. Vol. 3 LowLevel Wastes, ed. R. G. Post, pp. 539-543. University of Arizona Press, Tucson, Arizona.

Ahstract: Disposal of the low-level fraction of liquid double-shell tank waste in cementitious grout requires characterization of the waste to allow development of grout formulas and to support environmentaldocuments. This report describes the Hanford grout disposal program plan. Discussion includes the methods for plan development, ident cation of waste species requiring analysis, the lower limits of detection for these waste species, and the reasons for the limits. The use of predictor analysis for determining the information needed to evaluate the environmental impact of disposal action is discussed.

Kev Words: EFFLUENTS AND WASTES - grout technology, Hanford Site, radioactive waste management, remedial plans, waste disposal/treatment

\section{R-10}

Rickard, W. R. 1985. "Biomass and Shoot Production in an Undisturbed Sagebrush-Bunchgrass Community." Northwest Sci, 59:126-133.

Abstract: Total biomass in an undisturbed sagebrushbunchgrass community on the Hanford Site was 1572 $\mathrm{g}$ dry weight $/ \mathrm{m}^{2}$ with $422 \mathrm{~g}$ aboveground and $1150 \mathrm{~g}$ belowground. Sagebrush contributed $127 \mathrm{~g}$. Grass crowns, litter, and standing dead herbaceous plants contributed $233 \mathrm{~g}$, and the living shoots of herbs contributed $62 \mathrm{~g} / \mathrm{m}^{2}$. Twenty-five percent of the belowground biomass was in the upper decimeter of 
soil, and $41 \%$ was in the surface $2 \mathrm{dm}$. Over a 4-year period, herbaceous shoot production averaged $62 \mathrm{~g} /$ $\mathrm{m}^{2}$ with a range of 50 to $69 \mathrm{~g}$. Sagebrush produced an estimated $10 \mathrm{~g} / \mathrm{m}^{2} /$ year. Production of herbaceous shoots and shrubs in the sagebrush-bunchgrass community was at the low end of scales cited in the literature for other semi-arid grassland communities in the western United States.

Kev Words: TERRESTRIAL ECOLOGY - big sagebrush, bluebunch wheatgrass, community production, phytomass, shrub-steppeecosystem

\section{R-11}

Rickard, W. H. 1985. "Experimental Cattle Grazing in a Relatively Undisturbed Shrubsteppe Community." Northwest Sci, 59:66-72.

Abstract: Yearling Hereford steers were grazed for $\mathbf{6}$ to 8 weeks in April and May for $\mathbf{3}$ consecutive years on 9-ha pastures in shrub steppe communities of sagebrush and bunchgrass in a relatively undisturbed condition. Steers showed a grazing preference for Cusick bluegrass and hawk's beard. Grazing over 3 years diminished the amount of standing dead grass by $50 \%$, but did not significantly alter production of herbaceous shoots in the fourth year after grazing was discontinued. Steers gained an average of $24 \mathrm{~kg}$ per hectare during the grazing season, with an average weight gain of $0.63 \mathrm{~kg} /$ day/animal. Trampling caused the most obvious and persistent damage, particularly where steers gathered near fence comers and watering troughs. Trampled ground was promptly colonized by alien, annual plants, especially cheatgrass and tumble mustard.

Key Words: TERRESTRIAL ECOLOGY - big sagebrush, bluebunch wheatgrass, community production, effects of grazing, forage plants, shrubsteppe ecosystem

\section{R-12}

Rickard, W. H. 1985. "Shoot Production and Mineral Nutrient Assimilation in Cheatgrass Communities." Northwest Sci, 59:169-179.

Abstract: Shoot production at peak yields in cheatgrass communities during the 1968-1969 growing season averaged 212 and $370 \mathrm{~g} / \mathrm{m}^{2}$ dry weight at elevations of $\mathbf{5 2 0}$ mand $\mathbf{3 2 3} \mathrm{m}$, respectively, on the Hanford Site. Litter (dead plants) at the high elevation site averaged $362 \mathrm{~g} / \mathrm{m}^{2}$ compared to $225 \mathrm{~g}$ at the low elevation site. The higher site also had more precipitationand more soil water. Shoots and litter from the high elevation site had less assimilated nitrogen, suggesting that the availability of nitrogen in the root zone constrained shoot production.

Kev Words: TERRESTRIALECOLOGY - cheatgrass, community production, effects of elevation, shrub-steppeecosystem

\section{R-13}

Rickard, W. H. 1988. Natural Vegetation at the Proposed Reference Repository Location in Southeastern Washington. PNL-6402, Pacific Northwest Laboratory, Richland, Washington. 22 p.

Abstract: This is one of seven Environmental Topical Reports produced by BWIP before the effort ended in late 1987. The reports provide environmental information about Hanford, then a possible site for the nation's first geologic repository for radioactive wastes. Natural vegetation near the proposed exploratory shaft was initially characterized. The dominant shrubs in five study plots were sagebrush and spiny hopsage, while the dominant herbs were cheatgrass and Sandberg's bluegrass. Both sagebrush and spiny hopsage were vulnerable to burning and damage by off-road vehicles, but sagebrush could reproduce much better via seedlings than hopsage. Differences in groundcover between cheatgrass, an alien plant, and Sandberg's bluegrass were probably caused by differences in soil properties rather than by past human disturbances. Both native and alien plants protected the soil against wind erosion, and some provided food for wildlife.

Kev Words: TERRESTRIALECOLOGY - BWIP site, effects of burning, effects of off-road vehicles, plant community, species composition,200 Areas

\section{R-14}

Rickard, W. H., and C. E. Cushing. 1982. "Recovery of Streamside Woody Vegetation After Exclusion of Livestock Grazing." J. Ranee Manage. 35:360361. 
Abstract: Livestock grazing was prohibited along a small, perennial desert stream (Rattlesnake Springs on the Hanford Site) in 1962. Grazing had previously destroyed vegetation along the stream. Woody vegetation (primarily willows) was reestablished in the riparian zone within 10 years.

Kev Words: TERRESTRIAL ECOLOGY - effects of grazing, Rattlesnake Springs, riparian plants, recovery process, willows

\section{R-15}

Rickard, W. H., and R. E. Fitzner. 1985. "Mineral Content of Canada Goose Eggs and Implications for Environmental Surveillance Along the Columbia River." Northwest Sci. 59:28-32.

Abstract Historically, the main stem of the Columbia River has been relatively free from industrial releases of mineral elements. Eggs from deserted Canada goose nests on islands in the Hanford Reach were chemically analyzed for an array of essential mineral nutrients and for potentially toxic elements. Eggs are useful for environmental monitoring because eggs are available each year and no birds are killed. Elemental compositions of goose eggs from five islands in the Hanford Reach were tabulated. Phosphorus, sulfur, and sodium were the most abundant elements, followed by calcium, potassium, and magnesium.

Kev Words: TERRESTRIALECOLOGY - biomonitoring, Canada geese, egg composition, Hanford Reach, trace elements (eggs)

\section{R-16}

Rickard, W. H., R. E. Fitzner, and C. E. Cushing. 1981. "Biological Colonization of an Industrial Pond: Status After Two Decades." Environ. Conserv, 8:241-247.

Abstract: The biological status of a 20-year-old, isolated, man-made pond (Gable Mt. Pond) is described. The pond, established in 1957 in the dry sagebrush area of eastern Washington, is now colonized by bullrushes, cattails, and numerous algae. Migratory waterfowl use the pond for feeding and nesting. Mule deer, coyotes, and raccoons visit the pond. However, there are no muskrats, beavers, turtles, or garter snakes, apparently because the pond is isolated with no connecting waterways. Some aquatic arthropods, crustaceans, and snails are now present. The pond contains low levels of industrialderived radionuclides, especially ${ }^{137} \mathrm{Cs}$. Some societal concerns and research potentials are discussed.

Kev Words: TERRESTRIAL ECOLOGY - animal documentation. Gable Mt. Pond, habitat use, plant documentation,riparian plants

\section{R-17}

Rickard, W. H., and T. R. Garland. 1983. "Trace Element Content of Leaves of Desert Shrubs in South-Central Washington." Northwest Sci. 57:5761.

Abstract: Analysis of leaves of desert shrubs showed strong differences in macroelements according to species and location on the ALE Reserve. Halophytes were characterized by high levels of potassium, chlorine, bromine, manganese, and sodium; and glycophyes by high levels of calcium and magnesium. However, trace element content was not significantly different. Trace elements in leaves of big sagebrush from Wyoming and the ALE Reserve did not differ greatly. Natural leaf fall collectionscan be used to monitor changes in trace elements resulting from environmental disturbances.

Kev Words: TERRESTRIAL ECOLOGY - ALE Reserve, big sagebrush, plant community, trace elements (in leaves),

\section{$\mathrm{R}-18$}

Rickard, W. H., W. C. Hanson, and R. E. Fitzner. 1982. "The Non-Fisheries Biological Resources of the Hanford Reach of the Columbia River." Northwest Sci. 56:62-76.

Abstract: The Hanford Reach is the only undammed section of the mainstem Columbia River in the United States. Restricted access policies for 35 years have made the Hanford Reach a refuge for wildlife. Protection has been especially important for bald eagle, mule deer, coyote, and resident Canada goose. Islands are important for nesting geese and fawning deer. Coyotes are predators on nesting geese and mule deer fauns, and salmon carcasses are a winter 
food for bald eagles. Riparian plant communities along the Hanford Reach have changed in response to water level fluctuations from generating hydroelectric power upstream. No studies have been conducted to documenteffects on shoreline plant communities.

Kev Words: TERRESTRIALECOLOGY - animal documentation, effect of public exclusion, effect of water-level fluctuations, Hanford Reach, habitat use, overview

\section{R-19}

Rickard, W. H., and M. C. McShane. 1984. "Demise of Spiny Hopsage Following Summer Wildfire: an Authentic Record." Northwest Sci. 58:282-285.

Abstract: Spiny hopsage growing in a plant community dominated by greasewood was destroyed by summer wildfire on the Hanford Site. Greasewood shrubs sprouted the first summer after the burn and about half of its preburn canopy was restored by April of the second spring. Spiny hopsage did not sprout, apparently because of stress imposed by growing in an alkaline-sodic rooting substrate.

Key Words: TERRESTRIAL ECOLOGY - effects of wildfire, spiny hopsage, greasewood, species composition

\section{R-20}

Rickard, W. H., and M. C. McShane. 1984. "Iodine in Terrestrial Wildlife on the U.S. Department of Energy's Hanford Site in South Central Washington." Environ. Monitor. Assess. 4:379-388.

Abstract: Iodine-129 has been released to the air in controlled amounts from chemical separations facilities on the Hanford Site. Small amounts of ${ }^{129} \mathrm{I}$ have accumulated in surface soils, particularly near the separation facilities, and in the thyroid gland of mule deer on the site. Stable iodine occurs in low concentrations in onsite soils, and is not avidly accumulated by wild plants. Soils at high elevations contain more ${ }^{129} \mathrm{I}$ than soils at low elevation. Thyroids of mule deer contain more stable iodine than thyroids of black-tailed jackrabbits. Stable iodine in the jackrabbits varied with season, reaching maximum in summer. Iodine-131 has not been released from chemical separation facilities at Hanford for over 10 years. Because of the radionuclides short half-life, evidence of these releases has disappeared. Jackrabbits could be used as biological indicators of ${ }^{131} \mathrm{I}$ if the chemical separation facilities restart.

Kev Words: RADIOACTIVITY - assessment, atmospheric dispersion, biomonitoring, Hanford Site, onsite operations, iodine-129, iodine-131, surface soil

\section{R-21}

Rickard, W. H., and L. E. Rogers. 1983. "Industrial Land Use and the Conservation of Native Biota in the Shrub-Steppe Region of Western North America." Environ. Conserv 10:205-211.

Abstract: Bitterbrush-sagebrush/cheatgrass communities cover about $300 \mathrm{~km}^{2}$ on the Hanford Site. Before 1943, part of the land was used for irrigated agriculture and the remainder for livestock grazing. In 1943, public use was terminated and residents were relocated. Since that time, the land has been used primarily for nuclear energy developmentand other industrial purposes. Access is restricted and shooting wildlife is prohibited. Facilities at Hanford consist of a few large buildings, which are widely separated by tracts of undeveloped land supporting native plants and animals. The undeveloped land provides habitat for species not adapted to intensive irrigated agriculture - a potential use of almost all arid land covered by bitterbrush-sagebrushcommunities. The primary disturbance is wildfire, which destroys vegetative groundcover. Bitterbrush and sagebrush are slow to recolonize bums, but other species are less affected and can recover quickly. Restricted use of the land enables ecological studies of natural revegetative processes on abandoned or burned fields.

Kev Words: TERRESTRIALECOLOGY - effect of public exclusion, Hanford Site, plant colonization, reclamation, shrub-steppeecosystem 
Rickard, W.H., L. E. Rogers, B. E. Vaughan, and S. F. Liebetrau (eds.). 1988. Shrub-Stepoe,Balance and Change in a Semi-Terrestrial Ecosvstem. Elsevier Science Publishers, New York. 272 p.

Contents: This book reviews ecological conditions and ecosystem functions on the Hanford Site, an area of shrub-steppe covering about $570 \mathrm{mi}^{2}$ in southeastem Washington. Chapters by contributing authors cover the following topics: 1) an introduction to shrub-steppe lands, 2) climate of the Hanford Site, 3) carbon and mineral cycling processes of soils, 4 ) water balance, 5) springs and streams, 6) characteristics and responses of plant communities, 7) habitats and population responses of terrestrial animals, and 8) a theoretical perspective on ecosystem disturbance and recovery.

Kev Words: TERRESTRIAL ECOLOGY • ecological relations, Hanford Site, overview, shrub-steppe ecosystem

\section{R-23}

Rickard, W. H., and R. H. Sauer. 1982. "Self-Revegetation of Disturbed Ground in the Deserts of Nevada and Washington." Northwest Sci. 56:41-47.

Abstract: Plant cover established without purposeful soil preparation or seeding was measured on ground disturbed by plowing in Washington (Hanford Site) and by aboveground nuclear explosions in Nevada. After three decades in Washington and two decades in Nevada, fewer plant species were self-established on the disturbed ground than on nearby undisturbed ground. Alien annual plants were dominant on disturbed ground: cheatgrass on abandoned fields in Washington and filaree on the test site in Nevada. Perennial grasses and shrubs seemed more successful as invaders in Nevada than in Washington, primarily because of the superior competitive ability of cheatgrass in Washington.

Kev Words: TERRESTRIALECOLOGY - cheatgrass, effects of plowing, filaree, plant colonization, recovery, shrub-steppe ecosystem
Rickard, W. H., and R. H. Sauer. 1982. "Primary Production and Canopy Cover in Bitterbrush-Cheatgrass Communities." Northwest Sci. 56:250-256.

Abstract: Aboveground grass and forb production averaged $126 \mathrm{~g} / \mathrm{m}^{2} / \mathrm{yr}$, and ranged between 10 and $195 \mathrm{~g} / \mathrm{m}^{2}$ over a 4-year period, 1975 through 1978. Low production occurred in 1977, a year of extreme drought. Production was not significantly different between burned and unburned sites 5 years after the 1970 burn. Canopy cover and species composition was similar on burned and unburned sites except for two shrubs, bitterbrush and big sagebrush. Both were killed by burning and apparently did not invade burned areas as seedlings or by sprouting. Some implications of effects of burning on mule deer are discussed.

Kev Words: TERRESTRIAL ECOLOGY - big sagebrush, bitterbrush, community production, effects of burning, effects of drought, Hanford Site, mule deer

\section{R-25}

Rickard, W. H, and C. A. Schuler. 1988. Descriotions of Plant Communities at the Proposed Reference Renositorv Location and Implications for Reclamation of Disturbed Ground. PNL-6494, Pacific Northwest Laboratory, Richland, Washington. $21 \mathrm{p}$.

Abstract This is one of seven Environmental Topical Reports produced by the BWIP before effort ended in late 1987. The reports provide environmental information about Hanford, then a possible site for the nation's first geologic repository for radioactive wastes. Natural vegetation is described in Cold Creek Valley, site of the proposed reference repository. Information is given on plant species composition, canopy cover, and shrub density from study plots in three types of habitat: sagebrush1 Sandberg's bluegrass, spiny hopsage/Sandberg's bluegrass, and sagebrush/needle-and-thread grass. Cold Creek Valley has relatively few plant species. The most abundant shrubs were sagebrush and spiny hopsage. The most abundant herbs were cheatgrass, Sandberg's bluegrass, and needle-and-thread grass. 
In seven plots, not recently burned, canopy cover ranged between $7.4 \%$ and $33 \%$ for shrubs and $18 \%$ and $41 \%$ for herbs. Recently burned plots had more herbaceous cover than adjacent unburned plots. Amounts of living herb cover were less in 1987 than in 1986, probably because of less precipitation during the growing season. Even though no livestock have grazed in Cold Creek Valley for 40 years, exotic cheatgrass generally provided more canopy than native perennial grasses. However, cheatgrass was less abundant among a few good stands of Sandberg's bluegrass. Reclamation should include the use of native plants well-adapted to the climate and soils of Cold Creek Valley, and vegetation beneficial to native wildlife.

Kev Words: TERRESTRIALECOLOGY - BWIP site, Cold Creek Valley, community production, effects of burning, effects of grazing, plant communities, recovery process, revegetation

\section{$\mathrm{R}-26$}

Rickard, W. H., and J. L. Warren. 1981. "Canopy Cover and Phytomass Comparisons of Steep Slopes Planted to Cheatgrass." Northwest Sci. 5:40-43.

Abstract: Steep slopes on an artificially formed earth mound (on Hanford Site) were seeded with cheatgrass in the autumn of 1971 and left unattended. In 1978, the north-facing slope provided more canopy cover and more living phytomass than did the south-facing slope. Live, aboveground phytomass was $830 \mathrm{~g} / \mathrm{m}^{2}$ on the north-facing slope and $163 \mathrm{~g} / \mathrm{m}^{2}$ on the south-facing slope. Increased primary production on the north-facing slope was attributed to temperature and water relationships, rather than to soil differences, because the mound was a homogeneous mix of soil from a common source.

Kev Words: TERRESTRIALECOLOGY - community production, cheatgrass, effects of slope, reclamation

\section{R-27}

Rickard, W. H., and J. L. Warren. 1981. "Response of Steppe Shrubs to the 1977 Drought." Northwest Sci. 55:108-112.
Abstract: Litterfall collecting is a non-destructive and efficient way to monitor leaf growth of steppe shrubs over extended periods of time. On the Hanford Site, drought accompanied the 1977 growing season. Shrubs responded by producing few leaves, resulting in less litterfall. Spiny hopsage did not produce leaves in some areas. When the drought was broken in 1978, sagebrush, bitterbrush, spiny hopsage, and greasewood produced as much or more litterfall than they did in the 1976 growing season.

Kev Words: TERRESTRIALECOLOGY - community production, effects of drought, Hanford Site, litterfall

\section{R-28}

Rickard, W. H., and D. G. Watson. 1985. "Four Decades of Environmental Change and Their Influence Upon Native Wildlife and Fish on the MidColumbia River, Washington, U.S.A." Environ. Conserv 12:241-248.

Abstract: The Hanford Reach of the Columbia River, and much of the adjacent land, has been changed by human activities over the past 40 years. Construction of hydroelectric dams and expansion of irrigated agriculture have been major disturbances. However, the Hanford Site is still mostly undeveloped land that supports native vegetation. Restricted land use has favored populations of wildlife (mule deer, Canada geese, great blue heron) that use riverine habitats along the Columbia River. A spawning population of chinook salmon in the Hanford Reach has increased over the last 10 years, attracting increasing numbers of wintering bald eagles. After the plutonium production reactors on the Hanford Site shut down (in early 1971), the short-lived radionuclides ${ }^{32} \mathrm{P}$ and ${ }^{65} \mathrm{Zn}$ disappeared through radiodecay and downstream transport. In the future, chemicals may appear in the Hanford Reach from industrial development and increased agricultural use above Hanford.

Kev Words: HANFORD SITE - animal populations, environmental assessment, Hanford Reach, overview, wildlife use 
Riley, R. G., R. M. Bean, R. E. Fitzner, D. A. Neitzel, and W. H. Rickard. 1986. A Preliminary Survey of Polvchlorinated Biohenvls (PCBs) in Aquatic Hahitats and Great Blue Herons on the Hanford Site. PNL-5685, Pacific Northwest Laboratory, Richland, Washington. 20 p., App. A through E.

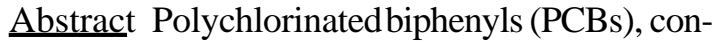
stituents of insulating fluids in electrical transformers and capacitors, were identified from five locations on the Hanford Site: Gable Mt. Pond, B Pond, West Pond, White Bluffs Slough on the Hanford Reach, and a pond on the Wahluke Slope. These waters were within the foraging range of great blue herons that nest at Hanford. Of the locations containing $\mathrm{PCBs}$, concentrationswere somewhat over $1 \mathrm{ng} / \mathrm{L}$, but less than $20 \mathrm{ng} / \mathrm{L}$, and equal to or less than concentrationsreported for other freshwater regions in the United States. The PCBs in sediments and fish closely resembled the chromatographic profile of Aroclor 1260. The highest PCB concentrations were in the upper $5 \mathrm{~cm}$ of sediments at Gable Mt. Pond and B Pond (up to $230 \mathrm{ppb}$ ) and in the fat of fish from Gable Mt. Pond and White Bluffs Slough (up to $4.7 \mathrm{ppm}$ ). Concentrations of PCBs in sediments were 10 to 100 times lower than those in soils and sediments from other areas of the nation. Fat in great blue herons contained PCBs at 3.6 to $10.6 \mathrm{ppm}$, while fat from great blue herons in other parts of the Pacific Northwest (analyzed in this study) ranged from 0.6 to $15.6 \mathrm{ppm}$.

Key Words: HANFORD SITE - environmental monitoring, polychlorinated biphenyls, pond ecosystems, pond sediments, 200 Areas

\section{R-30}

Riley, R. G., L. A. Prohammer, D. A. Neitzel, R. M. Bean, and J. M. Thomas. Distribution of Polychlorinated Biphenvls (PCBs) in Surface Sediments of Gable Mountain Pond. PNL-5625, Pacific Northwest Laboratory, Richland, Washington. 20 p., App. A through D.

Abstract: Sediment samples were taken and analyzed in June 1984 to determine concentration and distribution of polychlorinated biphenyls in Gable Mt. Pond. The information was needed to support proper stabilization and/or waste management decisions for the pond based on current regulationsfor disposal of PCB-containing wastes. All samples, with one exception, contained the specific PCB Aroclor 1260, a constituent of the insulating fluid used in electric transformers. The highest concentrations in Gable Mt. Pond were next to the outlet pipe. Distribution of PCBs was consistent with the hypothesis that they entered primarily from the inlet pipe and spread through the pond in a roughly westerly direction. Concentrations of Aroclor 1260 ranged from 2 to 148 $\mathrm{ppb}$, which was roughly 2 to 4 orders of magnitude below the regulated upper concentration limit (50 ppm) for the disposal of PCB-contaminated waste.

Kev Words: I-IANFORDSITE - Gable Mt. Pond, polychlorinated biphenyls, pond sediment, 200 Areas

\section{R-31}

Robertson, D. E., A. P. Toste, K. H. Abel, and R. L. Brodzinski. 1983. Radionuclide Migration in Groundwater. Annual Progress Report for 1982. NUREG/CR-3554 (PNL-4773), U.S. Nuclear Regulatory Commission, Washington, D.C. 70 p.

Abstract: Research continues at a low-level waste disposal site to characterize the physicochemical species of radionuclides migrating in ground water. A basin and trench (100 Area, Hanford Site) retains most of the radionuclides, but trace amounts of a few exist in soluble, mobile chemical forms that emerge 260 m away in seepage springs. During FY 1982, three wells were installed 30,46 , and $73 \mathrm{~m}$ from the trench. Soil cores from these wells contained very low levels of radioactivity,indicating the mobile forms of radionuclides did not readily absorb to onsite soils once they had passed from the trench.

Ground-water samples were analyzed in January and February 1983. Particulate and cationic forms of radionuclides were retained in the soil near the trench. Anionic $\left({ }^{60} \mathrm{Co},{ }^{99} \mathrm{Mo},{ }^{99} \mathrm{mc},{ }^{103-106} \mathrm{Ru}\right.$, and $\left.{ }^{131} \mathrm{I}\right)$ and nonionic forms $\left({ }^{125} \mathrm{Sb}\right)$ migrated to the springs. During January sampling, anionic forms of ${ }^{54} \mathrm{Mn}$, ${ }^{59} \mathrm{Fe}$, and ${ }^{95} \mathrm{Nb}$ migrated in ground water only as far as the first well. Cesium-137, ${ }^{140} \mathrm{La},{ }^{144} \mathrm{Ce}$, and ${ }^{154} \mathrm{Eu}$ were never detected in water from wells or springs.

A major fraction (49 to 57\%) of the total ${ }^{131} \mathrm{I}$ in trench, well, and spring water occurred as a presumably soluble organic species that behaved like an 
anion and appeared quite mobile. Inorganic iodide (I-) accounted for 42 to $48 \%$ of total ${ }^{131} \mathrm{I}$, and iodate $\left(\mathrm{IO}_{3}{ }^{-}\right)$only 1 to $3 \%$. Nickel-36, a long-lived radionuclide, was barely detectable in spring water and appeared to occur mainly in nonionic form. Tritium concentrations in trench, well, and spring waters $(16,000$ to $45,000 \mathrm{pCi} / \mathrm{L})$ were elevated well above ambient ground water levels and served as a very useful tracer of trench water. Trench, well, and spring waters were well oxygenated and contained low concentrations of dissolved organic matter. Organic materials were measured in trench sediments because organic complexes may increase the mobility of radionuclides in ground water, but their effect was not determined.

Kev Words: RADIOACTIVITY - behavior in soil, ground-water transport, physicochemical properties, radionuclides, shoreline springs, 100 Areas

\section{R-32}

Rockwell Hanford Operations. 1980. Technical Status Report on Environmental Aspects of LongTerm Management of Hieh-Level Defense Waste at the Hanford Site. RHO-LD-139, Rockwell Hanford Operations, Richland, Washington. Irregular pages.

Contents: A large inventory of radioactive HLW, the residue of processing spent reactor fuel to recover plutonium and uranium, is stored in underground tanks and metal capsules in water basins on the Hanford Site. To avoid threat to public health and safety, HLW must be isolated from the biosphere for thousands of years. This report evaluates the environmental impacts of four alternatives for longterm management of HLW at Hanford: 1) near-term geologic disposal of stored waste, 2) deferred geologic disposal of in-tank waste, 3 ) in situ disposal of in-tank waste, and 4) continue present action for stored waste. The environmental impacts of the four alternatives were considered to be small relative to natural radiation from natural sources in the atmosphere and earth. Eventual disposal may combine features of the four considered alternatives, i.e., placing most of the HLW in a geologic repository and leaving the balance in situ.

Kev Words: EFFLUENTS AND WASTES - alternatives assessment, high-level waste, radioactive waste management, remedial assessment, 200 Areas
Rockwell Hanford Operations. 1980. Technical Asnects of Long-Term Management Alternativesfor High-LevelDefense Waste at the Hanford Site. RHO-LD-141, Rockwell Hanford Operations, Richland, Washington. Irregular pages, App. A through $\mathrm{C}$.

Abstract: Activities at Hanford since 1944 have left a large inventory of radioactive HLW, the residue from processing spent reactor fuel to recover plutonium and uranium. This report provides information on technical aspects of nine alternatives for long-term management of HLW (six for in-tank waste, and three for encapsulated waste).

For in-tank waste: 1) Continued storage in tanks for an indefinite period, either with or without engineered barriers, is far less costly than any alternative that requires waste processing and disposal elsewhere. 2) Permanently committed land, personnel, energy, and most material requirements are higher for geological disposal than for in situ disposal or near-surfacestorage. 3) Personnel requirements, and most energy and material requirements, are less (lower) for alternatives that include reduction of waste to be placed in a geologic repository. 4) Personnel requirements are higher for onsite geologic disposal than for offsite geologic disposal. For encapsulated waste: 1) Continued storage in an onsite, near-surface facility is more costly than disposal in a geological repository because of the cost of surveillance for 250 years. 2) Personnel requirements and most energy requirements are lower for geological disposal alternatives than for continued disposal in an onsite, near-surfacefacility.

To narrow the scope of the technology development program: 1) Efforts for a geological repository at Hanford should focus on determining the acceptability of an onsite geologic repository, which is currently in progress as part of the National Waste Terminal Storage Program. 2) Development efforts for near-term disposal should focus on processes that reduce the volume of waste to place in a repository. 3) R \& D effort should emphasize areas relating to in situ, near-surface, disposal of tank waste.

Kev Words: EFFLUENTS AND WASTES - alternatives assessment, high-level wastes, radioactive waste, management, remedial assessment, 200 Areas 
Rockwell Hanford Operations. 1985. Hanford Defense Waste Disnosal Alternatives: Engineering Support Data from the Hanford Defense Waste Environmental Impact Statement. RHO-RE-ST-30 P, Rockwell Hanford Operations, Richland, Washington. Irregular pages, App. A through E.

Contents: This document provides the engineering bases for developing the Hanford Defense Waste (HDW) - Evironmental Impact Statement. Four waste disposal alternatives are identified: 1) geologic disposal, 2) in-place stabilization and disposal, 3) continued storage (no disposal action), and 4) the reference alternative. Six waste types are identified for each disposal alternative - existing tank waste, TRU-contaminated soil sites (cribs and reverse wells), pre-1970 TRU buried solid waste sites, retrievably stored and newly generated solid TRU waste, strontium and cesium capsules, and future tank waste. Disposal alternatives are presented for each waste type. Data regarding structures, site locations, and inventories for each waste type are provided, and various technologies that might be applied to implement the disposal alternatives are described. Data associated with the resulting impacts (resources consumed, manpower used, emissions, and costs) are tabulated according to a waste class/ alternative matrix.

Kev Words: EFFLUENTS AND WASTES - alternatives assessment, Hanford Site, high-level waste, radioactive waste management, remedial assessment, transuranic wastes, waste disposal/treatment

\section{R-35}

Rockwell Hanford Operations. 1986. Hanford Site Transuranic Waste Inventory Work Off Plan. RHOWM-PL-14 P, Rockwell Hanford Operations, Richland, Washington.

Abstract: A plan is presented for permanent disposal of all TRU waste on the Hanford Site, with emphasis on strategies and schedules for shipping retrievably stored and newly generated solid wastes to a waste isolation pilot plant. These plans are consistent with reference disposal plans described in the Interim Hanford Waste Management Plan and, thus, are preliminary. Contract-handled TRU waste $(<200$ $\mathrm{mrem} / \mathrm{hr}$ surface exposure) will be retrieved and transloaded to a contract-handled, waste receiving and processing facility, planned to begin operations in FY 1994. The waste will be received, examined, assayed, sorted, processed as necessary', and repackaged at this facility. Shipment of processed TRU waste to the WIPP will begin in FY 1994. Some qualified TRU waste is now being stored in the TRU storage and assay facility, and will be shipped beginning in 1989.

\section{Kev Words: EFFLUENTS AND WASTES -} Hanford Site, radioactive waste management, remedial plans, transuranic wastes, waste retrieval/ processing

\section{R-36}

Rockwell Hanford Operations. 1986. Integrated Grout Management Plan. RHO-WM-PL-12P, Rockwell Hanford Operations, Richland, Washington. $68 \mathrm{p}$.

Contents: Activities necessary to ensure the safe, environmentally sound, cost effective, and timely operation of grout disposal of low-level, liquid radioactive wastes at the Hanford Site are described. The plan includes a discussion of grout management strategy, a brief description of the grout process, an overview of key decisions that influenced the grout disposal program, and program schedules and costs. The major element is the Integrated Grout Technical Plan (Chapter 3.0). which details specific activities remaining in four areas - regulatory, technology, design and construction, and operational readiness.

\section{Kev Words: EFFLUENTS AND WASTES -} Hanford Site, integrated grout management plan, low-level wastes, remedial plans, radioactive waste management

\section{R-37}

Rockwell Hanford Operations. 1987. Hanford Site Implementation Plan for Buried. Transuranic-Contaminated Waste. RHO-WM-PL-15 P, Rockwell Hanford Operations, Richland, Washington. Irregular pages.

Abstract: Since the DOE's Defense Waste Management Plan was issued in 1983, an extensive data base has been developed for all high-level and TRU waste 
at the Hanford Site. Thirty-three buried sites were identified as possibly having TRU-classified waste. Inventory reports and process flowsheets were used to estimate the radionuclide and hazardous chemical content at these sites, and at about 370 additional sites that could be classified as low-level waste. Plans to characterize select sites suspected of containing TRU wastes to refine the inventory estimates are under way. Further effort will determine remedial actions by balancing long-term risks with costs and complying with regulations.

A recently issued draft environmentalimpact statement on disposal of defense waste on the Hanford Site looked at two alternatives: 1) retrieval, in which all 33 sites are exhumed, processed, and the TRU fraction taken to a waste isolation pilot plant; and 2) leave-in-place, in which long-term risks are mitigated by subsidence control and installation of a protective barrier and marker system. Estimated costs and duration for the retrieval alternative were $\$ 2$ billion and 13 years; for the leave-in-place alternative, $\$ 200$ million and 7 years.

Kev Words: EFFLUENTS AND WASTES - altematives assessment, Hanford Site, high-level wastes, remedial plans, radioactive waste management, transuranic wastes, waste disposal/burial sites

\section{R-38}

Rogers, L. E., and R. E. Fitzner. 1980. "Characterization of Darkling Beetles Inhabiting Radioecology Study Areas at the Hanford Site in Southcentral Washington." Northwest Sci. 54:202-206.

Abstract: Species and abundance of darkling beetles characteristic of biotic communities near energyrelated facilities on the Hanford Site were documented. A total of 7,831 beetles of 11 species were trapped at four study sites. Six species made up most of the catches. One species, Eleodes hispilabris, was consistently abundant in all study areas and at all seasons.

Kev Words: TERRESTRIALECOLOGY - community composition, darkling beetles, habitat use, relative abundance
Rogers, L. E., and K. A. Gano. 1980. " "Townsend Ground Squirrel Diets in the Shrub-Steppe of Southcentral Washington." ILRanee Mange. 33:463465.

\begin{abstract}
Microscopic study of fecal pellets from Townsend ground squirrels in the shrub steppe of southcentral Washington showed that squirrels preferred to feed on bluegrass and forbs (Descurainia pinnata and Lupinus laxiflorus). Phlox may also be favored. Bluebunch wheatgrass, six-weeks fescue, and lomatium were avoided. No significant differences were found in diets of ground squirrels from grazed and ungrazed study areas, or from the diets of male and female or adult and subadult ground squirrels.
\end{abstract}

Kev Words: TERRESTRIALECOLOGY - food and feeding, forage plants, shrub-steppeecosystem, Townsend ground squirrel

R-40

Rogers, L. E., N. E. Woodley, J. K. Sheldon, and P. A. Beedlow. 1988. "Diets of Darkling Beetles (Coleoptera: Tenebrionidae)Within a Shrub-Steppe Ecosystem." Ann.Entomol. Soc. Am. 81:782-791.

Abstract: The diets of 13 species of darkling beetles from the Hanford Site were analyzed. Food consisted of 47 species of vascular plants, including 7 grasses, 34 forbs, and 6 shrubs. Cluster analysis was used to examine the overlap in food habits among beetle species, and to separate them into five food preference groups. Partitioning of food resources may reflect niche space of these beetles.

Kev Words: TERRESTRIALECOLOGY - darkling beetles, food and feeding, shrub-steppe ecosystem

\section{R-41}

Rogers, P. M., R. Stone, and A. H. Lu. 1986. "Hydrologic Test Plans for Large-Scale, MultipleWell Tests in Support of Site Characterization at Hanford, Washington. “ In High-Level Nuclear Waste Disposal, ed. H. C. Burkholder, pp. 325-336. Battelle Press, Columbus, Ohio. 
Abstract: BWIP tests are planned to provide data for hydrogeologic characterization of the Hanford Site, a candidate site for a geologic repository for high-level nuclear wastes. Hydrogeologic characterization requires several lines of investigation, including 1) surface-based small-scale tests, 2) testing performed at depth from an exploratory shaft, 3) geochemistry investigations; 4) regional studies, and 5) multiplewell hydraulic tests. These tests will provide estimates of hydraulic values of the geologic media, chemical properties of the ground water, and hydrogeologic boundary conditions with respect to potential radionuclide transport.

Kev Words: I-IANFORD SITE - BWIP site, geohydrologic data collection, geologic repository, planning document

\section{$\mathrm{R}-42$}

Rokkan, D. J. 1984. UNC Nuclear Industries Reactor and Fuels Production Facilities 1983 Effluent Release Report. UNI-2795, UNC Nuclear Industries, Richland, Washington. $23 \mathrm{p}$.

Abstract: All significant discharges, radioactive and nonradioactive, from UNC facilities in CY 1983 were covered in this report. An evaluation of radioactive effluents released from $\mathrm{N}$ Reactor this year was completed. The annual average concentration of ${ }^{90} \mathrm{Sr}$ at the $\mathrm{N}$ Area shoreline springs was $2.3 \times 10^{-3} \mathrm{pCi} / \mathrm{L}$, which exceeded the Technical Specifications level of $2.0 \times 10^{-3}$ (based on ALARA), primarily in December 1983. However, releases of $90 \mathrm{Sr}$ were well below Federal and state maximum annual dose equivalents for drinking water (4 mrem to the whole body or organ). Calculated doses from ${ }^{90} \mathrm{Sr}$ releases were $<0.0033$ mrem to the whole body and $<0.012 \mathrm{mrem}$ to the bones for 1983. The remaining releases of "indicator radionuclides" were consistent with past years. No other Technical Specification concentration guides were exceeded.

\section{Kev Words: EFFLUENTS AND WASTES -} radiation dose estimates, effluents and emissions, environmental monitoring, $\mathrm{N}$ Reactor, $\mathrm{N}$ shoreline springs, radioactivity, radionuclides, regulatory compliance, 100 Areas'
Rokkan, D. J. 1985. UNC Nuclear Industries Reactor and Fuels Production Facilities 1984 Effluent Release Report. UNI-3284, UNC Nuclear Industries, Richland, Washington.

Abstract: All significant discharges, radioactiveand nonradioactive, from UNC facilities in CY 1984 were reported. The annual average concentration of ${ }^{90} \mathrm{Sr}$ released at $\mathrm{N}$ Springs was $3.5 \times 10^{-3} \mathrm{pCi} / \mathrm{L}$, which exceeded guidelines based on the ALARA concept of $2.0 \times 10^{-3} \mathrm{pCi} / \mathrm{L}$. Doses resulting from release of ${ }^{90} \mathrm{Sr}$ in 1984 were calculated to be $<0.0006 \mathrm{mrem}$ to the whole body and $<0.02$ to the bones. No other Technical Specification limit was exceeded. Total annual release of ${ }^{41} \mathrm{Ar}$ from the $116-\mathrm{N}$ stack decreased by $39 \%$ compared to 1983 . Release of ${ }^{131}$ I to the 1301-N and 1325-N LWDFs and from N Springs was higher than in 1983, but similar to releases in other years in which fuel failures occurred. A total of 1550 $\mathrm{Ci}$ of ${ }^{60} \mathrm{Co}$ was released to $1301-\mathrm{N}$ and $1325-\mathrm{N}$ LWDFs during 1984, a larger increase than in recent years. Other releases of radionuclides were quantitatively similar to those in recent years. Graphs are used to detail routine and unplanned releases.

Kev Words: EFFLUENTS AND WASTES radiation dose estimates, effluents and emissions, environmental monitoring, $\mathrm{N}$ Reactor, $\mathrm{N}$ shoreline springs, radioactivity, radionuclides, regulatory compliance, waste disposal sites, 100 Areas

\section{$\mathrm{R}-44$}

Rokkan, D.J. 1986. UNC Nuclear Industries Reactor and Fuels Production Facilities 1985 Effluent Release Report. UNI-3880, UNC Nuclear Industries, Richland, Washington.

Abstract: All significant discharges, radioactive and nonradioactive, from UNC facilities in CY 1985 were reported. No UNC Technical Specification limit was exceeded by any discharge. Total annual release of ${ }^{41} \mathrm{Ar}$ via the $116-\mathrm{N}$ stack decreased to $65,000 \mathrm{Ci}(12 \%$ less), because operation time of N Reactor was $23 \%$ less than in 1984. Total annual release of ${ }^{131} \mathrm{I}$ from $\mathrm{N}$ Springs increased to $5.4 \mathrm{Ci}$ (50\% more) because the old 1301-N LWDF was used while the new 1325-N LWDF was out of service. Total annual release of ${ }^{60} \mathrm{Co}$ from N Springs increased to $0.30 \mathrm{Ci}$ (3\% more), and release of ${ }^{90} \mathrm{Sr}$ increased to $8.4 \mathrm{Ci}$ (20\% more), 
compared to 1984 . Releases for nearly every identifiable radionuclide $\left({ }^{60} \mathrm{Co},{ }^{90} \mathrm{Sr},{ }^{131} \mathrm{I}\right)$ to the LWDFs were reduced, largely from an extended year-end maintenance outage of N Reactor. Releases of Unatural from the 333 Building cut-off saw stack increased to $130 \mu \mathrm{Ci}$ ( $67 \%$ more) during 1985 , but were only about average for recent releases. Graphs are used to detail routine and unplanned releases.

Kev Words: EFFLUENTS AND WASTES effluents and emissions, environmental monitoring, NReactor, $\mathrm{N}$ shoreline springs, radioactivity, radionuclides, regulatory compliance, waste disposal sites, 100 Areas

\section{$\mathrm{R}-45$}

Rokkan, D. J. 1987. UNC Nuclear Industries Reactor and Fuels Production Facilities 1986 Effluent Release Report. WHC-EP-0088, UNC Nuclear Industries, Richland, Washington.

Abstract All significant discharges, radioactive and nonradioactive, from UNC facilities in CY 1986 were reported. Results from the effluent sampling and analysis program indicated that all effluents were within UNC Technical Specification limits. Releases of ${ }^{90} \mathrm{Sr}$ from NSprings totaled 7.9 Ci for 1986 while averaging $5,900 \mathrm{pCi} / \mathrm{L}$, a $6 \%$ decrease in curies but a $31 \%$ increase in average concentration. For CY 1986, $36 \mathrm{Ci}$ of ${ }^{90} \mathrm{Sr}$ were discharged to the 1325-N LWDF, an $85 \%$ reduction from the $240 \mathrm{Ci}$ discharged in 1985 . Releases of ${ }^{131} \mathrm{I}$ and ${ }^{60} \mathrm{Co}$ from $\mathrm{N}$ Springs decreased greatly, to $0.030 \mathrm{Ci}$ (99\% less) and $0.13 \mathrm{Ci}$ (43\% less), respectively, because 1325Noperated full time. In September 1985, 1325-N replaced 1301-NLWDF, which had diminished radionuclide filtration and ion exchange capacity after 20 years of service. In 1986, releases to the air of ${ }^{41} \mathrm{Ar}$ increased $69 \%$, and ${ }^{135} \mathrm{Xe}$ increased $63 \%$. Graphs, tables, and narratives to detail routine and unplanned releases were included.

Kev Words: EFFLUENTS AND WASTES effluents and emissions, environmental monitoring, N Reactor, N shoreline springs, radioactivity, radionuclides, regulatory compliance, waste disposal sites, 100 Areas
Rokkan, D. J. 1988. Westinghouse Hanford Companv 100 Areas Environmental Releases for 1987. WHC-EP-0165, Westinghouse Hanford Company, Richland, Washington.

Abstract: This report covers airborne and liquid releases in the 100 Areas during CY 1987. All releases were within N Reactor Technical Specification limits and there were no adverse trends. Significant changes were related largely to an extended "standdown" of N Reactor (only 6.4 days of operation). All releases were less than in 1986, with one exception - hydrazine use to control corrosion in reactor piping increased by a factor of 3.9. Releases of ${ }^{90} \mathrm{Sr}$ via the N Springs totalled 2.4 Ci for 1987 while averaging $6,000 \mathrm{pCi} / \mathrm{L}$, following a $69 \%$ lower flow from the springs than in 1986. Comparing 1987 to 1986 , the cumes released decreased by $70 \%$, while the average concentration increased by $2 \%$. Fifteen curies of ${ }^{90} \mathrm{Sr}$ were discharged to the 1325-N LWDF in 1987, a $58 \%$ reduction from the $36 \mathrm{Ci}$ discharged in 1986. About 1,000 Ci of radionuclides with halflives greater than $48 \mathrm{hr}$ were discharged to the 1325 NLWDF in 1987, compared to 7,800 in 1986, an $87 \%$ decrease. Releases of ${ }^{131} \mathrm{I}$ and ${ }^{60} \mathrm{Co}$ via N Springs decreased in 1987 to $0.0043 \mathrm{Ci}$ and $0.052 \mathrm{Ci}$, respectively. Releases of ${ }^{41} \mathrm{Ar}$ and ${ }^{135} \mathrm{Xe}$ to the air were reduced $97 \%$ to $4,400 \mathrm{Ci}$, compared to $128,000 \mathrm{Ci}$ in 1986. Graphs, tables, and narratives were included to detail routine and unplanned releases.

\section{Kev Words: EFFLUENTS AND WASTES -} effluents and emissions, environmental monitoring, $\mathrm{N}$ Reactor, $\mathrm{N}$ shoreline springs, radioactivity, radionuclides, regulatory compliance, waste disposal sites, 100 Areas

\section{R-47}

Routson, R. C. 1983. Possible Weathering (Dissolution) of Basalt Dome-Filling Material in 241-TY Tank Farm Waste. RHO-HS-EV-20, Rockwell Hanford Operations, Richland, Washington. 13 p.

Abstract: Assumed dome collapse must be mitigated if disposal on radioactive waste in single-shell tanks is to be viable and environmentally sound. It has been proposed to fill the domes above the waste with crushed basalt to prevent dome collapse and possible 
release of radionuclides. Possible dissolution of crushed basalt in the interstitial liquid of the tanks was foreseen and evaluated. The basalt would likely settle slowly through the sludge to the bottom of the tanks, but this would be no problem. Based on solubility data, it was recommended that the basalt fragments should be a minimum of $1.0 \mathrm{~cm}$ in diameter. Maximum solubilities of basalt in highlevel tank interstitial solutions were estimated from the weathering of basalt at the surface, in a natural watershed, and from available thermodynamic data. Maximum solubility was estimated to be restricted to a thin rind around any basalt fragment. No significant solubility would be expected from dome filling.

Kev Words: EFFLUENTS AND WASTES - singleshell tanks, rock dome concept, rock solubility in HLW, tank integrity, 200 Areas

\section{$\mathrm{R}-48$}

Routson, R. C., G. S. Barney, and R. M. Smith. 1984. "Radionuclide Sorption on Low-Exchange Capacity Hanford Site Soils." Comm. Soil Sci. Plant Anal, 15:375-388.

Abstract: Trace distribution coefficients (Kd values) for ${ }^{137} \mathrm{Cs}$, ${ }^{85} \mathrm{Sr}$, and ${ }^{60} \mathrm{Co}$ sorption were a function of sediment type (i.e., soil) and of the solution concentration of macroions (including $\mathrm{Na}^{+}, \mathrm{K}^{\mathrm{t}}$, and $\mathrm{Ca}^{\mathrm{t}^{2}}$ ) over a wide range of concentrations. These $\mathrm{Kd}$ values provided sorption data input to a mass transport model. Four methods were evaluated for measuring the Kd value macroion function relationship for each sediment type. Precision, bias, and cost effectiveness were compared for choosing a preferred method. The preferred method, an empiricalstatistical method (Box-Behnken method), was as precise and unbiased as other methods and the most cost effective.

Kev Words: RADIOACTIVITY - adsorption, behavior in soil, cesium-137, cobalt-60, distribution coefficients, effect of trace ions, strontium- 85

\section{R-49}

Routson, R. C., G. S. Barney, C. H. Delegard, and R. M. Smith. 1987. "Trace Cobalt Sorption on 21 Sediment Types From the Hanford Site, Washington." Nuc. Chem. Waste Manage. 7:73-87.
Abstract: Sorption properties for trace cobalt $\left({ }^{60} \mathrm{Co}\right)$ were measured in soils of the 200 East and 200 West areas at Hanford. Scintillation logs of ground disposal facilities and particle size plus calcium carbonate sediment data were used to delineate 21 sediment types (i.e., soils) from five wells independently. The two methods gave good agreement. Empirical distribution coefficients $(\mathrm{Kd})$ equations were developed for trace ${ }^{60} \mathrm{Co}$ sorption in the 21 sediment types. Coefficients were internally of the same general form. However, there were marked differences between comparablecoefficients. Average $\mathrm{Kd}$ values computed for ${ }^{60} \mathrm{Co}$ were compared with $\mathrm{Kd}$ values from individual sediment types. Cobalt sorption was controlled only by calcium $\left(\mathrm{Ca}^{+2}\right)$. These data were needed to model transport of ${ }^{60} \mathrm{Co}$ in sodium, calcium, and potassium soil-water systems. Sensitivity analysis of retardation factor values for two sediment chemical systems were evaluated; these factors were compared for paired sediment types that occupy similar stratigraphic locations in the sampled wells. Values were generally within a factor of 3 of each other, within the expected range of error.

Kev Words: RADIOACTIVITY - adsorption, behavior in soil, cobalt-60, distribution coefficients, 200 Areas

\section{R-50}

Routson, R. C., G. S. Barney, and R. M. Smith. 1980. "Hanford Site Sorption Studies for the Control of Radioactive Wastes: A Review." Nuc. Technol. 54:100-106.

Abstract: Past and present sorption studies were reviewed. They evolved with time from generic to waste specific, then to empirical waste-specific and site-specific studies. Current sorption studies are site specific based on the radionuclide transport soil properties model (PERCOL). Radionuclide sorption is treated in the model by laboratory developed empirical/statistical equations that predict sorption as a function of ground-water chemistry. Average sorption equations for 21 sediment types identified in the Separations Area (200 Areas) were presented and discussed. Sixty three equations were given for statisticalanalysis of ${ }^{90} \mathrm{Sr},{ }^{137} \mathrm{Cs}$, and ${ }^{60} \mathrm{Co}$ sorption for each sediment type. 
Kev Words: RADIOACTIVITY - adsorption, behavior in soil, cesium-137, cobalt-60, PERCOL model, radionuclides, sorption equations, strontium85

\section{R-51}

Routson, R. C., G. S. Barney, R. M. Smith, C. H. Delegard, and L. Jensen. 1981. Fission-ProductSorption Parameters for Hanford 200 Area Sediment Types. RHO-ST-35, Rockwell Hanford Operations, Richland, Washington. $67 \mathrm{p}$.

Abstract: Sorption characteristics of ${ }^{85} \mathrm{Sr},{ }^{137} \mathrm{Cs}$, and ${ }^{60} \mathrm{Co}$ were examined with 21 types of soil from the 200 Areas. An empirical, statistical method developed by Box-Behnken was selected for predicting the distribution coefficient $(\mathrm{Kd})$ value to the equilibrium solution concentrations of sodium $\left(\mathrm{Na}^{+2}\right)$, calcium $\left(\mathrm{Ca}^{\mathrm{t}^{2}}\right)$, and potassium $\left(\mathrm{K}^{\mathrm{t}}\right)$. Study of 63 empirical $\mathrm{KD}$ value equations showed marked differences between comparable coefficients for the different trace ions. Average coefficient values were computed for each trace ion. Strontium sorption was controlled to a large extent by $\mathrm{Ca}^{+2}$, a lesser extent by $\mathrm{Na}^{+}$, and was independent of $\mathrm{K}^{+}$. Cesium sorption was controlled to a large extent by $\mathrm{K}^{+}$, a lesser extent by $\mathrm{Na}^{+}$, and independent of $\mathrm{Ca}^{+2}$. Cobalt sorption was controlled only by $\mathrm{Ca}^{+2}$. Ion exchange values were determined for the 21 sediment types, including cation exchange capacities; selectivity coefficients for calcium-magnesium,sodium-calcium, and sodium-potassium exchanges; and solid phase activity correlation coefficients.

Kev Words: RADIOACTIVITY - adsorption, behavior in soil, cesium-137, cobalt-60, distribution coefficients, effects of trace ions, ion exchange values, radionuclides, strontium- 85

\section{$\mathrm{R}-52$}

Routson, R. C., M. R. Fuchs, and W. R. Jordan. 1988. Recharge Estimate for the Hanford Site 200 Areas Plateau. WHC-EP-0046, Westinghouse Hanford Company, Richland, Washington. 10 p.

Abstract: Two sources of data were used to estimate recharge from natural precipitation on the 200 Areas Plateau at Hanford. Sources were 1) moisture accumulation in the 200 East closed-bottomlysimeter for
13 years, and 2) distribution of ${ }^{137} \mathrm{Cs}$ in a solid-waste trench where contaminated soil had been buried for 10 years. Moisture content of the lysimeter in 1985 was compared with its initial moisture content. Moisture had been redistributed from the top half to the bottom half of the lysimeter, but there was no detectable accumulation of moisture in the bottom of the lysimeter since 1972. Thus, the recharge rate was $0+/-0.2 \mathrm{~cm}$ over 13 years. Sampling of cesiumcontaminated soil indicated no measurable downward recharge. However, ${ }^{137} \mathrm{Cs}$ was detected above the trench, suggesting negative recharge. In summary, the recharge rate was zero or negative at two locations on the 200 Areas plateau.

Kev Words: GEOLOGY AND HYDROLOGY ground-water recharge, lysimeter data, 200 Areas

\section{R-53}

Routson, R. C., W. H. Price, D. J. Brown, and K. R. Fecht. 1980. "High-Level Radioactive Waste Leakage from the 241-T-106 Tank on the Hanford Site." Nuc. Chem. Waste Manage. 1:143-151.

Abstract: On June 8,1973, the 241-T-106 tank on the Hanford Site was confirmed as leaking. About $115,000 \mathrm{gal}$ of liquid containing $40,000 \mathrm{Ci}$ of ${ }^{137} \mathrm{Cs}$, $14,000 \mathrm{Ci}$ of ${ }^{90} \mathrm{Sr}, 6 \mathrm{Ci}$ of plutonium and americium, and $297,000 \mathrm{Ci}$ of various fission products (with halflives of less than 5 years) were released to the soil. Five years after the leak, 1) the maximum lateral extent of the $1-\mu \mathrm{Ci} / \mathrm{L}{ }^{106} \mathrm{Ru}$ concentration was about $23 \mathrm{~m}$ (75 ft) from any edge of the tank, or equivalent to about the diameter of the tank, and 2) the maximum depth of the $1-\mu \mathrm{Ci} / \mathrm{L}{ }^{10} \mathrm{Ru}$ concentration was 33 $\mathrm{m}(108 \mathrm{ft})$, or about $43 \%$ of the distance from the bottom of the tank to ground water. Modeling of vadose zone moisture and wetting frontal movement were in qualitative agreement, suggesting that no waste will enter the ground-watersystem.

Kev Words: EFFLUENTS AND WASTE - remedial assessment, radionuclides, radioactive liquids, singleshell tanks, soil percolation (in situ), tank leakage, 200 Areas 
Routson, R. C., J. B. Sission, D. Paine, and J. A. Caggiano. 1981. Proposed Siting Criteria for the Arid Shallow-Land Burial of Solid Low-Level Radioactive Waste. RHO-LD-81, Rockwell Hanford Operations, Richland, Washington. 29 p.

Contents: Criteria were proposed to exclude unacceptable sites from shallow-land burial of low-level radioactive wastes in arid climates under controlled access for 150 years. Potential transport mechanisms from shallow-land burial sites to the environment and man were listed. Currently available models were used to estimate transport by all credible chronic translocation mechanisms. Conservative site parameters for input were selected for a model on a shallow-land burial reference containment facility (RCF). These values were based on scientific and engineering judgement. Limiting radionuclide concentrations in the RCF were based on calculations of the highest concentration that would give an acceptable dose to man following each of the credible transport exposure events modeled. Parameters were found for four DOE arid or semi-arid land sites. Only one parameter at one DOE site exceeded the RCFparameter value, and this had no effect on dose to man when the climate was arid.

Kev Words: HANFORD SITE - arid-land sites, reference containment facility, environmental assessment, planning document, waste disposal

\section{S-1}

Salter, P. F., L. L. Ames, and J. E. McGarrah. 1981. The Sorotion Behavior of Selected Radionuclides on Columbia River Basalts. RHO-BWI-LD-48, Rockwell Hanford Operations, Richland, Washington. 66 p., App. A and B.

Abstract: The sorption of radionuclides on Columbia River basalts was investigated. Radionuclidedistribution coefficients, with a batch-equilibrium technique, were determined for iodine, selenium, technetium, strontium, cesium, uranium, radium, plutonium, americium, and neptunium. The effects of temperature, pressure, ground-water composition, and Eh condition on the distribution coefficient value were also investigated. In addition, sorption isotherms, describing the dependence of radionuclide sorption on radionuclide concentration were determined for cesium, strontium, radium, plutonium, and uranium under both oxidizing and reducing conditions. Under expected repository conditions (i.e., reducing, alkaline conditions), Columbia River basalts appeared capable of strongly retarding the migration of cesium, strontium, radium, and neptunium, and moderately retarding the migration of uranium, technetium, and plutonium. The basalts were not able to significantly retard migration of iodine and selenium.

Kev Words: RADIOACTIVITY - behavior in basalt, distribution coefficients, effects of pressure, radionuclides, redox potential, sorption isotherms, effects of temperature

\section{$S-2$}

Sauer, P. H. and J. E. Leder. 1985. "The Status of Yellowcress in Washington." Northwest Sci. 59:198203.

Abstract The infrequently collected yellowcress, a member of the Cruciferae family, was abundant along the Hanford Reach of the Columbia River. Yellowcress appeared seasonally in riparian areas exposed by low water. A review of herbarium specimens suggested that plants in the three known sites (southcentral Oregon; Columbia River, Washington; and Lava Beds National Monument, California) may be morphologically distinct. Yellowcress is listed as a endangered species by the Washington Natural Heritage Program, and is a candidate for federal listing.

Key Words: TERRESTRIAL ECOLOGY - endangered species, Hanford Reach, yellowcress

\section{S-3}

Schalla, R., R. L. Aaberg, D. J. Bates, J. V. M. Carlile, M. D. Freshley, T. L. Liikala, P. J. Mitchell, K. B. Olsen, and J. T. Rieger. 1988. Revised Ground-Water Monitoring Compliance Plan for the 300 Area Process Trenches. PNL-6671, Pacific Northwest Laboratory, Richland, Washington. 107 p., App. A through J.

Contents: A plan was developed to monitor ground water in the 300 Area process trenches, which have been used for disposal of water containing small 
amounts of chemicals and radionuclides since 1973. The plan revises and expands an effort initiated in June 1985 (interim permit status) when facilityspecific monitoring began at the trenches to achieve regulatory compliance. Chapters provide background information, describe interim-status work conducted to date, and detail planned expansion of the groundwater monitoring program.

Key Words: EFFLUENTS AND WASTES - ground water, monitoring program, radioactive waste, 300 Area trenches, 300 Area

\section{$S-4$}

Schalla, R., and L. A. Leonhart. 1982. "Dealing with Regional Hydrologic Data Base Limitations and Uncertainties, Case Example: the Columbia River Basalts." In Proceedings of the Symposium on the Effectiveness of Geologic Isolation of High Level Radioactive Waste, ed. D.C. Kocher, pp. 415-423. National Technical Information Service, Springfield, Virginia.

Abstract: Limits appear when assembling hydrologic data for a broad geographic area, such as the Columbia Plateau in the northwestern United States, into conceptual models of the hydrologic system. These limits are resonant in subsequent simulations of hydrologic system behavior. Limits include irregular spatial distributions of data, decreases in performance with increasing depth, uncertainties about reliability of reported data, disparities in time-dependent parameters, and lack of field verification.

Description of a regional hydrologic system first involves comprehensive data evaluation, wherein the data are classified and ranked in terms of usability. Evaluations are essential in planning future acquisition of data, and in selecting and developing models. In tum, iterative use of modeling, data refinement, and data acquisition is considered to be highly effective. The case example of describing a hydrologic system for the Columbia Plateau, as required for repository siting (e.g., BWIP), illustrates methods to determine the accuracy of certain data, compensate for data limitations, and refine data through iterative techniques. Professional objectivity must be maintained to evaluate and refine the data base.

Key Words: GEOLOGY AND HYDROLOGY geohydrologic assessment, Columbia River Plateau, computer modeling, ground water data base

\section{S-5}

Schalla, R., and 14 others. 1988. Interim Characterization Report for the 300 Area Trenches. PNL-6716, Pacific Northwest Laboratory, Richland, Washington. Irregular pages, App. A through G.

Abstract: Results of studies on the 300 Area process trenches are given. Characterization began in June 1985 , when facility-specific monitoring was initiated. The effort was part of a regulatory, ground-water monitoring compliance program for hazardous materials on the Hanford Site. This document is primarily a compendium of technical information on the 300 Area; therefore, data interpretations are limited to the most obvious. Final conclusions will not be presented until analysis of data is completed in September 1989.

Recent drilling and testing of 18 new monitoring wells in the 300 Area indicated that: 1) the Hanford formation is probably the most permeable portion of the unconfined aquifer; however, immediately below it are very permeable sand and gravels of the Ringold Formation; 2) three layers of the Ringold Formation underlie the Hanford Formation in the 300 Area; 3) the middle layer of the Ringold Formation and the Hanford formation comprise the unconfined aquifer in the 300 Area, 4) the lower member of the Ringold Formation forms the confining layer or aquitard, 5) the basal member of the Ringold Formation forms part of the uppermost confined aquifer; 6) the uppermost basalt flows are under the basal member of the Ringold Formation; and 7) definitive information on soil geochemistry and depositional history is not well understood, which precludes defining transport properties and continuity of primary hydrostratigraphic units.

The Columbia River influences direction of the ground-water flow in the 300 Area; release of process water also influences flow. Ground water flows primarily to the east and southeast, but reverses when water levels in the river remain high for a few weeks. Constituents in ground water above standards are gross alpha, gross beta, fluoride, trichloroethylene, and trans-1,2-dichloroethylene. Most of the alpha is probably uranium and radon from the process trenches. 
Key Words: EFFLUENTS AND WASTES - environmental monitoring, ground water, radioactive wastes, remedial assessment, stratigraphy, 300 Area trenches, 300 Area

\section{S-6}

Schuler, C. A., W. H. Rickard, and G. A. Sargeant. 1988. Bird Associations with Shrubsteppe Plant Communities at the Proposed Reference Repository Location in Southcentral Washington. PNL-6493, Pacific Northwest Laboratory, Richland, Washington. $32 \mathrm{p}$.

Abstract: This is one of seven Environmental Topical Reports produced by BWIP before the effort ended in late 1987. The reports provide environmental information at Hanford, then a possible site for the nation's first geologic repository for radioactive wastes. Information was obtained on seasonal use of vegetation by birds at the proposed repository comply with provisions of the Migratory Bird Treaty Act and to assess potential impacts of site characterization activities. The study was conducted on two transects from January through December 1987.

Only 38 species were counted during 82 surveys. Total bird density from March through June (nesting season) was 42.96 birds $/ \mathrm{km}^{2}$, and density over the entire year was $26.74 \mathrm{birds} / \mathrm{km}^{2}$. The western meadowlark (11.25 birds $/ \mathrm{m}^{2}$ ) and sage sparrows ( $7.76 \mathrm{bird} /$ $\mathrm{km}^{2}$ ) were the most abundant breeding birds, but breeders included the burrowing owl, mourning dove, horned lark, long-billed curlew, lark sparrow, and loggerhead shrike. Most species were present March to September. Sagebrush habitats supported more birds than cheatgrass or hopsage habitats. Sage sparrows were closely associated with sagebrush, but western meadowlarks had no strong habitat affinity. In general, bird densities were lower than those in other shrub-steppe study sites.

Key Words: TERRESTRIAL ECOLOGY - behavior, BWIP site, population density, habitat use, nongame birds, reproduction

\section{S-7}

Schultz, W. W., M. M. Beary, S. A. Gallagher, B. A. Higley, R. G. Johnston, F. M. Jungfleisch, M. J. Kupfer, R. A. Palmer, R. A. Watrous, and G. A.
Wolf. 1980. Preliminary Evaluation of Alternative Forms for Immobilization of Hanford High-Level Wastes. RHO-ST-32, Rockwell Hanford Operations, Richland, Washington. 76 p., App. A through D.

Abstract: The suitability of 19 waste forms was evaluated and compared for immobilization of Hanford salt cake, sludge, and residual liquids. Assessment was structured to address waste forms and processes covering different "leave-retrieve". long-term management alternatives for: 1) sludge plus long-lived radionuclide concentrate from salt cake and residual liquid, 2) blended waste (salt cake plus sludge plus residual liquid), 3) residual liquid, and 4) radionuclide concentrate from residual liquid.

Borosilicate glass waste forms, as marbles or monoliths, ranked among the first three choices for all Hanford high-level wastes (HLW). Supergrout concrete and bitumen, which are low-temperature waste forms, rated high for bulk immobilization of high-sodium blended wastes and residual liquids. Certain multi-barrier (e.g., coated ceramic) and ceramic (SYNBROC ceramic, tailored ceramics, and supercalcine ceramic) waste forms, along with borosilicate glass, were the most satisfactory for incorporation of sludges and associated radionuclide concentrates. The sol-gel process seems superior for manufacture of a generic ceramic waste form for fixation of Hanford sludge.

Key Words: EFFLUENTS AND WASTES - alternatives assessment, bitumen treatment, ceramic treatment, grout treatment, radioactive waste management, sol-gel process, vitrification treatment, waste disposal/treatment

\section{S-8}

Schwartz, M. N., D. J. Hoitink, O. P. Gifford, G. J. Newland, P. J. Perrault, E. R. Preston, and G. N. Reinecke. 1986. "Extreme and Persistent Temperature Anomalies at Hanford, Washington, During 1985." In Conference on Climate and Water Management - A Critical Era and Conference on the Human Consequences of 1985's Climate, pp. H3.3H3.5, American Meteorological Society, Boston, Massachusets.

Abstract: Prolonged temperature anomalies occurred in the central Columbia Basin of Washington State in 1985. Extreme cold was accompanied by unusual 
amounts of snow, resulting in dramatic changes in use of electric power and water by people in the TriCities. The overall distribution of conditions under which automobile accidents occurred in 1985 differed from previous years, and agencies responding to fire and emergencies received more calls than usual.

Key Words: AIR AND ATMOSPHERE - abnormal conditions, short-term effects, snowfall, temperature

\section{S-9}

Scott, M. J., D. B. Belzer, R. J. Nesse, R. W. Schultz, P. A. Stokowski, and D. C. Clark. 1987. The Economic and Community Impacts of Closing Hanford's N Reactor and Nuclear Materials Production Facilities. PNL-6295, Pacific Northwest Laboratory, Richland, Washington. Irregular pages, App. A and B.

Contents: Permanent closure of nuclear materials production (NMP) at the Hanford Site would have a negative economic impact on local cities and counties and the state of Washington. NMP, the largest and most important of five DOE missions at Hanford, would be lost if Hanford's N Reactor is permanently closed and not replaced. This study estimates, statewide and local, the loss of jobs, income, and purchases from the private sector caused by reactor closure. It forecasts impacts on finances of state and local governments. It describes certain local community and social impacts in the Tri-Cities (Richland, Kennewick, and Pasco) and surrounding communities.

Key Words: SOCIOECONOMICS - Benton/ Franklin counties, potential socioeconomic effects, $\mathbf{N}$ Reactor closure

\section{S-10}

Scott, M. J., and D. B. Belzer. 1988. "Hanford, the N Reactor, and Washington's Economy: The Impacts of Permanent Closure." Northwest Environ. L 4:129-155.

Abstract: The Hanford Site and its missions are economically important to Washington State. Current environmental or defense policy controversies or the reduced need for materials may end
Hanford's mission to produce nuclear materials. Closure would adversely affect other Hanford activities. Nearly 15,000 jobs would eventually be lost in the state as a result of ending nuclear materials production alone. Replacement facilities, site cleanup, and economic diversification are potential options to replace lost jobs and income, but each has significant uncertainties and limitations. Potentially, the broadest possible political and economic support might be created for individual initiatives through a "grand compromise," combining possible mitigation approaches.

Key Words: SOCIOECONOMICS - Benton/ Franklin counties, potential socioeconomic effects, $N$ Reactor closure

\section{S-Il}

Serkowski, J. A., A. G. Law, J. J. Ammerman, and A. L. Schatz. 1988. Results of Ground-Water Monitoring for Radionuclides in the Separations Area - 1987. WHC-EP-0152, Westinghouse Hanford Company, Richland, Washington. Irregular pages, App. A through D.

Contents: The Separations Area contains all liquid waste disposal facilities associated with waste processing in the 200 East and 200 West areas. Samples were taken from a network of 149 wells in 1987. Radionuclide concentrations in ground water were compared with WHC administrative control limits, based on reduction to AL.ARA, and with derived concentration guides (DCG) as directed by DOE. In general, average levels of radionuclides were similar to 1986 levels. Water table maps were produced from 200 wells. Guidelines were exceeded in some ground-water samples beneath active facilities in three cases, and beneath inactive facilities in six cases. Each case was evaluated. DCG's, while applied to onsite locations, are effective only where the public might be exposed. Maps of the nitrate and tritium plumes were included in the report.

Key Words: HANFORD SITE - environmental monitoring, ground water, radioactivity, regulatory compliance, waste disposal sites, 200 Areas 
Serne, R. J., W. J. Martin, S. B. McLaurine, S. P. Airhart, V. L. LeGore, and R. L. Treat. 1987. Laboratory Leach Tests of Phosphate/Sulfate Waste Grout and Leachate Adsorotion Tests Using Hanford Sediment. PNL-6019, Pacific Northwest Laboratory, Richland, Washington. Irregular pages, App. A through $\mathrm{C}$.

Abstracts: The DOE is supporting efforts to design and construct a facility at Hanford to immobilize and dispose of low-level radioactive waste as a solidified grout (the "Transportable Grout Facility"). Low-level liquid wastes will be mixed with blends of groutforming solids to produce a slurry. The slurry will then be pumped to near-surface disposal sites where the grout will harden into solid monoliths.

This report describes experiments that produce empirical leach rate data and leachate-sediment adsorption data for phosphate-sulfate waste (PSW) grout. Data provide input to computer codes used to forecast potential risks from the use of ground water containing leached materials. Other chemical analyses and geochemical computer code calculations used to identify mechanisms that control leach rates and adsorption potential are also discussed. Several conceptual leach models are described; the semiinfinite solid diffusion model is the most representative and yields conservative predictions.

The PSW grout was produced by mixing liquid waste with a blend of Portland Type I and Type II cement, class F fly ash, attapulgite clay, and Indian red pottery clay. With Hanford ground water as a leachate, only three stable constituents (sodium, potassium, and $\mathrm{NO}_{2}$ ) and four radionuclides $\left({ }^{85} \mathrm{Sr}\right.$, ${ }^{137} \mathrm{Cs},{ }^{60} \mathrm{Co}$, and ${ }^{54} \mathrm{Mn}$ ) leached from the grout in measurable concentrations. In general, leach rates decreased slowly with time even after $\mathbf{4 8 0}$ days. Chemical reactions appear to be lowering the leach rates of radioactive and non-radioactive constituents. No release of metals was measurable. Sections in the report describe 1) probable hydrologic and chemical processes controlling leaching and migration of materials from grout, 2) conceptual leaching and adsorption models, 3) methods and materials used in leaching and adsorption tests, 4) laboratory test results, and 5) conclusions. technology, leachate from grout, phosphate/sulfate grout, radioactive waste, remedial studies, waste disposal/treatment

\section{S-13}

Sevigny, G. J., D. N. Berger, D. H. Siemens, R. G. Baumbartel, and K. R. Shah. 1987. "Conceptual Vitrification System for the Hanford Waste Vitrification Plant." Trans, Amer. Nuclear Soc. 54:93-94.

Abstract: Technology has been developed by PNL for incorporating high-level radioactive waste at Hanford into borosilicate glass through a vitrification process. A Joule-heated, liquid-fed ceramic melter coupled to a closed canister turntable was selected as the reference vitrification system for the Hanford waste vitrification plant. The design is briefly described.

Key Words: EFFLUENTS AND WASTES - waste vitrification plant, vitrification technology, radioactive waste, waste disposal/treatment

S-14

Sewart, G. H., W. T. Farris, D. G. Huizenga, A. H. McMakin, G. P. Streile, and R. L. Treat. 1987. Long-Term Performance Assessment of Grouted Phosphate/Silicate Waste from N Reactor Operations. PNL-6152, Pacific Northwest Laboratory, Richland, Washington. Irregular pages.

Abstract: The use of grout for long-term disposal of phosphate-sulfate waste (PSW) was analyzed. PSW is a low-level liquid generated by activities associated with $\mathrm{N}$ Reactor. The waste will be mixed with dry solids, and permanently transformed to cementitious grout in sub-surface concrete vaults at the 200 East Area. Humans might be exposed to radionuclides and chemicals from the grouted waste in two scenarios: contaminated ground water and direct intrusion. In the first scenario, contaminants are released from the buried grout monoliths, then reach the Columbia River via ground water. The contaminants were assumed to leach from the monolith at a constant rate over 10,000 years. In the second scenario, intruders contact the waste inadvertently by drilling, excavating, or gardening. 
Long-term impacts from exposure of PSW grout were expressed in terms of incremental increases of chemicals in ground and surface waters, and of radiation doses. No calculated impact exceeded corresponding regulatory limits set by the state, DOE, or NRC.

Key Words: EFFLUENTS AND WASTES - grout technology, phosphate/sulfate grout, remedial assessment, radioactive waste, $\mathrm{N}$ Reactor, 200 Areas

\section{S-15}

Sheldon, J. K., and L. E. Rogers. 1984. "Seasonal and Habitat Distribution of Tenebrionid Beetles in Shrub-Steppe Communities of the Hanford Site in Eastern Washington." Environ, Entomol, 13:214220.

Abstract: The Tenebrionid beetles of the Hanford Site were studied to determine the seasonal and habitat distribution of the 15 common species occurring in six major biotic communities with reference to soil texture and vegetation type. Four species occurred in all six communities, whereas five species were restricted to one or two study sites. Three seasonal distribution patterns appeared. Two species were found only during the fall. Species in a second group occurred throughout the year. Species in a third group appeared primarily during the summer. Several species were restricted to one of three soil types: loamy sand, sandy loam, or loam.

Key Words: TERRESTRIAL ECOLOGY - habitat use, Hanford Site, seasonal distribution, Tenebrionid beetles

\section{S-16}

Simmons, C. S., C. T. Kincaid, and A. E. Reisenauer. 1986. A Simplified Model for Radioactive Waste Transport: The TRANSS Code. PNL-6029, Pacific Northwest Laboratory, Richland, Washington. Irregular pages, App. A through $C$.

Abstract: TRANSS estimates the rate of a decaying radionuclide that is subject to sorption governed by a linear isotherm. Transport is modeled as a contaminant mass passing along several streamlines representing a streamtube, which connects source release with environmental arrival zones. The contaminant arrival distribution (probability-weighted) along each streamline is represented by an analytical solution of the one-dimensional advection-dispersion equation with the constant velocity and dispersion coefficients. The model assumes that transverse dispersion in a streamtube is negligible.

Release of a contaminant is described as input information in terms of a fraction-remaining curve. An option in the code is the calculation of a fractionremaining curve based on four release models: 1) constant release, 2) release controlled by solubility, 3) release controlled by adsorption, and 4) release controlled by diffusion from beneath an infiltration barrier. To use TRANSS, the user supplies only certain minimal parameters: 1) a probabilityweighted list of travel times for streamlines, 2) a local-scale dispersion coefficient, 3) a sorption distribution coefficient, 4) total initial radionuclide inventory, 5) radionuclide half-life, 6) a release model choice, and 7) size dimensions of the source.

Key Words: EFFLUENTS AND WASTE - groundwater transport, radionuclides, TRANSS model

\section{S-17}

Singarella, P. N., and D. N. Brocard. 1982. $\underline{\mathrm{Hy}-}$ drothermal Modelling of Cooling Water Diffuser Qutfall, Hanford Generating Station. Prepared for Washington Public Power Supply System by Alden Research Laboratory, Worchester Polytechnic Institute, Holden, Massachusetts. 31 p., App. A and B.

Abstract: HGP discharges once-through cooling water to the Hanford Reach through a submerged line with four outlet ports. A hydrothermal model was used to predict the effect of proposed changes in outfall design, and how the changes would enhance dilution and satisfy thermal criteria of fisheries agencies. A 1/50 hydraulic model was first verified. The model's output closely scaled the field data, confirming its ability to predict proposed changes. Three outfall designs, all replacing the existing single-port outlets with multi-nozzle outlets, were then tested. Modification $3 \mathrm{~B}$ satisfied thermal criteria with a safety margin of $1.9^{\circ} \mathrm{C}\left(3.4^{\circ} \mathrm{F}\right)$ at a low river flow (36,000 cfs), and produced fairly uniform temperature rises downstream. 
Key Words: HANFORD SITE - cooling water discharge, HGP operation, outfall diffuser design, thermal plume mixing

\section{S-18}

Sisson, J. B., and A. H. Lu. 1984. Field Calibration of Computer Models for Application to Buried Liquid Discharges: A Status Report. RHO-ST-46 P, Rockwell Hanford Operations, Richland, Washington.

Abstract: A field experiment was conducted to calibrate computer models. Data were obtained from observation wells around a shallow injection well in the 200 East Area by injecting water and tracers $\left({ }^{85} \mathrm{Sr}\right.$ and ${ }^{134} \mathrm{Cs}$ at a $5.7-\mathrm{cm}$ depth. The general shape of the water plume and the injection pulse effect on water content could be simulated when layered soil properties were included in the model. Initial soil moisture contents in subsurface sediments ranged from 4 to 8 vol\%. After 11,000 gal was injected, water contents ranged from 4 to $26 \mathrm{vol} \%$, and lateral spreading occurred over a radius of $9 \mathrm{~m}$. Field data were compared directly to the output from the model. Model inputs were estimated from in situ information, and forecasts of moisture movement were made. Forecasts were biased at some points in the system. The bias could be removed by improving estimates of the parameters. The model correctly forecast that horizontal movement would dominate in situ wetting patterns.

Key Words: GEOLOGY AND HYDROLOGY computer modeling, ground-water movement, hydraulic conductivity, soil moisture, 200 Areas

\section{S-19}

Skaggs, R. L., and W. H. Walters. 1981. Flood Risk Analysis of Cold Creek Near the Hanford Site. RHO-BWI-C-120 / PNL-4219, Pacific Northwest Laboratory, Richland, Washington. $47 \mathrm{p}$.

Abstract: Flood potential at a possible $18-\mathrm{m}^{2}$ reference repository location (RRL) on the Hanford Site was analyzed as part of BWIP. Objectives were to 1) identify possible effects of flooding, and 2) provide a preliminary basis for protecting surface facilities and access roads against flooding. A review of historical and theoretical flooding of the Columbia and Yakima rivers indicated no direct danger to the RRL. However, the probable maximum flood would inundate about $3.5 \mathrm{mi} 2$ of the site, and the maximum possible depth at the widest part of the flood plain would be about $7.7 \mathrm{ft}$. Under such extreme conditions, access to the RRL from the east and north would likely be unimpaired, although Route 240 would be flooded. This assessment is conservative.

Key Words: HANFORD SITE - BWIP site, Cold Creek Valley, environmental assessment, flood potential

\section{S-20}

Sliger, G. J. 1982. Radioactive Liquid Waste Discharged to Ground in the 200 Areas During 1981. RHO-HS-SR-81-3 4QLIQ, Rockwell Hanford Operations, Richland, Washington. 234 p., App. 1.

Abstract: In 1981, the 200 Areas had 23 liquid effluent discharges, 20 of which were normally or potentially contaminated with radioactive material. Of these 20 effluents, three discharged radioactivity above DOE concentration guides. B Plant process condensate exceeded ${ }^{137} \mathrm{Cs}$ values by $150 \%$, discharging to the 216-B-62 crib. PUREX process condensate exceeded ${ }^{\circ} \mathrm{Sr}$ limits by $50 \%$, discharging to the 216-A-10 crib. $\mathrm{UO}_{3}$ Plant condensate (at U-12) exceeded total uranium limits by $7 \%$, discharging to the $216-\mathrm{U}-12$ crib.

Key Words: EFFLUENTS AND WASTES - environmental monitoring, radioactive liquids, radioactivity, waste disposal/treatment, 200 Areas

\section{$S-21$}

Sliger, G. J. 1983. Radioactive Liquid Waste Discharged to Ground in the 200 Areas during 1982. RHO-HS-SR-82 4QLIQ P, Rockwell Hanford Operations, Richland, Washington. 224 p., app. 1.

Abstract: In 1982, the 200 Areas had 25 liquid effluent discharges, 21 of which were normally or potentially contaminated with radioactive material. Of these 21 effluents, three discharged radioactivity above DOE concentration guides. B Plant process condensate exceeded $90 \mathrm{Sr}$ values by a factor of 15 and ${ }^{137} \mathrm{Cs}$ values by a factor of 3.5 ; both discharged to the 216-B-62 crib. PUREX process condensate 
exceeded ${ }^{137} \mathrm{Cs}$ values by a factor of 2.6 , discharging to the $216-\mathrm{A}-10 \mathrm{crib}$. UO $\mathrm{U}_{3}$ Plant condensate (at U12) exceeded total uranium limits by a factor of 11 . Note: uranium limits were recently reduced and changes were made at the $\mathrm{UO}_{3}$ Plant to meet the new limits.

Key Words: EFFLUENTS AND WASTES - environmental monitoring, radioactive liquids, radioactivity, waste disposal/treatment, 200 Areas

\section{$S-22$}

Smith, M. J., et al. (15 coauthors). 1980. Engineered Barrier Development for a Nuclear Waste Repository in Basalt: An Integration of Current Knowledge. RHO-BWI-ST-7, Rockwell Hanford Operations, Richland, Washington. Irregular pages.

Abstract: The United States has adopted a multiple barrier approach to long-term storage and disposal of high-level radioactive wastes since 1977 . This approach involves the concept of engineered barriers acting with natural barriers to prevent unacceptable release of radionuclides. The effort (BWIP) aims to specify, for each candidate waste form, an effective, site-specific barrier system for a repository in basalt (at Hanford). This report uses a five-component system comprised of waste form, canister, buffer, overpack, and backfill but is not necessarily a final design.

After an introduction, major sections of the report concern multiple barriers and borehole plugging. Section titles under multiple barriers are: 1) Functions of the Engineered Barriers System, 2) Rock Characteristics and Geological Setting, 3) Groundwater Composition, 4) Repository Conditions, 5) Waste Forms, 6) The Canister and Overpack, 7) Backfills and Other Engineered Barriers, 8) WasteBasalt Interactions, 9) Sorption Studies, and 10) Preliminary Modeling of the Near-Field Environment. Section titles under borehole plugging are: 1) Concepts, 2) Description of the Environment, 3) Selection of Candidate Plug Materials, 4) Emplacement Machines, 5) Laboratory Testing, 6) Preconceptual Plug Design, and 7) Borehole Plugging Field Tests.
Key Words: EFFLUENTS AND WASTES geologic disposal, Hanford Site, multiple barriers, radioactive waste, remedial assessment, waste disposal

\section{S-23}

Smith, M. R., J. C. Laul, and V. G. Johnson. 1987. "Natural Radionuclides in Hanford Site Ground Waters." Mater, Res. Soc. Symp. Proc. 112:249-257.

Abstract: Natural concentrations of uranium, thorium, radium, radon, and polonium radionuclides were examined in ground waters beneath the Hanford Site. Uranium, thorium, and radium were highly sorbed. Relative to radon, these radionuclides were low by factors of $10^{-3}$ to $10^{-6}$. Uranium sorption was likely caused by its reduction from the +6 state, where it was introduced via surface waters, to the +4 state in the confined aquifers. The distribution of radionuclides was very similar in all confined aquifers and significantly different from the distribution in the unconfined aquifer and surface waters. Barium correlated well with radium over three orders of magnitude, indicating that stable element analogs might be useful for inferring the behavior of radioactive waste radionuclides beneath Hanford, a candidate geologic repository.

Key Words: RADIOACTIVITY - background radiation, ground-water characteristics, Hanford Site, radionuclides

\section{S-24}

Smith, R. M. 1980. 216-B-5 Reverse Well Characterization Study. RHO-ST-37, Rockwell Hanford Operations, Richland, Washington. $120 \mathrm{p}$.

Abstract: Some waste generated by processing of irradiated nuclear fuels at Hanford has been released to the ground by means of "reverse wells." The 216B-5 reverse well was one of the first. It was used from 1945 to 1947 to receive alkaline, low-salt, radioactive liquids from a plutonium recovery plant (B Plant). The system consisted of a settling tank, where the solids settled, and a reverse well, for the overflow liquids. Overall, about $3.1 \times 10^{7} \mathrm{~L}$ of liquids containing about $4.3 \mathrm{~kg}$ of plutonium were released to the well. 
The area near the 216-B-5 reverse well was investigated during 1979 and 1980 by drilling wells and collecting sediment samples for analysis to determine the distribution of radionuclides sorbed on the sediments. Two wells drilled about $1 \mathrm{~m}$ from the settling tank showed no contamination, indicating it had not leaked. Sediment samples from four wells extending down to basalt were analyzed for ${ }^{239 / 240} \mathrm{Pu},{ }^{137} \mathrm{Cs}$, and ${ }^{90} \mathrm{Sr}$ near the reverse well. Levels of plutonium and strontium exceeding $10 \mathrm{nCi} / \mathrm{g}$ were limited to within $6 \mathrm{~m}$ of the well. Levels of plutonium exceeding 100 $\mathrm{nCi} / \mathrm{g}$ were limited to a narrow (1-m) layer of sediment representing the 1948 water table. Cesium had moved laterally away from the well in a layer of silt in the unsaturated sediments (position of the 1948 water table) and at the basalt surface. Ground water beneath the well contained radionuclides at orders of magnitude less than drinking water standards.

Key Words: EFFLUENTS AND WASTES - cesium, plutonium, radioactive liquids, soil percolation (in situ), soil sorption (in situ), strontium, 200 Areas, 216-B-5 reverse well

\section{S-25}

Sneider, S. C., and R. L. Skaggs. 1983. Unsteady Flow Model of Priest Rapids Dam Releases at Hanford Reach. Columbia River, Washington. PNL4527, Pacific Northwest Laboratory, Richland, Washington. 36 p., App. A and B.

Abstract: A model was developed to simulate water level changes from discharges past Priest Rapids Dam at three locations in the Hanford Reach. The model was calibrated and verified over a range of flows. Results indicated that the model, with reasonable accuracy, simulated river stages to within $+/-0.08 \mathrm{~m}(0.25 \mathrm{ft})$ and surface wave timing to within $+/-20 \mathrm{~min}$. The model can be used to evaluate and quantify possible impacts on aquatic organisms, water supply, navigation, irrigation, recreation, and additional power enhancement. Although the results are site-specific, the method is generic and can be adapted to other river systems.

Key Words: HANFORD SITE - ecological modeling, Hanford Reach, water-level fluctuations
$S-26$

Soldat, J. K., K. R. Price, and W. D. McCormack. 1986. Offsite Radiation Doses Summarized from Hanford Environmental Monitoring Reports for the Years 1957-1984. PNL-5795, Pacific Northwest Laboratory, Richland, Washington.

Abstract: Evaluation of offsite impacts from radioactivity generated at Hanford has been summarized in publicly available environmental reports each year since 1957. The evaluations include estimates of potential radiation exposure to the public, either in terms of radiation dose or percentages of the thenpermissible limits.

This document discusses data from the annual reports. Estimated potential radiation dose to a maximally exposed individual (MEI) from each year of Hanford operations are in tables and figures, and the applicable standard for radiation dose for each year is shown. According to their availability, methods and data used in developing the annual dose estimates are summarized in an annotated bibliography. The sum of the annual estimates will not give an accurate estimate of doses accumulated over this period. The estimates were the best evaluations possible at that time. Evaluations of public exposure have constantly improved. As a result, the methods and assumptions used to estimate doses were periodically modified to add new pathways and increase prediction accuracy.

Three conclusions were reached: 1) radiation doses reported from 1957 through 1984 for the MEI did not exceed applicable dose standards; 2) while the doses reported over 27 years were not additive, the total whole-body dose received by a hypothetically MEI from Hanford operations would be less than 1000 mrem (this value compares to over $3000 \mathrm{mrem}$ received by local residents over the same period from natural background and worldwide fallout); and 3) results from environmental monitoring over 27 years did not suggest a significant dose contribution from the buildup of radioactivity in the environment by Hanford operations.

Key Words: RADIOACTIVITY - radiation dose estimates, exposure assessment, Hanford Site emissions, historical review 
Abstract: The quality of drinking water on the

Sommer, D. J., R. G. Rau, and D. C. Robinson. 1981. Population Estimates for the Area Within a 50-Mile Radius of Four Reference Points on the Hanford Site. PNL-4010, Pacific Northwest Laboratory, Richland, Washington. $19 \mathrm{p}$.

Contents: Bureau of Census data released in 1980 were used to identify population distribution a 50 mile radius around the Hanford Site. A 10-year population forecast was presented. Results are documented in Tables 12-13 and 15-18. Recent immigration made this update of previous distribution reports necessary.

Key Words: SOCIOECONOMICS - Benton/ Franklin counties, population distribution, population forecast, $80-\mathrm{km}$ radius

\section{S-28}

Somers, S. R. 1986. Hanford Sanitary Water Quality Surveillance CY-1985. HEHF-55, Hanford Environmental Health Foundation, Richland, Washington. $16 \mathrm{p}$.

Abstract: The quality of drinking water on the Hanford Site is examined each year by the HEHF to protect human health. In 1985, potable water was supplied by 18 systems, each consisting of a raw water supply, treatment facilities, and distribution piping. Thirteen systems used Columbia River water, four used ground water, and one (Richland municipal) used both. Data demonstrated continued compliance with drinking water standards for inorganic, organic chemical, microbiological, and radiological materials. Aesthetic limits were exceeded by four samples for iron and one for color (all related to piping corrosion).

Key Words: HANFORD SITE - environmental monitoring, drinking water, ground water, river water, water quality

\section{S-29}

Somers, S. R. 1987. Hanford Sanitary Water Quality Surveillance CY-1986. HEHF-59, Hanford Environmental Health Foundation, Richland, Washington. $17 \mathrm{p}$.
Hanford Site is examined each year by the HEHF to protect human health. In 1986, potable water was supplied by 19 systems, each consisting of a raw water supply, treatment facilities, and distribution piping. Fourteen systems used Columbia River water, four used ground water, and one (Richland municipal) used both. Data indicated general compliance with drinking water standards for inorganic, organic chemical, microbiological, and radiological materials. Aesthetic limits were exceeded in three samples for iron, two samples for manganese, and one sample for color (all related to piping corrosion).

Key Words: HANFORD SITE - environmental monitoring, drinking water, ground water, river water, water quality

\section{S-30}

Somers, S. R. 1988. Hanford Sanitary Water Quality Surveillance CY-1987. HEHF-71, Hanford Environmental Health Foundation, Richland, Washington. $20 \mathrm{p}$.

Abstract: The quality of drinking water on the Hanford Site is examined each year by the HEHF to protect human health. In 1987, potable water was supplied by 19 systems, each consisting of a raw water supply, treatment facilities, and distribution piping. Fourteen systems used Columbia River water, four used ground water, and one (Richland municipal) used both. Use of smaller systems declined. Data indicated general compliance with drinking water standards for inorganic, organic chemical, microbiological, and radiological materials. Aesthetic limits were exceeded for iron in one sample (from piping corrosion).

Key Words: HANFORD SITE - environmental monitoring, drinking water, ground water, river water, water quality

\section{$S-31$}

Spane, F. A., Jr., D. L. Graham, and R. W. Bryce. 1982. "Hydrochemical and Isotopic Content of Basalt Groundwaters Beneath the Hanford Site, Washington." RHO-BW-SA-190, Rockwell Hanford Operations, Richland, Washington. 27 p. 
Contents: Characterization of the hydrochemical and isotopic composition of ground water beneath the Hanford Site was an initial part of BWIP. Values analyzed over three years included major inorganics, trace elements, dissolved gas, and stable and unstable isotopes. Data are presented and the findings were briefly discussed.

Key Words: GEOLOGY AND HYDROLOGY chemical analyses, confined aquifer, ground water, Hanford Site, hydrochemical data, water quality

\section{S-32}

Springer, J. T. 1982. "Movement Patterns of Coyotes in South Central Washington." L. Wildl. Manage. 46:191-200.

Abstract: Ten coyotes were fitted with radio transmitters on the Hanford Site and located daily over 1 to 15 months. Because most of the locations (83\%) were in a small part (7\%) of an animal's total home range, each home range was subdivided into an "impact area" and 1 or more "core areas." The "impact area" was the area through which a coyote traveled and interacted with other animals. "Core areas" were relatively small areas receiving heavy use by coyotes. No relationships were found between daily movements and relative or absolute changes in mean daily temperature and mean daily barometric pressure, or moon changes. Parameters for daily movement, core area size, and home range size, respectively, changed by season: Fall $-3.1 \mathrm{~km}, 5.3$ $\mathrm{km}^{2}, 28.6 \mathrm{~km}^{2}$; Winter $-4.7 \mathrm{~km}, 13.2 \mathrm{~km}^{2}, 143 \mathrm{~km}^{2}$; Spring - $2.6 \mathrm{~km}, 8.3 \mathrm{~km}^{2}, 58.2 \mathrm{~km}^{2}$; Summer $-3.3 \mathrm{~km}$, $3.2 \mathrm{~km}^{2}, 54.5 \mathrm{~km}^{2}$; and overall $-3.4 \mathrm{~km}, 7.8 \mathrm{~km}^{2}, 92.4$ $\mathrm{km}^{2}$. Disturbance levels were low.

Key Words: TERRESTRIAL ECOLOGY - behavior, coyote, daily movement, Hanford Site, home range

\section{S-33}

Squires, D. J. 1985. "Basalt Waste Isolation Project Institutional Interactions." In Waste Management '85, Proceedings of the Symposium on Waste Management, Vol, 3 Waste Policies and Programs. General Interest. ed. R. G. Post, pp. 99-102. University of Arizona Press, Tucson, Arizona.
Abstract: Activities associated with institutional interactions arising from the BWIP are discussed. Interactions take the form of reviews of documents and reports by the public, state, and federal agencies, affected Indian tribes, and many others. Interactions also include meetings, briefings, hearings, and tours of BWIP facilities by these groups. BWIP desires to conduct an open forum and make all data available. The interactive process is a major step in implementing the Nuclear Waste Policy Act.

Key Words: SOCIOECONOMICS - BWIP, project interactions, public information

\section{S-34}

Steigers, W. D., Jr., and J. T. Flinders. 1980. “Mortality and Movements of Mule Deer Fawns in Washington." I. Wild1, Manage, 44:381-388.

Abstract: In 1977, 39 mule deer fawns on the Hanford Site were captured and fixed with radio transmitters to examine factors responsible for neonatal mortality. Fawns were located daily May through August and monthly September through December. During the first 3 months of life, each fawn traveled an average of $438 \mathrm{~m}$, but this distance was highly variable. The home range for fawns about 60 days old or older averaged 257 ha. Fourteen of 26 instrumented fawns died. Coyotes accounted for 10 losses, drowning 3, and circulatory collapse 1 . Age was not reliable as the sole factor for predicting fawn movement. Intensive removal of coyotes on the Hanford Site would probably not substantially reduce fawn mortality.

Key Words: TERRESTRIAL ECOLOGY - coyote, ecological relations, mortality/survival, mule deer, predation

\section{S-35}

Stenner, R. D., K. H. Cramer, K. A. Higley, S. J. Jette, D. A. Lamar, T. J. McLaughlin, D. R. Sherwood, and N. C. Van Houten. 1988. Hazard Ranking System Evaluation of CERCLA Inactive Waste Sites at Hanford, Vol. 1 Evaluation Methods 
and Results. PNL-6456 Vol. 1, Pacific Northwest Laboratory, Richland, Washington. Irregular pages, App. A and B.

Contents: This report presents Hazard Ranking System (HRS) evaluations for waste disposal sites at Hanford, and was done as part of preliminary assessment/site inspection activities for the DOE. Four main efforts were completed. First, 335 engineered-facility sites were scored by the HRS. Second, 20 newly designated, engineered-facility sites were identified, investigated, and scored. Third, 291 unplanned-release sites were identified, investigated, and scored. Fourth, inactive waste sites at Hanford were separated into four aggregate sites for administration, and a HRS was developed for each. The aggregate sites and their HSR Mitigation Scores (in parentheses) were: 100 Areas (46.24), 200 Areas (69.05), 300 Area (65.23), and 1100 Area (36.33). The 646 waste sites identified in this report represent those CERCLA (pre-1980) sites at Hanford for which an existence/status had been documented. Potential new sites may be discovered as remedial work progresses.

Key Words: EFFLUENTS AND WASTE - remedial assessment, hazard ranking system, radioactive waste management, waste characterization, waste disposal sites

\section{S-36}

Stickney, R. G. 1988. Hanford Radioactive Solid Waste Packaging, Storage, and Disposal Requirements. WHC-EP-0063, Rockwell Hanford Operations, Richland, Washington. 63 p., App. A through J.

Contents: WHC (in 1988) manages and operates facilities at the Hanford Site that include radioactive solid waste disposal areas and radioactive solid waste storage areas. This manual defines the requirements that must be met by those who generate radioactive solid waste for the material to be accepted by WHC for storage or disposal at 200 Area facilities. The manual must also be used by all generators preparing radioactive solid waste for storage or disposal at Hanford Site facilities. Requirements in the manual represent a compilation of state and federal regulations, DOE Orders, Hanford Site requirements, and other rules, regulations, guidelines, and standards as they apply. This manual provides guidance to generators in meeting applicable requirements for 1) general needs, 2) transuranic wastes, 3) low-level wastes, and 4) mixed wastes.

Key Words: EFFLUENTS AND WASTES Hanford Site, packaging/storage requirements, radioactive solid waste, radioactive waste management, waste disposal

\section{S-37}

Stokowski, P. A., and E. A. Friedli. 1987. Interim Profile Report Socioeconomic Conditions in Cultural Communities: The Nez Perce Tribe. The Confederated Tribes of the Umatilla Indian Reservation and the Confederated Tribes and Bands of the Yakima Indian Nation. Working Draft, BWIP Repository Project. PNL-6386 (BHARC-800/87/021), Pacific Northwest Laboratory, Richland, Washington. $35 \mathrm{p}$.

Contents: This is one of five Socioeconomic Profile Reports produced by BWIP before the effort ended in late 1987. The reports provided community information associated with Hanford, then a possible site for the nation's first geologic repository. This report profiles the social and economic characteristics of Indian communities of the Nez Perce, Umatilla, and Yakima reservations. It has five sections: Background and Overview, Methods, Profile of Socioeconomic Conditions in Cultural Communities, Outstanding Technical Issues and Data Requirements, and References. Conditions discussed are Land Area and Ownership, Tribal Affiliation and Enrollment Status, Residential Mobility, Demographic Characteristics, Educational Characteristics, Economic Characteristics, and Housing Characteristics. Additional information is needed in several areas.

Key Words: SOCIOECONOMICS - BWIP, affected Indian tribes, social and economic status, $\mathrm{Nez}$ Perce Tribe, Umatilla Tribes, Yakima Tribes and Bands

\section{S-38}

Stone, W. A., J. M. Thorp, O. P. Gifford, and D. J. Hoitink. 1983. Climatological Summary for the Hanford Area. PNL-4622, Pacific Northwest Laboratory, Richland, Washington. Irregular pages, App. I through V. 
Abstract: Data from the HMS from 1946 to 1980 are summarized, along with precipitation and temperature data taken by others from 1912 to 1943. Precipitation on the Hanford Site is affected by the Cascade Mts. west of Yakima, and averages only 6.25 in. annually. November through January contributes $44 \%$ of this total, June through September only $12 \%$. About $38 \%$ of all precipitation from December through February is snow, but 6 in. of snow cover can be expected only one year in four. The greatest depth of snow recorded on the ground was $24.5 \mathrm{in}$., which occurred in February 1916; after that, the greatest depth was 12.1 in. in December 1964.

The Cascades provide cold air drainage, and greatly affect winds at Hanford. Gravity plus topographic channeling pulls the cold air and causes diurnal wind speed to vary during summer. In July, hourly average 50 -ft speeds range from a low of 5.2 $\mathrm{mph}(9$ to $10 \mathrm{am})$ to a high of $13.0 \mathrm{mph}(9$ to $10 \mathrm{pm})$. Corresponding speeds for January are 5.5 and 6.3 $\mathrm{mph}$. Although gravity winds occur regularly during summer, they are seldom strong unless reinforced by frontal activity. Channeling results in a prevailing WNW or NW wind the year-round, but the strongest winds are from the SSW, SW, and WSW. Atmospheric stagnation is important at Hanford. December averages 10 days with peak wind gusts under 13 $\mathrm{mph}$, while June has one such day every 5 years.

Hanford is shielded from many Arctic surges, and one haif of all winters are free of temperatures below $0^{\circ} \mathrm{F}$. However, 6 winters in 63 recorded had temperatures of $-20.0^{\circ} \mathrm{F}$ or below. Maximum temperatures did not rise above zero on 10 days of record. Winter minima range from $-27.0^{\circ}$ to $+22^{\circ} \mathrm{F}$, and summer maxima from $100^{\circ}$ to $115^{\circ} \mathrm{F}$, but frequency of such maxima vary. Although temperatures reach $90^{\circ} \mathrm{F}$ or above about 55 days each year, minimum temperatures $70^{\circ} \mathrm{F}$ or above average only 8 days. Cool nights result from gravity winds. Thunderstorms have occurred every month except November and January. Severe storms are rare, but lightning may ignite grass fires on the Hanford Site. One tornado and two funnel clouds were seen in 36 years.

Key Words: AIR AND ATMOSPHERE - Hanford Site, historical review, weather conditions
S-39

Strait, S. R., and B. A. Moore. 1982. Geohydrology of the Rattlesnake Ridge Interbed in the Gable Mountain Pond Area. RHO-ST-38, Rockwell Hanford Operations, Richland, Washington. 73 p., App. A through C.

Abstract: Liquid waste disposal at Hanford includes the release of low-level radioactive waste to cribs, trenches and ponds. A conceptual ground-water flow model was developed to characterize the current distribution of radionuclides in the Rattlesnake Ridge interbed at one of these facilities, the Gable Mountain Pond. Special wells were drilled near the pond. The highest radionuclide levels detected were in the uppermost confined aquifer in the southern part of the study area. However, the levels were several orders of magnitude below concentration guides for water in an uncontrolled area in Chapter XI of DOE Order 5480.1. Radionuclides entered the confined aquifer at an eroded area in the uppermost basalt flow. Elevated ground waters provided the force to move contaminated water from the unconfined to confined aquifer. In the study area, the hydraulic conductivity of the Rattlesnake Ridge interbed is 0.75 to $25.1 \mathrm{ft} / \mathrm{day}$, and ground water flows to the southwest.

Key Words: GEOLOGY AND HYDROLOGY Gable Mt. Pond, ground-water movement, hydraulic conductivity, Rattlesnake Ridge interbed, unconfined aquifer

$S-40$

Strait, S. R., and F. A. Spane, Jr. 1984. Hydrologic Test Results for the Upper Cohassett Flow Interior at Borehole RRL-2, Hanford Site, Washington State. RHO-BW-ST-51 P, Rockwell Hanford Operations, Richland, Washington. 20 p., App. A and B.

Abstract: The results of hydrologic tests in the upper Cohassett flow interior at borehole RRL-2 over the depth of 3,057 to $3,172 \mathrm{ft}$ were described. Hydrologic tests included an over-pressure pulse test and a constant head injection test. Preliminary results indicated that transmissivity values ranged from $1.8 \mathrm{x}$ $10^{-6}$ to $1.7 \times 10^{-4} \mathrm{ft}^{2} / \mathrm{day}$, with an assigned best estimate of $1.7 \times 10^{-4} \mathrm{ft}^{2} /$ day. The best estimate of 
hydraulic conductivity, based on a thickness for the effective test interval of $115 \mathrm{ft}$, was $1.5 \times 10^{-6} \mathrm{ft} /$ day. These best-estimate values were consistent with results previously reported for similar Grande Ronde basalt horizons.

\section{Key Words: GEOLOGY AND HYDROLOGY -} borehole data, Grande Ronde basalt, hydraulic conductivity, transmissivity

\section{$S-41$}

Strickler, J. J., H. A. Wallskog, and J. R. Welch. 1980. The System for Retrieval of Solidified Hanford High-Level Defense Wastes: A Design Description. RHO-ST-33, Rockwell Hanford Operations, Richland, Washington. Irregular pages, App. A.

Abstract: Plans are under way to retrieve defense waste now stored in underground concrete tanks at Hanford. This report gives the preliminary design of a remotely controlled, self-contained, mobile system that has a mechanical, articulated mining boom. This boom, when equipped with suitable tools, can remotely cut up in-tank equipment, remove the debris, recover some solid wastes, clean the tank walls, and deposit the waste in a bucket elevator. The elevator automatically removes the waste from the tank and deposits it in shielded shipping containers. The containers are remotely sealed, washed, and deposited into sealing containers for transport to a waste processing facility or repository. All retrieval equipment is installed on a mobile platform that bridges the tank domes. Ancillary equipment includes in-tank viewing and lighting systems, positive filtered ventilation equipment, tool-washing and mining equipment, and mechanisms for moving from tank to tank.

Key Words: EFFLUENTS AND WASTES - highlevel wastes, Hanford Site, radioactive waste management, retrieval and processing, remedial plans, waste storage tanks, 200 Areas

\section{$S-42$}

Sula, M. J. 1980. Radiological Survey of Exposed Shorelines and Islands of the Columbia River between Vernita and the Snake River Confluence.
PNL-3127, Pacific Northwest Laboratory, Richland, Washington. 42 p, App. A through E.

Abstract: Exposed shorelines and islands were surveyed in the Hanford Reach from the $100 \mathrm{~B}$ Area downstream to above the Snake River outlet to determine radioactive contamination. External exposure rates were measured at nearly 30,000 locations, accounting for about $60 \%$ of the shoreline area. Radioactivity from past Hanford operations was present. Absence of short-lived radionuclides and the presence of contamination several meters above recent maximum river levels indicated that deposition occurred years ago.

Contamination was of three types: 1) a fairly constant, uniformly distributed layer over the entire study area that averaged $11 \mu \mathrm{R} / \mathrm{hr}$, compared to a background of $7 \mu \mathrm{R} / \mathrm{hr}$ upstream of Hanford; 2) 92 areas where readings exceeded $25 \mu \mathrm{R} / \mathrm{hr}$, presumable "contamination deposits" where sediments containing radionuclides had been left by river action. The highest readings were at White Bluffs Slough (to 40 $\mu \mathrm{R} / \mathrm{hr}$ ), Hanford Townside Peninsula (to $45 \mu \mathrm{R} / \mathrm{hr}$ ), and Island-344 near the 300 Area ( $38 \mu \mathrm{R} / \mathrm{hr}$ ). Samples of soil and vegetation from several deposition sites revealed a mixture of ${ }^{60} \mathrm{Co},{ }^{137} \mathrm{Cs}$, and ${ }^{152} \mathrm{Eu}$ in about equal proportions; 3) discrete, contaminated particles - metallic flakes, possibly fragments of stelite valves and pump components in the closeddown, production reactors, that contained from 1.7 to $24 \mu \mathrm{Ci}$ of ${ }^{60} \mathrm{Co}$. External dose rates from the first two types were below applicable external radiation dose limits for uncontrolled areas. The usual doseresponse relations were not valid for discrete particles.

Key Words: RADIOACTIVITY - assessment, environmental monitoring, cesium-137, cobalt- 60 , europium-152, Hanford Reach shorelines

\section{$S-43$}

Sula, M. J. and D. E. Bihl. 1986. Bioassay Measurements of Individuals Living Near the U.S. Department of Energy's Hanford Site in Washington State Fall 1985. PNL-5843, Pacific Northwest Laboratory, Richland, Washington. 13 p., App. A through F.

Abstract: In fall 1985, special bioassays were conducted to provide individuals living in northwest 
Franklin County with information on current levels of radionuclides in their bodies. The methods involved whole body counts, which measure the radiation emitted by radioactive materials in the body, and urinalyses, which measure radioactivity in excreted materials. A notice was sent to 515 households. Eventually, 89 individuals from 52 households requested and received whole body counts, and 32 of these individuals also provided urine samples.

Radioactivity, other than naturally occurring ${ }^{40} \mathrm{~K}$, was not detected in any individual. When individual analyses were pooled, statistical treatment indicated that the test group contained normal levels of tritium, as expected because of its worldwide presence in the environment. Statistics provided no evidence of any other types of radioactivity that might be associated with the Hanford Site. Analysis of bioassay capabilities showed that, within certain time constraints, the measurements would detect an intemal radiation exposure of about the same magnitude as that normally received from natural radiation.

Key Words: RADIATION - assessment, Hanford Site releases, public monitoring, whole body counts, urinalysis

\section{S-44}

Sula, M. J. and P. J. Blumer. 1981. Environmental Surveillance at Hanford For CY-1980. PNL-3728, Pacific Northwest Laboratory, Richland, Washington. 45 p., App. A through E.

Abstract: Data collected in 1980 by PNL's Environmental Monitoring Program are reviewed. Samples taken on and off the Hanford Site provide data to assess amounts of radioactivity and chemicals from operational and natural sources. Results are given in sections entitled: Atmospheric Monitoring, Columbia River Monitoring, Foodstuffs, Wildlife, Soil and Vegetation, and External Radiation. In addition, the Radiological Impact of Hanford Operations is assessed. Support data are in Appendices.

Offsite levels of radionuclides attributable to 1980 Hanford operations were indistinguishable from background levels. Levels of ${ }^{129} I$ in Columbia River water apparently increased, but still remained negligible in comparison to drinking water guides and standards. Low levels of radionuclides from past
Hanford operations occurred in some samples of whitefish, ducks, and mule deer ( ${ }^{139} \mathrm{I}$ in thyroid). A few long-lived radionuclides (mainly ${ }^{60} \mathrm{Co}$ and ${ }^{154} \mathrm{Eu}$ ), at elevated but still low levels, were detected on Columbia River shorelines and islands.

The maximum annual whole-body dose to an individual from 1980 effluents was a calculated 0.01 mrem (compared to a 500-mrem regulatory standard). The maximum annual dose to a single organ was about $0.7 \mathrm{mrem}$ to the thyroid of a hypothetically exposed infant (compared to a 1,500-mrem regulatory standard). Effluents resulted in a 50-year wholebody dose commitment to the population within an $80-\mathrm{km}$ (50-mile) radius of about 0.6 man-rem (compared to about 25,000 man-rem from natural background radiation).

Thermal limitations under the National Pollutant Discharge Elimination System permit were exceeded several times by Hanford effluents, but had negligible effect on the Columbia River. Particulate emissions from two coal-fired power plants exceeded standards during 1980. Both excesses are being corrected. Standards for total suspended particulates in ambient air were frequently exceeded in the Columbia Basin, primarily by construction and agricultural activities.

Key Words: HANFORD SITE - air quality, effluents and emissions, environmental monitoring, food and farm products, ground water, Hanford Reach, penetrating radiation, radiation dose assessment, regulatory compliance, soil and vegetation, water quality

\section{S-45}

Sula, M. J., P. J. Blumer, and R. L. Dirkes. 1981. Environmental Status of the Hanford Site for CY. 1980. PNL-3729, Pacific Northwest Laboratory, Richland, Washington. 54 p., App. A and B.

Abstract: Data are presented from surface samples taken within Hanford's boundaries in 1980 by PNL's Environmental Monitoring Program. Radiological conditions near onsite operating areas, unusual occurrences at operating areas, and radioactive and nonradioactive discharges are reported and discussed.

Gross beta levels in airbome particulates increased towards the end of 1980 as a result of fallout from an atmospheric nuclear test by the People's Republic of 
China on October 16,1980 . No artificially produced gamma-emitting radionuclides were identified in airbome particulates other than low levels from atmospheric fallout. Airborne ${ }^{90} \mathrm{Sr}$, plutonium, and tritium measured onsite did not differ significantly from background levels, and radioiodine was not identified. Levels of ${ }^{90} \mathrm{Sr}$ and ${ }^{137} \mathrm{Cs}$ were somewhat higher in B Pond water compared to past years, but remained well below applicable concentration guides. Tissue samples from onsite wildlife indicated that radionuclides from past Hanford operations remained accessible in some areas. Several soil and vegetation samples had radionuclides above background levels but only at levels recently reported.

External doses during 1980 were above background levels at several locations because of onsite activities. Dose rates north of the 300 Area increased after a steam generator, removed from the Surry Nuclear Station, was placed near the dosimeter location. No instances of roadway contamination and one instance of railroad contamination (from shipping spent $\mathrm{N}$ reactor fuel to the $100 \mathrm{~K}$ Area) $\mathrm{oc}-$ curred. Discharges of radioactive and nonradioactive materials were generally lower than previous years because several facilities were shut down temporarily. There were 12 environmentally related unusual occurrences.

Key Words: RADIOACTIVITY - air and atmosphere, B Pond, environmental monitoring, Hanford Site emissions, onsite operations, penetrating dose, radionuclides, surface soil, vegetation, wildlife

\section{S-46}

Sula, M. J., P. J. Blumer, and R. L. Dirkes. 1982. Environmental Status of the Hanford Site for CY1981. PNL-4212, Pacific Northwest Laboratory, Richland, Washington. 52 p., App. A and B.

Abstract: Data are presented from surface samples taken within Hanford's boundaries in 1981 by PNL's Environmental Monitoring Program. Radiological conditions near onsite operating areas, unusual occurrences at operating areas, and radioactive and nonradioactive discharges are reported and discussed.

Airborne particulate radioactivity at Hanford was greater in early 1981 because of fallout from a foreign atmospheric nuclear test in late 1980 , but had returned to previous levels by year end. Airborne
${ }^{90} \mathrm{Sr}$, plutonium, and tritium at onsite stations were not significantly different from background levels, and radioiodine was not identified in 1981. Strontium- 90 and ${ }^{137} \mathrm{Cs}$ in B Pond water were lower than in 1980. Tissue samples from wildlife still indicated the presence of Hanford-produced radionuclides. Some onsite soil and vegetation samples contained radionuclides above background levels, as in past years. External penetrating dose measurements during 1981 were above background levels at several onsite locations; the most significant resulted from moving a radioactive steam generator in the 300 Area.

No contamination of roads or railroads was observed, and no significant changes occurred at the radioactive waste burial grounds. Discharges of radioactive and nonradioactive materials to the environment during 1981 were generally greater than in 1980 because of increased operational activities, particularly at FFTF and N Reactor. There were 11 environment-related unusual occurrences.

Key Words: RADIOACTIVITY - air and atmosphere, B Pond, environmental monitoring, Hanford Site emissions, onsite operations, penetrating dose, radionuclides, surface soil, vegetation, wildlife

\section{S-47}

Sula, M. J., P. J. Blumer, R. L. Dirkes, and J. M. J. Carlile. 1983. Environmental Status of the Hanford Site for CY-1982. PNL-4658, Pacific Northwest Laboratory, Richland, Washington. 56 p, App. A and $B$.

Abstract: Data are presented from surface samples taken within Hanford's boundaries in 1981 by PNL's Environmental Monitoring Program. Radiological conditions near onsite operating areas, unusual $\alpha$ currences at operating areas, and radioactive and nonradioactive discharges are reported and discussed.

Airborne particulate radioactivity at Hanford was generally lower in 1982 than in 1981 . Airborne ${ }^{90} \mathrm{Sr}$, ${ }^{137} \mathrm{Cs}$, and plutonium concentrations were not significantly different from background levels. Iodine-131 was not identified in any air sample, and tritium in atmospheric water vapor was similar at all sample locations. Cesium-137 levels in B Pond continued to decrease from a peak in 1980 , and ${ }^{90} \mathrm{Sr}$ levels were similar to those in 1981. Some Hanford-produced 
radionuclides were found in onsite wildlife. Several soil and vegetative samples contained radionuclides above background levels, but similar to those detected in the past.

External penetrating dose measurements in 1982 showed dose levels above background levels, similar to levels in 1981. No radioactive contamination was detected during routine surveys of roads and railroads. Reported discharges of radioactive and nonradioactive materials were similar to those in 1981. There were eight environmentally related unusual occurrences.

Key Words: RADIOACTIVITY - air and atmosphere, B Pond, environmental monitoring, Hanford Site emissions, onsite operations, penetrating dose, radionuclides, surface soil, vegetation, wildlife

\section{S -48}

Sula, M. J., J. M. V. Carlile, K. R. Price, and W. D. McCormack. 1983. Environmental Surveillance at Hanford for CY 1982. PNL-4657, Pacific Northwest Laboratory, Richland, Washington. 54 p., App. A through E.

Abstract: Data collected in 1981 by PNL's Environmental Monitoring Program are reviewed. Samples taken on and off the Hanford Site provide data to assess amounts of radioactivity and chemicals from operational and natural sources. Results are given in sections titled: Airborne Radioactivity, Columbia River Radiological Monitoring, Columbia River Water Quality Monitoring, Groundwater, Foodstuffs, Wildlife, Soil and Vegetation, and External Radiation. In addition, Radiological Impact and Potential Radiation Dose to the public are discussed. Support data are in Appendices.

There were no distinguishable differences in gross radioactivity or specific radionuclide levels in air samples at the edge of the Hanford Site compared with offsite control samples. Concentrations of ${ }^{129} \mathrm{I}$, ${ }^{131} \mathrm{I}$, and ${ }^{60} \mathrm{Co}$ in river water below Hanford, while somewhat higher than those above, remained well within applicable concentration guides. Low levels of ${ }^{60} \mathrm{Co},{ }^{131} \mathrm{I},{ }^{90} \mathrm{Sr}$, and tritium occurred in $\mathrm{N}$ Reactor effluents. Tritium occurred in seepage from the unconfined aquifer. Water quality in the Hanford Reach exceeded state standards only in isolated instances, which were apparently not associated with
Hanford activities. Foodstuffs contained low levels of radionuclides from atmospheric fallout. Radionuclides attributable to Hanford in wildlife were well below the applicable DOE radiation protection standard.

The radiation dose to the public from Hanford in 1982 was well below all applicable regulatory limits, and significantly less than potential doses from other common sources of radiation. The 50-year whole body cumulative dose equivalent that might be received by a hypothetical maximally exposed individual was $0.7 \mathrm{mrem}$ (compared to applicable standard of $500 \mathrm{mrem}$ ). Further, the 50-year whole body cumulative dose equivalent to the population within $80 \mathrm{~km}$ (50 miles) was a calculated 4 man-rem. These data can be compared to about $100 \mathrm{mrem}$ and 34,000 man-rem, respectively, received annually from naturally occurring and fallout radiation.

Key Words: HANFORD SITE - air quality, effluents and emissions, environmental monitoring, food and farm products, ground water, Hanford Reach, penetrating radiation, radiation dose assessment, radioactivity, regulatory compliance, soil and vegetation, water quality

\section{S-49}

Sula, M. J., W. D. McCormack, R. L. Dirkes, K. R. Price, and P. A. Eddy. 1982. Environmental Surveillance at Hanford for CY-1981. PNL-4211, Pacific Northwest Laboratory, Richland, Washington. 51 p., App. A through E.

Abstract: Data collected in 1981 by PNL's Environmental Monitoring Program are reviewed. Samples taken on and off the Hanford Site provide data to assess amounts of radioactivity and chemicals from operational and natural sources. Results are given in chapters entitled: Atmospheric Monitoring, Columbia River Monitoring - Radiological, Columbia River Monitoring - Nonradiological, Groundwater, Foodstuffs, Wildlife, and Soil and Vegetation. In addition, Penetrating Radiation and Radiological Impact of Hanford Operations are discussed. Support data are in Appendices.

Observed radionuclide concentrations and calculated dose measurements were far below applicable concentration guides and radiation dose standards in 1981. Strontium-90 levels in Columbia River water 
decreased above Hanford but remained the same downstream. Cobalt-60 and ${ }^{131}$ I were detected more frequently in downstream water samples than above, but were too low to be quantified. Several samples from wildlife taken near operating areas contained low-level radioactivity attributable to onsite operations. Soil and vegetation samples contained lowlevel radioactivity from worldwide fallout. The highest penetrating dose rates in the Hanford environs were near the $100 \mathrm{~N}$ and 300 areas, a result of radioactive materials contained in operating areas.

The maximum 50-year whole body dose commitment to an individual from effluents released in 1981 was a calculated $0.4 \mathrm{mrem}$ (compared to a $500 \mathrm{mrem} /$ yr dose standard). The maximum 50-year dose to a single organ was about $1.3 \mathrm{mrem}$ to bone (compared to a $1,500 \mathrm{mrem} /$ year dose standard). The 50 -year whole body dose commitment to the population within an $80-\mathrm{km}$ ( 50 mile) radius of Hanford was about 4 man-rem. This dose, primarily from shortlived noble gases released at $100 \mathrm{~N}$ Area, may be compared with the 34,000 man-rem whole body dose received each year from natural background radiation.

Key Words: HANFORD SITE - air quality, effluents and emissions, environmental monitoring, food and farm products, ground water, Hanford Reach, penetrating radiation, radiation dose assessment, radioactivity, regulatory compliance, soil and vegetation, water quality

\section{S-50}

Sula, M. J., and K. R. Price. 1983. PUREX Environmental Radiological Surveillance - Preoperational and Operational Support Program Conducted by Pacific Northwest Laboratory. PNL-4822, Pacific Northwest Laboratory, Richland, Washington. 67 p., App. A.

Contents: Radiological conditions were examined near the PUREX fuel processing plant before it resumed operations, planned for late 1983. In addition, preoperational radiological data collected to date (1982) and an environmental sampling program were summarized. The proposed PUREX radiological sampling program was discussed in the sections: Air Sampling, Foodstuffs, Wildlife Sampling, Soil Sampling, Vegetation Sampling, Environmental Dose
Rate Measurements, and Columbia River Sampling. Preoperational radionuclide concentrations were discussed in the sections: Airborne Radionuclide Concentrations, Foodstuffs, Wildlife, Soil and Vegetation, and Environmental Dose Rates. The activities described are part of the ongoing Hanford Environmental Sampling Program conducted by PNL.

Key Words: HANFORD SITE - environmental assessment, PUREX/UO ${ }_{3}$ startup, radioactivity

\section{S-51}

Summers, W. K., and G. Schwab. 1980. "Hydrology and Isotopic Analyses of Water in a Recharge Area, Eastern Washington". (Abstract) RHO-BWI-SA-71 A, Rockwell Hanford Operations, Richland, Washington.

Abstract: Field work from November 1978 to April 1979 disclosed 73 springs and 45 wells in part of the Rattlesnake Hills, Hanford Site. Water samples were analyzed from 23 springs, 6 wells, and 3 precipitation events. Analyses reported common solutes, tritium, deuterium, and ${ }^{18} \mathrm{O}$. No historical data existed for either stable-isotope or tritium in local precipitations. The ground water flow system apparently contained young water with low concentrations of solutes at higher altitudes. Ground water became older and gained higher concentrations of solutes as it moved through the rocks. Springs occurred where low permeability forced ground water to the surface.

\section{Key Words: GEOLOGY AND HYDROLOGY -} ground-water recharge, hydrochemical data, precipitation effects, Rattlesnake Mt., subsurface characteristics, surface recharge

\section{S-52}

Sutter, S. L. 1980. Potential Airborne Release from Soil-Working Operations in a Contaminated Area. PNL-3498, Pacific Northwest Laboratory, Richland, Washington. 21 p., App. A.

Abstract: Laboratory experiments indicated how much material would become airborne while soil was worked in a contaminated area. About $50 \mathrm{~kg}$ of contaminated soil were collected, dried, and mixed. 
Particle size and ${ }^{137} \mathrm{Cs}$ content were then characterized. This soil was pumped into an airstream moving at $3.2,10.4,15.2$, and $20 \mathrm{mph}$ in a wind tunnel ( 2 by $2 \mathrm{ft}$ ) at the Radioactive Aerosol Release Test Facility. The material deposited downstream was then sampled.

Deposited ${ }^{137} \mathrm{Cs}$ activity increased with wind speed at a rate about 4 times that of soil mass. These data can be used to estimate the fraction of material initially becoming airborne. Diffusion models can be used to estimate contamination levels downwind.

Key Words: RADIOACTIVITY - atmospheric dispersion, assessment, cesium-137, contaminated soil

\section{S-53}

Swan, G.A., E.M. Dawley, R.D. Ledgerwood, W.T. Norman, W.F. Cobb, and D.T. Hartman. 1988. Distribution and Relative Abundance of Deep-Water Redds for Spawning Fall Chinook Salmon at Selected Sites in the Hanford Reach of the Columbia River. National Marine Fisheries Service, Seattle, Washington. $59 \mathrm{p}$.

Abstract: A modified sled holding two divers was used to observe the spawning of fall chinook salmon and examine the river bed in eight sections of the Hanford Reach. The computerized data were translated into overlay maps that depicted substrate, depth contours, location of redds, and concentrations of spawning fish. Deep-water redds were detected at four of five sites where spawning took place. Water velocities above deep-water redds at the Midway and Vernita Sites were between 2.0 and $2.5 \mathrm{ft} / \mathrm{s}$. Depth of deep-water spawning averaged $21 \mathrm{ft}$, with a maximum of $30 \mathrm{ft}$. Physical features of the river channel, such as shoreline rocks and surface velocities, could be misleading indicators of spawning in deep water. A more extensive survey was needed to accurately estimate deep-water spawning throughout the Hanford Reach.

Key Words: AQUATIC ECOLOGY - anadromous fish, chinook salmon, Hanford Reach, spawning areas

\section{S-54}

Swanson, L. C., D. C. Weeks, S. P. Luttrell, R. M. Mitchell, D. S. Landeen, A. R. Johnson, and R. C.
Roos. 1988. Grout Treatment Facility Environmental Baseline and Site Characterization Report. WHC-EP-0150, Westinghouse Hanford Company, Richland, Washington. Irregular pages, App. A through D.

Abstract: The grout treatment facility (GTF) is planned as a shallow land burial site for low-level radioactive waste that is solidified by mixing the waste with a cementitious grout material. To determine if the GTF will affect the environment, baseline data must be defined for both preoperational environmental conditions and the current physical system. These data have been collected since 1984 . Completed descriptions of specific physical systems include: atmospheric, radioecologic, geologic, and hydrologic.

The GTF vaults will be situated belowground in excavated surface deposits and unsaturated, undifferentiated Hanford/Ringold formations. Atmospheric and thermoluminescent dosimeter (TLD) data indicated that airborne radionuclide levels were below maximum permissible concentrations from 1985 through 1987 . The TLD results ranged from 84 to $98 \mathrm{mrem} / \mathrm{yr}$ in 1987 . General, soil, and vegetation surveys at the site identified only low levels of radioactive contamination. Some areas had moderate levels of "spot" gamma contamination. Animals did not appear to be affected by waste management operations, nor did they transport radionuclides within the survey area. Strontium-90 values remained constant during the survey, but ${ }^{137} \mathrm{Cs}$ values showed some increases, probably from accidental release of materials from waste sites in 1984 and 1985.

The Hanford and Ringold formations were characterized at the GTF site, and data were used to complete a stratigraphic column and to construct cross-sections. Little or no contamination of radionuclides was detected in the sediment. The soil and upper $10 \mathrm{ft}$ of sediment had traces of cesium, strontium, and plutonium, probably from airborne particles released from facilities on the prevailing upwind side. Depth to ground water was about 265 $\mathrm{ft}$. Preliminary study of hydrogeology indicated that the saturated thickness of the unconfined aquifer ranged from $100 \mathrm{ft}$ in the north to $140 \mathrm{ft}$ in the south. The ground water flows generally from northeast to southwest at a hydraulic gradient of $0.0006 \mathrm{ft} / \mathrm{s}$. B Pond, northeast of the GTF site, influences the direction of ground-water flow and its recharge. 
Key Words: EFFL.UENTS AND WASTES - environmental assessment, grout treatment facility, radioactivity, remedial assessment, site characterization

T-1

Tallman, A. M., K. R. Fecht, M. C. Marratt, and G. V. Last. 1979. Geology of the Separations Areas. Hanford Site. South-Central Washington. RHO-ST23, Rockwell Hanford Operations, Richland, Washington. $134 \mathrm{p}$. (Relevant to 1980 's work.)

Abstract: The major geologic units beneath the Separation Areas were: first, basement rocks of undetermined origin; second, the Columbia River basalt group with intercalcated sediments of the Ellensburg Formation; third, the Ringold Formation; and fourth, the glaciofluvial sediments informally named the Hanford formation. A loess deposit, referred to as early "Palouse" soil, occurs beneath the Ringold and Hanford formations in parts of the 200 West Area. The area is veneered with loess and sand of varying thickness.

The Columbia River basalt group consists of a 5000 -ft thick sequence of basalt flows that, with associated Ellensburg sediments, are Miocene in age. The uppermost basalt flow has been dated at 10.5 million years old by the K/Ar method. The 200 Areas are situated on the gently dipping south flank of a basaltic ridge, the Umtanum-Gable Mountain structure.

The Ringold Formation, present throughout most of the 200 Areas, is a Pliocene fluvial sedimentary unit with some lacustrine sediments. It is divided into four main units - the silty sandy gravel of the basal Ringold unit (lying above the basalt), the silty sand to sandy silt of the lower Ringold unit, the silty sandy gravel of the middle Ringold unit, and the silty sand to sandy silt of the upper Ringold unit.

The Hanford formation lies on the eroded surface of the Ringold Formation, the early "Palouse" soil, and locally, the basalt baserock. Sediments of the Hanford Formation, deposited during Pleistocene catastrophic flooding, are the most significant geologic unit in the transport and sorption of radionuclides from surface and near-surface waste storage facilities. The Hanford sediments in the 200 Areas effectively isolate and sorb most radiocontaminants (half-life greater than one year) because of their thick sequence of unsaturated sediments with an adequate sorption capacity. Their general horizontal bedding promotes lateral spreading of moisture and retards downward transport of radionuclides.

Key Words: GEOLOGY AND HYDROLOGY Columbia River basalt, Hanford formation, Ringold Formation, stratigraphy, 200 Areas

$\mathrm{T}-2$

Tanner, T. M., R. C. Aldrich, G. R. Fox, B. E. Poremba, and D. N. Zweifel. 1984. Rockwell Hanford Operations Effluents and Solid Waste Burials During Calendar Year 1983. RHO-HS-SR83-1 P, Rockwell Hanford Operations, Richland, Washington. 37 p., App. A through C.

Abstract: Quantities of solid, liquid, or gaseous wastes buried or discharged on the Hanford Site during CY 1983 are reported as required by DOE Order 5484.1. Radioactive effluents are regulated by DOE limits and by Rockwell administrative controls based on DOE limits. No radioactive liquid or solid wastes were discharged off the site. Important events affecting the amounts of wastes generated, monitored, and ultimately discharged or disposed of include: 1) startup of the PUREX facility and new gaseous releases of radioactive krypton, carbon, iodine, and tritium vapor; 2) repairs on B Plant main stack ductwork, reducing gaseous ${ }^{8990} \mathrm{Sr}$ and ${ }^{13} \mathrm{Cs}$ releases by more than one order of magnitude over CY $1982 ; 3$ ) continued upgrading and additions to effluent sampling systems, and 4) decommissioning and decontamination activities, general cleanup, and increased production of nuclear materials, increasing radioactive and nonradioactive wastes more than $30 \%$.

Only one effluent (from PUREX) exceeded a DOE limit, the process condensate that contained excessive amounts of TRUs. Two other effluents exceeded Rockwell administrative control limits but were within DOE limits: 1) the B Plant process condensate stream discharged ${ }^{137} \mathrm{Cs}$ at 1.9 times and ${ }^{8980} \mathrm{Sr}$ at 798 times their concentration guides, and remedial plans were initiated; and 2) AY-AZ steam coil condensate exceeded guidelines for ${ }^{90} \mathrm{Sr}$ by a factor of 3.1 (this waste stream, which supported PUREX startup, was shut down in 3 days and modified to 
ensure compliance). Nonradiological airborne effluents, such as $\mathrm{NO}_{x}$ and $\mathrm{SO}_{\mathrm{z}}$, were all within required limits.

Key Words: EFFLUENTS AND WASTES - environmental monitoring, liquid effluents, gaseous emissions, PUREX plant, radioactivity, radioactive waste, regulatory compliance, waste generation, 200 Areas

\section{T-3}

Treat, R. L., R. O. Lokken, S. L. Stein, and C. A. Geffen. 1985. "Operational and Long-Term Performance for Hanford Grout." In Waste Management '85, Proceedings of the Symposium on Waste Management. Vol, 2, Waste Policies and Programs. Low-Level Waste, ed. R. G. Post, pp. 297-501. University of Arizona Press, Tucson, Arizona.

Abstract: The DOE and Rockwell are preparing construction of a transportable grout facility to immobilize selected radioactive liquid wastes now stored on the Hanford Site. Oak Ridge National Laboratory supports the program by developing the initial grout formulations. PNL is verifying operational characteristics of the grout formulation and evaluating longterm performance of the grouted waste form. Preliminary assessment of operational characteristics indicates that the grout form meets established criteria. Preliminary assessment of performance indicates that the grouted waste will provide longterm environmental protection. Laboratory and field tests are planned and ongoing for verification.

Key Words: EFFLUENTS AND WASTES - grout technology, grout treatment facility, radioactive waste management, remedial studies, waste treatment

$\mathrm{T}-4$

Trevathan, M. S., and K. R. Price. 1985. "Ambient Krypton-85 Air Sampling at Hanford." In Proceedings. Fifth DOE Environmental Protection Information Meeting, pp. 655-661. CONF-841187, Vol. 1., National Technical Information Service, Springfield, Virginia.

Abstract: In fall 1982, a network of continuous ${ }^{85} \mathrm{Kr}$ air samples was activated on and around the Hanford
Site. This effort responded to resumption of operations at a nuclear fuel reprocessing plant where ${ }^{85} \mathrm{Kr}$ would be released during fuel dissolution. EPA mobile gas samplers used in the preoperational effort functioned erratically, resulting in excessive maintenance costs, and prompted a search for a new sampling system. State-of-the-art ${ }^{85} \mathrm{Kr}$ sampling methods proved to be too costly, too complex, and unsuitable for field application, so a simple bag collection system was designed and field tested.

The new system consists of a reinforced, heavy plastic bag, connected to a variable flow pump and housed in a weatherproof enclosure. After 4 weeks of sampling, the air in the bag is transferred by a compressor into a pressure tank for transfer to the laboratory and analysis. The new system proved reliable and sensitive to ambient levels of ${ }^{85} \mathrm{Kr}$ over several months.

Key Words: RADIOACTIVITY - airborne radioactivity, environmental monitoring, krypton-85, sampling technique, 200 Areas

\section{U-1}

UNC Nuclear Industries, Inc. 1984. Assessment of Decommissioning Alternatives for Shut-Down Hanford 100 Area Reactors. UNI-2619, UNC Nuclear Industries, Inc., Richland, Washington. Irregular pages.

Abstract: Eight plutonium production reactors deactivated before 1971 are now maintained in a safe storage condition. The facilities and fuel storage basins cannot be abandoned because they would deteriorate and release radioactive materials to the environment. Three feasible decommissioning alternatives were identified and assessed: 1) in situ decommissioning, 2) safe storage/deferred dismantlement, and 3) immediate dismantlement. The alternative with the lowest cost, lowest occupational exposure usage, and shortest project duration is in situ decommissioning, a technique of demolishing above ground buildings and covering the area with clean fill and/or an engineered intrusion barrier. Assessment included site-specific pathway analysis, national requirements for radiological controls, and DOE dose limits that reflect the intent of NRC standards. Deferred dismantlement reflects 75 years of maintenance and surveillance and exposures 
occurring while waiting for high-energy, gammaemitting radionuclides to decay, plus costs of later dismantling. Immediate dismantlement reflects the high waste volumes involved, and special remote handling equipment and procedures required before the resident radionuclides decay.

Key Words: HANFORD SITE - alternatives assessment, environmental assessment, deactivated reactors, planning document, reactor decomissioning, 100 Areas

\section{U-2}

Uresk, D. W., and V. A. Uresk. 1980. Diets and Habitat Analyses of Mule Deer on the 200 Areas of the Hanford Site in Southcentral Washington. PNL2461, Pacific Northwest Laboratory, Richland, Washington. 21 p., App. A through C.

Abstract: Fecal pellets of mule deer from three areas on the Hanford Site contained 44 types of food. The most common plants eaten by deer were bitterbrush at the B-C cribs area, Russian thistle at B Pond, and goldenrod at Gable Mountain Pond. Similarity in diets among sites was low (10 to 16\%). Preference indices of forage plants among sites were not similar (7 to 19\%), indicating that deer selected different food plants at each site even though many plants were common to all sites. Habitats at the B-C cribs (12 species of plants), B Pond (12 species), and Gable Mt. Pond (22 species) were characterized for canopy cover and frequency of occurrence of plant species; similarities were low among sites. Overall, cheatgrass was the most common plant. Maximum levels of ${ }^{17} \mathrm{Cs}$ in deer pellet groups were $100 \mathrm{pCi} / \mathrm{g}$ at B Pond and $128 \mathrm{pCi} / \mathrm{g}$ at Gable Mt. Pond; background levels occurred at B-C cribs. Maximum levels of ${ }^{90} \mathrm{Sr}$ in pellet groups were $107 \mathrm{pCi} / \mathrm{g}$ at $\mathrm{B}$ Pond and $184 \mathrm{pCi} / \mathrm{g}$ at Gable Mt. Pond, indicating that mule deer take up radioactivity through forage plants at these sites.

Key Words: TERRESTRIAL ECOLOGY - bioaccumulation, B Pond, B-C cribs, food and feeding, forage plants, Gable Mt. Pond, mule deer, radioecology
U-3

URS/John A. Blume and Associates, Engineers. 1981. Geologic and Seismic Investigation of the Purex Building Site Near Richland. Washington. RHO-R-34, prepared for Vitro Engineering Corporation, Richland, Washington. $43 \mathrm{p}$.

Abstract: Regional geography was reviewed to reappraise methods used to develop ground-motion features at the PUREX Facility, 202-A Building, Hanford Site. Features included peak ground acceleration, response spectra, and acceleration-time history appropriate to the Hanford regional historic earthquake (HRHE). Seismic refraction surveys were conducted near PUREX to help determine preliminary soil dynamic properties.

The level of peak horizontal ground acceleration produced by the HRHE was a calculated $0.10 \mathrm{~g}$. Recommended response spectra and acceleration time history are given in the text. The response spectra is a mean-value spectrum that gives the expected HRHE ground motion frequency distribution; it is recommended for appraising the earthquake-resistance capacity of the existing PUREX building to postulated HRHE ground motions. The preliminary soil properties developed from seismic surveys are recommended for use in preliminary dynamic structural analysis.

Key Words: GEOLOGY AND HYDROLOGY ground motion, regional historic earthquake, PUREX Plant, response spectra, seismology, 200 Areas

U-4

U.S. Department of Energy. 1980. Final Environmental Impact Statement. Hanford Site. Double-Shell Tanks for Defense High-Level Radioactive Waste Storage. DOE/EIS-0063, U.S. Department of Energy, Washington, D.C. Irregular pages.

Abstract: The completion and operation of 13 storage tanks for high-level radioactive liquid waste on an interim basis were proposed. This EIS includes examination of design alternatives for tanks now under construction. Examination of alternatives complies with the September 29, 1979 directive of the U.S. District Court for the District of Columbia. 
The new facilities, now under construction in the 200 East Area of the Hanford Site, consist of 13 tanks capable of holding 1.0 million gal of high-level liquid wastes and their auxiliaries. Impacts of various design alternatives are addressed on the basis of tank durability, ease of waste retrieval, the choices for a technology to store radioactive waste for long-term and final disposal, as well as environmental concerns.

Key Words: HANFORD SITE - alternatives assessment, environmental impact statement, waste storage tanks, 200 Areas

\section{U-5}

U.S. Department of Energy. 1982. 316(a) Demonstration for Test of N Reactor in Plutonium-Only Mode of Operation. Richland Operations Office, U.S. Department of Energy, Richland, Washington. Irregular pages.

Contents: This document supports DOE's request to obtain alternative thermal effluent limitations for $\mathrm{N}$ Reactor, pursuant to Federal Water Pollution Control Act Amendments of 1972. Operation in the plutonium-only mode is rare, and the alternate limitations were requested only for a short time, December 1982 through March 1983. The site was described, a low impact rationale for all categories of aquatic biota except fish was established, representative important species (RIS) of fish were identified, the life histories of the RIS of fish were scoped, and the effects of N Reactor in a plutonium-only mode on RIS of fish were evaluated. Assessment indicated that RIS of fish would not be harmed while the reactor operated in a plutonium-only mode.

Key Words: HANFORD SITE - environmental assessment, fish entrainment (plume), $\mathbf{N}$ Reactor operation, representative important species (RIS) of fish, 316 (a) demonstration

\section{$\mathrm{U}-6$}

U. S. Department of Energy. 1982. Draft Environmental Impact Statement. Operation of PUREX and Uranium Oxide Plant Facilities, Hanford Site Richland. Washington. DOE/EIS-0089D, U.S. Department of Energy, Washington, D.C. Irregular pages.
Abstract: This EIS examines and compares the environmental impacts of reactivating the PUREX/UO, fuel processing facilities on the Hanford Site, and the impacts of alternatives to the proposed action. These facilities operated from 1956 to 1972 . Several modifications made since 1975 will reduce actual or potential impacts, as follows: Radionuclides (major fission products except tritium) in the process condensates discharged to the ground via cribs will be reduced to less than $50 \%$ of 1972 values; similarly, plutonium in liquid effluents discharged to cribs will be reduced from about $4 \mathrm{Ci} /$ year (detection limit) to an estimated $0.4 \mathrm{Ci} /$ year. Radionuclides in the ammonia scrubber wastes will be concentrated by distillation and stored in underground, double-shell tanks. The risk of theft or sabotage will be reduced by enhancing safeguards for special nuclear materials and improving plant protection. Recovery of ${ }^{85} \mathrm{Kr}$ gas from fuel dissolver gases is considered unnecessary because discharges and doses would be below applicable DOE guidelines.

The proposed action will increase the amount of acid waste (high-level liquid radioactive waste containing most fission products such as ${ }^{137} \mathrm{Cs},{ }^{90} \mathrm{Sr}$, etc.) to be managed at Hanford. This waste can be directly neutralized for interim storage, or the ${ }^{137} \mathrm{Cs}$ and ${ }^{90} \mathrm{Sr}$ in B Plant process waste can be recovered. Alternative actions are 1) construction of a new PUREX plant at Hanford, 2) process the fuel offsite, and 3) take no action. Radiological consequences from routine operations are expected to be less than $4.0 \%$ of the natural radiation dose ( $100 \mathrm{mrem} / \mathrm{year}$ ) regardless of the alternative selected.

Key Words: HANFORD SITE - alternatives assessment, envireonmental assessment, environmental impact statement, UO ${ }_{3}$ Plant, PUREX plant, PUREX/ $\mathrm{UO}_{3}$ startup, 200 Areas

U-7

U.S. Department of Energy. 1982. Site Characterization Report for the Basalt Waste Isolation Project. Vol, 1, 2, and 3. DOE/RL 82-3, U.S. Department of Energy, Washington, D.C. Irregular pages.

Abstract: The location for a repository to store nuclear wastes in basalt under the Hanford Site and its horizons have been identified. Preliminary characterization in support of the site screening 
process has been completed. This report gives results of the site screening process, the preliminary characterization data, the 15 technical issues that need to be addressed, and the plans for resolving these issues. The technical issues regarding site qualification will be resolved in the final site characterization report, planned for publication in 1987 , and in the safety analysis report to be submitted with the license application.

From geotechnical data now available, several conclusions are drawn about the basalts under the Hanford Site: 1) Flows more than $610 \mathrm{~m}(2,000 \mathrm{ft})$ below the surface are not subject to significant erosion, and are large and thick enough for a nuclear waste repository. 2) The calculated rate of deformation poses no threat to long-term integrity. 3) The sequence of basalt flows beneath Hanford is well understood and their depths are predictable. 4) The basalt rock, ground water, and materials to be deposited favor long-term stability. 5) The possibility of an adverse climatic impact is extremely low. 6) No faults have been identified that might adversely impact a repository. 7) The only resource now mined from the basalt is ground water pumped from shallow aquifers. 8) The location is well situated in regard to transportation, support and facilities, remoteness, and level terrain. 9) There is no land conflict with existing or planned facilities.

Key Words: HANFORD SITE - BWIP site, environmental assessment, geohyrologic data, geologic repository, reference repository location (RRL), site characterization

\section{U-8}

U.S. Department of Energy. 1983. Addendum to Environmental Impact Statement. Operation of PUREX and Uranium Oxide Plant Facilities. Hanford Site Richland. Washington. DOE/EIS-0089, U.S. Department of Energy, Washington, D.C. Irregular pages.

Contents: This addendum contains public comments received on the draft statement (DOE/EIS-0089D, see U-6), responses to the issues raised and changes or corrections to the draft statement for renewed operation of PUREX/UO ${ }_{3}$ plants. Textual changes were minor, and were noted on the errata sheets.
Key Words: HANFORD SITE - environmental assessment, environmental impact statement (EIS), $\mathrm{UO}_{3}$ Plant, PUREX Plant, PUREX/UO ${ }_{3}$ startup, 200 Areas

\section{U-9}

U.S. Department of Energy. 1984. Draft Environmental Assessment Reference Repository Location. Hanford Site. Washington. DOE/RW-0017, U.S. Department of Energy, Washington, D.C. Irregular pages.

Abstract: In February 1983, the DOE identified a location at Hanford as one of nine potentially acceptable sites for a mined geological repository to hold spent nuclear fuels and high-level radioactive wastes - the reference repository location (RRL). To determine suitability, all sites must be evaluated in accordance with General Guidelines for Recommendation of Sites for Nuclear Waste Repositories. This Environmental Assessment (EA) draft provides evaluations, is issued for public review and comment, but is preliminary. A final EA will be prepared when all input is received.

The RRL at Hanford is in the Columbia Plateau, one of five geologic settings considered for the first repository. On the basis of this report, Hanford was not disqualified under the guidelines and remained suitable for site characterization. The DOE proposes that Hanford be one of five sites suitable for characterization as a RRL. When evaluations were compared, Hanford was one of three preferred sites.

Key Words: HANFORD SITE - BWIP site, environmental assessment, geohydrologic data, geologic repository, reference repository location (RRL), site characterization

\section{U-10}

U.S. Department of Energy. 1984. Hanford Waste Management Technology Plan. U.S. Department of Energy, Richland Operations Office, Richland, Washington. Irregular pages, App. A.

Abstract: The Hanford Waste Management Technology Plan (HWMTP) is a companion document to the Hanford Waste Management Plan (HWMP). Its main 
purpose is to describe the technology that must be developed to close each technical issue identified in the HWMP. The issues addressed relate to disposal of single-shell tank wastes, contaminated soil sites, solid waste burial sites, double-shell tank wastes, encapsulated ${ }^{13} \mathrm{CsCl}$ and ${ }^{90} \mathrm{SrF}_{2}$, stored and new solid TRU wastes, and miscellaneous wastes such as contaminated sodium metal. High-priority issues include characterization of various wastes, development of vitrification and grout technology, control of subsidence in buried waste sites, and development of criteria and standards, including performance assessment of systems proposed for disposal of defense waste at Hanford. Schedules for resolving open issues and individual tasks are presented. The estimated total cost to close all identified technical issues is $\$ 294$ million (in 1985 dollars).

Key Words: HANFORD SITE - Hanford Waste Management Technology Plan, planning document, waste disposal sites

\section{U-11}

U.S. Department of Energy. 1986. Disposal of Hanford Defense High-level. Transuranic and Tank Wastes. Draft Environmental Impact Statement. Vols. 1,2, and 3. DOE/EIS-0113, U.S. Department of Energy, Washington, D.C. (302 p., 345 p., and 395 p., respectively.)

Contents: This initial (draft) EIS was prepared to provide environmental data relevant to: 1) final disposal of high-level, TRU, and tank wastes on the Hanford Site, and 2) any actions required in implementing waste disposal alternatives. Specifically evaluated are a Hanford waste vitrification plant, a transportable grout facility, a waste receiving and packaging facility, and any additional actions in terms of long-term environmental protection for waste generated at Hanford before 1979 as low-level waste but regarded differently now.

This EIS considers: 1) in-place stabilization and disposal, with isolation by protective and natural barriers; 2) geologic disposal, where most of the waste is exhumed and processed according to its classification and TRU waste is moved for storage at Carlsbad, New Mexico; 3) the reference alternative, where some classes of wastes are stored in a geologic repository and other classes are stabilized in place; and 4) "no disposal" (continued storage). Environmental impacts, both short-term and long-term, are generally low for all four alternatives. Due to recovery, processing, and shipping, the costs of a geologic repository are 4 to 6 times those of other alternatives. Costs for "no disposal" are lowest, estimated at $\$ 1.8$ billion for the first century and $\$ 1.3$ billion for each succeeding century.

Key Words: HANFORD SITE - alternatives assessment, environmewntal assessment, environmental impact statement (EIS), radioactive waste, waste disposal alternatives

\section{U-12}

U.S. Department of Energy. 1986. Draft Phase I Installation Assessment of Inactive Waste Disposal Sites at Hanford. Vols, 1 and 2. Richland Operations Office, U.S. Department of Energy, Richland, Washington. Irregular pages, App. A through $\mathrm{C}$.

Abstract: This report covers the first phase of an effort under CERCLA (1980), as emended, which provides for cleanup of hazardous substances from inactive waste-disposal sites. For the Hanford Site, it: 1) documents inactive disposal sites and inventories, 2) ranks disposal sites with the EPA's Hazard Ranking System (HRS) for sites with radionuclides, and 3) identifies the inactive sites needing characterization and monitoring in the second phase.

A total of 337 inactive waste-disposal sites were identified at Hanford. Natural properties, such as ion exchange qualities of the vadose zone and arid climate, have aided safe management of Hanford's wastes to date. Most sites (84\%) contain a mix of radionuclides and chemicals. The other sites contain either nonradioactive waste only (6\%), or primarily dilute radioactive wastes $(10 \%)$. Inactive waste sites do not appear to have contaminated ground water or surface waters at Hanford. Application of EPA's HRS and DOE's modified HRS placed only 81 sites above the point where further CERCLA action is required. A supplemental technical analysis was used to further classify inactive sites at Hanford, leaving only 62 sites for action in Phase II, pending further analysis and data.

Key Words: HANFORD SITE - environmental assessment, hazard ranking system, high-level 
radioactive waste, inactive waste sites, regulatory compliance, site characterization

\section{U-13}

U.S. Department of Energy. 1986. Environmental Assessment for the Grouting and Near-Surface Disposal of Low-Level Radioactive Phosphatel Sulfate Waste From N Reactor Operations. DOE/ EA-0312, U.S. Department of Energy, Washington, D.C. 52 p., App. A through C.

Abstract: Information is provided for a proposed action to solidify and dispose of a liquid, low-level radioactive waste generated by $\mathrm{N}$ Reactor on the Hanford Site. One component is a phosphate-based solution generated from decontamination work. The other is a sulfate solution resulting from regeneration of ion-exchange columns and backflushing sand filters. The proposed action is to solidify these wastes by mixing with cementitious dry materials to form a grout slurry. The slurry would be pumped to preconstructed, near-surface vaults in the 200 East Area to solidify. The vaults would be capped with 5 $\mathrm{m}$ of soil.

Releases from the waste disposal system and $\mathrm{mi}$ gration to the unconfined aquifer, as well as human intrusion scenarios, were evaluated to estimate the long-term performance of the proposed action. Radionuclide dose rates and chemical analyses were expected to be below regulatory limits. Nonradiological emissions and resource requirements would be low. Public health or environmental impacts would be insignificant.

Key Words: HANFORD SITE - environmental assessment, grout disposal process, low-level radioactive waste, $\mathrm{N}$ Reactor, planning document, waste disposal

\section{U-14}

U.S. Department of Energy. 1986. Environmental Assessment. Reference Repository Location. Hanford Site, Washington, 3 Vols. DOE/RW-0070, U.S. Department of Energy, Washington, D.C. Irregular pages.

Abstract: In February 1983, the DOE identified a reference repository location at the Hanford Site in
Washington as one of nine potentially acceptable sites for a geologic repository to hold spent nuclear fuel and high-level radioactive waste. The site was in the Columbia Plateau, one of five distinct hydrogeological settings considered for the first repository. To determine their suitability, the Hanford Site and eight other potentially acceptable sites were evaluated according to the DOE's General Guidelines for the Recommendation of Sites for the Nuclear Waste Repositories. Evaluations were reported in draft environmental assessments (EAs), which were issued for public review and comment. After considering the received comments, the DOE will prepare the final EAs.

On the basis of evaluations in this EA, the Hanford site was not disqualified under the guidelines for consideration as a geologic repository. It was also found suitable for site characterization because the evidence indicates that the site will meet each of the qualifying conditions specified in the guidelines. Therefore, the DOE is nominating the Hanford Site as one of five locations suitable for characterization.

Key Words: HANFORD SITE - BWIP site, environmental assessment, geohydrologic data, geologic repository, reference repository location (RRL)

U.S. Department of Energy. 1986. Hanford Environmental Management Program Plan. Environmental Compliance Task Force, U.S. DOE, Richland Operations Office, Richland, Washington.

Abstract: The Hanford Environmental Management Program (Program) uses a structured program/project approach to achieve environmental objectives, including compliance with the letter and spirit of applicable regulations. The Program Plan, a strategic-level planning document, states the policies, objectives, scope, and processes involved in implementing the Program. Chapter 1 presents the environmental management policy at Hanford. Chapter 2 describes key management elements and the roles of management organizations. Chapter 3 explains implementation at the technical level, including internal audits, regulatory inspections, peer reviews, and environmental monitoring. Chapter 4 explains procedures used to verify implementation at the technical level. Chapter 5 references the Hanford public information program. Chapter 6 explains 
acronyms used in the text. Chapter 7 gives applicable Federal, State and local regulations. The appendices provide the budgets, schedules, and references for detailed evaluation of specific facilities, operations, and necessary corrective actions.

Key Words: HANFORD SITE - Hanford environmental management program, planning document, regulatory compliance

\section{U-16}

U.S. Department of Energy. 1987. Implementation Plan for Hanford Site Compliance to DOE Order 5820.2. Radioactive Waste Management. DOE/RL87-15, U.S. Department of Energy, Richland Operations Office, Richland, Washington. 76 p., App. A through $\mathrm{C}$.

Contents: This plan is limited to management of radioactive hazardous waste as defined in DOE Order 5820.2 , issued February 6, 1984. It reviews the Order from two perspectives: 1) the compliance status of current waste treatment, storage, and handling practices in relation to the Order; and 2) impacts of compliance with the Order on proposed activities and planning for future waste disposal operations. This plan has six sections plus appendices. The sections concern requirements for management of: 1) high-level waste, 2) TRU waste, 3) lowlevel waste,4) naturally occurring radioactive waste, 5) decontamination and decommissioning of surplus facilities, and 6) response to DOE-RL control.

Key Words: HANFORD SITE - planning document, reactor decomissioning, regulatory compliance, waste management plan

\section{U-17}

U.S. Department of Energy. 1987. Disposal of Hanford Defense High-level, Transuranic and Tank Wastes, Final Environmental Impact Statement, Vols 1-5. DOE/EIS-0113, U.S. Department of Energy, Washington, D.C.

Contents: This final (revised) EIS examines potential impacts for alternatives to final disposal of existing defense wastes stored at Hanford since 1943 and of future wastes (those produced after October 1983). Existing and future wastes may be treated the same as wastes from commercial nuclear plants, but the older tanks, cribs, and burial sites at Hanford contain materials that may require special treatment and recovery.

For analysis, wastes under scope of this EIS fall in six classes. Specifically: 1) Existing Tank Wastes in both single-shell tanks (mostly solids) and doubleshell tanks (mostly liquids and suspended solids); 2)

Future Tank Wastes - wastes from PUREX after October 1983 to be stored in double-shell tanks; 3) Strontium and Cesium Capsules - in stainless steel or Hastelloy capsules stored underwater; 4) Retrievable and Newly Generated TRU Wastes - solid TRU waste produced since 1970, packaged, labeled, and stored pending final disposal; 5) TRU-Contaminated Soil Sites - soil contaminated by disposal of liquid waste in cribs, ditches, trenches, settling tanks, French drains, and injection wells; 6) Pre-1970 Buried Suspect TRU-contaminated Solid Wastes general trash and failed equipment buried in trenches before 1970 .

Five disposal alternatives were considered. In the first, Geologic Disposal, essentially all wastes are removed to a deep geological repository; low activity wastes are placed as grout in near surface vaults, high-level wastes are sent to a commercial repository, TRU wastes are sent to a Waste Isolation Pilot Plant (WIPP), and protective barriers and markers are installed. In the second, In-place Stabilization and Disposal, all wastes are stabilized in place and left at Hanford, and protective barriers and markers are installed. In the third, Reference (Combination Disposal), a combination of disposal methods was considered. In the fourth, the Preferred Alternative, essentially all present and future high-level wastes in double-shell tanks are sent to a commercial geologic repository, and the low-level fraction is placed as grout in near surface vaults. Encapsulated strontium and cesium wastes are sent to a commercial geologic repository. Retrievable and future TRU wastes are stored for disposal in the WIPP facility or, as an alternative, pre-1970 buried and suspect TRU waste (618-11 site) is sent to a geologic repository. Decisions on disposal of other wastes is deferred until additional development and evaluation. In the fifth, No Disposal Action (required, no-action alternative), waste storage continues but no disposal action is taken, and protective barriers and markers are not installed.

The rest of the report evaluates the short-term and long-term environmental impacts (judged to be low), 
short-term cumulative total-body radiation doses (judged small but some differences between disposal alternatives), protection of the general public (judged good for all alternatives except over the long-term for "No Disposal Action"), release of hazardous wastes and chemicals (contained or controlled), various scenarios resulting from human intrusion over time, and other aspects. In conclusion, all disposal alternatives have low environmental impact. Application of emended RCRA and CERCLA regulations to Hanford radioactive wastes is now beginning.

Key Words: HANFORD SITE - alternatives assessment, environmental assessment, environmental impact statement, high-level radioactive waste, lowlevel radioactive waste, planning document, regulatory compliance, waste management plan

\section{U-18}

U.S. Department of Energy. 1987. Environmental Survey Preliminary Report, Hanford Site. Richland, Washington. DOE/EH/OEV-05-P, U.S. Department of Energy, Office of Environmental Audit, Washington, D. C. Irregular pages.

Contents: Environmental problems and areas of environmental risk at DOE facilities were examined, via "no fault" baseline surveys, and ranked on a DOE-wide basis. Ranking is intended to help the DOE to establish priorities for addressing environmental problems and to address these problems. The survey at the Hanford Site was conducted by a multidisciplinary team of technical specialists, who carried out its activities in accordance with guidance and protocols in the DOE Environmental Survey Manual.

Findings were placed in four categories based on perceived risk. Category I includes only those findings that involve immediate threat to human life. Category II findings encompass a) multiple or continuing exceedances, past or present, of a healthbased environmental standard where there is immediate potential for exposing humans, b) evidence that a health-based standard may be exceeded, c) evidence that the likelihood is high for an unplanned release, or d) noncompliance with significant regulatory procedures. Category II includes environmental problems where the risk is high, but the definition of risk is broader than in Category I and more discretion is available for an appropriate response. Category III findings includes environmental problems for which the broadest definition of risk is used and, typically, will require lengthy investigation and remediation phases as well as multiyear budgets. Category IV findings include instances of administrative noncompliance and management practices that are indirectly related to environmental risk, but are not appropriate for including in Categories I to III.

Key Words: HANFORD SITE - onsite activities, planning document, regulatory compliance, risk assessment, risk at DOE facilities, site characterization

U. S. Department of Energy. 1987. Ground-Water Monitoring Compliance Projects for Hanford Site Facilities. Progress Report for the Period January 1 to March 31, 1987. Vol. 1: The Report. Prepared by Pacific Northwest Laboratory and Rockwell Hanford Operations for the U.S. Department of Energy, Richland, Operations Office, Richland, Washington. $66 \mathrm{p}$.

Abstract: This is the third status report (typical of this series) describing environmental monitoring at the 300 Area process trenches, the $183-\mathrm{H}$ solar evaporation basins, the 200 Area low-level burial grounds, and the non-radioactive dangerous waste (NRDW) landfill. During the 3-month reporting period, all monitoring wells part of the initial drilling phase were completed and included in monitoring networks at the 300 Area, 183-H, and NRDW landfill. Characterization reports were drafted for these sites. The 200 Area project was delayed because of the lack of bids for drilling. Analytical results produced no deviation from trends established by previous monitoring. The NRDW landfill has not impacted water quality in the area. Variations in wells at the 300 Area site are attributed to known activities. Variations in wells at the $183-\mathrm{H}$ facility are due to water table changes associated with river stages.

Key Words: EFFLUENTS AND WASTES - environmental monitoring, ground water, nonradioactive dangerous waste landfill, radioactivity, waste disposal sites, 183-H evaporation basins, 200 Areas burial grounds, 300 Area trenches 
routinely released to the soil at Hanford has been

U.S. Department of Energy. 1987. Hanford Waste Management Technology Plan. DOE/RL 87-14, U.S. Department of Energy, Richland Operations Office, Richland, Washington. Irregular pages.

Abstract: The Hanford waste management technology plan (HWMTP) is a companion document to the Hanford waste management plan (HWMP). Its purpose is to describe the technology that must be developed to close each technical issue identified in the HWMP, including costs and schedules. The technical issues relate to disposal of single-shell tank wastes, contaminated soil sites, solid waste burial sites, double-shell tank wastes, encapsulated ${ }^{19} \mathrm{CsCl}$ and ${ }^{\circ} \mathrm{SrF}_{2}$, stored and new solid TRU wastes, and hazardous/miscellaneous radioactive mixed wastes. High priority issues include characterization of the various wastes in underground tanks, contaminated soil sites, and solid-waste burial sites; development of stabilization and solidification processes required for final waste disposal; control of subsidence in buried waste sites; and development of criteria and standards for systems proposed for waste disposal at Hanford. Schedules for resolving open issues are given over an estimated span of 25 to 30 years. The estimated total cost to solve all identified technical issues is $\$ 678$ million.

Key Words: HANFORD SITE - Hanford waste management technology plan, planning document, waste disposal sites

\section{U-21}

U.S. Department of Energy. 1987. Plan and Schedule to Discontinue Disposal of Contaminated Liquids into the Soil Column at the Hanford Site. Richland Operations Office, U.S. Department of Energy, Richland, Washington. 43 p.

Abstract: Current DOE policy for managing radioactive waste requires that other techniques replace disposal directly to the environment or natural soil column. This report gives a plan and an implementation schedule for discontinuing release of contaminated liquids to the soil on the Hanford Site. The main radioactive substance in these wastes is tritium, which meets DOE's concentration guide at the site boundary without treatment. No liquid waste now designated as hazardous waste. The radiation dose to a hypothetical "maximum exposed individual" offsite, including discharges to the soil, was calculated to be $3 \mathrm{mrem}$ in 1985, well under offsite dose limits of $500 \mathrm{mrem}$ for occasional exposure and 100 mrem for prolonged exposure.

Alternative effluent treatments and disposal methods were examined by the DOE, and results are presented in this plan. A liquid effluent is suitable for disposal to the environment, including soil, if it meets criteria established in state and federal statutes. Technology to remove and dispose of tritium is not now available. Available alternatives for liquids containing tritium include direct discharge to the Columbia River, volatilization to the atmosphere, and discharge to the soil. Soil discharge is preferred because it results in the lowest offsite dose and is the lowest in cost.

Based on priorities, planned disposal of liquid effluents is two-phased. Phase I, for 16 of 32 discharges at Hanford, could be implemented with appropriate technologies by 1995 . Phase I would cost an estimated $\$ 120$ to 160 million in capital funds and $\$ 28$ million in support costs. Phase I includes new treatment for effluent from $\mathrm{N}$ Reactor, which could be implemented by 1989 and reduce total radionuclide discharges (other than tritium) to the soil by $98 \%$. Treating the effluent of three waste streams would reduce nitrates, the main chemical constituent in the waste, by $90 \%$. Phase II costs would range from $\$ 130$ to 200 million in capital costs and $\$ 23$ million in development or support costs. Estimated operating costs after implementation of Phase I and Phase II would be near $\$ 50$ million annually.

Key Words: HANFORD SITE - alternatives assessment, disposal to soil, planning document, regulatory compliance, waste disposal, waste management plan

\section{U-22}

U.S. Department of Energy. 1988. Environmental Field Activities Plans for the Hanford Site for Site Characterization. Draft. DOE/RW-0175, Basalt Waste Isolation Project, U.S. Department of Energy, Richland Operations Office, Richland, Washington. Irregular pages. 
Contents: This document was issued for BWIP and the reference repository location before work on the proposed geologic repository ended in late 1987. Separate chapters review rationale and plans to assess the environmental impact of BWIP on the Hanford environment. The six chapters are Air Quality, Archaeologial and Cultural Resources, Noise Monitoring, Radiation Monitoring, Terrestrial and Aquatic Ecosystems, and Water Quality. Planning for each effort includes study design, data management, schedule and milestones, organization and management, and quality assurance.

Key Words: HANFORD SITE - BWIP site, monitoring program, planning document, reference repository location

\section{U-23}

U.S. Department of Energy. 1988. Environmental Monitoring and Mitigation Plan for the Hanford Site for Site Characterization. Revision I. DOE/RW0172, Basalt Waste Isolation Project, U.S. Department of Energy, Richland Operations Office, Richland, Washington. Irregular pages.

Abstract: This is the Environmental Monitoring and Mitigation Plan (EMMP) developed to support BWIP and the reference repository location before the program ended in late 1987. The purpose of the EMMP is to identify monitoring programs that would detect any potentially significant impacts on the surrounding environment that might result from site characterization activities. The EMMP describes field investigations to establish geologic conditions of the site, the environmental monitoring studies to be conducted, and the process of developing mitigation alternatives, where applicable.

No potentially significant adverse impacts to land use, aesthetics, or transportation were anticipated from BWIP characterization activities. Potential impacts to terrestrial and aquatic ecosystems will result either from physical disturbance of the site or from increased human activity. Airborne contaminants are not expected to approach or exceed federal or state standards at the site boundary. Surface water quality is not likely to be impacted, but ground water quality might be affected and will be closely monitored. Soil will be affected by off-road vehicle use, and by construction of drill pad access road and facilities. Field noise will be monitored to ensure compliance with regulations, and to evaluate potential effects on habitat use by wildlife. No archaeological or historical resources at the site are on the National Register, or are eligible for listing, but evaluation and consultation will continue. Only minor impacts on existing radiological levels on or around the RRL are expected. Some activities might affect Native American cultural resources outside the $R R L$, and potential infringements of traditional religions or lifeways will be assessed.

Key Words: HANFORD SITE - BWIP site, environmental assessment, mitigation, monitoring program, planning document, reference repository location, site characterization

\section{$\mathrm{U}-24$}

U.S. Department of Energy. 1988. Final Status PostClosure Permit Application 183-H Solar Evaporation Basins. DOE/RL 88-09, prepared by Westinghouse Hanford Operations for U.S. Department of Energy, Richland Operations Office, Richland, Washington. Irregular pages, App. A through $\mathrm{C}$.

Contents: The DOE-RL intends to close the $183-\mathrm{H}$ solar evaporation basins under interim status. The Washington Administrative Code requires an interim status permit (submitted March 1988) pursuant to an application for a Final Status Post-Closure Permit. The basins are located in a potential inactive waste site and is a RCRA facility. Therefore, soil sampling, ground-water monitoring, waste removal, and cover design must be implemented in a way unlikely to affect any future remedial actions. Sections of this application describe 1) the facility and general provisions, 2) waste characteristics, 3) process information, 4) ground-water monitoring, 5) procedures to prevent hazards, 6) a contingency plan, 7) personnel training, 8) closure and post-closure requirements, and 9) other federal and state laws.

Key Words: EFFLUENTS AND WASTES planning document, radioactive waste, radioactive waste management, remedial assessment, $183-\mathrm{H}$ evaporation basins 
cost, potentially adverse socioeconomic conditions,

U.S. Department of Energy. 1988. Hazardous Waste Management Plan, Defense Waste Management. DOE/RL 88-01, U.S. Department of Energy, Richland Operations Office, Richland, Washington. 95 p., App. A through D.

Abstract: This plan identifies and tracks, for the DOE-RL, actions to achieve and maintain compliance of its facilities at Hanford with applicable regulations for the generation, transportation, treatment, storage, and disposal of hazardous wastes, including permit actions for inactive facilities. The approach is a seven-step process. Assessments to date indicate that handling of nonradioactive hazardous wastes meets most of all identified requirements. Establishing compliance in handling radioactive hazardous wastes (mixed wastes) requires that current practices be revised. The development and implementation of a formal waste minimization program, contingency and/or emergency plans, and training programs will establish compliance for waste generating facilities. Permit and other compliance actions are being implemented for the treatment, storage, and disposal facilities to meet both interim and final status requirements. Cost summaries are presented to the extent they have been identified and planned.

Key Words: HANFORD SITE - planning document, regulatory compliance, permit application,waste management plan

\section{U-26}

U.S. Department of Energy. 1988. Socioeconomic Monitoring and Mitigation Plan for the Hanford Site for Site Characterization. Revision I. DOE/RW0174, U.S. Department of Energy, Richland Operations Office, Richland, Washington. Irregular pages.

Abstract: This is the socioeconomic monitoring and mitigation plan (SMMP) developed to support BWIP and the reference repository location before the program ended in late 1987. The purpose of the SMMP is to describe monitoring and mitigation whenever a site characterization activity has potential to cause a significant adverse impact on socioeconomic conditions. The SMMP identifies major program components, the program work force and monitoring and mitigation programs, and services and facilities.

Site characterization will: require a work force of management, technical, and support service personnel; pay taxes and make Payments Equal to Taxes to state, county, and other government units; and involve extensive regulatory and institutional activities. Potentially significant impacts are evaluated for regional economy, demography, services and facilities (including housing), fiscal, and cultural. The SMMP includes only current data, which are subject to change with further decisions on program schedule and budget.

Key Words: HANFORD SITE - BWIP program, environmental assessment, mitigation, planning document, reference repository location, site characterization, socioeconomic

\section{U-27}

U.S. Department of Energy. 1988. U.S. Department of Energy - Richland Operations Office 1988 Biennial Waste Minimization Report. DOE/RL 8805, prepared by Westinghouse Hanford Company for U. S. Department of Energy, Richland Operations Office, Richland, Washington. $41 \mathrm{p}$.

Contents: This report addresses activities undertaken by the DOE/RL through contractors to reduce the volume and toxicity of waste generated on the Hanford Site. To the extent possible, waste minimization accomplishments are reported in quantitative terms. Although the concept and implementation of waste minimization at Hanford is relatively new, substantial reductions in the amount or toxicity of certain types of waste have been achieved. As the program progresses, the savings attributable to reduced waste disposal costs and improvements in operational efficiency will provide more incentives to reduce wastes needing disposal.

Key Words: HANFORD SITE - regulatory compliance, waste disposal, waste minimization effort

\section{U-28}

U.S. Department of Energy. 1988. 316(a) Demonstration for Operation of $N$ Reactor in a Dual-Purpose 
Mode. Draft. U.S. Department of Energy, Richland Operation Office, Richland, Washington. Irregular pages, 12 App.

Abstract: N Reactor is part of a dual-purpose facility on the Hanford Site that produces special nuclear materials and steam (at HGP) to generate electricity. It is cooled by Columbia River water, and the heated effluent is returned to the river. N Reactor's thermal discharge complies with national and permitspecified effluent limitation standards, but it exceeds water quality standards outside the mixing zone at certain times of the year.

This 316(a) Demonstration focuses on potential impacts to 10 representative important species (RIS) of fish and 5 RIS of shellfish and macroinvertebrates in the Hanford Reach. Other biotic categories studied in 1978 and 1982 were declared to be low-potential impact areas by the State Department of Ecology and the U.S. Environmental Protection Agency. This report determines that the 15 RIS considered would not be adversely affected by the thermal discharge from $\mathrm{N}$ Reactor during dual-purpose operation. Criteria and data leading to this conclusion are presented in the text and 12 appendices.

Key Words: HANFORD SITE - cooling water discharge, environmental assessment, $\mathrm{N}$ Reactor, $\mathrm{N}$ Reactor operation, representative important species (RIS) of fish, 316 (a) demonstration

\section{U-29}

U.S. General Accounting Office. 1988. Nuclear Waste. DOE's Handling of Hanford Reservation Iodine Information. GAO/RCED-88-158, Report to Congressional Requesters by U.S. General Accounting Office, Washington, D.C. 48 p.

Abstract: In August 1987, the DOE released information on ${ }^{129} \mathrm{I}$, a radioactive material in ground water beneath the Hanford Site. This information raised questions about the suitability of Hanford as a candidate site for a nuclear waste repository. Senator Mark Hatfield and Representatives Ron Wyden and Al Swift (all of Oregon) requested the GAO to learn why this information was not disclosed in a May 1986 environmental assessment. The GAO found that, generally, 1) studies on ${ }^{129}$ at Hanford were not well coordinated, concluded, or published; 2) concerns about security, real or perceived, had a role in nondisclosure of iodine-129 information because of questions on classification; and 3) the DOE did not use ${ }^{129} \mathrm{I}$ information in the environmental assessment because, as a matter of policy, unpublished information was not used. DOE maintains that its conclusions in the May 1986 environmental assessment would not change had the ${ }^{129}$ information been compiled and analyzed. Subsequently, Hanford was eliminated as a candidate site for a geologic repository.

Key Words: RADIOACTIVITY - Hanford Site, Hanford Site releases, iodine-129, onsite operations, radiation data, waste management

U-30

U.S. Geological Survey. 1987. Subsurface Transport of Radionuclides in Shallow Deposits of the Hanford Nuclear Reservation. Washington - Review of Selected Previous Work and Suggestions for Further Study. Open-File Report 87-222, U.S. Geological Survey, Denver, Colorado. 51 p., App. A through D.

Abstract: Estimates of radioactive contaminants reaching the Columbia River in ground water beneath the Hanford site, and the rates of ground-water movement from disposal sites, disagree. Travel rates are important mainly in relation to radioactive decay. In 1985-1986, a consulting firm based in Washington (SEARCH) concluded that ground-water discharges at Hanford were greater, and travel times were less, than estimated by the DOE contractor. The U.S. Geological Survey examined the analyses and data produced by SEARCH, and reached four conclusions. First, available data neither confirm nor refute the existence of a narrow, highly-permeable groundwater channel connecting the Hanford 200 East Area with the Columbia River, as postulated by SEARCH. Second, the streambank discharge from Hanford to a 852-ft reach of the river was, indeed, large but SEARCH's calculated release of $6.3 \mathrm{cfs}$ may have a large error. Third, a travel time of 2.5 years, as estimated by SEARCH, cannot be supported; travel time was more likely 10 to 20 years, but could be as low as 6 years. Fourth, SEARCH's estimate of the mean annual discharge of tritium in ground water may be high by a factor of three. The Survey's conclusions, as were those from SEARCH, were estimates based on incomplete and inconclusive 
evidence. Suggestions were made to obtain additional evidence on the hypothesized channel, groundwater discharge to the river, travel time estimates, and tritium discharges, and to use ground-water modeling.

\section{Key Words: GEOLOGY AND HYDROLOGY -} ground-water movement, Hanford Site, travel times, unconfined aquifer, U.S. Geological Survey assessment

\section{U-31}

U.S. Geological Survey and Performance Assessment Group (Rockwell Hanford Operations). 1981. 1981 Geodolite Observations Near Hanford, Washington. RHO-BW-CR-132 P, Rockwell Hanford Operations, Richland, Washington. 9 p., App. A and B.

Abstract: Repeated measures of strain accumulation at the Hanford Site over 9 years provided a quantitative measure of deformation. A low rate of strain accumulation was indicated. In 1981, the existing geodetic network was expanded to provide more detailed strain accumulation for the Snively Basin portion of the Rattlesnake Hills anticline and for the Wallula Fault system south and east of the Hanford Site. The observed direction of compression, N 85 degree $\mathrm{W}+/-14$ degrees, was inconsistent with most focal mechanism solutions in the area. The direction was consistent with a model for subduction of the Juan de Fuca Plate, but the observed rates were higher than predicted by such a model.

Key Words: GEOLOGY AND HYDROLOGY compression, deformation strain, geodetic network, Hanford Site, seismology

\section{V-1}

Van Luik, A. E., R. M. Mitchell, G. V. Last, R. C. Routson, D. S. Landeen, and K. R. Fecht. 1980. Characterization of the W-5 Burial Ground Expansion Site. RHO-CD-941, Rockwell Hanford Operations, Richland, Washington. $55 \mathrm{p}$.

Abstract: The ecology, hydrology, and geology of the W-5 Burial Ground Expansion site, located next to but west of the 200 West Area at Hanford, was characterized with available data. Ecological issues identified were closeness to U.S. Highway 240 , potential plant and animal intrusion, wind erosion potential for denuded areas, and the presence of measurable radionuclide contamination. The main hydrological issue was a potential for upward movement of radionuclides with the flux of water to and from the sediments, in response to precipitation and evapotranspiration. Geological issues were a steep slope across the upper one-third of the W-5 Expansion area, its dominant topographical feature; the presence of active dune areas that emphasize the potential for wind erosion; and the gravelly character of the higher, northern part of the site compared with the sandier sediments of its lower, southern part.

Key Words: EFFLUENTS AND WASTES - environmental assessment, geohydrologic issues, radioactive waste, remedial assessment, 200 Areas, W-5 burial grounds

\section{V-2}

Van Luik, A. E., and R. M. Smith. 1982. 216-S-1 and S-2 Mixed Fission Product Crib Characterization Study. RHO-ST-39, Rockwell Hanford Operations, Richland, Washington. 88 p., App. A through C.

Abstract: The 216-S-1/2 crib is an underground structure used for the disposal of contaminated liquid waste on the Hanford Site. The crib received acidic, intermediate level radioactivity in liquid solutions. About $1.6 \times 10^{8}$ liters of liquid containing about 7.5 $x 10^{-5}$ curies of mixed fission products entered the crib from 1952 to 1956.

Radionuclide distributions near the crib appeared to be stable, with no significant translocation since the late 1960 's. Most of the ${ }^{157} \mathrm{Cs}$ activity was restricted to a $10-\mathrm{m}$ zone beneath the crib 10 to $20 \mathrm{~m}$ from the surface, and was deepest beneath the S-2 portion. Historically, ${ }^{90} \mathrm{Sr}$ was widespread beneath the crib. In $1982,{ }^{90} \mathrm{Sr}$ was detected in two localized areas below the water table. One area was associated with a zone of contamination caused by the casing failure of a ground-water monitoring well within the crib in 1955; a similar cause was suspected but could not be confirmed for the other area.

Key Words: EFFLUENTS AND WASTES - environmental assessment, cesium, radioactivity, soil sorption, strontium, waste disposal, 216-S-1/2 crib, 200 Areas 
Abstract: Beneath a surface pattern of legal, political,

Veatch, M. D. 1980. Preliminary Subsurface Hydrologic Considerations: Columbia River Plateau Physiographic Province. PNL-2859, Pacific Northwest Laboratory, Richland, Washington. 43 p.

Abstract: Hydrologic conditions of the Columbia River Plateau (CRP) physiographic province are discussed. The CRP is underlain by a thick basalt sequence consisting of both basalt flows and sedimentary interbeds. The interbeds are the main aquifer zones. Permeable interflow zones also transmit water. Conceptually, the stratigraphic sequence from surface down contains the 1) unsaturated zone, 2) unconfined aquifer, 3) uppermost confined aquifer, and 4) lower Yakima basalt hydrologic sequence. The unsaturated zone consists of silt, sand, and gravel deposits, and is $<1 \mathrm{~m}$ to $>100$ $m$ thick; its moisture content is very low. The unconfined aquifer consists of sand and gravel resting on the Ringold Formation; its hydraulic characteristics are variable. The uppermost confined aquifer consists of the sands and gravels of the lower Ringold Formation, sedimentary interbeds, and permeable interflow zones; it is connected in places in the Pasco Basin with the overlying unconfined aquifer. The lower Yakima basalt hydrologic system consists of basalt flows and interbeds that underlie the Vantage Sandstone Formation. Hydraulic head relationships between the stratigraphic sequence are known only generally. Hydraulic gradient in the unconfined aquifer ranges from about 0.5 to $5 \mathrm{~m} / \mathrm{km}$ throughout the Pasco Basin. A conceptual layered earth model was developed that may provide better understanding of how hydrology may be changed as a result of disruptive events.

Key Words: GEOLOGY AND HYDROLOGY basalt formations, Columbia River Plateau, confined aquifer, hydraulic gradient, stratigraphy, unconfined aquifer

\section{W-1}

Walker, D. E., Jr. 1987. "Native American and Cultural Impact Analysis: The Proposed Nuclear Waste Repository at Hanford." In Waste Management '87, Proceedings of the Symposium on Waste Management. Vol, 2 High-Level Waste, ed. R. G. Post, pp. 123-124. University of Arizona Press, Tucson, Arizona. economic, and other formal structures, Native American reservations and their tribes possess many culturally distinctive values and patterns of life. Generally, Native American leaders wish to preserve and nourish this ancient culture. Their main objective is tribal survival, and theorys and methods of socioeconomic and cultural impact assessment must reflect this objective. Conventional impact analysis rarely meets the need of tribal leadership. Current fragmented approaches must be replaced by integrative, holistic alternatives.

Key Words: SOCIOECONOMICS - affected Indian tribes, BWIP, cultural values, Native Americans

\section{W-2}

Wallace, R. W., D. K. Landstrom, S. C. Blair, B. W. Howes, M. A. Robkin, G. L. Benson, A. E. Reisenhauer, W. H. Walters, and M. G. Zimmerman. 1980. Topical Report on Release Scenario Analysis of Long-Term Management of High-Level Defense Waste at the Hanford Site. PNL-3363, Pacific Northwest Laboratory, Richland, Washington. 93 p., App. A through F.

Contents: This report gives potential release scenarios for defense high-level waste ( $\mathrm{HLW}$ ) on the Hanford Site. It covers the three components necessary for evaluating various alternatives for longterm management of HLW: 1) scenarios and events that might disrupt radionuclide containment barriers, 2) geotransport calculations of waste migration through site media, and 3) consequence (dose) analyses based on ground-water and air pathways. Scenarios are categorized as bounding or nonbounding. Bounding scenarios consider "wórse case" or "what if" events, and include both near-term (first 100 years) and long-term. Nonbounding scenarios consider events that result in insignificant releases or no releases, even though they may disrupt the waste containment system.

Three release mechanisms were described: 1) direct exposure of waste to the biosphere by events such as drilling, with subsequent transport by wind or water; 2) contact of waste with the unconfined aquifer through downward movement of ground water or a rising water table; and 3) cataclysmic or explosive release of radionuclides. An attempt was 
made to identify events that could release radionuclides over 100 to 10,000 years. Development of "what if" scenarios can result in many imaginary ways that buried materials might be reintroduced to the biosphere, and even become concentrated. Proving any scenario is as impossible as disproving it.

Key Words: EFFLUENTS AND WASTES - highlevel waste (HLW), radioactive waste management, release scenarios, waste disposal/burial sites

\section{W-3}

Walter, M. B., M. J. Graham, and G. W. Gee. 1984. A Field Lysimeter Facility for Evaluating the Performance of Commercial Solidified Low-Level Waste. PNL-5253, Pacific Northwest Laboratory, Richland, Washington. 24 p., App. 1.

Abstract: A field lysimeter facility was established at Hanford to determine soil solutions surrounding a commercial, low-level waste site in an arid climate where the wastes were solidified with cement, a Dow polymer, and bitumen. This facility and its operation were described. Data collected include moisture release characteristics, particle size distribution, and distribution and concentration of radionuclides in the waste forms. The goal of combined laboratory and field efforts is to identify the mechanisms that control release of radioactivity.

Key Words: GEOLOGY AND HYDROLOGY lysimeter data, lysimeter facilities, soil characteristics, unsaturated (vadose) zone

\section{W-4}

Washington Public Power Supply System. 1982. Technical Review of the Aquatic Monitoring Program of WNP-2. Washington Public Power Supply System, Richland, Washington.

Abstract: The WPPSS evaluated the aquatic monitoring program for WNP-2 in response to the Energy Facility Site Evaluation Council Resolution. This report summarizes the data base obtained from 1974 to 1980 for each monitoring component (e.g. fish, benthos), examines the adequacy of the data for baseline purposes, considers the potential for any operational impact, and proposes future operational phase monitoring.

Evaluation indicated that an adequate preoperational baseline had been established, that some phases of monitoring would have better chance to detect operational impacts, should they occur, and that a continued but modified form of monitoring was needed. The Supply System recommended the: 1) continuation of periphyton, benthos, fish, and water quality monitoring, 2) addition of thermal plume, toxicity, and intake studies (as required by regulating agencies), and 3) deletion of phytoplankton and zooplankton studies.

Key Words: HANFORD SITE - environmental monitoring, Hanford Reach, monitoring program, site characterization, WNP-2, 400 Area

W-5

Washington Public Power Supply System. 1985. Operational Ecological Monitoring Program for Nuclear Plant 2, 1984 Annual Report. Washington Public Power Supply System, Richland, Washington. Irregular pages.

Abstracl: Results are presented from ecological monitoring near WNP-2 during March 1983 through October 1984 (preoperational), and on through December 1984. The effort provides a data base for identifying long-term trends and possible operational impacts related to aquatic ecology, water quality, and terrestrial ecology.

Benthic microfauna remained unchanged by WNP2 operation. Benthos density and biomass were highest in summer, lowest in winter. Periphyton biomass were comparable before and after plant operation, usually low in spring and high in summer and fall. No fish impinged on the intake screens, and fouling was normal (insects and algae). An October 1984 bioassay with juvenile chinook salmon in cooling tower water resulted in no mortality after 96 hr. Water quality in the Columbia River during 1983-1984 met Washington State Class A standards, and HGP-2 operation apparently had no effect. Because of a range fire and cold spring, the number and density of bird species were lower than previous 
years. Deer were most abundant in the south shrub area during spring and fall surveys, and rabbits were most abundant in shrub areas to the north and south. Herbaceous vegetation was dominated by cheatgrass, and grassland sites held lower herbaceous phytomass than shrub sites. Sulfate, chloride, and copper levels in plants were relatively consistent from 1980 through 1984.

Key Words: HANFORD SITE - aquatic biota, environmental monitoring, Hanford Reach, soil and vegetation, WNP-2, WNP-2 operation, water quality, wildlife, 400 Area

\section{W-6}

Washington Public Power Supply System. 1986. Operational Ecological Monitoring Program for. Nuclear Plant. 2. 1985 Annual Report. Washington Public Power Supply System, Richland, Washington. Irregular pages.

Abstract: Results are presented from ecological monitoring near WNP-2 on the Hanford Site in 1985. The effort provides a data base for identifying longterm trends and possible operational impacts related to aquatic ecology, water quality, and terrestrial ecology.

Density and biomass of benthic macrofauna increased over 1984. Chironomidae (midge fly larvae) and Hydropschidae (caddisfly larvae) accounted for $86 \%$ of the organisms and $67 \%$ of the biomass. WNP-2 operations caused no measurable changes in benthic fauna or periphyton. Water quality in the Hanford Reach satisfied state Class A standards for the values measured, but some changes occurred in the effluent mixing zone during March and April. No fish were impinged, nor were fish, fish eggs, or larvae detected in entrainment samples. The intake screens did not foul significantly. Juvenile steelhead trout and chinook salmon underwent no mortalities when they drifted through the thermal plume. The Asiatic clam was not a hazard to the plant cooling system. Bioassays with discharge effluent resulted in no mortality among juvenile rainbow trout or chinook salmon. Three-dimensional thermal measurements were made of the discharge plume on four occasions.

One year after commercial operation, 17 chemical values remained similar to preoperational values.
However, conductivity increased markedly and $\mathrm{pH}$ decreased slightly at three sites near WNP-2's cooling towers. Copper, sulfate, and chloride concentrations in tissues of six plant species remained unchanged. Four species of birds accounted for $47 \%$ of all birds observed during spring and fall surveys. Deer were most abundant in shrub and riparian biomes, and rabbits in the shrub biome south of WNP-2.

Key Words: HANFORD SITE - aquatic biota, environmental monitoring, Hanford Reach, soil and vegetation, WNP-2, WNP-2 operation, water quality, wildlife, 400 Area

W-7

Washington Public Power Supply System. 1987. Operational Ecological Monitoring Program For Nuclear Plant 2 - 1986 Annual Report. Washington Public Power Supply System, Richland, Washington. Irregular pages.

Abstract: Two years of operational data have revealed no effect from operation of HNP-2 on the density or biomass of benthic macro-invertebrates within the mixing zone, $42.7 \mathrm{~m}(140 \mathrm{ft})$ downstream of the cooling water discharge. As in past years, periphyton biomass was high in the winter and low in the spring and no effect was apparent from plant operation. No significant interstation differences could be detected in water quality values for nearly all sampling periods. With one exception ( $\mathrm{pH}$ values at all stations including the control on May 13, 1966), measurements were within water quality standards for Class A waters both above and below the effluent mixing zone. Underwater surveys of the cooling water intake structure in April and October revealed no impingement of fish.

Inspections of the tower makeup pump pit, the circulating water pumphouse, and the main condenser water boxes showed the invasive Asiatic clam only in the pump pit. The biofouling program at WNP- 2 is providing adequate control. Trace metal analysis of soil and vegetation were usually within the range reported in previous studies. Levels of copper in the soil at five stations, and nickel in the soil at three stations, exceeded preoperational ranges. Herbaceous cover, density, and phytomass showed more signs of recovery from the 1984 range fire at most stations. Cover continues to decline at unburned 
Station GO3, which is the closest to the cooling tower. Populations of birds, deer, and rabbits within study areas around WNP-2 remained stable.

Key Words: HANFORD SITE - aquatic biota, environmental monitoring, Hanford Reach, soil and vegetation, WNP-2, WNP-2 operation, water quality, wildlife, 400 Area

\section{W-8}

Washington Public Power Supply System. 1988. Operational Ecological Monitoring Program for Nuclear Plant 2 - 1987 Annual Report. Washington Public Power Supply System, Richland, Washington. Irregular pages.

Abstract: A long-term environmental monitoring program was adopted for WNP-2 in September 1987 when Resolution No. 239 was approved by the Energy Facility Site Evaluation Council. No significant environmental events occurred in 1987 from operation of WNP-2. As a result of Resolution No. 239, all animal studies were terminated. Spring 1987 studies with birds, deer, and rabbits indicated stable populations and no effect from WNP-2 operation. The cooling water discharge had little effect on water quality, and all measurements were within water quality standards for Class A waters.

Wide between-year fluctuations in herbaceous cover and density since monitoring began at WNP-2 can be explained by seasonal variations in precipitation and temperature, or by range fires. Mean phytomass production increased at all stations except SO4, indicating further recovery from the 1984 range fire. Phytomass averaged $95.8 \mathrm{~g} / \mathrm{m}^{2}$ at grassland stations and $101.4 \mathrm{~g} / \mathrm{m}^{2}$ at shrub stations. Concentrations of most chemicals were either within previously measured ranges or below levels measured in preoperational studies. No trends or adverse impacts could be identified from operation of WNP-2. An underwater survey in December showed no impinged fish and no significant fouling; the riverbed appeared to be stable. The biofouling effort appears to be controlling populations of the Asiatic clam.

Key Words: HANFORD SITE - aquatic biota, environmental monitoring, Hanford Reach, soil and vegetation, WNP-2, WNP-2 operation, water quality, wildlife, 400 Area
W-9

Waters, E. D. 1988. Consideration of Disposal Alternatives for Tritium-Contaminated Wastewater Streams at Hanford. WHC-EP-0118, Westinghouse Hanford Operations, Richland, Washington. 45 p., App. A.

Abstract: Environmental monitoring shows that tritium in air and water used by the public off the Hanford Site, and the total dose to the public, are well below established standards. However, tritium in the PUREX process distillate discharge is about 5,000 times the EPA's drinking water standard. Reducing tritium in the distillate to drinking water standards would require separation of $7.2 \mathrm{~g}$ of tritiated water from $10^{-8} \mathrm{~L} / \mathrm{yr}$ of condensate, leaving less than $0.0002 \mathrm{~g}$ of tritiated water in this effluent.

Physical/chemical processes with promise for removing tritium, in order of increasing cost, were 1) water-hydrogen sulfide gas exchange, 2) cryogenic distillation of hydrogen/tritium, 3) vacuum fractional distillation, and 4) electolysis and catalytic exchange. Each process, except for vacuum distillation, would require extensive pretreatment of the feed liquid and entail long-term costs for storage and monitoring of retained tritium. Overall costs would be more than 1,000 times greater than NRC guidelines for cost effectiveness of public dose reduction for commercial reactors.

Other alternatives to present soil column disposal of tritium streams include: 1 ) direct discharge to Columbia River, 2) well injection to a deep aquifer, and 3) decomposition of gaseous tritium, or evaporation and discharge via stack to the atmosphere. Deep well injection is the least costly option, but would likely encounter public and institutional resistance. Discharge to the river would increase short-term population radiation dose equivalents, but they would still be below allowable limits or guidelines. Stack discharge would likely lower the effective dose to the maximally exposed individual, but would not be a significant benefit because the present dose commitment from Hanford tritium is so low. Based on this study, there is no available technology that can be applied to tritium management at the Hanford Site to provide significant environmental benefit over past practice. 
Key Words: EFFLUENTS AND WASTES - alternatives assessment, PUREX Plant, radioactive liquids, radioactive waste management, tritium, waste disposal/treatment

\section{W-10}

Watson, E. C., C. D. Becker, R. E. Fitzner, K. A. Gano, K. L. Imhoff, R. F. McCallum, D. A. Myers, T. L. Page, K. R. Price, J. V. Ramsdell, D. G. Rice, D. L. Schreiber, L. A. Skumatz, D. J. Sommer, J. J. Tawil, R. W. Wallace, and D. G. Watson. 1984. Environmental Characterization of Two Potential Locations at Hanford for a New Production Reactor. PNL-5275, Pacific Northwest Laboratory, Richland, Washington. Irregular pages, App. A through F.

Contents: Two areas on the Hanford Site were environmentally described as potential locations for a new plutonium-production reactor (NPR). Possible impacts of locating a NPR at either site were not assessed. Environmental characterization covered eight subject areas in chapters entitled: geography and demography, ecology, meteorology, hydrology, geology, cultural resources, economic and social conditions, and effluents and environmental monitoring. To the extent possible, the most recent topical information was used. Supplemental data were provided in appendices.

Key Words: HANFORD SITE - generic information, new production reactor, site characterization

\section{W-11}

Waugh, W. J. 1988. Field Study of Gravel Admix. Vegetation, and Soil Water Interactions: A 1987 Status Report. PNL-6616, Pacific Northwest Laboratory, Richland, Washington. Irregular Pages, App. A through E.

Abstract: Protective barriers are being developed to isolate radioactive waste buried near the surface of the Hanford Site. The conceptual design includes a fine-textured topsoil that stores rainwater until it can be cycled back to the atmosphere by evapotranspiration. However, topsoil erosion may permit drainage through the buried waste and into ground water. Mixing of gravel into the surface layer has been proposed to create a self-healing veneer, analogous to desert pavements that preserve underlying soils intact for thousands of years.

A factorial field-plot experiment was set up, and changes in soil water storage and plant cover were monitored. First-year results suggest that extraction of water by plants will offset gravel-induced increases in soil storage of water. Without vegetation, the water content of soil near the surface was much higher in plots with gravel. With vegetation present, gravel had no effect on the water content of soil. Large variability in deep soil water storage masked any effect gravel may have on water below the root zone. Unexpectedly, plants were not more abundant on graveled plots, even though more water was available. Also, of the mixture of shrubs and grasses seeded, no shrubs emerged during the initial growing season.

Key Words: EFFLUENTS AND WASTES - buried waste, buried waste subsidence, radioactive waste, remedial studies, waste disposal

\section{W-12}

Waugh, W. J., and M. G. Foley. 1989. Protective Barrier Climate-Change Impacts: Technical Workshop Findings and Task Plan. PNL-6615, Pacific Northwest Laboratory, Richland, Washington. Irregular pages.

Abstract: PNL and WHC convened a workshop in January 1987 to define key issues regarding the effects of climatic variability on the performance of protective layered soil and rock barriers, proposed for possible use at Hanford. Workshop participants concluded that the sensitivity of vegetation and evapotranspiration to climate must be better understood before climate-change effects on drainage through barriers and ground-water recharge can be adequately modeled. As a result, participants proposed measuring evapotranspiration and other water balance features in lysimeters constructed around monoliths of undisturbed soil and mature vegetation, and located at sites analogous to lateQuaternary pluvial and altithermal conditions. Climate-analog sites would be selected based on reconstructions of late-Quaternary vegetation and model projects of future climatic variability in the 
region. The lysimeter data would be input to a simulation model of soil-water movement in barriers over buried waste sites. The distribution of pedogenic carbonates and radionuclides from atmospheric fallout would be analyzed as independent indicators of past water movement in analog-site soil profiles.

Key Words: EFFLUENTS AND WASTES - buried waste, buried waste subsidence, radioactive waste, remedial studies, soil barriers, waste disposal

\section{W-13}

Weber, H. W., and R. E. Fitzner. 1986. "Nesting of the Glaucous-Winged Gull East of the Washington Cascades." Am. Birds 40:567-569.

Abstract: A pair of glaucous-winged gulls nested on Island No. 18 in the Hanford Reach above Richland in June 1982 among large nesting colonies of ring-billed and Califomia gulls. Since 1954, this species has become a regular winter visitor in small numbers, but has not been known to breed here.

Key Words: TERRESTRIAL ECOLOGY - habitat use, Hanford Reach, nesting, gulls

\section{W-14}

Weeks, D. C., S. P. Luttrell, and M. R. Fuchs. 1987. Interim Hydrogeologic Characterization Report and Groundwater Monitoring System for the Nonradioactive Dangerous Waste Landfill, Hanford Site. Washington. WHC-EP-0021, Westinghouse Hanford Company, Richland, Washington. 57 p., App. A through $\mathrm{G}$.

Abstract: Hydrogeologic characteristics and installation of ground water monitoring wells are documented at the nonradioactive dangerous waste (NRDW) landfill. Nine wells were installed to examine ground-water quality, hydraulic conductivity, continuity of hydrostatigraphic units, and other features. Seven of these wells compose a detectionlevel, ground-water monitoring system that meets the requirements for interim status ground-water monitoring under 40 CFR 265, Subpart F.

Ground-water flow is generally west to east across the NRDW landfill, and the gradient is very small (about $0.1 \mathrm{ft} / 1,300 \mathrm{ft}$ ). The uppermost section of the aquifer is unconfined and highly transmissive. Transmissivity values range from about 100,000 to $300,000 \mathrm{ft}^{2} /$ day. Hydraulic conductivity ranges from 1,700 to $5,000 \mathrm{ft} /$ day, based on a saturated thickness of $60 \mathrm{ft}$. A relatively thin, clayey silt of low permeability is laterally continuous under the NRDW landfill, and acts as the base of the aquifer for the purpose of monitoring potential vertical migration of contaminants. Water samples from monitoring wells showed no violation of interim primary drinking water standards.

Key Words: GEOLOGY AND HYDROLOGY ground-water movement, hydraulic conductivity, nonradioactive dangerous waste (NRDW) landfill, transmissivity

\section{W-15}

Weiss, R. L. 1985. "Ion Exchange Recovery and Purification of Strontium-90 From Certain Hanford Waste Streams." In Waste Management ' 85, Proceedings of the Symposium on Waste Management. Vol, 1 High-Level Waste, ed. R. G. Post, pp. 569-

573. University of Arizona Press, Tucson, Arizona.

Abstract: A cation exchange process was developed to selectively remove and purify ${ }^{\circ} \mathrm{Sr}$ from a waste stream containing large amounts of lanthanide group and metallic ion impurities. The process was based on 1) selective complexation of lanthanides and metallic cations to inhibit their exchange, and 2) purification of the exchanged ${ }^{\circ} \mathrm{Sr}$ by elution of other impurities. More than $90 \%$ recovery of ${ }^{\circ 0} \mathrm{Sr}$ has been shown, with the recovered product essentially free of impurities. The process was scaled up to an $8.5 \mathrm{~m}^{3}$ production column and used to process about $3 \mathrm{MCi}$ of ${ }^{\circ} \mathrm{Sr}$. Production to date was consistent with laboratory data, except for a slight lowering of purity.

Key Words: EFFLUENTS AND WASTES - cation exchange recovery, liquid effluents, remedial studies, strontium, waste treatment

W-16

Westinghouse Hanford Company. 1987. Data Compilation: Iodine-129 in Hanford Groundwater. WHCEP-0037, Westinghouse Hanford Company, Richland, Washington. Irregular pages. 
Abstract: Iodine-129 occurs at ultratrace levels in nature and has been man-made since 1944. It is a mobile, long-lived radionuclide and a good tracer of ground water movement. Iodine- 129 is regulated by various agencies whose standards are generally not exceeded at the Hanford Site. This report summarizes all data and information about ${ }^{129} \mathrm{I}$ in ground water under Hanford, and covers the years 1959 to 1986. Over this period, water samples were taken for many reasons and in many ways. Some of the methods may have invalidated the analytical results, and caution is needed to avoid misleading and erroneous conclusions based on data in this compilation. The occurrence and potential sources of ${ }^{129} \mathrm{I}$ in subsurface waters at Hanford are discussed, and recommendations for site characterization planning are given.

Key Words: RADI0ACTIVITY - Hanford Site, ground water transport, historical review, iodinc-129, unconfined aquifer

\section{W-17}

Westinghouse Hanford Company. 1988. Best Available Technology (Economically Achievable) Guidance Document for the Hanford Site. WHC-EP0137, Westinghouse Hanford Company, Richland, Washington. 31 p., App. A.

Abstract: Disposal of liquid effluents on the Hanford Site now complies with DOE orders that protect public health and safety and, to the extent possible, minimize adverse impacts on the environment. Determination of Best Available Technology (BAT) on a liquid effluent will occur after the effluent meets all applicable release limits. Application of BAT may involve an additional level of control, as well as contribute to the As Low As Reasonably Achievable (ALARA) program.

BAT determination involves five steps: First, assemble all relevant liquid effluent data. Second, determine BAT by the effluent guidelines method. Third, in the absence of relevant guidelines, determine BAT by the technology transfer method. Fourth, in the absence of applicable technology transfer, determine BAT by the treatability studies method. Fifth, if all else fails to establish BAT, use the generic treatment system method to identify a range of potentially applicable and acceptable treatments. Two methods are presented for determining economic feasibility. Pollutants addressed under this BAT procedure have not been regulated under traditional state and federal water-pollution control programs.

Key Words: EFFLUENTS AND WASTES ALARA concept, BAT (Best Available Technology) concept, liquid effluents, Hanford Site, waste disposal/treatment, radioactive liquids, radioactive waste management

W-18

Westinghouse Hanford Company. 1988. Hanford Environmental Management Program Implementation Plan. WHC-EP-0180, Westinghouse Hanford Company, Richland, Washington. Irregular pages.

Contents: The Hanford Environmental Management Program (HEMP) was established to facilitate compliance of DOE-RL with applicable environmental statutes, regulations, and standards on the Hanford Site. The basic objectives are: 1) to establish ongoing monitoring to ensure compliance, 2) modify activities to ensure compliance, 3) mitigate any environmental consequences, and 4) minimize environmental impacts of future operations. Two separate organizational roles were identified to implement HEMP. WHC is responsible for environmental operations, and for controlling and monitoring releases to the environment. PNL, the research and development contractor, is responsible for monitoring the environment and evaluating the environmental impacts of operations at Hanford.

This implementation plan addresses the role assigned to WHC. It is divided into eight activity phases for effective management: 1) integrated environmental, 2) gaseous effluent, 3) liquid effluent, 4) solid waste, 5) toxic and hazardous material use, 6) inactive site, 7) environmental monitoring and reporting, and 8) environmental data resources.

Key Words: HANFORD SITE - contractor responsibilities, Hanford Environmental Management Program, planning document, regulatory compliance 
W-19

Westinghouse Hanford Company. 1988. Information on Hanford Site Cribs and Septic Systems. DOE/RL 88-19, U.S. Department of Energy, Richland Operations Office, Richland, Washington. Irregular pages.

Contents: This document identifies each crib and septic system on the Hanford Site with a design capacity of more than $14,500 \mathrm{gal} / \mathrm{d}$. The following information is given for each site: site name, location, service date, status, waste history, and physical description.

Key Words: EFFLUENTS AND WASTES - cribs (Hanford Site), septic systems, waste disposal sites

W-20

Westinghouse Hanford Company, 1988. Properties and Environmental Impact of Ammonia Scrubber Discharge Waste to the 216-A-36B Crib. WHC-EP0100, Westinghouse Hanford Company, Richland, Washington. 27 p., 1 App.

Abstract: Review of potential waste components at the Hanford Site indicated that ammonia scrubber distillate (ASD) contained reportable levels of ammonium hydroxide $\left(\mathrm{NH}_{4} \mathrm{OH}\right)$. Amounts in the ASD waste stream exceeded the federal CERCLA reportable quantity of $1,000 \mathrm{lb} / \mathrm{d}$ by a factor of about four. Peak concentrations exceeded Washington State's dangerous waste threshold level of $1 \%$ (Class $\mathrm{C}$ toxic substance), resulting in the stream being classified as a dangerous waste. Due to biological conversion of ammonia, nitrite, and nitrate levels in ground water were predicted to be $320 \mathrm{ppm}$ at the crib boundary, exceeding the drinking water standard of $45 \mathrm{ppm}$ (even though ground water beneath the crib is not used for drinking). The only component of environmental concern in the waste stream was nitrate. The PUREX processes that generated the waste to the 216-A-36B crib were discontinued and responsible agencies were notified.

This report provides data to evaluate the environmental effects of ASD. Vadose zone and ground water models were used to predict waste component transport as a function of waste composition, $\mathrm{NH}_{4}{ }^{+}$ biological conversion to $\mathrm{NO}_{2}^{-}$and $\mathrm{NO}_{3}^{-}$, soil sorption of $\mathrm{NH}_{4}^{+}, \mathrm{NH}_{3}$ volatilization, and time. Data from
ASD characterization were used with laboratorymeasured $\mathrm{NH}_{4}^{+}$conversion and sorption values, derived volatilization values, and unsaturated flow and ground water transport values as input to the models. Environmental effects were assessed at the crib boundary, the future control zone boundary ( 2 $\mathrm{km}$ from the crib), and the Columbia River. If the 216-A-36B crib was leached with uncontaminated water at the same rate as the ASD waste stream, nitrate levels were predicted to remain essentially constant for 75 days, and slowly drop to background levels the following 30 days.

Key Words: EFFLUENTS AND WASTES - ammonium hydroxide, environmental assessment, liquid effluents, nitrate, remedial studies, 216-A-36B crib, 200 Areas

W-21

Whelan, G., D. W. Damschen, and R. D. Brockhaus. 1987. Columbia River Statistical Update Model Version 4.0 (COLSTAT4); Background Documentation and User's Guide. PNL-6041, Pacific Northwest Laboratory, Richland, Washington. 75 p., App. A through $\mathrm{F}$.

Abstract: PNL developed a computerized data base to assess trends or changes in conditions downstream of Priest Rapids Dam, using data taken at Priest Rapids Dam and Vernita Bridge. Daily-averaged temperature and flow information was collected and stored in the data base. Flow data represent daily discharges from October 1, 1959 through July 28, 1986, and temperature data represent daily discharges from January 1, 1965 through May 27, 1986. The computer model, COLSTAT4 (Columbia River Statistical Update - Version 4.0), uses the temperature/discharge data base to statistically analyze temperature and flow conditions. The model analyzes the information in a sequential time frame (i.e., a continuous analysis over a given time; it also analyzes the information in a seasonal time frame (i.e., a periodic analysis over a specific season from year to year). A provision is included to enable the user to edit and/or extend the data base.

Key Words: HANFORD SITE - COLSTAT4 model, flow and temperature data, Hanford Reach 
W-22

Wheeler, R. E., and A. G. Law. 1980. Rockwell Hanford Operations Environmental Surveillance Report for Calender Year 1979. RHO-LD-132, Rockwell Hanford Operations, Richland, Washington. $97 \mathrm{p}$.

Abstract: Ambient radiation levels and radionuclide concentrations in uncontrolled parts of the 200 Area, except for some locations near waste handling and processing facilities, were in compliance with applicable DOE and Rockwell guidelines during 1979. A few sites near tank farms, burial grounds, and operating facilities, had surface contamination that exceeded guidelines, and were posted as radiologically controlled areas. Ambient radiation and radionuclide concentrations inside the 200 Areas were generally indistinguishable from background levels. Measurements were made of radionuclides in air, water, soil and sediments, vegetation, and animal feces, and of external radiation. Routine radiological surveys were made on roads and surfaces of waste disposal site.

Key Words: HANFORD SITE - environmental monitoring, radioactivity, regulatory compliance, 200 Areas

\section{W-23}

Wilbur, J. S., M. J. Graham, and A. H. Lu. 1983. Results of the Separations Area Ground-Water Monitoring Network for 1982. RHO-RE-SR-83-24P, Rockwell Hanford Operations, Richland, Washington. 152 p., App. A through G.

Abstract: During 1982, 107 wells were monitored in the Separations Area. Water levels were measured in additional wells before PUREX operations restart in fall of 1983 (after 12 years of standby). A calibrated ground-water flow model was prepared from this baseline to predict future impacts of an increased discharge.

Tritium levels exceeded $300 \mathrm{pCi} / \mathrm{mL}$ ( $10 \%$ of DOE Order 5980.1, Chapter XI guidelines) in wells at three active disposal sites: $216-\mathrm{A}-10,216-\mathrm{A}-36 \mathrm{~B}$, and 216A-37. Nitrate exceeded $45 \mathrm{mg} / \mathrm{L}$ (EPA drinking water standards) at two active sites: $216-\mathrm{A}-10$ and 216-A-36B. With the exception of tritium, radioactive contaminations $\left({ }^{90} \mathrm{Sr}\right.$ and $\left.{ }^{137} \mathrm{Cs}\right)$ that exceeded
$10 \%$ of DOE guidelines were at inactive waste disposal sites. Zones of contamination appeared to be localized near the inactive sites. Contamination levels in ground water leaving the Separations Area were less than DOE guidelines.

Key Words: HANFORD SITE - environmental monitoring, ground water, hazardous materials, radioactivity, regulatory compliance, 200 Areas

\section{W-24}

Wilbur, J. S., L. S. Prater, and P. A. Eddy. 1983. "Ground-Water Monitoring Programs at the Hanford Site, Washington State." In Proceedings. Fourth DOE Environmental Protection Information Meeting, pp. 489-506. CONF-821215, National Technical Information Service, Springfield, Virginia.

Abstract: The DOE's Hanford Site has been the location of nuclear activities since 1943. Site operations have produced large volumes of low-level contaminated cooling water and low-level, liquid radioactive wastes. Ground-water monitoring is necessary because some of these wastes are discharged to the ground. Two ground-water monitoring programs are currently under way. Rockwell conducts the site-specific ground-water monitoring program for the Separations Area, and PNL conducts ground-water surveillance for the entire site. These two programs are conducted separately, but activities are coordinated and data are exchanged.

Key Words: HANFORD SITE - contractor responsibilities, environmental monitoring, ground water, monitoring program

\section{W-25}

Wilde, R. T., E. A. Bracken, and E. M. Toomey. 1987. "Planning and Implementation of the Hanford Defense Waste - External Affairs Program." In Waste Management '87, Proceedings of the Symposium on Waste Management, Vol 1 General Interest, ed. R. G. Post, pp. 143-147. University of Arizona Press, Tucson, Arizona.

Abstract: In 1986, DOE-RL released a draft environmental impact statement dealing with options for the disposal of defense high-level, TRU, and tank wastes at Hanford for pubic review and comment. A public 
information and outreach program was initiated. The program's approach contained five steps: a situation analysis, development of a plan, implementation activities, a method for evaluation, and a mechanism for recommendations. To achieve a high degree of public understanding and involvement in decision making, a detailed plan was developed that outlined four major activities - conducting public meetings, establishing a citizens' forum, coordinating a speakers' bureau, and establishing a media relations program. All activities were conducted in 1986. Evaluation of public meetings indicated that the information and outreach program was a good first step. All applicable regulations were met, the DOE$R \mathbf{b}$ began to establish credibility, media treatment became less negative and more factual, and some regional consensus was reached on the need for continuing with waste disposal at Hanford using available technology.

Key Words: EFFLUENTS AND WASTES Hanford Site, information and outreach program, radioactive waste, remedial action, radioactive waste management

\section{W-26}

Wilson, R. H. 1986. "A Mobile Laboratory - Emergency Sample Analysis at the Accident Site." In Proceedings. Radiological Accidents - Perspectives and Emergency Planning, Nuclear Regulatory Commission, Washington, D.C.

Abstract: PNL, in a technical support role for the DOE, responds rapidly to the site of an accident involving radioactivity to provide an initial assessment of radiological conditions. A mobile laboratory with a trained crew can collect, prepare, and analyze samples of air, liquid, vegetation, and soil at an accident site. Rapid assessment is important because it enables immediate initiation of appropriate response and necessary long-term management of the accident site. Sensitive instruments and support equipment provide capability for emergency response in uncontrolled areas, as outlined in DOE Order 5480.1, Chapter XI. A regime is maintained to maintain proficiency and train new crew members. Response of a professional team has a positive impact on public relations, and other agencies gain confidence from the technical expertise available for assistance and backup to radiological accidents.
Key Words: HANFORD SITE - mobile laboratory samples, radiological emergency response

W-27

Wilson, R. H. 1987. Historical Review of Personal Dosimetry Development and Its Use in Radiation Protection Programs at Hanford. 1944 to the 1980's. PNL-6125, Pacific Northwest Laboratory, Richland, Washington. Irregular pages, App. A.

Contents: The development and use of personnel dosimetry at Hanford was described. Dosimeter history was divided into sections on methods of external and internal measurement, in vivo counting, records of radiation exposures, and calibration of personnel dosimeters. The reasons and circumstances surrounding the inception of these programs were discussed. Information was obtained from documents, letters, and memos available in historical records; the personnel files of many people who participated in the programs; and from the recollections of many long-time, current, and past Hanford employees. For the most part, the history of these programs was presented chronologically to relate their development and use in routine operations at Hanford.

Key Words: RADIOACTIVITY - dosimetry program (history), Hanford Site, onsite workers, radiation protection

\section{W-28}

Winters, W. I. 1981. Effect of Ph on the Destruction of Complexants with Ozone in Hanford Nuclear Waste. RHO-SA-203, Rockwell Hanford Operations, Richland, Washington, 58 p., App. A through F.

Abstract: Chemical processing of nuclear waste at Hanford has generated some waste solutions with high concentrations ( 0.1 to $0.5 \mathrm{M}$ ) of $\mathrm{N}$-(hydroxyethyl)-ethylenediaminetriacetic acid (HEDTA), ethylenediaminetetraacetic acid (EDTA), and other organic complexing agents. These complexants must be destroyed because they affect radionuclide migration in soils, waste concentration, radionuclide removal, and other waste storage processes. Previous studies on actual waste solutions demonstrated that 
preozonation of the alkaline waste significantly improved removal of radionuclides.

Bench-scale experiments with synthetic waste were performed to determine the optimum $\mathrm{pH}$ for the most efficient ozone destruction of ETDA (over the $\mathrm{pH}$ range of 1 to 14). Potential catalytic materials were examined at different $\mathrm{pH}$ levels. The EDTA-ozone reaction rates and stoichiometric requirements under varying conditions were compared.

Key Words: EFFLUENTS AND WASTES - radioactive waste, remedial studies, special treatment, waste treatment

\section{W-29}

Wolfe, B. A., P. Felise, J. L. Scott, K. R. Shah, and C. R. Allen. 1988. "Hanford Waste Vitrification Plant Project - An Overview." In Spectrum '88. Proceedings of the International Topical Meeting on Nuclear and Hazardous Waste Management, pp. 1719. American Nuclear Society, Inc., La Grange Park, Illinois.

Abstract: The Hanford Waste Vitrification Plant (HWVP) project is making full use of technology and information from other national and international vitrification activities. Following the Defense Waste Management Plan has been emphasized by focusing on the Savannah River experience. Yet the unique composition of the wastes to be vitrified at Hanford require different solutions to both technology and design problems. The HWVP can be considered a second-generation plant to both the Savannah River and West Valley plants, and lessons from these plants can be translated into HWVP improvements.

Key Words: EFFLUENTS AND WASTES - radioactive wastes, remedial studies, waste disposal, vitrification technology, waste vitrification plant

\section{W-30}

Woodward-Clyde Consultants. 1980. Assessment of the Effects of Surficial Geologic Processes in the Pasco Basin. RHO-BW-CR-129 P, Rockwell Hanford Operations, Richland, Washington. 112 p.
Abstract: A review of data regarding surficial geological processes that shaped the landscape of the Pasco Basin during Quaternary time was used to estimate the rates and net effect of similar processes for the next million years. Landscape changes in the Pasco Basin during the past million years was dominated by degradational processes. During catastrophic floods, rates of both aggradation and erosion were briefly accelerated. However, longterm rates of denudation and aggradation have been relatively low. These rates probably reflected the dry climate and, perhaps more importantly, relatively low rates of uplift and subsidence. The net effect of surficial geological processes during the next million years probably will not be significantly different. Data, particularly on rates of uplift and subsidence, were insufficient to accurately predict where the land surface will be in one million years. However, based on long-term rates of uplift, denudation, and channel incision, it was unlikely that more than $100 \mathrm{~m}$ of downcutting will occur anywhere in the Pasco Basin over this time. Rates of tectonic processes were the dominant factor affecting the evolution of the landscape in the Pasco Basin. More data are needed on the distribution and ages of Quaternary deposits to accurately assess tectonic rates during the past million years.

Key Words: GEOLOGY AND HYDROLOGY long-range surface change, Pasco Basin, surface features

\section{$\mathrm{Y}-1$}

Yandon, K. E., J. S. Burlison, and R. G. Rau. 1980. Supplemental Report on Population Estimates for Hanford Defense Waste Draft Environmental Impact Statement. PNL-3507, Pacific Northwest Laboratory, Richland, Washington. $29 \mathrm{p}$.

Contents: Population data are provided to support the ongoing evaluation of waste management programs on the Hanford Site. Population growth is predicted within a 50-mile radius of the $100 \mathrm{~N}$ Area, and within a 50-mile radius of the 300 Area. The data will be used to calculate dose to the population from waste management operations for up to 10,000 years after 1990.

Key Words: SOCIOECONOMICS - population forecast, $80-\mathrm{km}$ radius 
Z-1

Zimmerman, D. A., A. E. Reisenauer, G. D. Black, and M. A. Young. 1986. Hanford Site Water Table Changes 1950 Through 1980 - Data Observations and Evaluation. PNL-5506, Prepared for Rockwell Hanford Operations by Pacific Northwest Laboratory, Richland, Washington. $61 \mathrm{p}$.

Abstract: The magnitude and direction of changes in elevation of the water table beneath the Hanford Site from 1950 to 1980 were examined. Changes over 5year periods were plotted and related to liquid discharges from fuel reprocessing facilities or other onsite discharges. Quantitative predictions are possible of effects of future wastewater disposal practices on the water table. The plots showed a large increase in water level (ground-water mounding) near the Separations Area (200 East and 200 West) from 1950 to 1960 . The increase slowed from 1960 to 1970, while the area of mounding continued to expand. Only small changes in water level occurred from 1970 to 1980 , and the unconfined aquifer appeared to be about in equilibrium with charging sources. An increase in ground-water mounding will likely appear near B Pond in the 200 East Area as a result of increased discharges from restart of PUREX in 1983.

Key Words: GEOLOGY AND HYDROLOGY ground-water mounds, unconfined aquifer, waterlevel changes, 200 Areas 


\section{AUTHOR INDEX}

Aaberg, R. L.

Abel, K. H.

Abernethy, C. S.

Adams, M. R.

Airhart, S. P.

Albaugh, J. F.

Aldrich, J. M.

Aldrich, R. C.

Allen, C. R.

Allen, J. R.

Allen, R. M.

Allen, R. P.

Allison, J. M.

Allwine, K. J.

Ames, L. L.

Ammerman, J. J.

Andrews, G. L.

Anderson, J. D.

Anthony, R. G.

Argo, R. S.

Arnett, R. C.

Athey, G. F.

Baca, R. G.

Backman, G. E.

Badden, J. L.

Ball, I. E., Jr.

Barnes, J. R.

Barney, G. S.

Bates, D. J.

Baumbartel, R. G.

Beak Consultants, Inc.

Bean, R. M.

Beary, M. M.

Becker, C. D.

Beedlow, P. A.

Belzer, D. B.

Benson, G. L.

Berger, D. N.

Bergman, T. B.

Bierschenk, W. H.

Bihl, D. E.

Bisping, L. E.

Black, G. D.

Blair, S. C.
A-1, S-3

F-27, F-28, R-31

$\mathrm{N}-8, \mathrm{~N}-12, \mathrm{~N}-13, \mathrm{~N}-14$

A-2, A-3, M-34, P-18

S-12

A-4

F-17

A-5, A-6, A-7, A-8, A-9, A-10, A-11, A-12, A-13, A-14, B-10, B-15, H-8, T-2

W-29

$M-1$

L-9

A-15

A-16

A-28

A-17, A-18, A-19, A-20, P-17, S-1

S-11

A-21, A-22, A-23, A-24, A-25, A-26, B-17, B-18, B-19

A-4

E-4

$\mathrm{M}-22, \mathrm{M}-30$

A-27

A-28, R-3

A-27, Q-1

B-1

G-6

E-3

B-2

B-3, B-4, B-5, D-12, D-13, R-48, R-49, R-50, R-51

S-3

$S-13$

B-6

R-29, R-30

S-7

B-7, B-8, B-9, M-32, M-33, N-8, W-10

C-1, R-40

S-9, S-10

$W-2$

$S-13$

A-16

E-10

B-10, S-43

J-6

Z-1

B-11, W-2

Index-1 


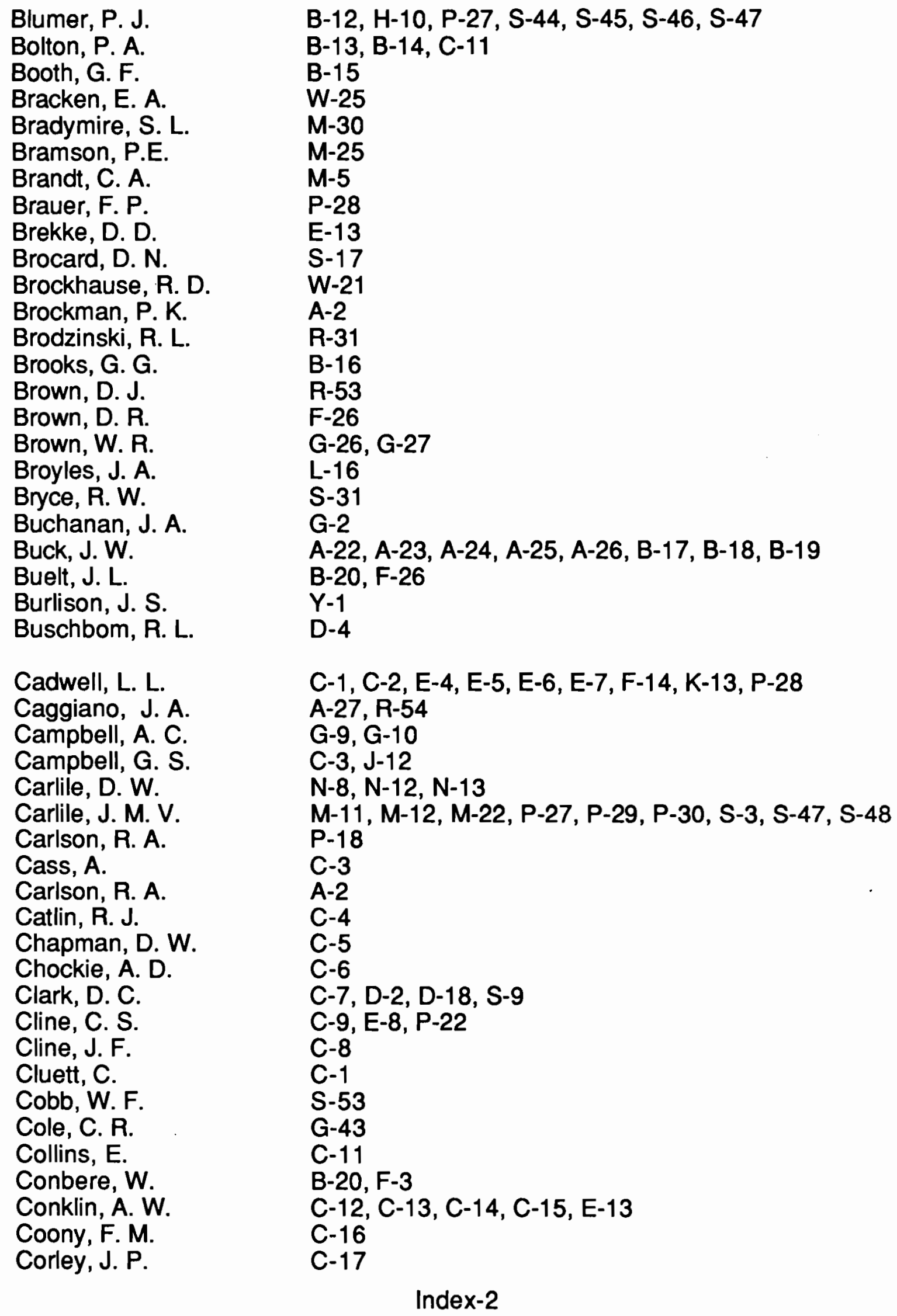

Cadwell, L. L.

Caggiano, J. A. Campbell, A. C.

Campbell, G. S.

Carlile, D. W.

Carlile, J. M. V.

Carlson, R. A.

Cass, A.

Carlson, R. A.

Catlin, R. J.

Chapman, D. W.

Chockie, A. D.

Clark, D. C.

Cline, C. S.

Cline, J. F.

Cluett, C.

Cobb, W. F.

Cole, C. R.

Collins, E.

Conbere, W. Conklin, A. W. Coony, F. M. Corley, J. P.

B-12, H-10, P-27, S-44, S-45, S-46, S-47

B-13, B-14, C-11

B-15

W-25

$M-30$

$M-25$

M-5

P-28

E-13

S-17

W-21

A-2

R-31

B-16

R-53

F-26

G-26, G-27

L-16

S-31

G-2

A-22, A-23, A-24, A-25, A-26, B-17, B-18, B-19

B-20, F-26

$Y-1$

D-4

C-1, C-2, E-4, E-5, E-6, E-7, F-14, K-13, P-28

A-27, R-54

G-9, G-10

C-3, J-12

$\mathrm{N}-8, \mathrm{~N}-12, \mathrm{~N}-13$

$M-11, M-12, M-22, P-27, P-29, P-30, S-3$, S-47, S-48

$\mathrm{P}-18$

C-3

A-2

C-4

C-5

C-6

C-7, D-2, D-18, S-9

C-9, E-8, P-22

C-8

C-1

S-53

G-43

C-11

B-20, F-3

C-12, C-13, C-14, C-15, E-13

C-16

C-17

Index-2 
Coutant, C. C.

Cowan, C. E.

Cox, G. R.

Cramer, K. H.

Crass, D. W.

Cummings, F. M.

Curl, $M$.

Cushing, C. E.

Dahlke, H. J.

Daly, D. S.

Damschen, D. W.

Daniel, J. I.

Dauble, D. D.

Davis, J. D.

Dawley, E. M.

DeFigh-Price, C.

Delegard, C. $\mathrm{H}$.

Denham, D. $H$.

Dennison, D. I.

Denovan, J. T.

Diediker, L. D.

Dillon, K. L.

Dirkes, R. L.

Divine, J. R.

Dong, F. B.

Doran, J. C.

Downs, J. L.

Drewes, D. R.

Dugan, M. K.

Dunigan, P. F. X, Jr.

Early, T. O.

Eberhardt, L. E.

Eberhardt, L.L.

Ecker, R. M.

Eddy, P. A.

Egert, G. W.

Elder, R. E.

Emery, R. M.

Endres, G. W. R.

Evans, J. C.

Eyler, L. L.

Farmsworth, R. K.

Farris, W. T.

Fawcett-Long, J. A.

Fayer, M. J.
C-18

F-27, F-28

F-29

M-22, S-35

C-19

$\mathrm{F}-17, \mathrm{~F}-18$

$\mathrm{K}-11$

B-2, C-20, C-21, C-22, C-23, C-24, C-25, C-26, C-27, R-14, R-16

D-1

$\mathrm{L}-17$

W-21

D-2

D-3, D-4, D-5, D-6, D-7, D-8, D-9, D-10, F-5, G-36, N-9, P-12

$\mathrm{L}-13$

S-53

D-1, D-11

D-12, D-13, D-14, D-15, D-16, R-49, R-51

C-17

E-16

B-1, H-6

D-17

L-11

B-12, P-27, P-30, P-31, S-45, S-46, S-47, S-49

M-3

D-18

H-7

K-9

E-1

D-18

D-19

E-1

E-2, E-3, E-4, E-5, E-6, E-7, M-18, M-19

$M-18$

D-5

B-12, E-8, E-9, E-10, E-11, P-22, S-49, W-24

E-13, E-14

C-13, C-14, C-15, E-12, E-13, E-14

E-15

F-17

E-16

L-18

F-1, O-1

$\mathrm{H}-9, \mathrm{~S}-14$

$\mathrm{L}-15$

F-2, F-3, F-4 
Fecht, K. R.

Felise, P.

Fickeisen, D. H.

Filby, R. H.

Fitzner, R. E.

Fix, J. J.

Flinders, J. T.

Flyckt, D. L.

Fogel, P. A.

Foley, M. G.

Forrester, H. A.

Fox, G. R.

Freshley, M. D.

Friedli, E. A.

FritzPatrick, V. F.

Fruchter, J. S.

Fuchs, M. R.

Gallager, S. A.

Gaines, $H$.

Gaines, W. E.

Garland, T. R.

Gasper, K. A.

Gano, K. A.

Gee, G. W.

Geffen, C. A.

Gephart, R. E.

Gerboth, D. M.

Gibson, D. D.

Gibson, M. W.

Gifford, O. P.

Glantz, C. S.

Gilbert, E. S.

Gilbert, F. G.

Gilbert, R. O.

Gilbert, T. W.

Gilmore, R. D.

Givin, D. C.

Glantz, C. S.

Glennon, M. A.

Goles, G.

Graham, D. L.

Graham, M. J.

Gray, R. H.

Greager, E. M.
G-28, R-53, T-1, V-1

W-29

B-9, F-5, F-6, M-33

F-7

C-2, F-6, F-8, F-9, F-10, F-11, F-12, F-13, F-14, F-15, F-16,

M-5, P-17, R-15, R-16, R-18, R-29, R-38, W-10, W-13

F-17, F-18, F-19, M-25

$\mathrm{S}-34$

$\mathrm{M}-24$

F-20

W-10

F-21

T-2

B-21, F-22, G-43, M-31, S-3

F-23, F-24, F-25, S-37

F-26

F-27, F-28

F-29, L-11, R-52, W-14

D-13, D-14, D-15, S-7

C-11

G-1

R-17

F-21, I-1

C-8, G-2, G-3, G-4, G-5, G-6, G-7, K-13, P-32, R-39, W-10

F-3, F-4, G-8, G-9, G-10, G-11, G-12, G-13, H-5, J-12, J-13, J-14, J-15, K-9, K-10, K-11, L-6, P-17, W-3

T-3

A-27, G-14, G-15

G-16

$J-14$

G-16

S-8, S-38

R-4

G-17, G-18, G-19, G-20

P-15

P-32

$\mathrm{P}-16, \mathrm{P}-19$

G-21

$F-27, F-28$

G-22, G-23

L-6

$\mathrm{J}-11$

G-24, S-31

F-22, G-25, G-26, G-27, G-28, W-3, W-23

C-19, D-6, G-29, G-30, G-31, G-32, G-33, G-34, G-35, G-36, $\mathrm{H}-2, \mathrm{~N}-\mathrm{9}$

G-37, G-38, G-39, G-40, G-41

Index-4 
Groth, D. R.

Gurley, R. N.

Gurtisen, J. M.

Gutknecht, P. J.

Hadley, R. T.

Haggard, D. L.

Hall, M. D.

Hanf, R. W., Jr.

Hanson, E. E.

Hanson, W. C.

Hartman, D. T.

Hartley, J. N.

Hawley, K. A.

Haynes, J. M.

Hayward, W. M.

Hazelton, R. F.

Hedlund, J. D.

Heller, P. R.

Herborn, D. I.

Hicks, R. J.

Highby, D. P.

Higiey, B. A.

Higley, K. A.

Hines, W. T.

Hobbs, J. M.

Hoitink, D. J.

Holbrook, K. L.

Horst, T. W.

Hostick, C. J.

Howe, D. B.

Howes, B. W.

Huizenga, D. G.

Huston, J. R.

Imhoff, K. L.

Isaacson, R. E.

Islam, M. M.
A-4

G-42

C-25

G-43

H-1

F-18

G-27

$\mathrm{D}-8, \mathrm{~N}-10, \mathrm{~N}-11$

E-5, E-6, E-7

R-19

S-53

P-20

M-22, M-27

$\mathrm{H}-2$

H-3

A-15

$\mathrm{H}-4$

F-3, G-11, H-5

F-24

B-20

H-6

S-7

S-35

F-15

F-18

S-8, S-38

F-18, F-19

$\mathrm{H}-7$

C-6

C-16, H-8

W-2

$\mathrm{H}-9, \mathrm{~S}-14$

$\mathrm{H}-10$

W-10

F-21, I-1

G-22 
Jackson, R. L. Jacobs, G. K. Jacques, I. D. Jaquish, R. E. Jamison, J. D. Jansky, M. T. Jenkins, C. E. Jensen, E. J. Jensen, R. J. Jenne, E. A. Jette, S. J. Johnpeer, G. D. Johnson, A. R. Johnson, R. G. Johnson, V. G. Jones, T. L. Jordan, W. R. Jungfleisch, F. M.

Kaar, P. H.

Kaiser Engineers Hanford Company Kalder, R. A. Kaplan, M. F. Kasper, R. B. Kennedy, W. E., Jr. Kerns, R. E.

Kimura, R. T.

King, S. E.

Kincaid, C. T.

Kinnison, R. R.

Kirkham, R. R.

Klem, M. J.

Klepper, E. L.

Krupin, P. J.

Kuhn, W. L.

Kupfer, M. J.

Lamar, D. A.

Landeen, D. S.

Landstrom, D. K.

Larson, J.

Larvie, F. C.

LaRue, K. M.

Last, G. V.

Laul, J. C.

Law, A. G.

Law, L. S.
G-15

E-1

$J-1, J-2$

C-17, J-5, J-6, J-7, J-8, P-33

$\mathrm{J}-3$

$\mathrm{J}-4$

$M-27$

$\mathrm{J}-9, \mathrm{~J}-10$

$\mathrm{H}-3, \mathrm{P}-22$

F-27, F-28

S-35

J-11, M-35

$\mathrm{E}-14, \mathrm{~S}-54$

S-7

C-13, L-8, S-23

C-3, F-4, G-10, G-12, J-12, J-13, J-14, J-15, K-10

R-52

J-16, S-7

$\mathrm{D}-2$

$\mathrm{K}-1$

$\mathrm{K}-2$

A-3

$\mathrm{D}-15, \mathrm{~K}-3, \mathrm{~K}-4, \mathrm{~K}-5$

K-6, K-7, N-3, N-4, N-6

R-4

D-16

F-26

K-8, S-16

P-34

G-13, J-14, J-15, K-9, K-10, K-11

$\mathrm{K}-12$

$\mathrm{K}-13$

$\mathrm{M}-22$

B-20

S-7

B-20, M-22, S-35

$L-1, L-2, S-54, V-1$

$\mathrm{M}-36, \mathrm{~W}-2$

L-3

$L-4$

G-42

G-28, L-5, L-6, L-7, T-1, V-1

L-8, S-23

C-13, D-16, L-9, L-10, L-11, L-12, S-11, W-22

B-11

Index-6 
Leaming, G. F.

Leder, J. E.

Ledgerwood, R. D.

Ledgerwood, R. K.

LeGore, V. L.

Leonhard, L.A.

Leopoid, E. B.

Lie, W.

Liebetrau, S. F.

Liebow, E. B.

Liikala, T. L.

Lindberg, J. W.

Logan, S. E.

Lokken, R. O.

Lombardo, N. J.

Lu, A. H.

Lusty, E. W.

Lutrell, S. P.

Maas, L. J.

Mackey, D. B.

Makhijani, A.

Malhotra, S.

Marr, N. V.

Marratt, M. C.

Martin, W. J.

McArthur, J. V.

Mcbeth, P. J.

McCallum, R. G.

McCormack, W. D.

McCorquodale, S. M.

McDaniel, E. W.

McGarrah, J. E.

McGhan, V. L.

McLane, M. T.

McLaughlin, T. J.

McLaurine, S. B.

McMakin, A. H.

McNamee, P. C.

McShane, M. C.

McStay, J. R.

Meinhardt, C. C.

Merrill, E. H.

Michels, D. E.

Miller, D.

Miller, M. L.

Miller, R. A.

Miller, R. L.
$\mathrm{L}-13$

S-2

S-53

D-17

S-12

S-4

L-14

D-19

R-22

L-15, L-16, N-7

L-7, L-17, P-22, S-3

B-11

A-2

T-3

L-18

F-21, R-41, S-18, W-23

$\mathrm{N}-8$

S-54, W-14

$M-6, M-7, M-8, M-9, M-10$

$M-3$

$\mathrm{M}-4$

C-10

$\mathrm{M}-5, \mathrm{P}-21$

$\mathrm{T}-1$

O-2

B-2

$\mathrm{M}-1, \mathrm{M}-2$

$W-10$

$M-11, M-12, M-13, S-26, S-48, S-49$

$M-14, M-15, M-16, M-17, M-18, M-19, M-20, P-21, R-1$

$\mathrm{K}-2$

A-18, A-19, A-20, S-1

$M-21$

$\mathrm{N}-12$

M-22, S-35

$\mathrm{S}-12$

H-9, S-14

Q-1

E-15, M-23, R-19, R-20

C-10

M-23, P-16

R-1

C-17

J-11

M-25

F-12

M-26 
Minor, J. E.

Mishima, J.

Mitchell, D. E.

Mitchell, P. J.

Mitchell, R. M.

Montgomery, J. C.

Moore, B. A.

Morgan, L. G.

Murphy, P. J.

Murthy, K. S.

Myers, C. W.

Myers, D. A.

Nakaota, R. A.

Napier, B. A.

Nealy, S. M.

Neitzel, D. A.

Nelson, C. L.

Nelson, D. M.

Nelson, J. L.

Nesse, R. J.

Neuder, S. M.

Newbill, C. A.

Newell, R. L.

Newland, G. J.

Nisick, N. P.

Norman, W. T.

Olsen, A. R.

Olsen, K. B.

Oma, K. H.

Opitz, B.E.

Osborne, W. L.

Oster, K. R.

Owens, K. W.

Pacific Northwest Laboratory

Page, T. L.

Paine, D.

Palmer, R. A.

Pavlina, R. S.

Peloquin, R. A.

Perez, J. M.

Perkins, C. J.
G-42

$M-27$

$M-28$

E-16, J-7, K-8, M-21, M-29, M-30, M-31, S-3

$L-1, L-2, P-18, S-54, V-1$

B-9, M-32, M-33

S-39

M-34

M-35

$M-36$

G-15, M-37

H-5, W-10

P.12

A-1, F-26, J-8, K-6, K-7, M-12, M-13, M-27, M-36, N-1, N-2, $\mathrm{N}-3, \mathrm{~N}-4, \mathrm{~N}-5, \mathrm{~N}-6$

$\mathrm{N}-7$

D-5, D-10, F-5, G-36, N-8, N-9, N-10, N-11, N-12, N-13, N-14, P-10, R-29, R-30

$0-2$

$\mathrm{K}-11$

$\mathrm{N}-15$

S-9

$\mathrm{N}-4$

M-30

D-9

S-8

B-1

S-53

C-17

S-3

F-26, O-1

$\mathrm{O}-2$

C-13, C-14, C-15, E-13, E-14

P-22

M-34

P-1, P-2, P-3, P-4, P-5, P-6, P-7, P-8, P-9

D-6, D-7, D-8, G-36, N-9, N-10, N-11, N-12, N-13, N-14, P-10, W-10

R-54

S-7

P-13

$\mathrm{M}-12, \mathrm{~N}-4, \mathrm{~N}-5$

$\mathrm{P}-12$

$P-13$

Index-8 
Perrault, P. J.

Peters, B. B.

Petersen, G. R.

Peterson, M. E.

Petron, S. E.

Phillips, S. J.

Piatt, J. A.

Pierce, C. A

Pisarcik, J. M.

Poole, L. D.

Poremba, B. E.

Poston, T. M.

Prater, L. S.

Preston, E. R.

Price, K. R.

Price, S. M.

Price, W. H.

Prohammer, L. A.

Quinn, D. J.

Rader, R. T.

Raedeke, K. J.

Ramsdell, J. V.

Rasmussen, J. H.

Rasmussen, O. R.

Rau, R. G.

Raymond, J. R.

Raymond Kaizer Engineers

Reinecke, G. N.

Reisenauer, A. E.

Rice, D. G.

Rice, W. A.

Richardson, G. L.

Richmond, W. G.

Rickard, W. H.

Rieger, J. T.

Riley, R. G.

Robertson, D. E.

Robertson, P. L.

Robinson, D. C.

Robkin, M. A.

Rockwell Hanford Operations
S-8

G-16

G-19, G-20

F-1

M-19, P-14, P-15

F-21, P-16, P-17, P-18, P-19, P-20

B-1

$\mathrm{F}-12$

C-15

$M-5, P-21$

T-2

$\mathrm{D}-9, \mathrm{~N}-12, \mathrm{~N}-13, \mathrm{~N}-14$

E-8, E-9, P-22, W-24

S-8

P-23, P-24, P-25, P-26, P-27, P-28, P-29, P-30, P-31, P-32,

P-33, P-34, S-26, S-48, S-49, S-50, T-4, W-10

A-27, G-14, G-15, M-37

R-53

R-30

Q-1

$\mathrm{C}-22$

$\mathrm{M}-20, \mathrm{R}-1$

A-28, G-23, M-13, R-2, R-3, R-4, W-10

$P-11$

R-5

$\mathrm{S}-27, \mathrm{Y}-1$

C-9, E-10

R-6

S-8

$M-36, S-16, W-2, Y-1$

R-7, W-10

G-43

R-8

R-9

C-23, D-19, F-5, F-13, F-14, F-15, G-4, P-17, R-10, R-11, R-12, R-13, R-14, R-15, R-16, R-17, R-18, R-19, R-20, R-21, R-22, R-23, R-24, R-25, R-26, R-27, R-28, R-29, S-6, C-9, P-22, E-9, S-3

R-29, R-30

F-27, F-28, R-31

$\mathrm{F}-18$

$\mathrm{S}-27$

W-2

R-32, R-33, R-34, R-35, R-36, R-37 
Rogers, L. E.

Rokkan, D. J. Roos, R. C. Roswell, R. L. Routson, R. C.

Rowe, S. E.

Sargeant, G. A.

Salter, P. F.

Sandness, G. A.

Sauer, R. H.

Schadt, T. H.

Schalla, R.

Schatz, A. L.

Schreckhise, R. G.

Schreiber, D. L.

Schuler, C. A.

Schultz, R. W.

Schultz, W. W.

Schwab, G.

Schwartz, M. N.

Scott, A. J.

Scott, J. L.

Scott, M. J.

Serkowski, J. A.

Serne, R. J.

Sevigny, G. J.

Sewart, G. H.

Shah, K. R.

Shay, R. S.

Sheldon, J. K.

Sherwood, D. R.

Siemens, D. H.

Silviera, D. J.

Simmons, C. S.

Singarella, P. N.

Sipco, E. T.

Sission, J. B.

Skaggs, R. L.

Skalski, J. R.

Skumatz, L. A.

Sliger, G. J.

Slingby, J. A.

Smith, K. A.

Smith, M. J.

Smith, M. R.
C-8, F-14, G-5, G-6, H-4, R-21, R-22, R-38, R-39, R-40, R-41, S- 15

R-42, R-43, R-44, R-45, R-46

S-54

N-6

D-16, F-21, R-47, R-48, R-49, R-50, R-51, R-52, R-53,

R-54, V-1

$\mathrm{F}-12$

S-6

A-19, A-20, S-1

$\mathrm{P}-17$

F-6, M-23, R-23, R-24, S-2

C-5

S-3, S-4, S-5

L-10, L-11, L-12, S-11

F-16, P-28

W-10

R-25, S-6

S-9

F-21, M-34, S-7

S-51

S-8

C-25

W-29

S-9, S-10

L-12, S-11

B-20, S-12

$\mathrm{S}-13$

S-14

G-42, S-13, W-29

B-15, H-8

R-40, S-15

$M-22,0-2$, S-35

G-42, S-13

F-26

$\mathrm{P}-17, \mathrm{~S}-16$

S-17

F-16

R-54, S-18

F-5, S-19, S-25

G-6

W-10

A-12, S-20, S-21

C- 10

$\mathrm{M}-2$

S-22

L-8, S-23 
Smith, R. M.

Smoot, J. L.

Sneider, S. C.

Soldat, K. L.

Sommer, D. J.

Somers, S. R.

Spane, F. A., Jr.

Springer, J. T.

Squires, D. J.

Stanfield, L. J.

States, J. B.

Steigers, W. D., Jr.

Stein, S. L.

Stenner, R. D.

Stickney, R. G.

Stohr, J. S.

Stone, R.

Stone, W. A.

Stokowski, P. A.

Stout, L. A.

Strait, S. R.

Streille, G. P.

Strenge, D. L.

Strickler, J. J.

Sula, M. J.

Summers, W. K.

Sutter, S.L.

Swan, G.A.

Swanson, J. L.

Swanson, L. C.

Tabor, R. D.

Tallman, A. M.

Tanner, T. M.

Tawil, J. J.

Taylor, C. D.

Teel, S. S.

Terrill, E. S.

Thomas, J. M.

Thompson, R. L.

Thorp, J. M.

Thorson, M. R.

Timmerman, C. L.

Tomlinson, K. M.

Toomey, E. M.

Toste, A. P.

Treat, R. L.
R-48, R-49, R-50, R-51, S-24, V-2

B-20

S-25

$\mathrm{F}-17, \mathrm{~N}-3, \mathrm{~S}-26$

S-27, W-10

S-28, S-29, S-30

S-31, S-40

S-32

S-33

A-13, A-14, B-10, B-15

G-7

S-34

T-3

S-35

S-36

F-7

R-41

$\mathrm{S}-38$

S-9, S-3

$M-36$

G-27, S-39, S-40

$\mathrm{S}-14$

$\mathrm{N}-5, \mathrm{~N}-6$

$\mathrm{S}-41$

B-12, S-42, S-43, S-44, S-45, S-46, S-47, S-48,

S- 49, S-50

S-51

$M-27$, S-52

S-53

$\mathrm{J}-15$

S-54

$\mathrm{M}-20$

$\mathrm{T}-1$

$\mathrm{T}-2$

W-10

F-24

E-10

L-15

C-24, R-30

G-42

S-38

$\mathrm{F}-18$

F-26, O-1

F-24

W-25

F-27, F-28, L-17, R-31

H-9, K-2, S-12, S-14, T-3 
Trevathan, M. S.

Tucker, K. M.

UNC Nuclear Industries, Inc.

Uresk, D. W.

Uresk, V. A.

URS/John A. Blume and Associates,

Engineers

U.S. Department of Energy

U.S. General Accounting Office

U.S. Geological Survey

U.S. Geological Survey and Performance

Assessment Group (RHO)

Vail, L. W.

Van Houten, N. C.

Van Luik, A. E.

Vaughan, B. E.

Veatch, M. D.

Voight, L. J.

Wagner, R. N.

Wahlen, R. K.

Walker, B. A.

Walker, D. E., Jr.

Wallace, R. W.

Wallskog, H. A.

Walter, M. B.

Walters, W. H.

Warren, J. L.

Washington Public Power Supply System

Waters, E. D.

Watrous, R. A.

Watson, D. G.

Watson, E. C.

Waugh, W. J.

Weber, H. W.

Weekes, D. C.

Weiss, R. L.

Weitkamp, D. E.

Welch, J. R.
P-27, P-30, T-4

$M-4$

$\mathrm{U}-1$

$\mathrm{U}-2$

$\mathrm{U}-2$

$\mathrm{U}-3$

U-4, U-5, U-6, U-7, U-8, U-9, U-10, U-11, U-12, U-13, U-14, U-15, U-16, U-17, U-18, U-19, U-20, U-21, U-22, U-23, U-24, U-25, U-26, U-26, U-27

$\mathrm{U}-28$

$\mathrm{U}-29$

$\mathrm{U}-30$
D-5, D-10

S-35

$\mathrm{V}-1, \mathrm{~V}-2$

$\mathrm{R}-22$

$\mathrm{V}-3$

C-16, $\mathrm{H}-8$

F-1

$M-26$

A-19, A-20

W-1

W-2, W-10

S-41

W-3

S-19, W-2

F-5, F-6, R-26, R-27

W-4, W-5, W-6, W-7, W-8

W-9

S-7

C-23, C-25, R-28, W-10

W-10

P-16, W-11, W-12

$W-13$

S-54, W-14

D-16, W-15

C-6

S-41

Index-12 
Welsh, T. L.

Westinghouse

Hanford Company

Wheeler, R. E.

Whelan, $G$

White, D. A.

White, D. E.

Wierenga, P. J.

Wilbur, J. S.

Wilde, R. T.

Wilson, R. H.

Winter, C.

Winters, W. I.

Winterhalder, J. A.

Wirsing, R. M.

Wolf, E. G.

Wolf, G. A.

Wolfe, B. A.

Wood, B. J.

Wood, D. E.

Woodley, N. E.

Woodward-Clyde

Consultants

Yandon, K. E.

Yost, P. R.

Young, M. A.

Younger, C. A.

Zimmerman, D. A.

Zimmerman, M. G.

Zweifel, D. N.
C-5

W-16, W-17, W-18, W-19, W-20

W-22

$W-21$

C-17

M-4

G-10

E-11, W-23, W-24

$W-25$

W-26, W-27

C-6

W-28

$M-24$

$\mathrm{M}-24$

C-26, C-27

S-7

W-29

B-5

Q-1

R-40

W-30

$\mathrm{Y}-1$

F-25

$\mathrm{L}-6, \mathrm{Z}-1$

L-16

$\mathrm{Z}-2$

W-2

T-2 


\section{KEY WORD INDEX}

\section{AIR AND ATMOSPHERE}

$\begin{array}{ll}\text { Climatological/Meteorological } & \text { Data } \\ \text { abnormal conditions } & \mathrm{S}-8 \\ \text { air quality } & \mathrm{G}-223 \\ \text { atmospheric dispersion } & \mathrm{A}-28, \mathrm{R}-3, \mathrm{R}-4 \\ \text { climate } & \mathrm{L}-14 \\ \text { data collection/processing } & \mathrm{A}-21, \mathrm{G}-22, \mathrm{R}-4 \\ \text { Hanford Reach } & \mathrm{A}-25 \\ \text { Hanford Site } & \mathrm{A}-21, \mathrm{C}-21, \mathrm{~L}-14, \mathrm{~S}-38 \\ \text { impact assessment } & \mathrm{G}-23 \\ \text { historical review } & \mathrm{L}-14, \mathrm{~S}-38 \\ \text { information needs } & \mathrm{L}-14 \\ \text { monitoring programs } & \mathrm{G}-22 \\ \text { monitoring sites } & \mathrm{G}-22 \\ \text { nocturnal slope flow } & \mathrm{H}-7 \\ \text { precipitation } & \mathrm{L}-14 \\ \text { Rattlesnake Mt. } & \mathrm{H}-7 \\ \text { short-term effects } & \mathrm{S}-8 \\ \text { snowfall } & \mathrm{S}-8 \\ \text { temperature } & \mathrm{H}-7, \mathrm{~S}-8 \\ \text { tracer studies } & \mathrm{R}-4 \\ \text { weather conditions } & \mathrm{S}-38 \\ \text { wind } & \mathrm{H}-7\end{array}$

\section{Computer Models/Codes}

CHISHORT model

(simple atmospheric dispersion)

GEN code

\section{B-17 \\ G-23}

(simple atmospheric dispersion)

LOGRVU model

MESOI model (diffusion)

PROD model

A-28

A-28, R-3

REVIEW model

A-22

A-26

RIVER model (river flow)

A-25

TANK code (tank farm winds)

TOWER code (wind tower data)

B-18

B-19

UPDATE model

A-28

SFC model

A-24

SUM model

A-23

\section{Hanford Meteorological Station}

A-21, A-22, A-23, A-24, A-25, A-26, G-12

computer program

A-22, A-23, A-24, A-25, A-26, A-28

B-17, B-18, B-19, R-3

Index-15 
archives (records)

data base

equipment/facilities

Emergency Management

System (EMS)

weather observations

weather forecasts

wind forecasts

wind speed and direction
A-21, B-17, B-18, B-19

A-21

A-21, G-22

A-26

A-22, A-23, A-24, A-26, B-19

B-17

B-18

A-22 


\section{AQUATIC ECOLOGY}

Aquatic Insects

C-18, D-6, G-1, P-10

caddis fly adults

mayfly nymphs

C-18

C-22

\section{Animal Documentation}

$\begin{array}{ll}\text { aquatic insects } & \text { P-10 } \\ \text { aquatic organisms } & \text { B-6 } \\ \text { aquatic plants } & \text { C-24 } \\ \text { benthic organisms } & \text { B-6, B-9, D-6, P-10 } \\ \text { cladocera } & \text { D-6 } \\ \text { fish parasites } & \text { B-7 } \\ \text { periphyton } & \text { C-27, N-10 } \\ \text { phytoplankton } & \text { B-6, N-10 } \\ \text { watercress } & \mathrm{C}-27 \\ \text { zooplankton } & \text { B-6, D-6, N-11 }\end{array}$

Anadromous Fish

B-6, B-7, B-8, B-9, F-5, S-53

Chinook salmon -

Oncorhynchus tschawytscha juvenile Chinook salmon juvenile salmonids salmonids

B-8, C-5, N-8, S-53

D-6, D-8, G-36

D-7

G-29

\section{Community Characteristics}

abundance

allochthonus detritus

community production

community structure

ecological relations

endangered/threatened

species

insect production

leaf decomposition

organic energy budget

primary production

relative abundance

respiration

secondary production

species composition

Impact Assessment (effect of)

air supersaturation

assessment (general)

cooling water discharge

B-8

B-2, C-20

E-15

B-6, E-15

B-2, C-20, C-25

F-6

G-1

B-2, C-22

C-26

C-20, C-26, C-27, N-10

$\mathrm{N}-11$

$\mathrm{C}-27$

C-22, G-1

$\mathrm{N}-10, \mathrm{~N}-11$

$\mathrm{M}-32$

C-5, G-29, G-30

C-25

Index-17 


$\begin{array}{ll}\text { dam construction } & \text { F-5, F-6 } \\ \text { entrainment } & \text { G-36 } \\ \text { Hanford operations } & \text { B-8 } \\ \text { power generation } & \text { G-29, G-36 } \\ \text { radioactivity } & \mathrm{C}-25, \mathrm{E}-16 \\ \text { reactor shutdown } & \mathrm{C}-25 \\ \text { redd dewatering } & \mathrm{N}-8 \\ \text { trace metals } & \mathrm{C}-24 \\ \text { water-level fluctuations } & \mathrm{B}-9, \mathrm{C}-5, \mathrm{M}-33\end{array}$

\section{Project Assessment}

Ben Franklin Dam F-5, F-6 (proposed)

HGP (Hanford Generating G-36 Project)

WNP-2 (Washington Nuclear Project No.2)

Life History/Characteristics of Fish

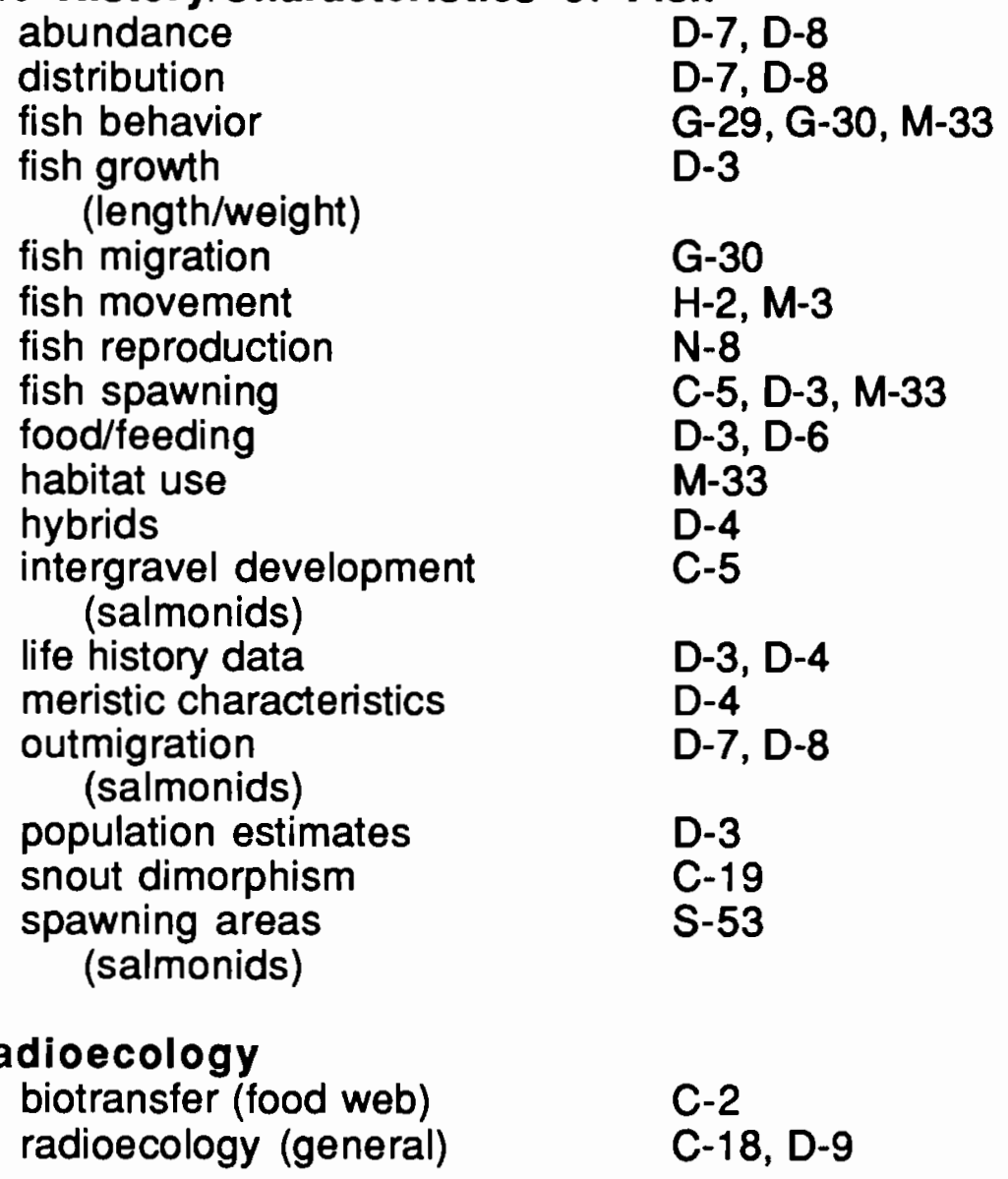




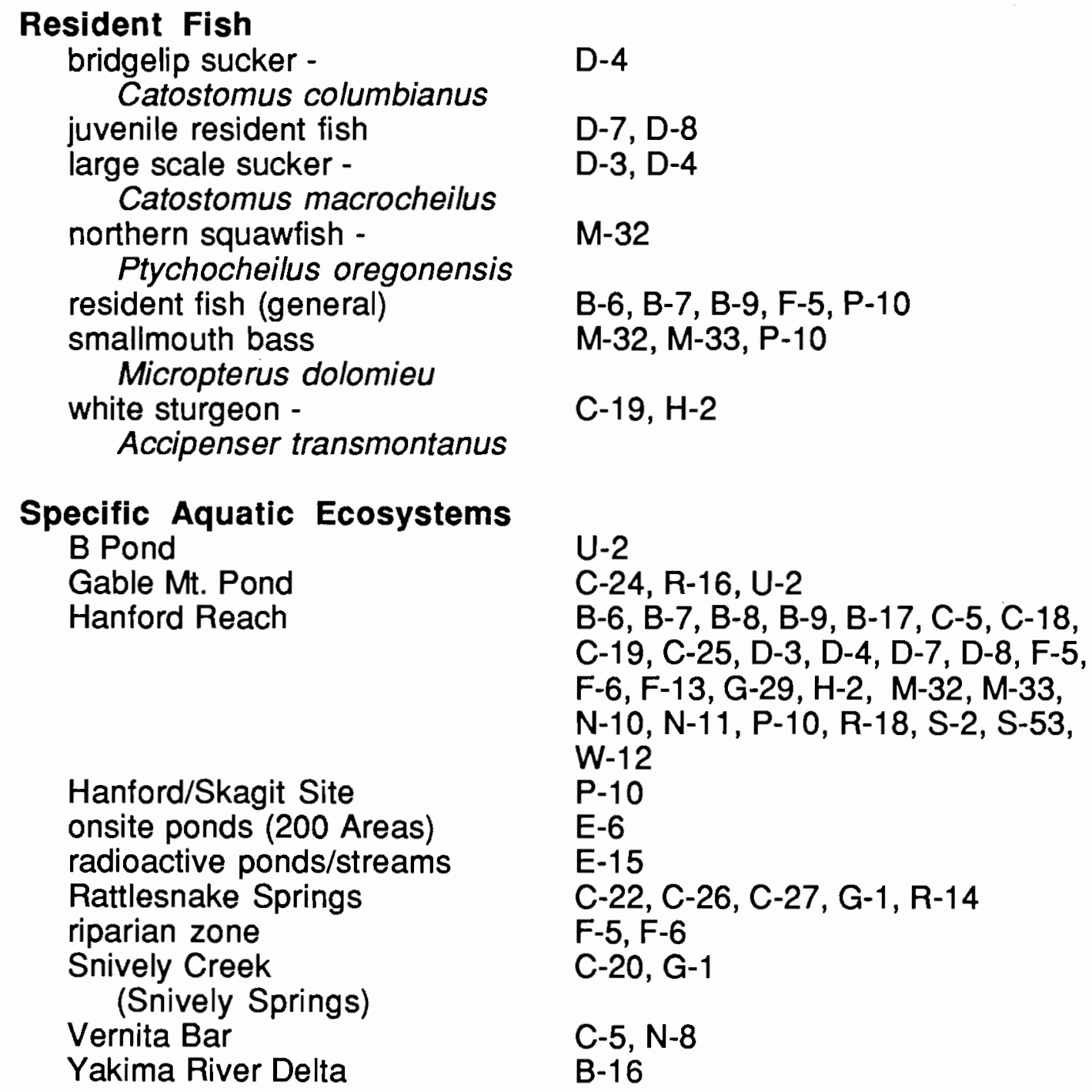




\section{EFFLUENTS AND WASTES}

\section{Computer Models/Codes}

COMPACT model (Computer

Optimization of Processing

and Cash Transport)

computer simulation

Dry Well Radioactive

C-6

Response Equation

(DWRRE)

TRANSS (groundwater transport of radionuclides)

UNSAT-H (unsaturated flow, $H$ version)

UNSAT-2 (unsaturated flow, two dimensional)

Effluents and Emissions (description) J-16, R-42, R-43, R-44, R-45, R-46

airborne emissions gaseous emissions

C-13, C-14, C-15, C-16, R-2

liquid effluents

F-3

F-21, I-1

S-16

F-2, F-4, G-8

F-2

A-7, A-12, A-13, A-14, B-15, T-2

A-5, A-6, A-8, A-9, A-11, B-15, B-20, C-16, J-16, O-2, T-2, W-15, W-17

radioactive liquids

sanitary effluents

solid wastes

waste generation

D-2, D-16, G-16, J-16, S-20, S-21, W-17

C-16

H-8

$\mathrm{J}-16, \mathrm{M}-1, \mathrm{M}-2, \mathrm{~T}-2$

\section{Environmental Assessment/Monitoring}

A-5, A-6, A-7, A-8, A-9, A-10, A-11, A-12, A-13, A-14, B-10, B-15, C-4,

C-13, C-14, C-15, C-16, G-26, H-8, H-9, P-2, P-5, P-6, P-7, P-13, R-42,

R-44, R-45, R-46, S-5, S-20, S-21, S-54, T-2, U-19, V-1, V-2, W-20

biological intrusion

biomonitoring

biotransport

geohydrologic issues

ground water

ground-water mounds

ground-water transport

monitoring program

monitoring wells

radioactive waste storage
C-12, L-1, L-2

C-12

C-13, C-14, C-15, L-2

$\mathrm{V}-1$

A-9, A-10, H-11, D-16, G-25, G-26, P-2, P-5, P-6, P-7, P-13, S-3, S-5,

$\mathrm{U}-19$

$\mathrm{J}-10$

S-16

G-25, P-11, S-3

G-26

D-1, D-2, D-11, I-1 
radioactivity

(also see RADIOACTIVITY)

stratiography

surface soil

surface soil/vegetation

waste storage tanks

single-shell tanks

tank integrity

tank surveillance

tank leak detection
A-6, A-7, A-9, A-10, A-11, A-12,

A-13, A-14, B-15, C-13, C-14, C-15, C-16, G-26, H-8, R-42, R-43, R-44, R-45, S-5, S-20, S-21, S-54, T-2, U-19, V-2

S-3

$\mathrm{N}-1$

$\mathrm{J}-5, \mathrm{P}-13$

D-11, I-1, J-4

D-1, F-21,

D-1, D-2, D-11, Q-1, R-47

C-4, I-1

F-21

Hazardous Materials (nonradioactive)

A-5, A-8, A-12, A-13, A-14, B-1, B-10, B-20, C-16, J-16, K-12, $M-22, M-25, P-2, P-5, P-6, P-7$ ammonium hydroxide carbon tetrachloride

B-20, W-20

chlorinated hydrocarbons

E-16

cyanide

E-16

E-16

gaseous effluents (NOx, SOx) heavy metals

P-11

hexavalent chromium

A-5, A-8

nitrate

E-16

B-20, E-16

oxides of nitrogen (NOx)

R-2

\section{Radioactive Materials}

A-2, A-3, A-15, A-16, P-2, P-5, P-6, P-7

buried waste

P-18, P-20, W-11, W-12

high-level waste (HLW)

C-4, D-1, D-2, D-11, F-1, G-16

G-42, H-3, I-1, J-4, M-27, M-34, M-36,

N-15, O-1, P-13, R-5, R-32, R-33, R-34,

low-level waste (LLW)

R-37, S-41, W-2

radioactive liquids

A-16, H-9, M-1, M-2, R-38

D-2, D-16, J-10, J-16, K-12, M-2,

radioactive sludge

R-57, S-20, S-21, S-24, W-9, W-17

J-4, R-5

radioactive solid waste

$M-26, M-28, S-36$

radioactive waste

C-4, C-8, C-11, C-12, F-26, K-3

K-4, K-5, L-1, L-2, L-5,

$\mathrm{M}-3, \mathrm{M}-22, \mathrm{M}-24, \mathrm{P}-12, \mathrm{P}-13, \mathrm{P}-17$,

P-20, Q-1, S-3, S-12, S-13,

S-14, S-22, T-2, U-24, V-1, W-11,

W-12, W-25, W-28, W-29

radionuclide inventory

$M-26$ 
transuranic (TRU) waste

waste characterization
A-4, A-15, G-42, K-3, K-4, K-5, R-34, R-35, R-39

$\mathrm{K}-12, \mathrm{M}-1, \mathrm{M}-2, \mathrm{M}-34, \mathrm{D}-35$

\section{Radionuclides (also see RADIOACTIVITY)}

K-6, O-1, R-42, R-43, R-44, R-45, R-46, R-53, S-16

americium

cesium

plutonium

strontium

tritium

uranium
$\mathrm{K}-3, \mathrm{~K}-5, \mathrm{~L}-5$

$\mathrm{L}-2, \mathrm{~L}-5, \mathrm{D}-24, \mathrm{~V}-2$

$\mathrm{K}-3, \mathrm{~K}-4, \mathrm{~K}-5, \mathrm{~L}-5, \mathrm{~S}-24$

S-24, V-2, W-15

W-9

D-16

Site-Specific Effluents

B-Plant

Hanford Site (general)

G-16

A-15, C-4, D-16, G-25, J-16, M-22,

M-24, N-2, P-1, P-12, P-16, P-18,

P-19, P-20, R-9, R-34, R-35, R-36,

R-37, S-22, S-36, S-41, W-17, W-25

N Reactor

PUREX Plant

WNP-2

$\mathrm{UO}_{3}$ Plant

P-15, R-42, R-43, R-44, R-45, R-46,

S-14

A-5, A-6, A-7, A-8, A-9, A-10, A-11, A-12, A-13, A-14, B-10, B-15, G-16, H-8, P-11, R-2, W-9

$M-1, M-2$

A-5, A-6, A-8, B-10, B-15, H-8, P-11

100 Areas

B-20, C-1, O-2, P-13, R-42, R-43, R-44,

$\mathrm{R}-45, \mathrm{R}-46$

$100 \mathrm{~N}$ shoreline springs

200 Areas (Separation

Areas)

300 Area

400 Area

P-13, R-42, R-43, R-44, R-45, R-46,

$\mathrm{R}-47, \mathrm{R}-48$

A-2, A-5, A-6, A-7, A-8, A-9, A-10, A-11, A-12, A-13, A-14, B-10, B-15, C-4, C-13, C-14, C-15, F-21, G-26, H-8, I-1, J-4, K-3, K-4, K-5, K-12, L-5, M-34, M-36, P-11, Q-1, R-2, R-5, R-32, R-33, R-47,

$\mathrm{R}-53, \mathrm{~S}-14, \mathrm{~S}-20, \mathrm{~S}-21, \mathrm{~S}-24, \mathrm{~S}-41, \mathrm{~T}-2$,

$\mathrm{V}-1, \mathrm{~V}-2, \mathrm{~W}-20$

P-17, S-3, S-5

$M-1, M-2$

\section{Waste Disposal/Treatment}

A-2, A-4, A-5, A-6, A-7, A-8, A-9, A-10, A-11, A-16, B-20,

C-1, C-6, C-8, C-11, C-16, C-17, D-16, F-26, G-42, J-10,

$\mathrm{K}-2, \mathrm{M}-23, \mathrm{M}-24, \mathrm{M}-28, \mathrm{M}-36, \mathrm{O}-2, \mathrm{P}-1, \mathrm{P}-12, \mathrm{P}-16$,

P-18, P-19, P-20, R-9, R-34, S-7, S-12, S-13, S-20, S-21, S-22,

S-36, T-3, V-2, W-10, W-11, W-12, W-15, W-17, W-19, W-28, W-29

barrier systems

markers

$A-2, A-3, C-1, P-16, P-20$

A-3

Index-22 
multiple barriers

rock barriers

soil barriers

vegetative cover

bitumen treatment

buried waste subsidence

cation exchange recovery

ceramic treatment

facility leakage

tank leak

geologic disposal

grout treatment

grout technology

grout treatment facility

injection system

integrated grout management plan

leachate from grout

phosphate/sulfate grout

site characterization

high-level waste (HLW)

microbial conversion of

ammonia

remedial effort

remedial action

remedial assessment

remedial plans

remedial studies

retrieval and processing

soil percolation (in situ)

sol-gel process

soil sorption (in situ)

special treatment

vitrification treatment

waste vitrification

plant (planned)

in situ vitrification

vitrification technology
S-22

C-8

F-2, F-3, F-4, L-6, W-11, W-12

C-1

S-7

P-18, W-11, W-12

W-15

S-7

R-53

H-3, S-22

S-7

C-11, P-19, R-9, S-12, S-14, T-3

A-16, C-11, H-19, K-2, S-54, T-3

P-19

R-36

$\mathrm{S}-12$

S-12, S-14

S-54

D-1

B-20

C-12, D-16, H-9, W-25

C-1, D-2, D-11, F-3, H-3, K-3, L-4, K-5,

K-12, M-34, M-36, R-32, R-33, R-34,

R-53, S-5, S-14, S-22, S-35, S-54,

$\mathrm{U}-24, \mathrm{~V}-1$

A-3, A-16, C-18, F-1, K-2, L-6, M-22,

M-28, N-15, R-9, R-35,

R-37, R-38, R-39, S-41

A-2, C-8, F-26, L-5, M-3, M-24, N-2,

O-1, P-12, P-16, P-17, S-12, T-3, W-11,

W-12, W-15, W-20, W-28, W-29

R-35, S-41

O-2, R-53, S-24

S-7

$\mathrm{L}-5, \mathrm{~S}-24, \mathrm{~V}-2$

W-28

S-7

G-42, M-28, N-15, O-1, S-13, W-29

F-26, G-42

F-1, F-26, N-15, O-1, P-12, S-13, W-29

Index-23 


$\begin{array}{cl}\text { waste storage tanks } & \mathrm{I}-1, \mathrm{~J}-4, \mathrm{M}-3, \mathrm{R}-5, \mathrm{~S}-41 \\ \text { rock dome concept } & \mathrm{R}-47 \\ \text { rock solubility in HLW } & \mathrm{R}-47 \\ \text { single-shell tanks (SST) } & \mathrm{D}-1, \mathrm{~K}-12, \mathrm{M}-34, \mathrm{M}-36, \\ & \mathrm{R}-47, \mathrm{R}-53 \\ \text { sludge retrieval } & \mathrm{M}-36 \\ \text { slurry growth } & \mathrm{J}-4 \\ \text { steel corrosion tests } & \mathrm{M}-3\end{array}$

Waste Disposal/Burial Sites

C-12, L-1, L-2, L-6, M-22, R-37, R-43, R-44, R-45, R-46, R-47, R-48, S-35, U-19, W-3, W-19

burial grounds

100 Areas burial grounds $\quad \mathrm{M}-26$

200 Areas burial grounds $\quad$ P-2, P-5, P-6, P-7, U-19

300 Area burial $\quad$ P-17

grounds

W-5 burial grounds $\quad V-1$

shallow land burial C-1, P-16

cribs

cribs (Hanford Site)

216-A-24 crib

W-19

A-2

216-A-36 B crib

W-20

216-S-1/2 crib

$\mathrm{V}-2$

216-Z-12 crib

316-A-36B crib

K-3, K-4, K-5,

$1325 \mathrm{~N}$ crib

B-20

J-10, O-2

ditches

Z-19 ditch

L-5

P-2, P-5, P-6, P-7, U-19

nonradioactive dangerous

waste landfill

ponds

$U$ Pond

183-H evaporation

basins

septic systems

L-5

P-2, P-5, P-6, P-7

trenches (liquid waste disposal facilities)

300 Area trenches

1301-N LWDF

S-3, S-5, U-19

1315-N LWDF

1325-N LWDF (new)

waste storage tanks

storage tanks (general) I-1, J-4, M-3, R-5, S-41

single-shell tanks (SST) D-1, K-12, M-34, M-35,

$M-36, Q-1, R-47, R-53$

wells

216-B-5 reverse well S-24

Index-24 
Waste Management

ALARA concept

(As Low as Reasonable

Achievable concept)

Allowable Residual

Contamination Level (ARCL)

alternatives assessment

BAT concept (Best

Available Technology)

bibliography (radioactive

waste management)

Monitored Retrievable

Storage Facility (MRSF)

Hanford Waste Management

Technology Plan (HWMTP)

hazard ranking system

hazardous waste

management

information and outreach program

packaging/storage

requirements

radioactive waste

management

regulatory compliance

release scenarios

technology change

waste management plan

W-17

$\mathrm{N}-2$

M-24, P-19, R-32, R-33, R-34, Q-1, $R-39, S-7, W-10$

W-17

P-1

C-6

U-10, U-20

B-1, S-35, U-2

B-1, K-12

W-20

S-36

A-4, C-6, F-1, F-2, F-3, F-4, G-25, $\mathrm{H}-3, \mathrm{H}-9, \mathrm{M}-1, \mathrm{M}-2, \mathrm{M}-22, \mathrm{M}-26, \mathrm{~N}-2$, $\mathrm{N}-15, \mathrm{O}-1, \mathrm{P}-16, \mathrm{P}-18, \mathrm{P}-20, \mathrm{Q}-1$, R-9, R-32, R-33, R-34, R-35, R-36, R-37, R-38, R-39, S-7, S-35, S-36, S-41, T-3, U-24, W-2, W-9, W-17, W-25

B-10, G-26, M-22, R-42, R-43, R-44, $\mathrm{R}-45, \mathrm{R}-46, \mathrm{~T}-2$

$\mathrm{Q}-1, \mathrm{~W}-2$

G-16

U-16, U-17, U-21, U-25 


\section{GEOLOGY AND HYDROLOGY}

\section{Aquifers}

aquifer communication

confined aquifer

contamination areas

Rattlesnake Ridge aquifer

surface recharge

unconfined aquifer

\section{Computer modes/codes}

computer modeling

solute transport model

UNSAT-H model (unsaturated flow, $H$ version)

UNSAT-2 model (unsaturated flow, two dimensional)

\section{Geohydrology}

arid sites

data collection

drilling technique

geohydrologic assessment

Geological Survey assessment

geothermal potential

mineral resources

identification

mineralology

socioeconomic value

monitoring wells

potable wells

stratigraphy

subsurface characteristics

well construction

\section{Geological Units}

basalt bedrock

basalt formations

Cold Creek Valley syncline

Columbia River basalt

Columbia River Plateau

Grand Ronde basalt

Hanford Formation

Pasco Basin

Rattlesnake Ridge interbed

Ringold Formation

Saddle Mt. basalt

G-28, J-9

E-10, G-28, M-35, S-31, V-3

G-28

G-28, J-9

G-11, G-13

F-22, G-27, G-28, M-29, S-39, U-29, V-3, Z-1

$J-12, K-8, M-29$, S-4, S-18

$\mathrm{K}-8, \mathrm{M}-29$

F-2, F-4, G-8

F-2

J-12, J-13, J-14

$\mathrm{R}-41$

D-17, L-7

F-22, G-11, G-15, L-7, S-4

$\mathrm{U}-29$

$\mathrm{M}-35$

$\mathrm{L}-13$

A-17, L-13

$\mathrm{L}-13$

C-9, L-7, M-21, M-30, M-31

$M-21$

L-7, M-37, T-1, V-3

A-17, B-11, G-14, G-28, M-35, S-51

$M-21, M-30$

G-24

A-17, G-14, G-15, M-37, V-3

M-37

T-1

S-4, V-3

S-40

$T-1$

G-14, G-43, J-11, M-35, W-30

S-39

T-1

D-17 
Umtanum flow

M-37

Wanapum basalt

D-17

Hanford Site (specific locations)

B Pond

BWIP site

data summary

Gable Mt. Pond

Hanford Reach

Hanford Site

Hanford Site wells

nonradioactive defense waste (NRDF) landfill

Rattlesnake Mt.

reference repository location (RRL)

PUREX Plant

Wye Barricade

200 Areas

\section{Hydrology}

borehole (dry wells) data

evaporation

evapotranspiration

ground water

(also see HANFORD

SITE)

chemical analyses

data base

drainage

flow rates

ground-water mounds

ground-water

movement

ground-water recharge

hydraulic conductivity

hydraulic gradient

hydrochemical data

information needs

shoreline springs

surface recharge

transmissivity

travel times

unsaturated flow

water balance
$J-9$

C-43 G-15

C-23

J-9, S-39

$M-29$

G-12, L-7, L-13, S-31, U-29, U-30

B-11, M-30

W-14

S-51

$M-37$

U-3

$\mathrm{H}-5$

D-17, G-27, G-28, J-9, K-9, R-52,

S-18, T-1, U-3, Z-1

B-11, S-40

C-3, J-12

G-11, G-43, K-9, K-11

C-9, E-8, E-10, E-11, E-16, G-27, G-43, M-11, M-30, S-31

S-31

G-15, M-30, S-4

G-13, J-13

F-22, G-27

G-27, Z-1

G-14, G-15, K-8, S-18, S-39, U-29,

$W-14$

G-8, G-24, G-43, K-11, R-52, S-51

C-3, G-14, G-27, S-18, S-39, S-40,

$W-14$

$J-9, V-3$

J-9, S-31, S-51

$\mathrm{K}-8$

$M-11$

G-13, G-24, G-43, S-51

S-40, W-14

F-22, G-27, U-29

$\mathrm{C}-3, \mathrm{~J}-12, \mathrm{~J}-13, \mathrm{~J}-14$

G-8, G-12, J-12 
water level changes water quality

\section{Lysimeter Use}

field Lysimeter Test Facility (FLTF)

lysimeter data

lysimeter facilities

lysimeter performance

\section{Seismology}

J-11, M-37, U-3, U-30

compression

deformation strain

geodetic network

ground motion

long-term surface changes regional historic earthquake predicted volcanic events response spectra surface features

\section{Soil Data, Hanford Site}

evaporation

precipitation effects

soil characteristics

soil drainage

soil moisture

soil water potential

surface recharge

unsaturated (vadose) zone
$Z-1$

G-27, M-30, S-31

K-9

G-8, R-52, W-3

G-12, K-10, W-3

G-8, K-9, K-10

U-30

$\mathrm{U}-30$

$\mathrm{U}-30$

$U-3$

W-30

$\mathrm{U}-3$

J-11

$\mathrm{U}-3$

W-30

G-13

G-13, G-24, G-43, J-13, K-11, S-51

C-3, H-5, W-3

$\mathrm{H}-5$

G-11, H-5, S-18

$\mathrm{J}-13, \mathrm{~J}-14$

G-11, G-13

G-8, G-11, G-12, G-13, H-6, J-13, $\mathrm{J}-14, \mathrm{~K}-11, \mathrm{~W}-3$ 


\section{HANFORD SITE}

\section{Emergency Situations}

contractor responsibilities

emergency preparedness

emergency response

plan (ERP)

mobile laboratory samples

nonradiological emergency

response

radiological emergency

response

response coordination

Uniform Dose

Assessment Center

(UDAC)
$\mathrm{H}-1$

$\mathrm{H}-1, \mathrm{P}-8$

$\mathrm{H}-1$

W-26

G-21, H-1

P-8, W-26

G-21

G-21

\section{Environmental Assessment}

A-27, D-5, D-10, E-10, L-3, L-18, M-27, N-9, N-12, N-13, N-14,

R-28, R-54, S-19, S-50, U-1, U-5, U-6, U-7, U-8, U-9, U-11, U-12 U-13,

$\mathrm{U}-14, \mathrm{U}-17, \mathrm{U}-23, \mathrm{U}-26$

animal populations

BWIP program

BWIP site

BWIP site critique

Cold Creek Valley

cooling water discharge

disposal to soil

environmental impact

statement (EIS)

fish entrainment (plume)

flood potential

R-28

B-5, U-26

A-27, E-10, S-19, U-7, U-9, U-14, U-23

M-4

S-19

$\mathrm{L}-3, \mathrm{~L}-18$

$\mathrm{U}-21$

$\mathrm{U}-4, \mathrm{U}-6, \mathrm{U}-8, \mathrm{U}-11, \mathrm{U}-17$

geohydrologic data (also see

(GEOLOGY AND

HYDROLOGY)

geologic repository

(conceptual)

grout disposal process

HGP operation

Hanford Reach

high-level radioactive

waste

impact models

inactive waste sites

low-level radioactive waste

mitigation

D-10, U-5

S-19

$\mathrm{M}-4, \mathrm{U}-7, \mathrm{U}-9, \mathrm{U}-14$

B-5, M-4, U-7, U-9, U-14

$\mathrm{U}-13$

D-10, L-3, N-8, S-17

D-5, D-10, L-3,

$\mathrm{N}-8, \mathrm{R}-28$

M-27, R-8, U-11, U-12, U-17

$\mathrm{N}$ Reactor operation

C-21

$\mathrm{U}-12$

$\mathrm{U}-13, \mathrm{U}-17$

U-23, U-26

$\mathrm{D}-5, \mathrm{D}-10, \mathrm{~N}-12, \mathrm{~N}-13, \mathrm{~N}-14, \mathrm{U}-5, \mathrm{U}-28$

Index-29 
overview

outfall diffuser design

public risk

PUREX/UO 3 startup

radionuclides

radionuclides from BWIP

radiation dose assessment

reactor decommissioning

reference repository location (RRL)

risk assessment

socioeconomic

thermal plume

thermal plume mixing

thermal plume temperature

316(a) demonstration

waste disposal

waste disposal alternatives

waste storage tanks

wildlife use

\section{Environmental Data}

arid-land sites

BWIP site

confined aquifer

data summary

effluents and emissions

generic information

geohydrological data

collection

ground water

ground-water data base

(GDB)

monitoring wells

NEPA characterization

new production reactor

polychlorinated biphenyls

pond sediment

potable wells

shoreline springs

site characterization

regulatory requirements

unconfined aquifer

wells

well construction
R-28

L-3, R-3, S-17

$\mathrm{H}-10, \mathrm{~J}-7$

S-50, U-6, U-8

E-13, E-14

B-5

E-13, E-14, J-7, M-27, S-44, S-48, S-49

K-5, K-6, K-7, U-1

E-10, U-7, U-9, U-14, U-23, U-26

$\mathrm{U}-18$

$\mathrm{U}-26$

D-10, L-18, N-13, N-14, N-15

D-5, S-17

D-5

$\mathrm{N}-9, \mathrm{U}-5$

R-54, U-21, U-13, U-27

$\mathrm{M}-27, \mathrm{U}-11$

$\mathrm{R}-8, \mathrm{U}-4$

R-28

R-54

$\mathrm{U}-23$

E-10

C-21

E-13, E-14, F-20, H-10, J-5, J-7, S-44, S- 48, S- 49

C-21, J-3, W-10

R-41

C-9, E-8, E-10, E-11, E-16, M-11, M-30 $\mathrm{M}-30$

C-9, M-21, M-30, M-31

C-21, J-3

W-10

R-29, R-30

R-29, R-30

$M-21$

$M-11$

C-21, P-9, U-7, U-9, U-12, U-18, U-23, U-26, W-4, W-10

C-21

$\mathrm{M}-30$

$M-21, M-30$

$M-21, M-30$ 


\section{Environmental Monitoring}

B-12, C-9, E-8, E-9, E-11, E-13, E-14, E-16, F-20, G-31, G-32, G-33,

G-34, G-35, G-37, G-38, G-39, G-40, G-41, H-10, J-1, J-2, J-5, J-6,

J-7, L-9, L-10, L-11, L-12, L-17, M-6, M-7, M-8, M-9, M-10, M-31, P-3,

P-4, P-9, P-22, P-24, P-29, P-30, P-33, R-29, S-11, S-28, S-29, S-30,

S-44, S-48, S-49, W-4, W-5, W-6, W-7, W-8, W-22, W-23, W-24

air quality

aquatic biota

drinking water

contaminated plume

food and farm products

ground water

(unconfined aquifer)

ground-water modeling Hanford Reach

hazardous materials

monitoring program

monitoring wells

nitrate

nonradioactive releases

overview

penetrating radiation

public dose estimates

(also see RADIOACTIVITY)

quality assurance

radioactivity

(also seo RADIOACTIVITY)

radioactive materials

river water

sampling schedule

soil and vegetation

surface water

tritium

unconfined aquifer
P-4, P-24, P-29, P-30, S-44, S-48, S-49

$W-5, W-6, W-7, W-8$

C-9, M-6, M-7, M-8, M-9, M-10, S-28,

S-29, S-30

$\mathrm{C}-10, \mathrm{C}-11, \mathrm{C}-13$

P-4, P-24, P-29, P-30, S-44, S-48, S-49

C-9, E-8, E-9, E-10, E-11, E-16, L-9,

L-10, L-11, L-12, M-6, M-7, M-8, M-9,

M-10, M-31, P-3, P-4, P-9, P-22, P-24,

P-29, P-30, S-11, S-28, S-29, S-30,

S-44, S-48, S-49, W-23, W-24

$M-31$

G-31, G-33, G-34, P-4, P-29, P-30,

S-44, S-48, S-49, W-4, W-5, W-6,

W-7, W-8, W-21

C-19, G-31, W-23

G-32, G-33, G-34, M-31, U-22,

U-23, W-4, W-24

C-9

E-8, E-9, E-11, M-11, P-22

F-20, J-5, J-7

G-31, G-32, G-34, G-35, P-33

P-4, P-29, P-30, S-44, S-48, S-49

P-4, P-24, P-29, P-30

P-33

C-9, E-8, E-9, E-10, E-11, E-13

E-14, E-16, F-20, G-32, G-33, G-34,

G-35, G-37, G-39, G-40, G-41, H-10, J-1, J-2, J-5, J-7, L-9, L-10, L-11, L-12, M-11,

P-4, P-24, P-29, P-30, S-11, S-44, S-48,

S-49, S-50, W-22, W-23

E-16, G-31

C-9, M-6, M-7, M-8, M-9, M-10, P-22,

S-28, S-29, S-30

B-12, J-6, P-9

P-4, P-24, P-29, P-30, S-44, S-48,

S-49, W-5, W-6, W-7, W-8

P-9

E-8, E-9, E-10, E-11, P-22

C-9, E-8, E-9, E-11 
water quality

well-water samples

well sampling evaluation

wildlife

WNP-2 operation

\section{Hanford Management}

alternatives assessment

contractor responsibilities

effluent and waste management

Hanford Environmental Management

Program (HEMP)

Hanford Waste

Management

Technology Plan

(HWMTP)

hazard ranking

system

permit application

risk at DOE facilities

waste management

plan

waste minimization

effort

planning document

radiation protection

ALARA - (As Low As

Reasonably Achievable)

BAT concept (Best

Available Technology)

radiation safety

program

safety training

reactor decommissioning

regulatory compliance
P-4, P-24, P-29, P-30, S-28, S-29,

S-30, S-44, S-48, S-49

L-9, L-10, L-11, L-12, L-17

$\mathrm{L}-17$

G-34, G-35, W-5, W-6, W-7, W-8

W-5, W-6, W-7, W-8

M-27, R-8, U-1, U-4, U-6, U-11, $\mathrm{U}-17, \mathrm{U}-21$

$H-1, W-18, W-24$

U-15, W-18

$\mathrm{U}-10, \mathrm{U}-20$

B-1, S-35, U-12

U-25

$\mathrm{U}-18$

U-16, U-17, U-21, U-25

$\mathrm{U}-27$

A-27, B-5, K-1, L-4, P-3, R-8, R-41, R-54, U-1, U-10, U-13, U-15, U-16, U-17, U-18, U-20, U-21, U-22, U-23, U-25, U-26, W-18

H-6

$W-17$

H-6

H-6

$\mathrm{K}-1, \mathrm{~K}-6, \mathrm{~K}-7, \mathrm{U}-1, \mathrm{U}-16$

E-13, E-14, K-6, K-7, P-4, P-24, P-29, P-30, S-11, S-44, S-48, S-49, U-12,

U-15, U-16, U-17, U-18, U-21, U-25,

U-27, W-18, W-22, W-23 
Hanford Reach, Columbia River cooling water discharge

ecological modeling

COLSTAT4 model

RIVER model

TEMPEST model

flow and temperature data

Hanford Reach

representative important species (RIS) of fish

shoreline springs

water-level fluctuations

water quality

$\mathrm{L}-18, \mathrm{~N}-9, \mathrm{~N}-12$,

$\mathrm{N}-13, \mathrm{~N}-14, \mathrm{R}-6, \mathrm{~S}-17, \mathrm{U}-28$

S-25

W-21

A-25

L-18

W-21

W-21

$\mathrm{N}-12, \mathrm{~N}-14, \mathrm{U}-5$

C-9, E-10, M-11

S-25

$M-6, M-7, M-8, M-9, M-10, P-30, W-5$, W-6, W-7, W-8

Onsite Locations and Facilities conceptual facilities

BWIP site

exploratory shaft geologic repository

reference containment facility reference repository location (RRL)

deactivated reactors

FFTF (Fast Flux Test Facility)

Gable Mt. Pond

HGP (Hanford Generating Project)

N Reactor

$100 \mathrm{~N}$ shoreline 183-H evaporation basins $1301-\mathrm{N}$ trench 1301-N LWDF pond ecosystems

PUREX Plant

$\mathrm{UO}_{3}$ Plant

WNP-2

waste disposal sites waste storage sites 100 Areas

B-5, E-10, L-4, M-4, R-41, U-22, U-23 L-4

L-4, M-4, R-43

R-54

$E-10, U-22, U-23$

G-37, G-38, G-39, G-40, G-41, J-1, J-2, $\mathrm{K}-1, \mathrm{~K}-6, \mathrm{~K}-7, \mathrm{U}-1$

C-9

R-30

L-3, N-9, R-6

F-20, G-37, G-38, G-39, G-40, G-41, $\mathrm{J}-1, \mathrm{~J}-2, \mathrm{~L}-18, \mathrm{~N}-12, \mathrm{~N}-13, \mathrm{~N}-14, \mathrm{U}-13$

G-37, G-38, G-39, G-40, G-41, J-1

P-3

$\mathrm{J}-1, \mathrm{~J}-2$

$J-1, J-2$

R-29

$\mathrm{U}-6, \mathrm{U}-8$

$\mathrm{U}-6, \mathrm{U}-8$

W-4, W-5, W-6, W-7, W-8

L-9, L-10, L-11, L-12, S-11, U-20

$M-31, U-10$

E-8, E-9, E-11, F-20, G-37, G-38, G-39, G-40, G-41, J-1, J-2, K-1, K-6, K-7, P-3, P-22, U-1

Index-33 


\section{Areas}

300 Area

400 Area

\section{Water Quality}

drinking water

fluoride

ground water

nitrate

river water

spring water

tritium
E-8, E-9, E-11, E-13, E-14, L-9, L-10, L-11, L-12, P-22, R-29, R-30, S-11, U-4, U-6, U-8, W-22, W-23

E-11

W-4, W-5, W-6, W-7, W-8

$M-6, M-7, M-8, M-9, M-10$

E-10

$M-6, M-7, M-8, M-9, M-10, M-30, P-22$

C-9, E-8, E-9, E-10, M-11,

$M-6, M-7, M-8, M-9, M-10, W-5, W-6, W-7$, W-8

$M-11$

C-9, E-8, E-9, E-10, E-11, M-11 


\section{RADIOACTIVITY (RADIATION)}

\section{Computer Models/Codes}

AlRDOS-EPA model A-1

ARRRG model

(aquatic pathways)

computer modeling

DACRIN model

N-6

DITTY model (dose integratedover 10,000 years)

FOOD model (terrestrial pathways)

KRONIC model

PABLM model (dose from food consumption)

PERCOL model (radionuclide transfer in soil)

ONSITE/MAXI model $\quad \mathrm{N}-4$

$\mathrm{M}-13, \mathrm{~N}-3, \mathrm{~N}-4, \mathrm{~N}-5, \mathrm{~N}-6$

A-1

N-5

A-1, N-6

A-1

J-8, N-3

\section{Emergency Response (see HANFORD SITE)}

\section{Environmental Monitoring}

airborne radioactivity

air and atmosphere

aquatic biota

atmospheric dispersion

bioaccumulation/

biotransport

biomonitoring

contaminated soil

environmental monitoring

Hanford Reach

Hanford Reach shoreline

Hanford Site (general)

Hanford Site emissions

historical review

offsite/onsite data

onsite operations

sagebrush

sampling technique

surface soil

terrestrial animals

vegetation

wildlife

$\mathrm{E}-12, \mathrm{M}-13, \mathrm{~T}-4$

S-45, S-46, S-47

C-23, D-9

M-13, P-23, P-25, P-26, R-20, S-52

C-23

D-9, E-6, P-23, R-20

S-54

C-17, G-28, J-8, P-25, P-26, P-29, P-34,

S-42, S-44, S-45, S-46, S-47, T-4

D-9

S.42

J-8, J-9, R-20, S-23, U-28, W-16, W-27

$\mathrm{M}-12, \mathrm{P}-25, \mathrm{P}-26, \mathrm{P}-27, \mathrm{~S}-26, \mathrm{~S}-45$,

S- 46, S-47

D-9, F-7, P-25, S-26, W-16

P-23, P-25, P-26, P-28, P-34

R-20, S-45, S-46, S-47, U-28

P-23

T-4

P-25, P-26, P-28, P-31, P-32, P-34,

R-20, S-45, S-46, S-47

E-5

P-28, P-34, S-45, S-46, S-47

P-28, S-45. S-46, S-47 
Exposure Assessment

dose from natural radiation

dosimetry technology

dosimetry program

(history)

onsite (Hanford) workers

offsite public

exposure assessment

exposure pathways

public monitoring

radiation dose estimates

risk assessment

urinalysis

whole body counts

penetrating dose

potential health effects

statistical analyses

$M-25$

F-17, F-18, F-19

W-27

F-17, F-18, F-19, G-17, G-18, G-19, G-20, W-27

S-26

$A-1, N-1, N-3, N-5, N-6$

S-43

A-1, C-19, J-8, M-12, M-13, N-1, N-4,

$\mathrm{N}-5, \mathrm{~N}-6, \mathrm{R}-42, \mathrm{R}-43, \mathrm{~S}-26$

G-18, G-19, G-20

S-43

S-43

S-45, S-46, S-47

F-7, G-17, G-18, G-19, G-20

G-17, G-18, G-19, G-20, J-8

Ground Water (also see GEOLOGY AND HYDROLOGY and HANFORD SITE)

background radiation

characteristics

L-8, S-23

ground-water transport

S-23

A-20, C-23, F-27, F-28, L-8, R-31, W-16

Physicochemical Properties (of Radionuclides)

adsorption

behavior in basalt

behavior in ground water

behavior in soil

complexation

distribution coefficients

( $k d$ values)

effects of complexants

effects of pressure

effects of temperature

effects of trace ions

ion exchange

ion exchange values

leachability

physicochemical properties (general)

redox potential (Eh)

soil sorption

solubility

sorption/desorption

A-19, D-12, D-13, G-10, R-48, R-49,

R-50, R-51

A-18, A-19, A-20, S-1

B-3, B-4

J-15, R-31, R-48, R-49, R-50, R-51

D-12, D-13, K-15

A-18, G-9, R-48, R-49, R-50, R-51, S-1

D-13

A-18, S-1

A-18, A-19, S-1

R-48, R-51

B-3, B-4

R-51

D-15, G-10

B-3, B-4, D-15, E-1, F-27, F-28,

G-10, J-15, L-8, R-31

B-3, B-4, E-1, S-1

D-14, E-1

D-13, D-14, E-1

A-20, B-3, B-4 
sorption equations

sorption isotherms

\section{Radionuclides}

radionuclides (general)

specific radionuclides

americium-241

carbon-14

cesium-137

cobalt -60

europium-152

iodine-129

iodine-131

krypton-85

plutonium

plutonium-239/240

selenium-75

strontium-85

strontium-90

tritium

uranium
R-50

S-1

B-3, B-4, D-12, D-13, D-14, E-1, F-27, F-28, G-9, L-8, P-27, R-31, R-50, R-51, S-1, S-23, S-45, S-46, S-47

$\mathrm{P}-32$

P-23

A-18, A-19, E-5, R-48, R-50, R-51, S-42, S-52

C-23, J-15, R-48, R-49, R-50, R-51, S-42

$\mathrm{S}-42$

P-28, R-20, U-28, W-16

R-21

T-4

D-15, E-12, P-31

P-31

A-20

R-48, R-51

C-23, E-5, G-10, R-50

E-16, G-10

A-19, E-16, P-34

\section{Radiation, General}

assessment

background (natural) radiation

data analysis

Hanford Site releases

C-17, M-12, N-1, N-3, N-4, N-5, N-6,

P-23, P-25, P-26, P-27, P-28, P-31,

P-32, P-34, R-20, S-42, S-43, S-52

$\mathrm{M}-25$

C-17

F-7, M-12, N-1, P-23, P-31, P-32, S-43,

$\mathrm{U}-28$

quality assurance

C-17

NRC waste sites

N-4

radiation data

F-7, M-12, M-25, P-25, U-28

radiation protection

radioecology

F-17, F-18, F-19, W-27

D-9

radionuclide concentrations $\quad \mathrm{P}-27$

radionuclide movement

G-10

surface monitoring

$M-25$

surveillance program

C-17

Radioactivity, Site-Specific (also see EFFLUENTS AND WASTES)

B Pond

216-Z-19 ditch

$1301 \mathrm{~N}$ trench
S-45, S-46, S-46

E-12

E-37 
Hanford Reach

PUREX Plant

shoreline "springs"

surface soil

unconfined aquifer

waste disposal ponds

100 Areas

200 Areas
D-9

P-23, P-32

$R-31$

G-9

W-16

E-5

F-27, F-28, G-37, G-38, G-39, G-40, G-41, R-31

D-12, D-13, D-14, D-15, E-5, E-12,

P-32, R-49, T-4

\section{Radioactive Waste (also see EFFLUENTS AND WASTES) \\ high-level waste (HLW) \\ remedial actions \\ waste stabilization \\ D-12, D-13, D-14, D-15, E-1 \\ $\mathrm{E}-12$ \\ $E-12$}


SOCIOECONOMICS

Archaeology and Culture

Archaeological inventory $\quad$ R-7

Archaeological resources $\quad$ R-7

Archaeological sites $\quad$ R-7

$\begin{array}{ll}\text { Recommendations } & \text { R-7 }\end{array}$

Cities and Counties

Benton-Franklin

metropolitan statistical area

Benton/Franklin counties

D-18, B-13

C-7, F-23, S-9, S-10

Socioeconomic Conditions

current conditions

demography

economy

employment

expenditures

housing

income

information needs

local transportation

$C-7, F-23, s-9$, S-10

population

revenues

services and facilities

C-10, F-23

B-13, C-7, D-18, F-25

D-18

C-7, C-10, D-18, F-24, F-25

C-10

B-13, C-10

C-7

B-13, C-7, F-23

C-10

D-18

C-10

F-23

taxes and fees

F-24

trends

C-10

work force

C-10, F-24, F-25

Socioeconomic Impacts (effects of) affected Indian tribes

BWIP

BWIP closure

$\mathrm{N}$-Reactor closure

Nuclear Waste Policy Act

amendments

potential socioeconomic effects

L-16, S-37, W-1

B-13, B-14, C-7, C-10, D-18, F-23,

F-25, L-15, N-7, S-33, S-37, W-1

F-24

S-9, S-10

F-24

C-10, P-10, S-9, S-10

\section{Population Data}

\section{Benton-Franklin Counties}

mitigation strategies

population distribution

S-27

C-11

C-7, S-27 
population estimates

80-km radius

$S-27, Y-1$

population forecast

$S-27, Y-1$

Public Viewpoints BWIP

project interactions

$\mathrm{L}-15, \mathrm{~S}-33$

public information

$S-33$

risk perception

S-33

$\mathrm{L}-15, \mathrm{~N}-7$

Indian Nations (Native Americans)

cultural values

ethnohistoric data

W-1

federal Indian policy

L-16

Native Americans

L-16

Nez Perce Tribe

W-1

relation to BWIP

S-37

social and economic status

L-16

Yakima Tribes and Bands

S-37

Umatilla Tribes

S-37

S-37

Socioeconomics (general)

community interviews

B-14

data sources

B-14

data summary

C-21

mineral resources

L-13

monitoring

B-14 


\section{TERRESTRIAL ECOLOGY}

\section{Animai Documentation}

B-16, F-11, F-14, G-4, R-16, R-18

amphibians

M-5

birds

B-17

reptiles

small mammals/rodents

$\mathrm{F}-11, \mathrm{M}-5$

M-5

\section{Animal Community Characteristics}

behavior

burrowing

community composition

daily movement

disease

ecological relations

egg composition

food and feeding

habitat use

hatching success

historical documentation

home range

offsite movement

population density

population increase

mortality/survival

nesting

predation

relative abundance

reproduction

seasonal distribution

thermoregulation

trace elements (in eggs)
B-16, D-19, E-2, E-6, E-7, F-8, F-9, F-10, G-3, G-5, M-15, M-16, P-21, S-6, S-32

G-2, G-7

R-38

S-32

F-12

$M-15, M-16, M-17, M-20, R-22, S-34$

R-15

F-8, F-16, M-15, M-17, R-39, R-40, $\mathrm{U}-2$

B-16, E-2, E-6, E-7, F-8, F-9, F-11, F-14, G-3, G-4, G-5, G-6, G-7, M-5, $M-15, M-16, M-17, M-20, P-21, R-16$, R-18, R-38, S-6, S-15, W-13

E-2, F-16

$\mathrm{M}-14$

E-7, M-16, P-21, S-32

E-6

G-3, G-5, H-4, M-18, S-6

$M-16, M-18, R-1$

$\mathrm{E}-2, \mathrm{M}-18, \mathrm{~S}-34$

E-2, F-8, F-9, F-10, F-13, F-14, F-16,

$P-21, W-13$

F-13, S-34

F-9, G-6, M-5, R-38

D-19, F-8, F-13, F-16, H-4, M-18,

$M-20, P-21, S-6$

S-15

M-15

R-15

\section{Birds}

non-game birds raven -

S-6

Corvus corax

gulls - Larussspp.

F-9, F-10

$W-13$

raptors (birds of prey) 
hawks (general)

owls (general)

raptors (general)

red-tailed hawk Buteo jamaicensis

Swainson's hawk

waterfowl Buteo swainsoni

American coot

Fulica americana

Canada geese

Branta canadensis

mallard ducks

\section{Game Animals}

coyote -

Canis latrans

elk -

Cervus elaphus

mule deer-

Odocoileus hemionus

Impact Assessment (effects of)

burning

clipping

drought

elevation

grazing

human activity

offroad vehicles

plowing

predation

precipitation

public exclusion

radioactivity

recovery process

slope

water-level fluctuations

waste burial sites

wildfire

\section{Insects}

ants

darkling beetles

harvester ant

Pogonomyrmex owyheei

tenebrionid beetles
F-14

F-14

C-2, F-8, F-9, F-14

$F-10, F-12$

F-8, F-10, P-21

F-16

E-2, E-3, F-13, R-15

E-4

S-32, S-34

$M-14, M-15, M-16, M-17, M-18$,

M-19, M-20, P-15, R-1

E-4, E-6, E-7, R-24, S-34, U-2

M-23, R-13, R-24, R-25

$M-23$

R-24, R-27

$\mathrm{R}-12$

R-11, R-14, R-25

F-9, F-10, P-21

R-13

R-23

F-13

D-19

R-18, R-21

$\mathrm{H}-4$

R-14, R-25

R-26

R-18

H-4

R-19

G-3, G-5

R-38, R-40

G-2

S-15 
Methods in Terrestrial Ecology

biomonitoring

automatic recording

C-2, E-4, E-6, E-7

capture technique

P-15

immobilization

E-3

$\mathrm{M}-19$

radiotelemetry

E-4, P-15

Plant Documentation

forage plants

plant community

plant documentation

riparian plants

R-11, R-38, U-2

K-13, R-13, R-17, R-25

$\mathrm{R}-16$

R-14, R-16

Plants, Specific

big sagebrush -

Artemisia tridentata

bitterbrush -

Purshia tridentata

bluebunch wheatgrass -

Agropyron spicatum

cheatgrass -

Bromus tectorum

filaree -

Erodium cicutarium

greasewood -

Sarcobatus vermiculatus

Indian ricegrass -

Oryzopsis hymenoides

Sandberg's bluegrass -

Poa sandbergii

Siberian wheatgrass -

Agropyron sibiricum

spiny hopsage -

Grayia spinosa

thickspike wheatgrass -

Agropyron dasytachyum

willows - Salix spp.

yellowcress -

Rorippa columbiae

R-10, R-11, R-17, R-24

R-24

M-23, R-10, R-11

R-12, R-23, R-26

R-23

R-19

F-29

F-29

F-29

R-19

F-29

R-14

S-2

Plant Community Characteristics

community production

ecological relations

litterfall

R-10, R-11, R-12, R-24, R-25, R-26, R-27

phytomass

plant colonization

plant production

recovery

R-22

R-27

$\mathrm{R}-10$

R-21, R-23

$M-23$

$\mathrm{R}-23$

Index-43 
revegetation

rooting depth

reclamation

species composition

trace elements (in leaves)

Radioecology

C-2, E-6, F-16, G-2, U-2

bioaccumulation

biomonitoring

biotransfer

Rodents, Small Mammals, Great Basin pocket mouse

Perognathus parvus

reptiles (general)

rodents and small mammals (general)

Townsend ground squirrel Spermophilus townsendii

Species Under Risk

endangered species

Specific Terrestrial Ecosystems

ALE Reserve

B-C crib

BWIP site

Cold Creek Valley

Columbia Basin

Gable Mt. Pond

Hanford Site

overview

riparian areas

B Pond

Gable Mt. Pond

Hanford Reach

onsite ponds

(200 Areas)

Rattlesnake Springs

Snively . Creek

(Snively Springs)

shrub-steppe ecosystem

waste burial sites
F-29, R-25

$\mathrm{K}-13$

F-29, R-21, R-26

R-13, R-19

R-17

$\mathrm{U}-2$

C-2, R-15

G-2

and Reptiles

D-19, G-6, H-4

F-11

G-4, G-6, G-7

R-39

S-2

$D-19, M-15, M-16, M-17, M-18, M-20$,

R-1, R-17

$\mathrm{U}-2$

F-11, M-5, R-13, R-25, S-6

R-25

$\mathrm{M}-14$

$\mathrm{C}-24$

F-9, F-10, F-14, F-29, R-21, R-22, R-24, R-27, S-15, S-32

R-18, R-22

U-2

R-16, U-2

F-13, R-15, R-18, S-2, W-12

E-6

C-22, C-26, C-28, G-1, R-14

C-20, G-1

R-10, R-11, R-12, R-21, R-22, R-23,

R-39, R-40

G-2, G-7, H-4, K-13 


\section{DISTRIBUTION}

No. of

Coples

OFF SITE

10 DOE/Office of Scientific and

Technical Information

\section{ON SITE}

\section{DOE RIchland Operatlons Offlce}

R. F. Brich

P. F. X. Dunigan

R. A. Holten

R. D. Izatt

J. J. Keating

M. J. Lawrence

M. J. Plahuta

A. J. Rizzo

J. J. Sutey

M. W. Tiernan (10)

K. J. Wheeless

J. D. White

DOE Public Document Reading Room (2)

1 Hanford Environmental Health

Foundation

L. J. Maas

2 Westinghouse Hanford Company

G. D. Carpenter

J. J. Dorian

1 Kaiser Engineers Hanford

W. H. Bodily

172 Paciflc Northwest Laboratory

R. L. Aaberg

L. L. Ames
No. of

Coples

G. L. Anderson

G. L. Andrews

W. J. Bair

D. J. Bates

C.D. Becker (30)

L. L. Belt

L. E. Bisping

F. P. Brauer

T. L. Brown

R. W. Bryce

J. W. Buck

L. L. Cadwell

D. B. Cearlock

J. C. Chatters

C. E. Cushing

D. R. Dahl

D. S. Daly

D. D. Dauble

D. I. Dennison

D. L. Dickison

R. L. Dirkes

L. E. Eberhardt

C. E. Elderkin

J. C. Evans

J. W. Falco

M. J. Fayer

D. H. Fickeisen

R. E. Fitzner

J. J. Fix

M. D. Freshley

J. S. Fruchter

R. M. Fruland

W. E. Gaines

G. W. Gee

E. S. Gilbert

C. S. Glantz

R. E. Gephart

R. O. Gilbert

M. J. Graham

R. H. Gray (20)

H. A. Haerer

J. M. Hales 
No. of

Coples

R. W. Hanf

M. S. Hanson

P. C. Hays

P. R. Heller

D. P. Higby

K. A. Higley

E. L. Hilty

D. J. Hoitink

J. R. Houston

T. W. Horst

J. D. Jamison

R. E. Jaquish

E. J. Jensen

J. R. Johnson

T. L. Jones

J. L. Julya

C. T. Kincaid

R. R. Kirkham

K. J. Klingler

W. W. Laity

G. V. Last

T. L. Liikala

E. W. Lusty

D. L. Mackliet

J. A. Maclellan

W. D. McCormack

V. L. McGhan

T. J. McLaughlin

$P$. J. Mellinger

D. L. Merrill

P. J. Mitchell

J. Mishima

S. B. Moore

B. A. Napier

D. A. Neitzel

T. A. Nelson

W. L. Nicholson

K. B. Olsen
No. of

Coples

K. R. Oster

T. L. Page

K. R. Price

L. L. Rader

J. V. Ramsdell

L. A. Rathbun

W. H. Rickard

J. T. Rieger

R. G. Riley

D. E. Robertson

J. V. Robinson

L. E. Rogers

R. Schalla

R. G. Schreckhise

R. J. Serne

G. H. Sewart

D. R. Sherwood

C. S. Simmons

R. L. Skaggs

R. M. Smith

J. K. Soldat

A. K. Stalker

J. B. States

S. L. Stein

J. A. Stottlemyre

M. J. Sula

S. L. Sutter

W. L. Templeton

J.M. Thomas

R. W. Wallace

W. J. Waugh

S.G. Weiss

R. E. Wildung

W. R. Wiley

R. K. Woodruff

Historical File-R. K. Woodruff

Publishing Coordination

Technical Report Files (5) 